Historic, Archive Document

Do not assume content reflects current scientific knowledge, policies, or practices. 



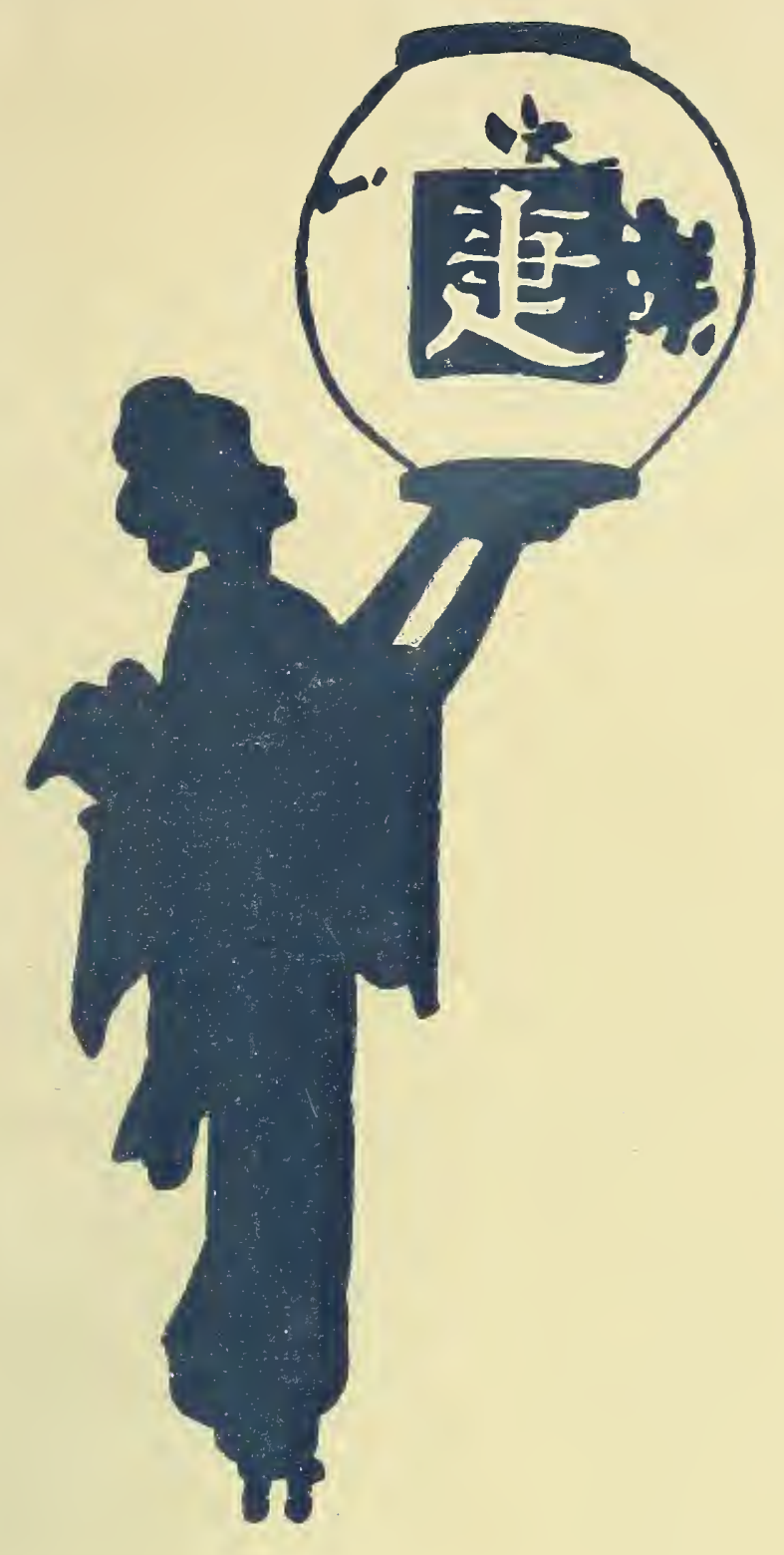

\section{Sprinty \\ (batariden \\ 西inak \\ 1910}

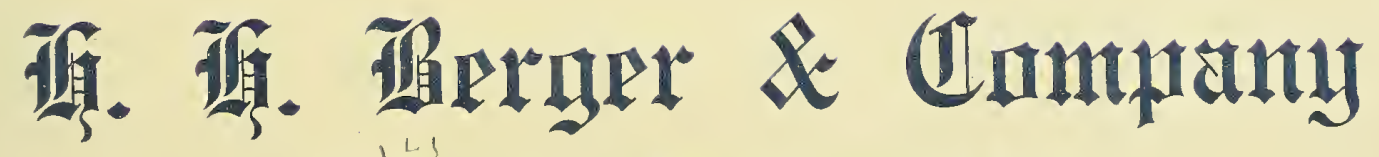

ZII 現arren Strept, Ainu Jark 


\section{WAR TIMES ALL BRANCHES OF INDUSTRY TO WIN THE WAR}

We present to our friends and eustomers this year only a Simple List of such Seeds, Bulbs, etc., as we have to offer in our well known usual good quality, in this, our

\section{1st YEAR OF BUSINESS EXISTENGE}

Paper has been steadily advancing, printing costs double what it did some time ago and therefore we have eliminated unneeessary illustrations, such as most vegetables, feeling assured that all who read this booklet and are interested in the eultivation of vegetables, need no pietures of Beets, Beans, Carrots, ete., to realize the value of Good Seed. We thus effect a material saving which we will apply to the super-exeellent quality of our seeds.

\section{"PLEASE READ CAREFULLY THE FOLLOWING"}

SEEDS AND BULBS-FREE DELIVERY TERMS. We deliver all seeds and bulbs free anywhere in the Tnited States, at prices named in this catalogue if cash accompanies the order, by pareel post, express, or freight. at our option. Note.- We do not prepay on miscellaneous garden supplies, as Implements, Fertilizers, Inserticides, Grass Seeds, Bamboo Stakes, Roots, Plants, Valley Clumps, or Peas, Beans, or Corn, exeept in paekets. On Peas, Beans and Corn, postage must be added. One pint weighs one pound; one quart, two pounds.

REMITTANCES should be made by draft on bank, Post Office or Express Money Order. (Registered letter where cash is enelosed). Small sums may be sent in loose postage stamps. When personal eheeks are sent please arld 10 cts. for exchange.

ACCOUNTS. Should you wish to open an aeeount please send us referenees. No account will be opened under \$5.00. No goods can be sent out to parties unknown to us-unless order is aceompanied by eash.

NON-WARRANTY. H. H. Berger \& Co., Inc., give no warranty, express or implied, as to deseription, quality, produetiveness, or any other matter of any seeds, bulbs or plants they send out, and will not be responsible for the erop. If the purehaser does not aecept the goods on these terms they are at onee to he returned. ILI, claims must be made within 5 days after receipt of goods.

\section{IMPORTANT}

Owing to the war, prohibition of exports and imports, and difficulty of transport, we expeet some shortages in our crops. All offers are, therefore, made subject to delays in delivery beyond our eontrol. To secure your requirements it is advisable to ORDER EARLY. For the same reasons, prices are subject to ehange.

Our Telephone number is Barclay 5930.

\section{H. H. BERGER \& CO., Inc.}

Telephone: 5930 BARCLAY

70 Warren Street, New York

\section{N D E X}

VEGETABLES FLOWER SEEDS

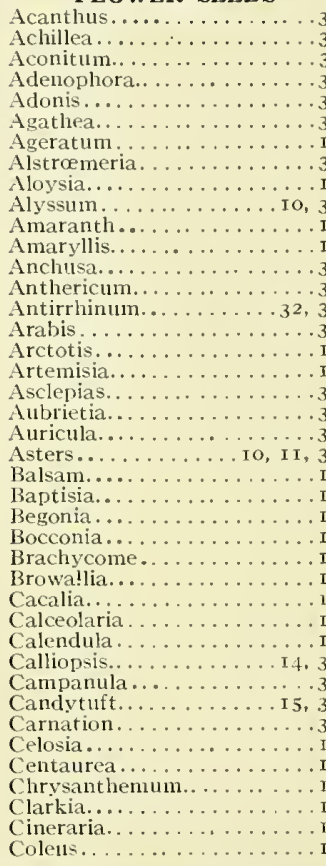

\begin{tabular}{|c|c|}
\hline Page & Linaria. \\
\hline 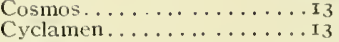 & $\begin{array}{l}\text { Linaria. } \\
\text { Linum. }\end{array}$ \\
\hline Dahlia............. 34,35 & \\
\hline$\ldots \ldots \ldots \ldots 34$ & \\
\hline$\ldots \ldots \ldots \ldots 35$ & Malva.... \\
\hline Dianthus............ 34. 35 & \\
\hline ictamnus...............3.35 & $\begin{array}{l}\text { arshmallow.. } \\
\text { arvel Peru... }\end{array}$ \\
\hline 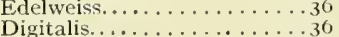 & caria.... \\
\hline Dimorphoteca...........35 & Iat thiola. \\
\hline Erigeron.................36 & \\
\hline & orning Glories....... \\
\hline tzia.... & Myosotis............... \\
\hline sia $\ldots \ldots \ldots \ldots \ldots \ldots 3 \mathrm{I}$ & Nemophylla............ \\
\hline Gaillardia............ 8,36 & \\
\hline ..............36 & \\
\hline$\ldots \ldots \ldots \ldots \ldots 3 \mathrm{I}$ & a. \\
\hline & \\
\hline$\ldots \ldots \ldots \ldots 3^{6}$ & ital Grasses... \\
\hline$\ldots \ldots \ldots \ldots$ I 8 & ........... \\
\hline ..... I9 & non.. \\
\hline$\ldots \ldots \ldots \ldots$ I8 & unia. \\
\hline & \\
\hline ......3I & \\
\hline ila........... 18,37 & \\
\hline$\ldots \ldots \ldots \ldots \ldots, \ldots 37$ & \\
\hline$\ldots 18,37$ & \\
\hline $1 \ldots \ldots \ldots \ldots 37$ & \\
\hline ..........37 & \\
\hline .37 & \\
\hline .. 19 & \\
\hline & \\
\hline .37 & \\
\hline & \\
\hline ..37 & \\
\hline & \\
\hline ..... I9 & \\
\hline$\cdots \cdot 4^{2}$ & \\
\hline & \\
\hline & \\
\hline …1 19,39 & \\
\hline athyrus................39 & ing \\
\hline
\end{tabular}

Page

Virginian Stocks..............28 Wallflower.............28

Whitlavia .............28

Zinnia................20 BULBS and ROOTS

Acidanthera ............5 6

Arapanthus..................44

Amaryllis...................44

Anaryllis.................

Anemone.................44

Bessera....................44

Calla.................. 45

Cannas..............63

Clilidanthus ............45

Cooperia...............56

Crinum . . . . . . . . . . 45

Dahlia...............46

Dielytra...................49

Eremurus ............. 49

Funkia................ . 56

Hyacinthus candicans.......

Iris.................. 50, 5 I

Ismene.......................

Ismene..................

Lilies...........52,53,54

Montbretia................5

Oxalis... . . . . . . . . . .

Peonia.................55

Tigridia .............. 56

Trilliım.................56

Tritoma...............56

Watsonia..............56

Zephyranthes............56

PERENNIAL PLANTS

Pages.......57 to 62 VINES and CLIMBING PLANTS

Page.................6.63

Bamboo stakes, Insecticides and Fertilizers.. 


\section{NOVELTIES}

ASTER SAPPORO QUEEN (Japanese Novelty). A magnificent strain attaining a height of 2 to $3 \mathrm{ft}$. Flowers superb with whorls of twisted petals resembling Cactus Dahlias. Unexcelled for cut flowers. A glorious show in your garden. In widest range of colors. Pkt., 25 cts. blue tint and shaped like ative of Texas; of the rare and glorious gent the blooms remaining fresh for days after cutting. Sow the seeds early indoors and transplant when danger of frost is past. Trial pkt., 10 cts.; pkt., 25 cts.

ZINNIA ELEGANS "ACHIEVEMENT." Distinct from all other, on account of Zinnias hitherto raised the shape of its petals which are on account of Zinnias hitherto raised the shape of its petals which are partly tubular at the base and expand in a cactus-like form toward the
tip, thereby displaying a rich variety of color, running through rose, salmon, lilac, scarlet and copper. The reverse side of the petals are lilac, varying from light to dark. It is a rare and beautiful color combination never before seen among Zinnias. The plant is a free strong grower, producing an abundance of very double flowers on stalks borne well clear of the foliage. The blooms often attain a diameter of 5 to 6 ins. An ideal acquisition for the garden. Trial pkts, 10 ets.; plt., 25 cts. ORNING GLORY DOUBLE SNOW-FAIRY. The plant is very vigorous, of ten attaining a height of $\mathrm{r} 2$ or more fect. The flowers appear in the purity and the quaintness of its blossoms which are pure white in the purity and the quaintness of its blossoms which are pure white and curiously
pkt., 25 ets.

\section{The New Giant Japan Morning Glories in Patriotic Colors \\ HINO-KOROMO. Vivid scarlet.}

UIJINOMINE. An immense snow white.

MIKASA YAMA. Light blue.

These flowers are True Giants, often attaining 6 ins. in diameter. Grand and Gorgeous Prize Takers. They love rich soil and sunshine. Trial pkt., 5 cts.: large pkts, 10 ets.; the three for 25 cts.

KAKUREMINO (The Unique Japan Morning Glory). Of the densest, most velvety black, with a white margin like a great Brazilian Butterfly. Small pkt., 10 cts.; plt., 25 cts.

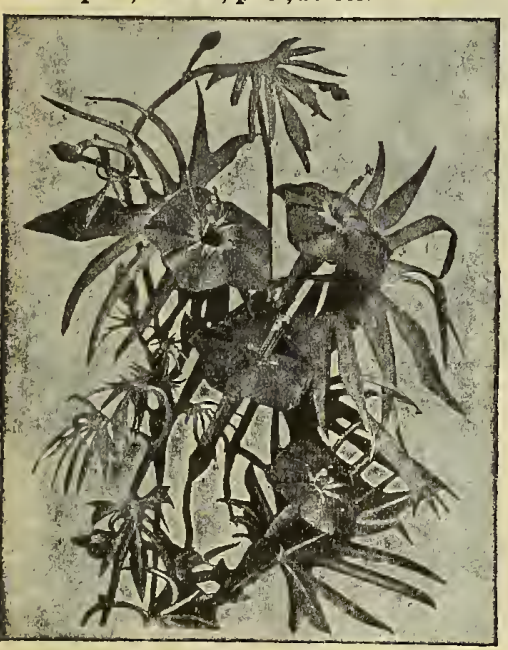

Ipomoea Cardinalis
IPOMOEA CARDIN : ALIS (The Cardinal Climber). The most bcautiful and brilliant It is a strong and rapid grower, attaining a height of $20 \mathrm{ft}$. or more, with beautiful, fernlike, laciniated foliage and literally covered with a blaze of circular fiery cardinal red flowers from mid-summer till frost. The flowers are about $I^{1}$ ins. in diameter, and are borne in clusters of five to seven blossoms each, and wherever it ha been grown has attrac ted more attention and favorable comment than any other plant in the garden. Delights in a warm, sunny situation and good soil. Trial pkt., 10 cts.; pkt., 25 cts.

"DOROTHY." Brilliant rose, identical with the well known rose "Dorothy Perkins." Flowers rich profusion. Trial pkt., 10 cts.; pkt., 25 cts. SCHIZANTHUS RETUSUS "PINK BEAUTY." shade of rose pink, clear as satin without any marking or shading. Flowers are of good substance, lasting a long time and are superb for table decoration. Trial pkt., 10 cts.; pkt., 25 cts.

EW DOUBLE FLOWERING COSMós. One of the most beautifu and useful of Autumn flowers. These new double sorts are marvel-
lously attractive, with beautifully frilled and fluted petals, and are unsurpassed for cut flower purposes.

WHIE SWA. Snowy white.

RED BEAUTY. Rich deep red.

MIXED. Trial pkt., 10 cts.; Iarge pkt., 25 cts.

IMPROVED COSMOS SULPHUREA. The plants are identical in bearing; the delicate lacy foliage of all Cosmos. It grows to a height of 20 to 24 ins. with an unlimited number of branches, simply smothered in the brilliant golden yellow flowers. Blooms from August till early frosts. Easy to cultivate, and exquisite for decoration, lasting a long time in water. Trial pkt., 5 cts.; pkt., 10 cts., large pkt., 25 cts.

ARABIS ALPINA. Every flower lover knows the Arabis Alpina that lovely Spring blossom which forms edges or beds of a snowy white at a time when the first flowers appear. From "La Belle France" is now sent to us a most beautiful Novelty, a floral paradox, an Arabis covered with large bright rose flowers varying from tender pink to bright carmine. It has received an award-of-Merit in France and merits all that can be said of it. Of vigorous growth, easy to cultivate, it is well worth the growing. Trial pkt., 10 ets.; pkt., 25 ets.

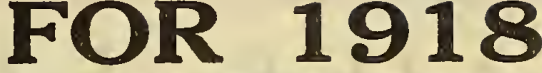

TANGO FLOWER or "F R A GRANCE OF THE SOUTH. This exquisite flower is found on the high table lands or mesas of Central Mexico and Peru. Its pure and chaste sweetness, detle fragrance, are indescribable. The senoritas twine these starry blossoms in their dusky tresses, corsage with them for the dance. The bulbs can be planted a soon as dange $r$ of frost is over, and will bloom in four to six weeks. The hallest bulb will bloom. Each bulb ground will form bulblets, each of which sends up a flower stalk, thus, keeping up one mass of bloom

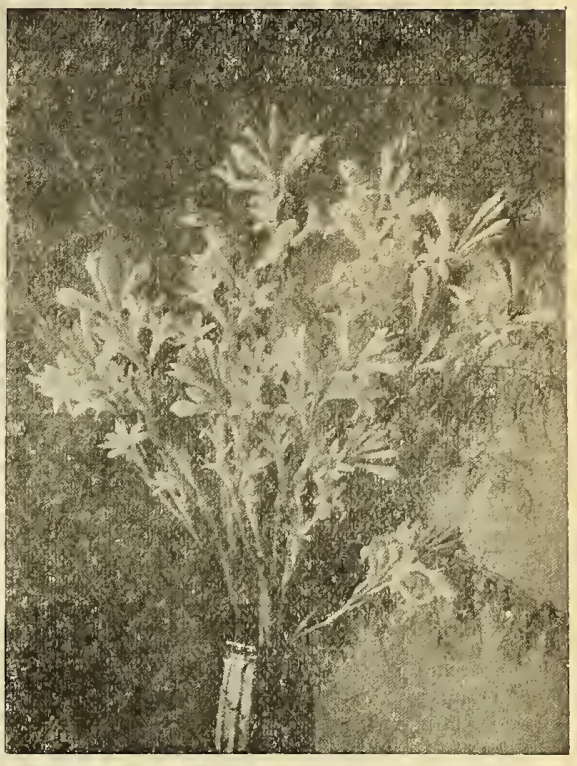

from early summer till frost cuts them down. The flowers appear from ten to twenty to each stalk, are snowy white, star-like, petals thick, like wax, filling with the fragrance they exhale their surroundings. If cut when the first flowers open and placed in water they will continue to bloom for ten days to two weeks. The stems are tall and stiff, withstanding high winds and all sorts of weather, but must be lifted
frost sets in and stored the same as Gladioli, Dahlias or Amaryllis.

rost sets in and stored the same as Gladioli, Dahlias or Amaryllis. 100

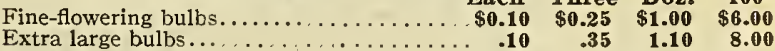

\section{NOVELTY DWARF FRENCH BEAN}

This is a marvel of quick growth, earliness and general value. It is one of the heaviest croppers yet introduced. It produces masses of medium sized, rich green fleshy pods which are very crisp and practically Stringless.

This new French Bean is very dwarf, with dark green foliage, and of remarkably quick growth,

This bean being as yet quite scarce we would urge our Customers to order early. Trial pkt., 10 ets.; Iarge pkt., 25 cts.

CHINESE WOOLFLOWER. This is a unique form of the feathered Cockscomb, growing two to three $\mathrm{ft}$. high, each branch terminated with a large head of rich crimson flowers that look as if made out of some silkywool material. Not only effective in beds or borders but highly inter-

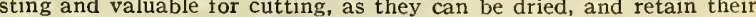
bright color for weeks. Pkt., 10 cts.; 3 pkts., 25 cts.

NEW ORIENTAL POPPY. Enormous flowers, pure satiny white with large blotch at the base of each petal, unquestionably the most important addition to the list of hardy perennial seeds for the season of I9r 8 . Like most hybrids, the seedlings are liable to vary somewhat, but a pkt., 10 ets.; pkt., 25 cts.

\section{HYBRIDIZED POTATO SEED}

\section{It is from these that ALL} valuable new varieties of Potatoes are produced. Millions have never seen a Potato Seed Ball. Thousands have tried in vain to get the seed. Now is your opportunity. This unrivaled seed will produce an endless variety of new kinds. Growing new and distinct Seedling Potatoes is intensely interesting. They will be the greatest curiosity of your garden. This seed will positively produce innumerable new kinds, colors shapes, sizes and qualities. The product will astonish you. Everybody should plant a few packets. Trial pkt., 10 cts.; Iarge pkt.,

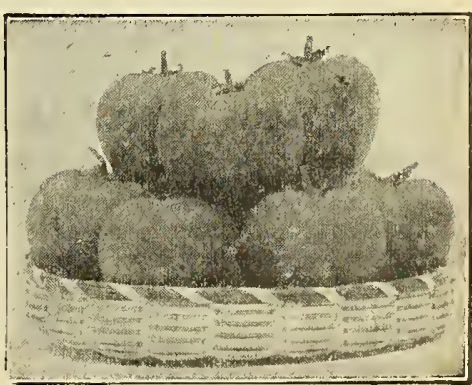

Potato Seed Balls-One-third Size
"Plant potato eyes and you get potatoes like the parents, but plant potato seeds and you tap a mine of heredity, infinite in its uncertainty, but infinite too in its possibility. These rare seeds produce remarkable variations all unlike any potato which has ever been cultivated.' 


\section{ASPARAGUS SEEDS}

One ounce for 50 feet of drill.

CONOVER'S COLOSSAL. Mammoth variety. Standard sort. One , of the best. Plst., 10 cts.; $1 / 4$ b., 30 cts.

PALMETTO. Southern origin. Early. Very prolific. Pkt., 5 ets.; t. oz., 10 ets.; $1 / 4$ lb., 30 ets.

\section{ARTICHOKE}

One ounce produces 500 plants

A delicious vegetable. The heads are boiled and the bottom of each scale eaten with butter andisalt or mayonnaise dressing.

FRENCH GLOBE. Standard sort. Pkt., 10 ets.; oz., $\$ 1.00$.

JERUSALEM ARTICHOKE. Edible tubers easy of cultivation. Cut and planted like Potatoes. Used for pickling and boiling, feeding stock, etc. Qt., 25 cts.

\section{BEANS}

Packets of all varieties Is cts., postpaid. If wanted by parcel post add postage at zone rates. To points East of Mississippi River add 7 cts. per pound. To points West of Mississippi River add I 2 cts, per pound.

$$
\text { One pound will plant } 50 \text { feet of drill }
$$

Wax Beans are scarce.

Green Podded Beans are the best for the home garden.

GIANT STRINGLESS GREEN POD. One of the earliest. Pods round, very crisp and tender. Lb., 45 cts.; 2 lbs., 80 cts.

BOUNTIFUL or IMPROVED YELLOW SIX WEEKS. A prolific bearer. Early flat podded sort, perfectly stringless, very tender; also fine for late sowing. Lb., 45 cts.; 2 lbs., 80 ets.

LONGFELLOW. Extra early round podded sort. Fleshy and tender ; delicious when cooked, and unexcelled for Home use. Lb., 40 cts.; 2 lbs., 70 ets.

IMPROVED EARLY RED VALENTINE. Erect, strong growing vines, and one of the very earliest. Pods round and tender. Will germinate in cold ground when other sorts will not. Lb., 40 cts.; 2 1bs., 70 cts.

BLACK VALENTINE. Not quite as early as Red Valentine, but well suited to a succession of plantings. Pods are long, growing in great clusters, straight and round. Few beans are greater yielders. Lb., 45 cts.; 2 lbs., 80 cts.

REFUGEE 1000 to 1. One of the latest Beans. Pods are 5 ins. long tapering to a slender point. Fleshy, brittle and mild in flavor. Lb., 40 cts., 2 lbs., 70 cts.

REFUGEE EXTRA EARIY. Similar to above. Ripens two weeks earlier. Lb., 40 cts.; 2 lbs., 70 cts.

\section{DWARF or BUSH BEANS}

DAVIS WAX. Very productive rustless sort. Pods 6 to 7 ins. long, light yellow, straight and handsome. Crisp and tender. Seed medium large, kidney shaped, clear white. Excellent for baking.

NEW KIDNEY WAX. A most desirable sort. Produces a heavy crop of waxy succulent pods; long, flat and not liable to rust. Lb., $\mathbf{5 5}$ cts.; 2 lbs., $\$ 1.00$.

BRITTLE WAX. Earliest of all Wax Beans. A great cropper. Pods long; fleshy; entirely stringless. White seeded and if allowed to fully ripen make excellent shell beans. Lb., 50 cts.; 2 lbs., 90 cts.

STRINGLESS WHITE WAX. Round straight pods; bright lemon color; brittle, meaty, and entirely stringless. Desirable for home garden Lb., 55 cts.; 2 lbs., \$1.00.

IMPROVED BLACK WAX. Splendid for home garden. Bushy vines with round pods 6 to 7 ins. long. Golden yellow color. Early. Lb. 50 cts.; 2 lbs., 90 ets.

IMPROVED GOLDEN WAX. An early, hardy, robust grower. Can be sown any time to early Fall. Lb., 50 cts.; 2 lbs., 90 ets.

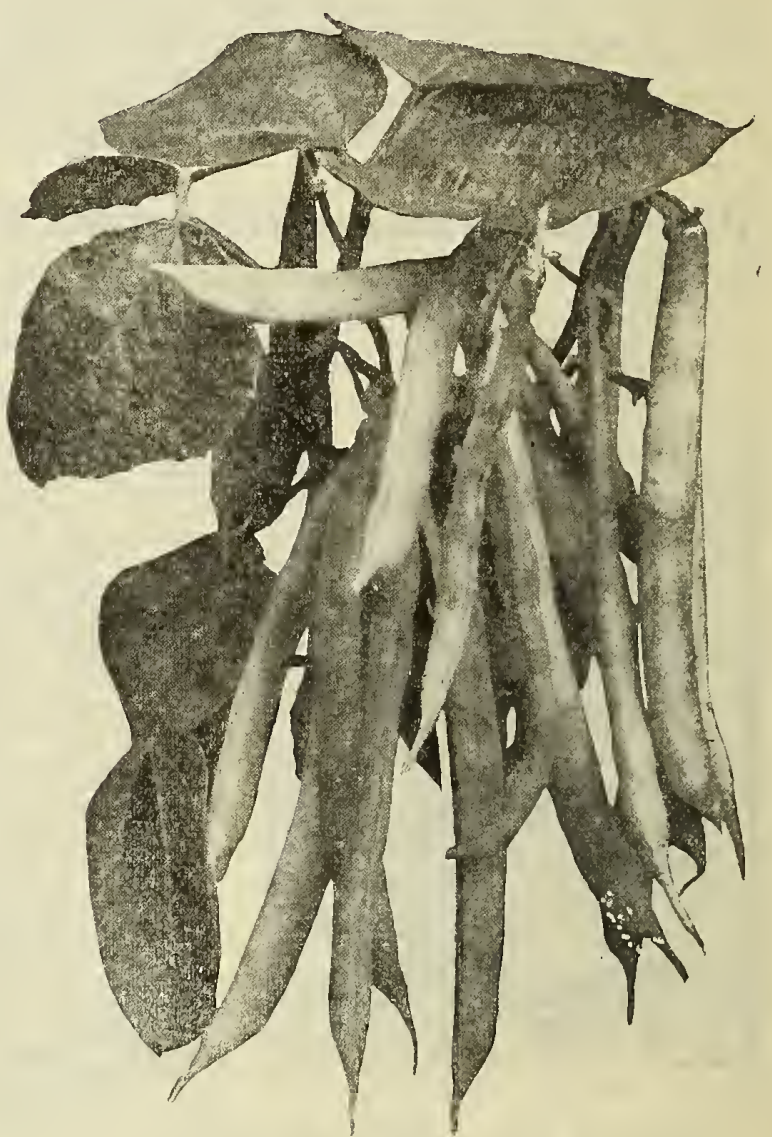

Novelty Dwarf French Bean See Novelties, page 1

\section{POLE or RUNNING BEANS}

IMPROVED KENTUCKY WONDER Old Homestead. A valuable green podded variety, stringless and tender. Most deliciously flavored and very meaty. Lb., 45 cts.; 2 lbs., 80 cts.

SCARLET RUNNER. A favorite sort, both ornamental and useful. Bright scarlet flowers. Lb., 40 cts.; 2 lbs., 70 cts.

LAZY WIFE. An old standby, The best late green podded Pole Bean. Beans round and white, fine for soups. Lb., 50 cts.; 2 lbs., 90 cts.

HORTICULTURAL CRANBERRY. Fine for snap or shell bean. Especially adapted for short seasons, and cool location. Lb., 45 ets. 1 bs., 80 cts.

ENGLISE BROAD WINDSOR BEANS. A great favorite in Europe. A distinct, delicious and very nutritious bean, shelled and cooked the same as Limas. Very hardy. Sow in April in drills, dropping the Beans 2 to 3 ins, apart. Beans can be gathered in June or July. Lb.. 50 cts.; 2 lbs., 90 cts. 
BEANS-Continued

\section{LIMA BEANS (Dwarf Bush)}

BURPEES BUSH IMPROVED. Plants uniformly dwarf and enormously productive. Pods large, containing 4 to 6 large, thick beans of delicious productive. Pods large, containing
flavor. Lb., 55 cts.; 2 lbs., $\$ 1.00$.

FORDHOOK BUSH LIMA. Large pods with 4 to 5 beans, plump and of the finest flavor. Very prolific. Lb. 55 cts.; 2 lbs., $\$ 1.00$.

WONDER BUSH LIMA. Plants are earlier than Burpees, upright and compact in growth, every pod filled with large, thick, handsome beans. Lb., 50 cts.; 2 lbs., 90 cts.

\section{POLE VARIETIES of LIMAS}

EARLY LEVIATHAN. The very earliest large pole Lima. Long broad pods, containing 5 to 6 beans of unexcelled quality. Lb., 40 ets.; 2 lbs., 70 cts.

KING OF THE GARDEN. Pods long, each containing 4 to 6 beans of excellent quality. Produces to the end of the season. Lb., 40 ets.; 2 lbs., 70 cts.

CHALLENGER. Very vigorous grower. Early. Pods thick and prolific. Lb., 40 ets.; 2 lbs., 70 cts.

For Japan Beans, see page 9

\section{BEETS}

One ounce of seed to 50 feet of drill

CROSBY'S SELECTED EGYPTIAN. A remarkably smooth turnipshaped variety, small top and tap root; flesh fine grained; tender and delicious. Pkt., 5 ets.; oz., 20 cts.; $1 / 41 \mathrm{lb} ., 75 \mathrm{cts}$.

CRIMSON GLOBE. One of the season's finest mid-season beets. Flesh is never stringy but red, sweet and tender unsurpassed for slicing. Pkt., 10 ets.; oz., 20 cts.; $1 / 41$ b., 75 cts.

DETROIT DARK RED. A gem for home gardens and unexcelled as a variety for Winter planting. Uniformly smooth dark red, appetizing and very sweet. Pkt., 5 cts.; oz., 20 cts.; $1 / 416 ., 75$ ets.

EARLY ECLIPSE. Extra early. Flesh dark red, zones lighter, crisp and tender. Pkt., 5 cts.; $02 ., 15$ cts.; $1 / 41$ lb., 60 cts.

EDMAND'S EARLY BLOOD TURNIP. One of the best for main and late crops; tops small; dark red; symmetrical roots. Flavor delicate, rich and sugary. Excellent keeper. Pkt., 5 cts.; oz., 20 cts.; 1/4 lb., 50 cts.

EARLY BASSANO. Tender and juicy. Flesh white and rose. Sown late it keeps well into winter. Pkt., 5 ets.; oz., 20 ets.; $1 / 4$ lb., 60 ets.

\section{SWISS CHARD}

This type of beet is grown exclusively for its foliage. The mid-ribs are silvery white, thick and very succulent. They are cooked and served like Asparagus or dressed and boiled like Spinach. It can be used all Summer when Spinach is not available. Pkt., 5 cts.; oz., 20 cts.; $1 / 41$ lb., 60 cts.

GIANT LUCULLUS. Superior moss curled sort; heavy succulent stems. Plrt., 10 ets.; oz., 20 ets.; $1 / 4 \mathrm{lb}$., 65 ets.

\section{BROCCOLI}

WHITE CAPE. Resembles Cauliflower but is much hardier. Heads white, very compact and delicate. Pkt., 15 ets.; $0 z$., 75 ets.

\section{BRUSSELS SPROUTS}

The culture is same as for cabbage. For late use, sow seed in June. This is a delicious vegetable and should find a place in every garden. Sow in May in shallow drills I in. deep and I 2 ins. apart. Transplant in July. Pkt., 10 cts.; $3 / 4$ oz., 20 cts.; $1 / 21 \mathrm{~b} ., \$ 1.00$.

\section{CABBAGE}

One ounce of seed produces about 3000 planls

EARLY JERSEY WAKEFIELD. Selected seed. The leading early sort. Heads are conical, medium size and very solid. Plst., 10 cts.; oz., 40 cts.; $3 / 4$ 1b., \$1.25.

EARLY SPRING. Extra early, round, flat heads, coming in with the Wakefield. Pkt., 5 cts.; oz., 40 cts.; $1 / 4$ lb., $\$ 1.00$.

DANISH BALLHEAD. The favorite Winter cab bage. Extremely hardy, enduring both frost and drought that would destroy other varieties. The most solid headed Cabbage; of the very best quality. Pkt., 10 cts.; 02., 30 cts.; $1 / 4$ 1b., $\$ 1.00$.

COPENHAGEN MARKET. A new early ball shape Cabbage, unexcelled in quality and flavor; heads are solid of uniform size maturing at the same time. Pkt., 10 cts.; $1 / 2$ oz., 30 cts.; 1 oz., 50 cts.; $1 / 41$ lb., $\$ 1.50$.
CABBAGE-Continued

PREMIUM FLAT DUTCH. One of the finest standard late sorts; large flat heads. Pkt., 5 cts.; oz., 30 ets.; $1 / 4$ lb., $\$ 1.00$.

MAMMOTH RED CABBAGE. The largest, best and sure heading cabbage ever introduced, heads round, very solid, fine for pickling and Winter use. Pkt., 10 cts.; oz., 30 ets.; $1 / 4 \mathbf{l b . ,} \$ 1.00$.

IMPROVED AMERICAN SAVOY. None of the later growing equal this sort in flavor and general desirability for family use. Finely crumpled solid round heads. Pkt., 10 ets.; oz., 30 cts.; 1/4 1b., $\$ 1.00$.

ALL SEASONS. Always a sure header, standing the heat of Summer remarkably well and is suited to every growing season. Quality for eating is splendid. Pkt., 10 cts.; 0z., 25 cts.; 1/4 1b., $\$ 1.00$.

For Japanese and Chinese Cabbage, see page 8 .

\section{CARROTS}

One ounce sows roo feet of drill

Sow from April to June in drills I $\mathrm{ft}$. apart, covering the seed one-half inch. Thin out the plants 3 to 5 ins. apart according to variety. Keep the soil well cultivated as young plants will be ruined by neglect and weeds. Drought is to be especially avoided.

EXTRA EARLY PARISIAN FORCING. The earliest Carrot in cultivation, the easiest grown for forcing and splendid for open ground. Roots are globe shaped and of mild sweet flavor. Pkt., 10 cts.; oz., 30 cts.; $1 / 4$ lb., $\$ 1.00$.

DANVERS IMPROVED HALF LONG. Most popular sort for family use. Handsome slender carrots of good size; dark orange color withuse. Handsome slender carrots of good size; dark orange color with-
out core and of finest flavor. Seed very scarce. Pkt., 10 cts.; oz. 30 ets.; $1 / 41 \mathrm{lb}$., $\$ 1.00$.

EARL Y CHANTENAY. One of the very best table varieties, very smooth, sugary and sweet. Pkt., 5 cts.; oz., 25 cts.; $1 / 41$ b., 60 cts. GUERANDE or OXHEART. Of rapid growth, an excellent cropper. tri Pkt., 5 cts.; oz., 25 cts.; $1 / 4$ lb., 75 cts.

EARLY SCARLET HORN. Stump rooted, fine grained, delicate flavor. Pkt., 5 ets.; 0z., 25 cts.; $1 / 1 / 4$ lb., 75 cts.

IMPROVED LONG ORANGE. Well known sort, good keeper; valuable both for garden and field. Pkt., 5 cts.; oz., 20 ets.; 1 lb., 60 ets.

\section{CAULIFLOWER}

Cauliflower succeeds well in any soil where Cabbage will grow. It delights in a rich soil and plenty of water. Pursue the same general directions as for growing Cabbage, watering liberally during dry weather. An occasional application of liquid manure is beneficial.

EXTRA EARLY SNOWBALL. Heads are white, solid, and finely grained; none better. Pkt., 25 cts.; $1 / 4$ oz., $\$ 1.00 ;$ oz., $\$ 2.50$.

EARLY DWARF ERFURT. A very early carefully selected strain producing large white heads. Pkt., 50 cts., $3 / 4$ oz., $\$ 1.50$.

AUTUMN GIANT. A remarkably strong growing late sort; plant in May and June. Pkt., 10 cts.; $1 / 4$ oz., 25 cts.; oz., 75 ets.

DANISH DRY WEATHER. This variety of Cauliflower is especially adapted for sections subjected to long, dry seasons, as it will grow well and produce the finest heads in spite of the lack of moisture which is required by other sorts. The heads grow to a large size, are very solid, pure white and of delicious flavor. Pkt., 25 ets.; $1 / 4$ oz., $\$ 1.00 ; 1 / 2$ oz., $\$ 1.75$.

\section{CELERY}

PERFECTION WHITE PLUME. Best for early use. The stalks and portions of the leaves being naturally white, they are fit for table use early in season. Pkt., 10 cts.; oz., 40 cts.; $1 / 4 \mathrm{lb}$., $\$ 1.25$.

GOLDEN SELF-BLANCHING. Stringless, crisp, sweet and tender; a popular favorite extensively grown for Summer and early Autumn use. It keeps well. Pkt., 15 cts.; oz., \$1.25.

BOSTON MARKET. Of dwarf branching habit, solid and crisp with delicious nutty flavor. Always gives satisfaction. Pkt., 15 cts.; oz., 75 cts.

GIANT PASCAL. An easily blanched and wonderful keeping sort. The stalks will snap like glass they are so tender. Grows about two feet high. Pkt., 10 cts.; 0z., 25 cts., 1/4 lb., \$1.00.

PINK PLUME. Similar to White Plume; stalks rose tinted.

Pkt., 15 cts.

\section{CELERIAC or STUMP-ROOTED CELERY}

Grown for its roots for delicious salads, soups, stews. Sow the seed same as Celery, transplant into rows $2 \mathrm{ft}$. apart, 6 to 8 ins. in the row. No earthing is required for this Celery as it is the roots which are the edible portion.

LARGE SMOOTH PRAGUE. Very large and fine. Plst., 5 cts.; oz., 25 cts.; $1 / 4$ lb., 90 cts.

CELERY SEED FOR FLAVORING. Oz., 10 ets.

\section{CHERVIL}

The young leaves are used for seasoning soups and salads. P年t., 10 cts.; oz., 20 ets. 


\section{CHIVES}

Used for salads and soups. One sowing will last nearly three years. Pkt., 10 ets.

\section{CORN SALAD or LAMB'S LETTUCE}

A small.quick growing salad plant. Used as a substitute for Lettuce and Spinach. Pkt., 5 cts.; 0z., 10 ets.; $1 / 4$ lb., 35 ets.

\section{CRESS}

EXTRA CURLEd. Fine for garnishing. Pkt., 5 cts.; oz., 10 ets.

UPLAND CRESS. Hardy. Ready for use a week earlier. The spicy tender leaves form a delicious Spring salad. and are excellent for savory sandwiches. Pkt., 10 ets.; oz., 30 cts.

TRUE WATERCRESS. This delightful, wholesome salad and garnishing plant may be grown to perfection in any moist and rich soil whether naturally or artificially kept wet. Plkt., 10 cts.; oz., 35 ets.

\section{SWEET CORN}

\author{
One pound to roo hills
}

\section{EXTRA EARLY SORTS}

GOLDEN BANTAM. A very rapid grower producing ears measuring 5 to 7 ins. No finer or sweeter Corn is grown. It is very early but can be planted throughout the season. The ears are borne two to a stalk and, on account of its medium height, it can be planted closer together than high Corn which makes it well adapted for the home garden. Unrivalled in quality. Pkt., 10 cts.; lb., 50 cts.; 2 lbs., 90 cts.

PEEP-O-DAY. One of the earliest real sweet Corns; eight-rowed. Pkt. 10 ets.; lb., 35 ets.; 2 lbs., 60 ets.

EXTRA EARLY WHITE CORY. Long ears with deep narrow kernels of a rich cream color. Excellent for family use. Pkt., 10 ets.; 1b., 30 cts.; 2 lbs., 55 cts.; 10 lbs., $\$ 2.75$.

CROSBY'S EARLY SUGAR. The ears are fine size, set very low with 12 to 16 rows of pearly white kernels of delicious sweetness. Pkt. 10 ets.; 1 b., 40 ets.; 2 lbs., 70 ets.

\section{MEDIUM EARLY}

SQUANTUM or POTTER'S EXCELSIOR. As a medium early sort this is unsurpassed. Ears of good size well filled with rows of white and juicy kernels. Pkt., 10 ets.; lb. $40 \mathrm{c} ., 2 \mathrm{lbs}$., 70 cts.

STOWELL'S EVERGREEN. The standard home variety. The best all around sweet Corn grown. Magnificent large ears, deep kernels, small cob; of finest flavor, tender and juicy. Pkt., 10 cts.; 1b. 10 cts.; 2 lbs., 70 ets.; 10 lbs., $\$ 3.00$.

\section{LATE}

COUNTRY GENTLEMAN. Very productive with long ears with deep set white kernels. Deliciously sweet, tender and milky. Pkt., 10 ets., lb., 45 cts.; 2 lbs., 80 cts.; 10 lbs., $\$ 3.50$.

BLACK MEXICAN. Very sweet and tender. Bluish black when ripe, cooking almost white. Pkt., 10 cts.; lb., 40 ets.; 2 lbs., 70 ets.

\section{CUCUMBERS}

\section{One ounce will plant 50 hills}

Culture. Cucumbers succeed best in warm, moist, rich loamy soil. Sow in the open ground as soon as the weather has become settled and warm, in hills 4 to $6 \mathrm{ft}$. apart each way. Thin out to four plants to each hill after all danger of insects is over. Continue planting at intervals for succession.

IMPROVED EARLY WHITE SPINE. Fruits even, smooth and slender, attractive glossy dark green; excels in crispness and flavor. Pkt., 5 ets.; oz., 20 ets.; $1 / 4$ lb., 50 ets.

DAVIS PERFECT. One of the most prolific for outside growing. The fruit is straight and free from bulge and of ten measures I2 ins. Almost seedless and resembles a hothouse cucumber. Pkt., 5 ets.; oz., 15 ets.; $1 / 1,1 \mathrm{lb} .40 \mathrm{cts}$.

PERFECTION RIDGE ENGLISH GROWN. Fruits a fine green, of handsome shape, varying in length from I2 to 15 ins. They bear with great freedom and abundance. The plants are hardy and robust. Can be grown on ridges, on wires or poles. "This sort will please the most exacting on rer. Pkt., 20 ets.; trial pkt., 10 ets.

COOL AND CRISP. Very early; long and slender. Fine for slicing. Pkt., 5 cts.; oz., 15 ets.; $1 / 4$ lb., 40 ets.

THE CUMBERLAND. Its extreme earliness combined with its prolific and hardy qualities make it a very desirable variety for either market or home use. Flesh firm, crisp and tender. Excellent for both pickles and slicing. Pkt., 5 cts.; oz., 20 ets.; $1 / 4$ lb., 50 cts.

FORDHOOK FAMOUS. Quality superb. Color dark green. A white spine variety 7 ins. long. Pkt., 5 cts.; oz., 25 ets.; $1 / 4$ lb., 50 ets.

WEST INDIA GEERKIN. A small oval prickly variety used for pickling only. Pkt., 10 cts.; oz., 20 ets.; $1 / 4$ lb., 90 cts.

GREEN PROLIFIC PICKLING. Fine shape, right size and excellent quality makes this an ideal pickling Cucumber. Pkt., 5 cts.; oz., 15 cts.; $1 / 4$ lb., 50 cts.

\section{DANDELION}

IMPROVED LARGE LEAVED. Very vigorous, producing large leaves which blanch well. Makes a most delicately flavored and wholesome salad. Pkt., 10 cts.; oz., 60 cts.

\section{EGG PLANT}

One ounce will produce about 1000 plants.

BLACK BEAUTY. Of a beautiful rich purple color; fruit is large, thick and attractive. Pkt., 10 cts.; 1/2 oz., 25 ets.; oz., 45 ets.

BLACK PEKIN. Produces handsome jetblack fruit of superior quality. Pkt., 5 ets.; oz., 25 cts.; $1 / 4$ lb., 75 cts.

NEW YORK IMPROVED. Easily cultivated. Fruit smooth and round. It has a meaty flavor, much liked by everybody. Pkt., 10 cts.; oz., 35 ets.

\section{ENDIVE}

One ounce will sow 200 feet of drill

GREEN CURLED. Has deep green leaves finely crinkled and curled. Pkt., 5 ets.; oz., 20 ets.

WHITE IVORY CURLED. Blanching ravidly; excellent and very tender. Pkt., 10 ets.; oz., 25 ets.; 1/4 lb., 75 ets.

FRENCF MOSS CURLED. Very finely curled with close dense leaves. Pkt., 10 cts.; oz., 25 cts.

BROAD-LEAVED BATAVIAN. Broad thick leaves with rounded ends. The Parisian "Escarolle." Used as a salad and also like Spinach Pkt., 5 cts.; oz., 20c.; $1 / 4$ lb., 60 ets.

\section{KALE or BORECOLE}

DWARF GREEN. One of the best. Pkt., 5 cts.; oz., 10 ets.

SIBERIAN KALE or SPROUTS. Should be sown in September and treated like soinach; it is fit to cut early in Spring. Pkt., 5 ets.; oz., 10 ets.; $1 / 4$ lb., 25 ets.

\section{KOHLRABI}

EARLIEST PURPLE, Verý easily grown; has a delicious Cauliflower flavor, appetizing and pleasant. Cooked like Cauliflowier or Turnips, with cream sauce. Pkt., 10 ets.; $02 ., 30$ ets.; $1 / 1 / 1$ lb., 85 ets.

\section{LEEK}

LARGE AMERICAN FLAG. Most desirable; mild agreeable flavor. Pkt., 5 ets.; 0z., 20 ets.; $1 / 1 / 4$ lb., 60 ets.

\section{LETTUCE}

Easily grown either in hotbed or garden and can be sown very early.

MAY KING. Plant in the early Spring in the open ground. Produces splendid globular heads; leaves light green, interior creamy yellow; very: tender and unexcelled in flavor. Pkt., 5 cts.; oz., 25 cts.; $1 / 41$ lb., 75 cts.

BIG BOSTON. None better for the kitchen garden for Fall or early Spring use; large heads; bright, tender green leaves. Pkt., 5 ets.; oz., 20 ets.; $1 / 4$ lb., 75 cts.

WONDERFUL. A large solid hearted variety; pale green, very tender and crisp. Pkt., 5 ets.; oz., 20 ets.; $1 / 4$ lb., 75 cts.

HANSON. Exceedingly popular for Midsummer planting; a sure header. resisting drought and heat. Pkt., 5 cts.; $0 z$, 20 cts.; $1 / 41$ b., 75 cts. id CRISP-AS-ICE. Fine large heads; When cut open they have a rich, creamy heart and are tender enough to "melt in the mouth." Pkt.. 5 cts.; oz., 20 ets.; $1 / 4$ lb., 75 ets.

CREAM BUTTER. A crisp, tender, richly flavored variety, forming large heads of a beautiful creamy color. One of the best Summer varieties grown. Pkt., 10 ets.; oz., 30 ets.; $1 / 4$ lb., $\$ 1.00$.

SALAMANDER PERFECTED. Has excellent heat-resisting qualities; grows to large size. with tightly folded leaves covering the centre, which blanches a light golden. Pkt., 5 ets.; oz., 20 ets.; $1 / 1 / 1$ lb., 60 ets.

TENNIS BALL BLACK SEEDED. A standard sort. Pkt., 5 ets.; oz., 20 ets.

ALL SEAsons. Color light green, inside leaves clear yellow. Produces remarkably large firm heads. Absolutely withstands heat and drought: Pkt., 5 cts.; oz., 20 ets.; $1 / 1 / 1$ lb., 40 cts.

BLACK SEEDED SIMPSON Loose Head. A popular curly leaved sort, always reliable, easily grown. Good for amateurs to try. Pkit., 5 ets.; oz., 20 ets.; $1 / 41$ lb., 40 ets.

GRAND RAPIDS FORCING. A popular curly leaved sort. Very early. Crisp leaves of light green, melting in the mouth. Pkt., 5 cts.; oz., 20 ets.; $1 / 4$ lb., 40 ets. 
COS or ROMAINE LETTUCE

PARIS White COS. One of the best for Summer use. Self closing. Pkt., 5 cts.; oz., 15 cts.; $1 / 4$ lb., 40 cts.

TRIANON COS. Long narrow leaves. Tender, crisp and buttery. Pkt., 5 cts.; oz., 20 cts.; $1 / 4$ lb., 50 cts.

\section{MUSTARD}

Green Mustard imparts a delightfully pungent flavor to various forms of prepared salads. Sow at frequent intervals through the Spring in drills 8 to 12 ins. apart.

WHITE LONDON. Pkt., 5 cts.; oz., 10 cts.; $1 / 41$ lb., 25 cts.

JAPANESE MUSTARD, see page 9.

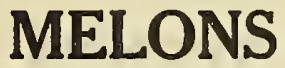

One ounce will plant 50 hills

\section{MUSKMELONS}

Cultivate in hills which should be 5 to $6 \mathrm{ft}$. apart each way, and composed of light, moderately rich soil. Plant in May, ten seeds to the hill; when the plants are well up thin out to three. Pinch the ends of the growing shoots to induce early fruiting.

EMERALD GEM. A deep green on the outside with a beautiful salmon color inside makes this little gem as beautiful to look at as it is deliciou in flavor; medium sized and exceedingly early. The rind is thin and deeply netted. The flesh is thick and so rich and juicy that it needs to be eaten with a spoon. A "Gem" in every way. Plit., 10 cts.; oz., 25 ets.; $1 / 41 \mathrm{lb}$., 45 ets.

EXTRA EARLY HACKENSACK. One of the best, earliest. hardiest, most prolific of netted melons. Flavor fine. Plt., 5 ets.; $02 ., 15$ cts.; $1 / 4$ lb., 35 cts.

JENNY LIND. One of the most popular sorts. Fruit round, flattened with rind thick at ends. Good size, deep meated, tender, melting, and of the richest flavor. Pkt., 10 cts.; oz., 30 cts.; $1 / 41$ lb., 75 ets.

ROCKY FORD NETTED. A famous variety which can be relied upon for producing the finest Melons it is possible to grow. The flesh is thick, green tinted and very aromatic and sweet. In flavor it is delightfully rich and spicy. Pkt., 10 cts.; oz., 25 cts.; $1 / 4$ lb., 75 cts.

LON G ISLAND BEAUTY. Round fruit; flesh deep orange. One of the earliest and best. Pkt,, 10 cts.; oz., 25 cts.; $1 / 4$ lb., 75 cts.

BURRELL'S GEM. Grows uniform in size and weight. Small, sweet and spicy. Pkt., 5 cts.; oz., 20 cts.; $1 / 4$ lb., 50 cts.

\section{WATERMELON}

One ounce will plant 50 hills

Culture same as Muskmelon except that they should be planted 6 to 8 feet apart each way.

COLES' EARLY. A most delicious and productive variety for the family garden succeding in Northern states where Melons were never matured before. The flesh is of a beautiful bright red color, criso and extremely delica te in texture; in flavor it is lusciously sweet and refreshin no pithiness or stringiness. Pkt., 10 cts.; oz., 25 cts.; $1 / 41 \mathrm{lb} ., 65$ ets.

KLECKLEY'S SWEETS. Sweetest of All. Fine flavored and grained; tender meat. Fruits are large size, rind very thin and green; very brittle; flesh scarlet and firm. A variety every one should grow. Pkt., 10 ets.; oz., 25 cts.; $1 / 4$ lb., 65 cts.

TOM WATSON. Produces fruits 18 to 24 ins. long by Io to $I 2$ ins. in dia meter. Rind thin but strong. Flesh excellent, can be eaten almost to the skin. Pkt., 10 cts.; oz., 20 ets.; $1 / 41$ lb., 60 cts.

KOLB'S GEM. Oval light green, mottled. A fine shipper. Pkt., 5 cts.; oz., 10 ets.; $1 / 4$ lb., 25 cts.

CITRON FOR PRESERVES. Round and handsome; most valuable in jelly making. Jellies will "Jell Perfectly" if the pulp of this is added to them. Be sure and plant a few. Pkt., 5 cts.; oz., 15 ets.; $1 / 4 \mathbf{l b .}$, to them.

\section{OKRA or GUMBO}

Should be planted in every garden. Is extremely easy to grow. The green pods are used in soups, stews, etc., to which they impart a rich flavor. Sow the seed thickly in rich ground about the middle of May when warm, in drills $3 \mathrm{ft}$. apart, $\mathrm{I}$ in. deep; thin to Io ins. apart.

WHITE VELVET. Large thick pods, round and smooth. Plt., 5 ets.; oz., 10 cts.

LONG GREEN, Long ribbed pods. Very productive. Pkt., 5 ets.; oz., 10 cts.; $1 / 1$ lb., 20 ets.
ONIONS

One ounce to Ioo feet of drill.

Sow in rich, rather sandy, but well manured soil, as early as possible in Spring, in shallow drills, I ft. apart, covering with fine soil $3 / 4$-inch, which should be pressed down with the back of a spade. When the young plants are strong enough, thin out to 4 ins. Keep free from weeds.

AILSA CRAIG English stock. Handsome globular variety, flesh white; skin pale yellow. An ideal variety. Pkt., $25 \mathrm{cts}$.; $0 z ., 60 \mathrm{cts}$; $1 / 4 \mathrm{lb}$., $\$ 2.00$.

Improved Yellow Globe Danvers. Plump, handsome, yellow skinned bulbs, uniform round and perfect, white flesh, fine thin neck. Does well in all soils and climates. Plt., 5 cts.; oz., 25 cts.; $1 / 41$ lb., $\$ 1.00$.

SOUTHPORT WHITE GLOBE. Very firm; fine grained white flesh crystal clear and mild flavored. Pkt., 10 cts.; oz. 60c.; 1/4 1b., $\$ 2.00$. SOUTHPORT YELLOW GLOBE. Like all the Globes, wonderful keepers; deliciously tender and sweet. Pkt., 5 cts.; oz., 50 cts.; $1 / 4$ lb., $\$ 1.50$.

SOUTHPORT RED GLOBE. A heavy yielder, rich dark red, sound and solid. Pkt., 5 ets.; oz., 45 ets., $1 / 4$ lb., $\$ 1.00$.

RED WETHERSFIELD. Round, somewhat flattened bulb. Fine grain and mild flavor. A favorite red skinned sort. Does best in poor soil. Pkt., 5 cts.; oz., 40 cts.; $1 / 4$ lb., $\$ 1.00$.

MAMMOTH SILVER KING. Matures early. Flat shaped but thich, mild and tender, silvery white flesh. Ideal for market or table. Pkt. 10 cts.; oz., 60 cts.; $1 / 4$ lb., $\$ 2.00$.

ADRIATIC BARLETTA. Very early. Can be eaten raw. Small flat and waxy white. Invaluable for pickling. Pkt., $10 \mathrm{cts.;} 1 / 2$ oz., 25 cts.

\section{ONION SETS}

\section{Prices variable}

WHITE SETS. Qt., 30 cts.; $1 / 2$ pk., $\$ 1.00$.

YELLOW SETS. Qt., 30 cts.; 1/2 plk., 90 cts.; pk., $\$ 1.60$.

RED SETS. Qt., 30 cts.; $1 / 2$ pk., $\$ 1.00 ;$ pk., $\$ 1.75$.

We do not prepay on Onion Sets. Mailing weight one 1b. per qt. JAPANESE ONIONS, see page 8.

\section{PARSLEY}

One ounce will sow too feet of drill

Parsley requires a rich, deep and rather mellow soil. Sow early in Spring, I ft. apart and $1 / 2$ in. deep, previously soaking the seed a few hours. Thin out to 4 ins.

PLAIN. Very hardy and flavor excellent. Pkt., 5 cts.; oz., 15 cts.; $1 / 1$ lb., 35 ets.

CHAMPION MOSS CURRED. Of a shining rich color, robust, compact. Plants can be grown in pots or window boxes. Pkt., 5 cts.; oz., 15 cts.; $1 / 1$ lb., 35 cts.

HAMBURG or ROOTED. Grown for its roots. Used for flavoring soups. Plt., 5 cts.; oz., 20 cts.; 1/4 lb., 50 cts.

\section{PARSNIPS}

Sow in rich soil, in drills about I8 ins. apart, as early in the Spring as the ground can be worked.

AMERICAN HOLLOW CROWN. One of the best. Smooth, large tender and sugary. Plit., 5 ets.; oz., 10 ets.; $1 / 1 / 1$ lb., 30 ets.

EARLY ROUND. Adapted to shallow soil. Early and fine for a change when a new vegetable is most relished. Try them, stewed, fried, etc. Pkt., 5 cts.; oz., 10 cts. ; $-1 / 4$ lb., 30 cts.

\section{PEPPERS}

No trouble whatever to grow.

Sow in April, in a hotbed, in shallow drills, covering $1 / 2$ in. and 6 ins. apart and transplant to the open as soon as weather is warm. Soil should be rich and sandy.

LARGE BELL or BULL NOSE PEPPER. Standard early scarlet variety. Produce abundantly and bear well till frosts. Pkt., 5 cts.; $02 ., 50$ ets.; $1 / 41$ b., $\$ 2.00$.

RUB Y KING. The large Peppers are bright ruby red, remarkably milc and pleasant to the taste. Can be sliced and eaten with Tomatoes and Cucumbers. Plt., 5 cts.; $1 / 2$ oz., 35 cts.; $1 / 4$ lb., $\$ 1.25$.

CHINESE GIANT. Enormous deep crimson Peppers, very productive. The fruits grow 4 to 5 ins. broad and are of equal length. Thick mild flesh, Pkt., 5 cts.; $1 / 20 z_{\text {., }} 40$ cts.; $1 / 4$ lb., $\$ 2.50$.

GOLDEN DAWN. Golden yellow, sweet and mild flavor. Pkt., 10 ets.; $1 / 2$ oz., 25 cts.; $1 / 4 \mathrm{lb}$., $\$ 2.00$.

CHERRY RED. Small round fruit, glossy scarlet, extremely diquant.

Pkt., 5 ets.; oz., 50 ets.; 1/ 1 lb., $\$ 2.00$.

NEAPOLITAN. Extra early. Flesh thick and sweet. Most palatable.

Plkt., 5 cts.; oz., 65 cts.; $1 / \frac{1}{4}$ lb., $\$ 2.00$.

JAPANESE PEPPER, see page 9 . 


\section{GARDEN PEAS}

One pound will plant about 50 feet of drill

Packets of any sort listed are Io cts. If by parcel post add postage at Zone rates. One pound is equal to about a pint. To points East of Mississippi River, 7 cts. Der pound. To points West of Mississippi River, I2 cts. per pound.

\section{VERY EARLY VARIETIES}

LITTLE MARVEL. Most satisfactory for the small garden. Vines strong and hardy, each bearing 4 to 7 large green pods; quality luscious and sugary. Lb., 35 ets.; 2 lbs., 60 cts.

ALASKA or EARLIEST OF ALL. A standard variety for market and canning. Well filled pods, seeds bluish in color; excellent and always reliable. Lb., 35 ets.; 2 lbs., 60 cts.; 10 lbs., $\$ 2.50$

AMERICAN WONDER. An early wrinkled Pea of exquisite flavor, ready for the table in 30 to 40 days after planting. Grows only 10 to $I 2$ ins. high. Plant every week for succession. Lb., 35 ets.; 2 lbs., 60 ets.; 10 lbs., $\$ 2.50$.

NOTT'S EXCELSIOR. A popular favorite; hardy and vigorous. May be planted as early as the round sorts and will mature almost as soon. Bears heavy clusters of blunt pods about 3 ins. long. Tender and delicious to eat. Lb., 35 cts.; 2 lbs., 60 ets.; 10 lbs., $\$ 2.50$.

\section{MEDIUM VARIETIES}

GRADUS or PROSPERITY. Early large podded Marrow Pea. The largest early Pea grown. Pods are uniform, filled to bursting with rich, plump, fine peas. Height $21 / 2$ to 3 feet. Lb., 40 cts.; 2 lbs., 70 ets.; 10 lbs,. \$3.00.

\section{LATE AND MAIN VARIETIES}

MeLEAN'S ADVANCER. Very productive, of excellent quality. Lb. 35 ets.; 2 lbs., 60 ets.; 10 lbs., $\$ 2.50$.

DWARF TELEPHONE. Unequalled as a main crop variety; long broad pods, dark green and handsome. Excellent quality. Lb., 40 ets.; 2 1 bs., 70 ets.

CHAMPION OF ENGLAND. Holds its own among all new comers. The vines mature to about $5 \mathrm{ft}$. high and are very vigorous. Pods filled The vines mature to about $5 \mathrm{ft}$. high and are very vigorous. Pods filled
with Peas of superb flavor. Lb., $\mathbf{3 5}$ ets.; 2 lbs., 80 cts.; 10 lbs., $\$ 2.50$. ALDERMAN. One of the best of the large podded varieties; immensely prolific. Peas of the best quality. Lb., 35 cts.; 2 lbs., 60 ets.

YORKSHIRE HERO. Old standard variety. Bears abundantly and is fine for late crop. Peas wrinkled, sweet and large. Lb., 35 cts.; 2 lbs., 60 ets., 10 lbs., $\$ 2.50$

QUITE CONTENT. One of the largest podded varieties in cultivation. Pods straight and closely filled with Peas of rich fiavor. Lb., $\mathbf{3 5}$ cts.; 2 lbs., 60 ets.; 10 lbs., $\$ 2.50$.

MELTING SUGAR PEAS. Edible podded. The pods are cooked like snap beans, are very sweet and tender. A delightful dish. Lb., $\mathbf{4 0}$ cts.; 2 lbs., 70 ets.; 10 lbs., $\$ 3.00$.

IMPROVED TELEPHONE. A tall and robust grower. Superb flavor and tender. Height $5 \mathrm{ft}$. Unequaled as a main crop variety. Lb., 40 ets.; 2 lbs., 70 ets.; 10 lbs., $\$ 3.00$.

\section{PUMPKINS}

LARGE CHEESE. Very popular. Keeps splendidly when stored in a dry place. Fine, sweet flavor. Pkt., 5 cts.; oz., $10 \mathrm{cts}$; $1 / 4$ lb., 40 cts. SUGAR PIE or SWEET PUMPKIN. Fruit medium, sugary and delicious

"For the pies that Mother used to make." Pkt., 5 cts.; oz., 10 cts.;

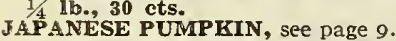

\section{RADISHES}

One ounce will sow roo feet of drill

Culture.--Radishes require a light loamy soil, moderately fertile, which should be deeply dug and well pulverized. The situation should be warm and sheltered. For an early supply, sow 1/2 inch deep in January or February in hotbeds, keeping well ventilated. In April they may be sown out-of-doors in drills 12 to 18 ins. apart. Thin to 2 ins. apart to prevent crowding. Successive sowings should be made every two weeks. Radishes to be crisp and tender should make a rapid growth. They can be stored for Winter like Turnips.

COOPER'S SPARKLER. A quite distinct new sort of a beautiful rich carmine scarlet, with a pronounced tip of pure white. Plrt., 5 cts.; oz., 25 ets.; $1 / 4$ lb., 75 ets.

RIMSON GIANT. This variety is suitable for either forcing or early planting outdoors. Does not get pithy or hollow. Sow the seed thinly. Plkt., 5 ets.; oz., 20 ets.; $1 / 4$ lb., 60 ets.

EARL Y SCARLET GLOBE. A variety of distinct shape, very attractive. For early planting; is ready for the table in 25 days. Pkt., 5 ets.; oz., 15 cts.; $1 / 1$ lb., 50 ets.

EARLY SCARLET TURNIP. Prized for its quick growth as well as for its tenderness and crispness. In every way it is satisfactory; a veritable dainty. Ready for use in 20 days after sowing. Flavor mild and delightful at all times. Pkt., 5 ets.; oz., 20 ets.; 1/4 lb., 50 ets.

ERENCH BREAKFAST RADISH. Can be used for Summer sowing or for forcing. Growing rapidly in the early Spring this Radish has a skin that is very tender; the flesh is pure white, sound, solid and sweet, appealing to the eye and palate. An ideal early sort. Pkt., 5 cts.; oz., 20 ets.; $1 / 4$ lb., 50 ets

CICLE. Long slender roots of transparent whiteness. One of the earliest of the long sorts. Crisp and tender, both when young and later. Pkt., 5 cts.; oz., 15 cts.; $1 / 4$ lb., 50 cts.

LONG WHITE VIENNA. Beautiful shape; pure white, crisp, brittle and of very rapid growth. Pkt., 5 ets.; oz., 15 cts.; $1 / 4$ lb.. 50 ets.

SCARLET OLIVE SHAPED. Rapid grower. Oval, tender and excellent

Pkt., 5 cts.; oz., 20 cts.; $1 / 4$ lb., 50 cts.
RADISH-WINTER VARIETIES

LONG BLACK SPANISH. Popular Winter sort. Pkt., 5 ets.; oz.,'15

ROUND BLACK SPANISH. Pkt., 5 ets.; oz., 10 ets.; $1 / 4$ lb., 40 ets.

ROSE CHINA WINTER. Bright rose color; flesh firm. Pkt., 5 ets.; oz., 10 ets.; $1 / 1$ lb., 45 ets.

JAPANESE RADISHES, see page 8.

\section{RHUBARB}

Culture.-A deep rich soil trenched to a depth of $2 \mathrm{ft}$. is best for Rhubarb It is usually grown from roots.

VICTORIA. The best variety. Stalks red, thick and long. Pkt., 5 ets.;

oz., 20 ets.; $1 / 4 \mathrm{lb}$., 60 ets.
vICTORIA. Strong clumps. 15 ets each; $\$ 1.50$ per doz.

STRAWBERRY. Unsurpassed for making sauce and pies. Strong clumps. 25 ets each; $\$ 2.50$ per doz.

\section{TURNIPS}

One ounce will sow $\mathrm{I} 50 f_{\text {eet }}$

Sow as soon as the ground opens in Spring. For a late crop sow in July Sow in drills 18 ins. apart and thin to 6 ins. in the drill. Can be sown

EXTRA EARL $Y$ WHITE MILAN. A splendid turnip, clear solid white, tender and sweet. Plkt., 5 ets.; oz., 40 ets.

EARLY SNOWBALL. Ready in 6 week. $^{\circ}$ time. Tender and delicate round as a ball, pure white flesh and skin. Pkt., 5 cts.; oz. 10 ets.; $1 / 1 \mathbf{l b} .30 \mathrm{cts}$.

PURPLE TOP MILAN, Splendid quality. Medium size, flat, white with a bright purple top. Pkt., 5 cts.; oz., 15 ets.; $1 / 41$ lb., 35 ets.

AMBER GLOBE or ORANGE JELLY. A superior table turnip. Beautiful color and fine grained. Pkt., 5 ets.; oz., 15 cts.; $1 / 4$ lb., 30 ets.

WHITE EGG. Oval, mild and very sweet. Pkt., 10 ets.; oz., 20 ets.;

$1 / 4$ lb., 50 cts.

\section{RUTABAGA or SWEDISH TURNIP}

AMERICAN PURPLE TOP. Purple top yellow Turnip; fine quality Keeps well. Pkt., 5 ets.; oz., 15 ets.; $1 / 4$ lb., 35 ets.; lb., $\$ 1.00$ SHAMROCK SWEDE. An excellent yellow fleshed purple top variety Small, short neck. Heavy cropper and one of the best. Plt., 5 cts.; oz., 10 ets.; $1 / 1$ lb., 25 ets.

WHITE FRENCH or ROCK. Firm hard flesh; excellent quality. Pkt., 5 cts.; oz., 10 cts.; $1 / 4$ lb., 25 cts.
JAPANESE TURNIPS,

\section{SALSIFY (Oyster Plant)}

\section{One ounce will sow 50 feet of drill}

A most delicious vegetable. It is used stewed, boiled or fried. Culti-

vation the same as for Carrots or Parsnips.
MAMIMTH SANDWICH ISLAND. Tender and delicious. Pkt., 10 cts.; oz., 25 ots.; $1 / 4$ lb., 75 cts.

BLACK SÁLSIFY, or SCORZONERA. A black variety. Flesh tender and white, Plit., 10 cts.; 0z., 25 cts.; $1 / 4$ lb., 50 ets.

\section{SEA KALE}

Cultivated for its blanched shoots, which are cooked the same as Asparagus. They have a very agreeable nutty flavor, slightly bitter. Pkt., 10 ots.; oz., 30 cts.; $1 / 4$ lb., $\$ 1.00$.

\section{SORREL}

Agreeable as a salad or dressing. Sow in shallow drills 12 ins. apart, and thin out the young plants to 6 ins. Plkt., 5 cts.; 0z., 25 cts.; $1 / 4$ lb., 60 cts.

\section{SPINACH}

One ounce will sow roo feet

Requires very rich soil to be succulent and tender. For Summer use sow early in Spring in drills I5 ins. apart and make successive sowings every two weeks. For Spring use sow in September and cover lightly in November with litter.

ROUND THICK LEAVED. A standard sort equally good for Spring or Fall. Plkt., 10 ets.; oz., 25 cts.; $1 / 1 / 4$ lb., 75 ets.

LONG STANDING. Excellent for Summer. Delicious tender quality. Pkt., 10 ets.; oz., 25 cts.; $1 / 1$ lb., 75 cts.

SAVOY LEAVED or BLOOMSDALE. Large, tender crumpled leaves; very hardy. Pkt., 10 ets.; oz., 25 cts.; $1 / 4$ lb., 60 ets.

VIROFLAY or GIANT LEAVED. An improved strain. With broad

thick leaves, very tender and weli flavored Ouick, strong growth and thick leaves, very tender and well fiavored. Quick, strong growt
stands the heat well. Pkt., 10 ets.; oz., 25 ets.; $1 / 4$ lb., 75 ets.

stands the heat well. Pkt., 10 ets.; oz., 25 ets.; $1 / 4 \mathbf{1 b}$., 75 ets.
VICTORIA. lent leaves. Pkt., 10 ets.; oz., 25 ets.; $1 / 4$ lb., 65 ets.

NEW ZEAL AND. 'Especially suited for hot Summer months, makes a low spreading plant from which tender greens can be gathered the entire Summer. Soak the seed 24 hours in tepid water before planting. Pkt. 10 cts.; oz., 25 cts.; $1 / 4$ lb., 65 cts.

NOTE.-Spinach seed is very scarce this season. 


\section{SWISS CHARD (Spinach Beet)}

EProduces more food for the table than almost any other vegetable. Requires the least of care or space and it can be used all Summer when Spinach is not available. Sow as early in Spring as the ground can be pinach is not avaliable. Sow as early in spring as the ground can be worked, in rows I2 ins. apart, and thin out to 6 ins. apart in the rows. As Spinach and the pure white stems can be cooked like Asparagus, affording two distinct dishes.

GLANT LUCULLUS. Grows to a height of 2 to $21 / 2 \mathrm{ft}$. with stalks thick as rhubarb and moss curled leaves; tender and delicious. Pkt., 10 cts.; oz., 20 cts.; $1 / 4$ lb., 60 cts.

GREEN LYON. Leaves can be cut repeatedly. "Cut-and-come-again."

Pkt., 5 cts.; oz., 15 cts.; $1 / 4$ lb., 50 cts.

\section{SQUASH}

One ounce will plant 25 hills

Succeeds best in rich soil. Do not plant before weather is settled; about May 2oth.

\section{EARL Y SUMMER VARIETIES}

EARLY SUMMER MAMMOTH WHITE BUSH, known as PATTY PAN. Plants are of bushy growth,bearing large fruits of superb quality. Plst., 5 cts.; oz., 15 cts.; 1// lb., 30 cts.

FORDHOOK. Excellent for Summer or Winter; ripens early and is one of the best keepers we know. Nearly bug proof. Skin smooth, flesh thick and extremely dry and sweet. Pkt., 5 ets.; oz,, 20 cts.; 1/4 lb., 60 cts. MINIATURE SPANISH CROOKNECK. It attains a length of I2 ins., is a fine keeper and of excellent flavor. Sweet and aromatic. Highly to be recommended. Pkt. 15 cts.

GIANT SUMMER CROOKNECK. Bush variety. Very early and prolific; fruit golden yellow. Pkt., 5 cts.; oz., 20 cts.; $1 / 4$ lb., 50 cts.

DELICATA. Early and very prolific; oblong shape. Shell creamy white, sometimes mottled green. Small sized but solid and heavy; while white, sometimes mottled green. Small sized but solid and heavy; while the quality is rich and dry. An excell

GOLDEN CUSTARD. 10 Similar to White Bush except in color, skin and flesh being creamy yellow. Pkt., 5 cts.; oz., 15 cts.; $1 / 41$ lb., 40 cts.

VEGETABLE MARROW. English grown but little known in this coun.

try. The fruits should be eaten when less than half grown, as the flesh is then very tender and marrowy. Pkt., 5 cts.; oz., 15 ets.; $1 / 41$ lb., 40 cts.

\section{AUTUMN and WINTER VARIETIES}

EARLY PROLIFIC or ORANGE MARROW. Fall sort excelling in earliness, prodủctivèness, and keeping qualities. Bright orange red. Flesh fine grained, dry and rich. Pkt., 5 ets.; oz., 15 cts.; $1 / 41$ lb., 40 cts.

THE DELICIOUS. One of the best for Winter use. Medium size, weight from 5 to Io lbs.; uniformly green shade. Flesh orange, very dry and delicious. Plkt., 10 cts., oz., 20 cts.; 1/4 lb., 60 cts.

BOSTON MARROW. Highly esteemed for Autumn use. Thin rind, reddish yellow. The best for canning and pies. Pkt., 5 cts.; oz., 15 cts. $1 / 4$ lb., 40 ets.

GOLDEN HUBBARD. Most popular Winter Squash. Flesh rich, fine grained and dry. Keeps throughout the Winter. Pkt., 5 ets.; oz., 15 $1 / 4 \mathbf{l b}, \mathbf{5 0}$ cts.

\section{TOMATOES}

One ounce produces about rooo plants

Sow thinly about first week in March in a hotbed or sitting room, where the temperature is never below 60 degrees. When 2 ins. high set out the plants in boxes about 4 ins. apart, or pot singly. About the first of June the plants may be transferred to the open ground. Set them deeply about $4 \mathrm{ft}$. apart; a shovelful of rotted manure should be mixed in the earth of each hill.

EARLIANA. The very earliest and best. very smooth and solid. Color bright scarlet. Try it and get results. Plxt., 10 cts.; oz., 50 cts.

DWARF CHAMPION. An upright growth, requiring the least support, even if loaded with fruits. Pink symmetrical Tomatoes of a firm, fine quality. Pkt., 5 cts.; oz., 35 cts.

ACME. Early. Very prolific. Crimson scarlet; smooth; fine flavor.

PONDEROSA. One of the best for home use. Vines are very vigorous; fruits oblong, growing in beautiful uniform clusters, some fruits weighing as much as one pound. Color a deep purplish crimson. It has a delicious as much as one pound. Color a deep purplish crimson. It has a delicious meaty flavor and many consider it the finest Tomato for slicing and
use as it has few seeds. Pkt., 10 cts.; $1 / 2$ oz., 40 cts.; oz., 75 cts.

LIVINGSTON'S GLOBE IDEAL. Rich and juicy fruits, large; fine for slicing; with a glossy skin of a vivid crimson, enchanting to the eye. Pkt., 10 cts.; $1 / 2$ oz., 40 cts.; oz., 75 cts.

NEW STONE. None better for canning owing to its keeping qualities and firm solid flesh. It ripens evenly and is thick and meaty to the core. A standard favorite praised by every grower. Pkt., $5 \mathrm{cts}$.; $0 z ., 30 \mathrm{cts}$.

GOLDEN QUEEN. Smooth, large golden yellow fruits. Fine flavor. Plkt., 5 ets.; $1 / 2$ oz., 20 ets.

LIVINGSTON'S CORELESS. Large size, globe shaped; a red Tomato that is a joy in the seeing and eating. Pixt., 10 cts.; $1 / 2$ oz., 40 cts. PERFECTION. Very early. Blood red, round and smooth; ripens uniformly and bears abundantly until frost. Pkt., 10 cts.; $1 / 20 z$., 40 cts.

\section{SMALL FRUITED TOMATOES}

RED CHERRY. Little fruits, bright scarlet. Plt., 5 cts.; oz., 30 cts. RED PEAR. Pkt., 5 cts.; oz., 30 cts.

YELLOW CELRRY PEAR oT PEACH. Pkt., 5 cts.; oz., 30 cts.

STRAWBERRY. Fine for sauce or preserving. Pkt., 5 cts.; oz., $30 \mathrm{cts.}$

\section{SUNFLOWER}

MAMMOTH RUSSIAN. May be grown to great advantage in waste ground. An excellent and cheap food for fowls. All farmers should ground. An if excellent and plant this, if only for feeding chickens. It is enormously productive of seed, as the heads sometimes measure I8 ins. in diameter. Plant 4
quarts to acre. Lb., 25 cts., postpaid. By express or freight, at quarts to acre. Lb., 25 cts., postpaid. By express or freight, at
purchaser's expense. 'Pk., 60 cts.; bus., (25 lbs.) $\$ 2.00 ; 100$ lbs., $\$ 7.00$.

\section{BIRD SEEDS}

CANARY SEED ........Lb., \$0.15 TAPE..............Lb., \$.15 MILLET, American....Lb., $\quad .10 \quad$ PARROTS..........Qt., $\quad .15$

\section{SWEET POT AND MEDICINAL HERBS}

These are indispensable for every home garden. For flavoring soups, meats, etc., for medicinal use (especially where there are children), some good herbs will be found most useful.

Culture. - All herbs thrive best in rich, mellow soil. Sow the seed early in spring in shallow drills one foot apart; when the young plants are up to 2 to 3 ins. thin out or transplant. Cut on a dry day before coming into full blossom, tie in bunches and hang where they dry rapidly.

ANISE SEED. Very aromatic. Fine for flavoring cakes, etc. Pkt., LAVENDER. Sweet Lavender, for perfumes, oils, and toilet waters. 5 cts.; oz., 20 cts.

BALM. For Culinary purposes. Pkt., 5 ets.; oz., 25 cts.

BORAGE. Grand as a salad mixed with lettuce. Flowers are excellent for bee pasture. Pkt., 5 cts.; oz., 10 ets.

BASIL, SWEET. For flavoring soups, pickles, etc. Plrt., 5 ets.; oz., 15 cts.

CARAWAY. Good in soups, bread, liquors, etc. Plst., 5 cts.; oz., 10 cts.

CATIIP. Have you a pussy? She will need this herb to keep in good health. Also fine for medicinal tea. Pkt., 10 cts.; 0 z., 40 cts. CORIANDER. Fine for flavoring. Pkt., 5 ets.; oz., 10 ets.

DILL. For flavoring pickles, vinegar, etc. Pkt; 5 ets.; oz., 15 cts. FENNEL. Sweet, for flavoring sauces. Very aromatic. Pkt., 5 ets.; HOREHOUND. Great cough remedy. Pkt., 5 cts.; oz., 25 cts. Delightful placed between linen. Pkt., $\mathbf{5}$ cts.; oz., 20 cts.
MaRJoRAM. One of the best known herbs for seasoning. Pls $\mathbf{5}$ ets.

MINT, PEPPERMINT. Who does not know lamb with mint sauce or mint julep? Get yours fresh instead of stale in the markets. Fkt. 25 ets.

ROSEMARY. Yields a very aromatic water and oil. Pkt., 10 ets.; OZ., 30 cts.

SAVORY. Summer, used in kitchen for flavoring. Pkt., 5 ets.; oz., THYME. Broad English. Indispensable for seasoning. Pkt., 5 cts.; oz., 25 cts.

WOODRUFF (Asperula odorata). A delightful aromatic herb used largely to flavor wine, punches, etc. Pkt., $10 \mathrm{ets.;}$ oz., $50 \mathrm{cts}$.

\section{OUR \$1.00 HOME-GARDENING VEGETABLE COLLECTION}

Every one with a few square feet of ground can contribute to victory by growing vegetables. It saves money; it helps lower the

"High Cost of Living." It is a patriotic way of "doing your bit."

BEANS, I pkt. Early Wax.

BEANS, I pkt. Green Podded.

BEETS, Early Blood Turnip.

CARROTS. I pkt. Early Chantenay.

SWEET CORN, Stowells Evergreen, $1 / 2$ pt. CUCUMBER, I pkt. Davis perfect.

LETTUCE, I pkt. May King.

PEAS, I pkt. medium.
PARSNIPS, I pkt. Hollow crown. RADISH, I pkt. Coopers sparkler. RADISH, I pkt. Olive shaped. TURNIP, I pkt. Early Snowball.
SQUASH, I pkt. Early Summer. 


\section{JAPANESE VEGETABLES}

The Japanese as a nation are almost entirely vegetarians. Very little meat is used by the general public, their food consisting of fish and vegetables. They are also known as most expert gardeners and their vegetables attain a perfection of growth and flavor which must be tasted to be appreciated. We give herewith a list of the best, al! having been tested by the Department of Agriculture and recommended by that body as being h ghly suited to the divers climates of the United States.

\section{RADISHES}

SAKURAJIMA. A Japanese Radish which grows to immense proportions. Picture to yourself a pure white Radish, the size of a baseball, firm and solid. Cut it, and you find that it has the consistency of a Baldwin Apple, firm and fine of grain. Taste it and it proves to be ahead of the Taste it and it proves to be ahead of the best Spring Radish that ever passed your lips. It will thrive at any season during the growing year; may be transplanted of left to itself; cultivated or uncultivated. it is as good to eat when in bloom as in its younger days, and one Radish will proride bulk enough for three or four people. Need more be said? This Radish forms its fruits later than other Radishes. If sown in Fall the fruit will be best in early Summer, but if sown in Spring it will not be ready till late Fall Trial pkt. 10 cts.; $1 / 2$ oz., 20 ets.; oz., 30 ets.; $1 / 4$ lb., 75 cts.

MIKADO. This grows to a length of I2 in. by 3 to 4 in. in circumference. The flesh is pure white and of the greatest sweetness and delicacy of flavor. It never grows pithy. Finer than Icicle or Lady Finger. Try it. Pkt., 10 cts. $1 / 20 z ., 20$ ets.; $0 z_{.,}, 30$ cts.

BOTTLE RADISH. Succeeds in the poorest soil. The quality is second to none. Mild and delicious in flavor. We recom mend it for successive sowings. P
10 cts.; $1 / 2$ oz., 20 ets.; oz., 30 cts.

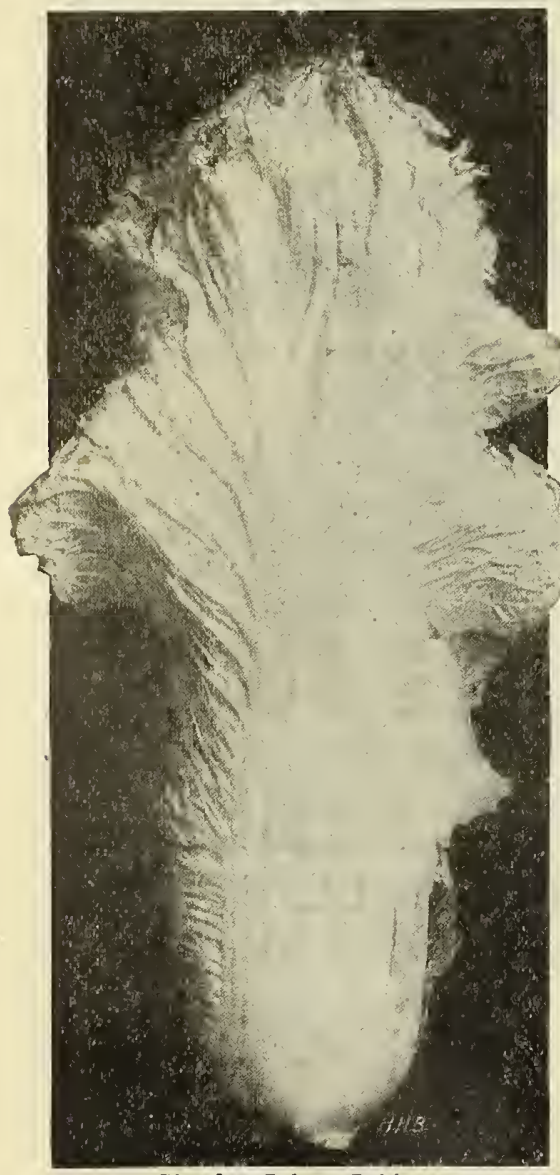

Cheefoo Celery Cabbage

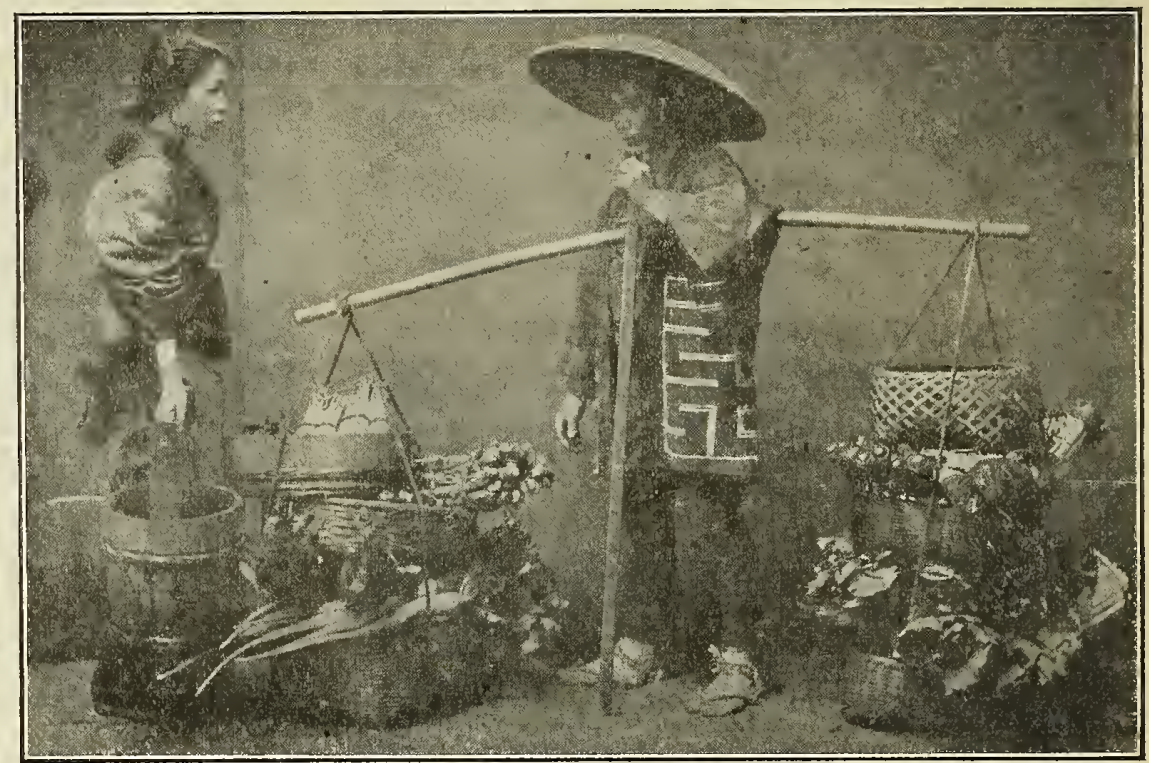

NERIMA. A very handsome Radish. The quality for eating, firmness and flavor are excellent. 2 to 3 ft. long, 8 to Io in. circumference. Pkt., 10 cts.; $1 / 2$ oz., 20 ets.; oz., 30 ets.

\section{CABBAGE}

CHEEFOO or CHINESE WHITE CABBAGE. Similar to Celery Cabbage but the heads are larger and more round. A true and valuable type. Firm, tender and white. Splendid cooked in almost any manner. Pkt., 10 ets.; $1 / 2$ oz., 20 cts.; oz., 30 ets.

COREAN PE TSAI. Large oblong form, well curled; delicate midribs merging into crisp, tender leaves at the top. Extremely delicious. Pkt., 10 cts.; $1 / 2$ oz., 20 cts.; oz., 30 cts.

CHIRIMEN PE TSAI. Small well curled heads of lustrous fresh green color. Crisp, tender, delicate rich. It equals any of our home grown varieties. A Cabbage "Pearl." Pkt., 10 cts.; 1/2 0z., 20 cts.;, oz., 35 cts.

\section{EGG PLANT}

Japanese Egg Plants are small in growth, but the delicacy of their flesh will entice any one giving them a trial to consider them a necessity for the vegetable garden. They are far superior to the larger sorts.

YAMANASU. I Round. Color dark purple. Extremely prolific and robust. Sweet flavor. Pkt., 10 ets.

OBLONG. I to $2 \mathrm{ft}$. long. Shining purple black in color. Flesh very tender and delicate and highly flavored. Pkt. 10 cts.

\section{CUCUMBERS}

JAPANESE CLIMBING. So well known it hardly needs any description. While all Cucumbers are creeping vines this variety climbs readily and may be grown on trellises, stakes, or fence, in fact, on
any support. Extra fine for small gardens, requiring little space. It bears abundantly throughout any support. Extra fine for small gardens, requiring little space. It bears abundantly throughout
the season and one vine will keep a family supplied throughout all Summer. Fruits are thick and oblong; the flesh pure white; the skin dark green, bronzing when ripe. Pkt., 10 cts.; oz., 20 cts.

KONOMON. Most delicious and fine flavored. Fruits long; thick flesh, white outer skin dark rich green. Pkt., 10 cts.; $1 / 2$ oz., 20 cts.; oz., 35 cts.

\section{GARROTS}

KINTOKI. Best scarlet; early half long; sugary and tender. Pkt., 10 cts.; oz., 25 cts.

SAPPORO. A long variety; very sweet; color deep orange. Pkt., 10 cts.; oz., 25 cts.

\section{JAPANESE LEEK}

NEBUKA. A most tender and deliciously flavored Leek. Delightful in its young state as a salad or eaten raw; it lacks the strong taste so undesirable in young Onions or Leeks. Sweet and ap petizing. Plst., 10 cts.; $1 / 2$ oz., 30 cts.

ONION 'OMI. A very delicate, smooth, white skinned sort. The flavor is most appetizing. Much used in Japan in its young state, when it can be eaten raw. Is a good keeper and in every way desirable. Pkt., 10 cts.; $1 / 2$ oz., 30 cts. 


\title{
JAPANESE VEGETABLES-Continued
}

\section{JAPANESE MUSKMELON}

BINIMAKUMA. Melts in your mouth. In growth and appearance , slightly resembling the Nutmeg. Melon. The flesh is golden yellow, aromatic, fragrant, sweet and delicious. Pkt., 10 ets.; 1/2 oz., 25 ets.; oz., 40 ets.

\section{SQUASHES and PUMPKINS}

PUMPKINFCHIRIMEN. Unsurpassed in flavor. A mine of sweetness for pie filling. Fruits are large, round and "Oh, so tender!" Just try it once. Pkt., 10 cts.; $1 / 2$ oz., 20 cts.; oz., 30 cts.

EARLYSWEET KIKUZA. This is a small, sweet pumpkin, round, flattened shape; very fine grained, sugary and rich. Pkt., 10 cts.; $1 / 2$ oz., 20 ets.; oz., 35 cts.

KIKUZA. Medium in size, solid and of excellent quality. Flesh salmon yellow. Pkt., 10 cts.; $1 / 2$ oz., 20 ets.; oz., 35 cts.

\section{TURNIPS}

TEN OJI. Weight 6 to 8 lbs. Large; snow white flesh; crisp and juicy. Pk t., 10 ets.; $1 / 2$ oz., 20 cts.; oz., 35 cts.

MAMMOTH SHOGOIN. Excellent for the table. Like the Sakurajima

Radish this Turnip attains large proportions without impairing the sweetness of its flavor and the delicacy of grain and taste. Ripens early and is a splendid keeper. Invaluahle for home and farm. Pkt., 10 cts. oz., 30 ets.

JAPANESE MUSTARD. Color a deep green. Flavor pleasant, sweet and pungent. Fine for seasoning roasts. Pkt., 5 cts.; oz., 15 ets.

JAPANESE PEPPER. Very piquant and prolific. Long slim fruits of sweet 1 flavor. Pkt., 10 cts.; $1 / 2$ oz., 25 cts.

\section{JAPANESE PEAS}

These are gaining steadily in favor. Orders have grown steadily from eason to season, these sorts having been found especially productive, extremely hardy and well flavored.

AO-DAIDSU. Extra early. Broad dark green pods, filled with delicious peas. One of the best.

YENDO. A standard Japanese sort. Peas are wrinkled, sweet, large, and bear in abundance.

AO-SHIRA-DAIDSU. One of the best round seeded varieties. A splendid pea, bearing a large crop of lightly curved pods filled with 7 to 8 large round green peas.

SA YA-ENDO. Edible podded peas. Can be cooked and eaten like String Beans. Pkt., 10 ets.; $1 / 2$ pt., 30 cts.

\section{JAPAN RUNNER BEAN}

(Pole Bean)

This has been acknowledged by customers who gave it a trial as a most delicious and desirable sort. The single pods attain a length of nearly 3 feet and are deliciously sweet and crisp, entirely stringless The bean itself is small, light brown. Trial pkt., 10 ets.

\section{JAPAN BEANS}

Mellow, delicious, all of the bush variety. Highly productive and of the easiest cultivation. Require a rich, mellow soil and good drainage. Give them a trial.

CHAIN-GEM. Large, flat, bean, light brown color. Pkt., 10 ets.; pt., 35 ets.

HIRA-MAME. Large black bean. Pkt., 10 ets.; pt., 35 ets.

MIDSURA-INGEN. Speckled large bean. Pkt., 10 ets.

SARASA. Similar to our Kidney Beans. Tender and fine eating. Pkt., 10 ets.

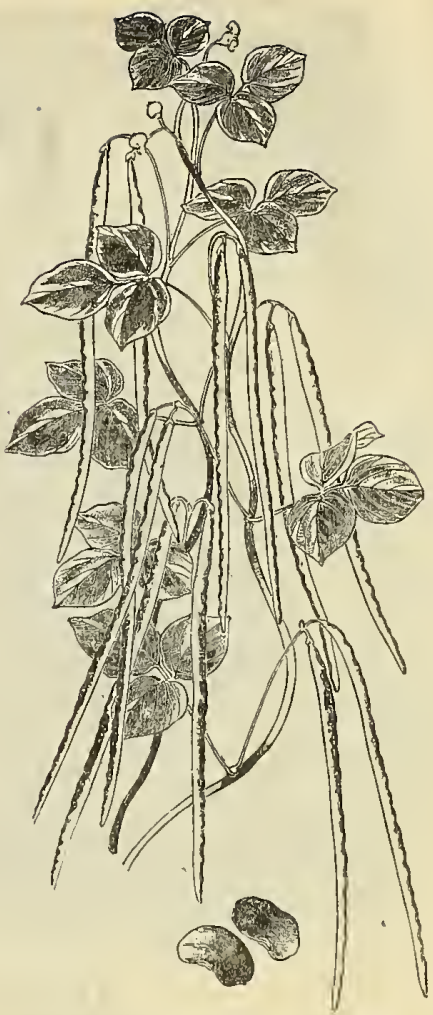

New Japan Long Runner Bean

SORA-MAME. Large flat, brown Bean. When cooked, like the most delicious Lima Bean.

TWANAI. A fine speckled sort.

WHITE INGEN. Most tender and productive.

Any of above, price per pkt., $10 \mathrm{cts}$.

\section{THE UDO SALAD SEED (Novelty)}

This plant was first introduced as a vegetable in American gardens in 1902 , and has proven hardy and vigorous over a wide extent of country, reaching as far north as Nova Scotia, and in New England, especially in Maine and Connecticut, it has made remarkable growth. At Arlington, Va., plants have made from seed in a single year a growth of over six feet and a splendid root system.

Udo differs from Asparagus in that while only the tips of Asparagus are edible, the whole of the long Udo shoots are tender and stringless.

Planted in a bed it will yield crops for eight to ten years, producing delicate white shoots.

There are three ways to prepare Udo. First, as a soup in which the end of the shoots are used as is Celery root and with the same method of preparation. Second, cooked and served with a white sauce on toast, in the same way that Asparagus tips are cooked; and third, sliced thin like shavings, dropped on ice and later seasoned with French dressing.

Seed, per pkt., 25 ets.; trial pkt., 10 ets.

\section{SPEGIAL NOTICE}

To induce our customers to give the Japanese Vegetables a chance to show how delicious they are, we have arranged to distribute TRIAL Packets of any seed listed in Japan Vegetable section at $5 \mathrm{cts}$. each.

12 packets of difierent sorts for 50 cents

\section{CHEEFOO or CELERY CABBAGE}

\author{
See illustration, page 8
}

The picture taken from a photo from nature shows this new delicious vegetable, which combines the rich celery flavor with that of the cabbage.

\section{THE BEST THING OUT}

No other cabbage compares with this for cold slaw. Makes as good salad as the finest head lettuce, Excellent when boiled with meat or for vegetable soup. Good in oyster stews, better than the oysters. Eaten raw like celery. The midribs may be cooked like asparagus. The leaves are used for all above described.

It is a dish fit for a king.

Pkt., 10 ets.; 1/2 oz., 35 cts.; oz., 60 cts.

Sow the seed in early spring in rows 15 inches apart; when the seedlings are strong enough, thin out the young plants to 6 inches apart in the row. Keep free from weeds. 


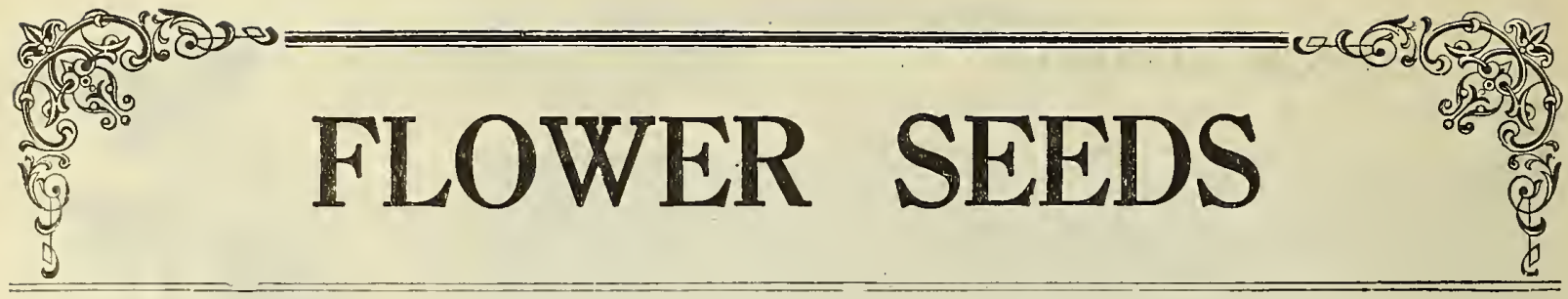

\section{ANNUAL FLOWERS}

Are one summer season's gay floating banners. Can be sown early in the house to obtain very early bloom, or right outdoors where they will bud, bloom, and die when frosts appear. They are like butterflies gaily swinging in the sunshine and disappearing with the cold winds. They ripen their seeds before dying, leaving a memory and a promise for the coming year. Many are self sowing and wherever they blossomed one the rollowing.

Half Hardy Annuals are more tender than the hardy sorts. The half hardy sorts, to secure early bloom, must be sown in either a hotbed or in boxes in the house early in season, January to March. We designate in the following list only the Half Hardy Annuals all $_{\mathrm{w}}$ others being Hardy Annuals.

We recommend sowing of Annuals especially where one season's flowers are desired, for instance: in rented homes, near the seaside, or wherever seasons are short.

Per pkt. charring umbels, very est soil, loves sunshine, needs but little moisture. Ht., 4 inches Oz., 30 cts. $\$ 0.10$

\section{AGERATUM Half Hardy}

A very popular bedding plant, covered throughout the season with delicate feathery blooms, in umbels, completely hiding the foliage. Must be sown indoors for early bloom. Sown out-of-doors the plants would not come into flower till late summer. The dwarf sorts are especially not come into flower till late summer. The dwarf sorts are especially
desirable for edging or carpet bedding, the tall sorts are unequalled for bouquets, etc.

Ageratum Mexicanum, Tall blue. Ht., $1 \frac{1}{2}$ feet. $1 / 4$ oz., 20 cts. Pkt.

Tall white. Ht., $1 \frac{1}{2}$ feet. . . . . . . . . . . 1/4 oz., 20 cts... . 05

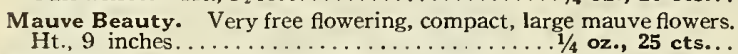

Swanley. Blue, dwarf, very fine Ht. 9 inches $1 / 4$ oz 20 cts.

Dwarf white. Ht. 9 inches.......... oz., 20 cts.

Little Blue Star. Miniature plant, completely hiding foliage with a mass of small mauve flowers. Beautiful for edging,rockwork, etc. Ht. 5 inches.......... Trial packet 10 cts.

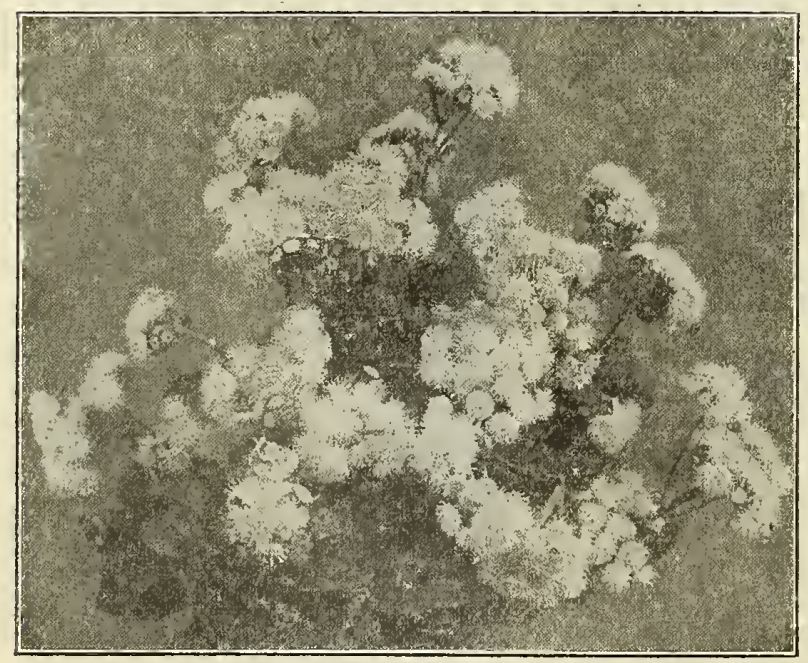

Ageratum, Dwarf. Little Blue Star
ADONIS AESTIVALIS (Flos Adonis). Foliage finely cut, brilliant scarlet flowers. Does well in partial shade and can be sown successfully in any corner of the garden. Ht. $1 \mathrm{ft} . \ldots \ldots \ldots$. Oz. 50 cts...

AMBERBOA MURICATA ROSEA. A beautiful Hardy Annual. On stems two feet long, the light rosy pink cornflower-like blossoms are produced in great numbers throughout the season. Fine for cutting, last a long time kept in water.. Trial packet 10 cts.. .

Plt. .10

\section{ALYSSUM}

One of the very best and most useful annuals. Invaluable for cutting; extensively used as border plant, for rockwork, bedding, etc. Flowers incessantly from early summer till latest fall.

Benthami (Sweet Alyssum). Flowers honey sweet-scented, pure white. 10 inches.......... Oz., 30 cts.; 1/4 lb., \$1.00 .....

Little Gem. Dwarf, white. 4 inches......... Oz., 75 cts... 05

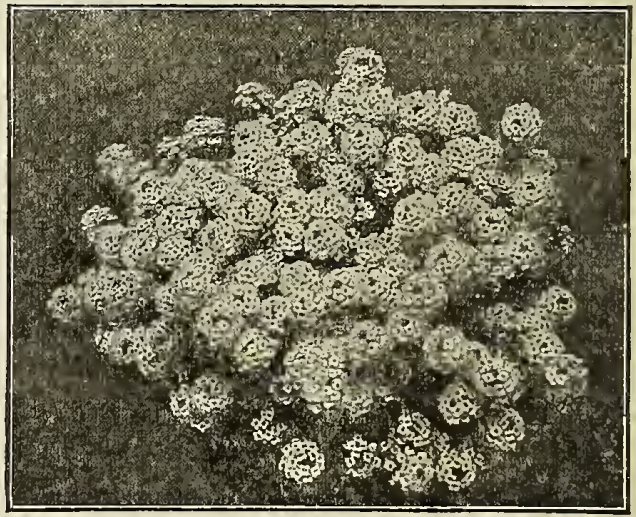

Sweet Alyssum Little Dorritt

Little Dorritt. This new sort forms a perfect little bush with masses of purest white flowers. A gem for edging. 4 to 5 inches. Oz., 75 cts... Carpet of Snow. Very dwarf, attaining 3 to 4 inches. Profuse bloomer, deliciously fragrant................., 65 cts...

\section{AMARANTHUS $\underset{\text { Annual }}{\mathrm{Half}}$}

Very showy annuals. The brilliant foliage is most effective in borders, and in subtropical gardens. Fine for decorations.

Caudatus (Love Lies Bleeding). Drooping crimsón flowers in racemes. 3 feet..................... 25 cts...\$ . 05

Cruentus (Prince's Feather). Dark red........ Oz., 25 cts... 05

Melancholus ruber. Rich bright red. $I \frac{1}{2}$ feet...Oz., 50 cts... 05

Salicifolius (Fountain Plant). Graceful long undulating foliage marked carmine, orange and bronze. 4 to 6 feet. Most beautiful ............................ 40 cts...

Tricolor (Joseph's Coat). A grand ornamental foliage plant. The leaves are beautifully marked orange, scarlet, crimson, bronze,

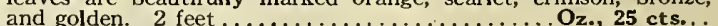
All sorts mixed ....................., 25 cts... .05

ANCHUSA CAPENSIS (Cape Forget-me-not). A charming annual with azure blue flowers. $1 \frac{1}{2}$ feet. May be likened to a Giant Forget-me-not ....................1/4 oz., 25 cts...

BOCCONIA JAPONICA (Plume Poppy). Ht. 6 to 8 feet. Tall flower stems, with terminal panicles of creamy white flowers. Large glaucous leaves. Very useful for background in large borders or beds . ...................... 40 cts. 5 


\section{ASTERS}

These are the favorites of Autumn, glorifying with their ideal beauty the last days of golden Summer. They stand in rows like ballet dancers in gaudy skirts in all the colors of the Rainbow. Seemingly so fragile, yet SO HARDY.

One of the very easiest flowers to cultivate, and one of the MOST grateful.

Their great advantages are:

1. They can be had in flower throughout the whole summer till killing frosts come to us.

2. They represent every color and shade known to painters' brush.

3. They last for many days when cut, especially in bud, and are one of the most decorative flowers known.

4. There is ONLY one Insect enemy which attacks Asgers. You surely are acquainted with the ugly black beetle that feeds on your promising Aster buds, but you need not mind if you will spray your plant once a week with "APHINE" (See Insecticides Page).

Apply Vermine to the soil while the young plants stand yet far apart. Give enough to penetrate the soil. It will kill all Inseet Marauders.

\section{NOVELTIES FOR 1918}

Cactus Aster Rosy Dawn. A brilliant rosy tine. Blooms early. Pkt., 20 cts.; 2 pkts., 35 cts.

PINK BEAUTY. Variety of strong, free growth Upright, bears on its branches often as many as 40 to 50 flowers at one time. Stems are long and stout. Color a delicious soft blush pink. Pkt., 20 cts.; 2 pkts. for 35 cts.

SNOWDRIFT. Immense feathery white flowers, most graceful and attractive. Pkt., 15 cts.; 2 pkts. 25 cts.

AUTUMN GLORY. A very late Branching Aster pure seashell, pink, Very double and borne on long, strong stems. Pkt., 20 cts.; 3 pkts. for 50 cts.

3 pkts. for 50 cts.
SOUTHCOTE BEAUTY. A flower so perfect and beautiful that wherever it is seen it elicits universal admiration. Each flower has long, perfectly formed petals with a small golden center. 15 to 20 inches high. Stems are long and stiff and are unrivalled for cutting. Pkt., 15 cts.; 2 pkts. for 25 cts.

DAYBREAK. Flowers of great substance, last a long time after cutting. Color a soft shell pink to pale rose. Pkt., 15 cts.; 2 pkts. for 25 cts.

BLUE BIRD. 25 A rare blue tint. Same character as Daybreak. Plkt., 25 cts.

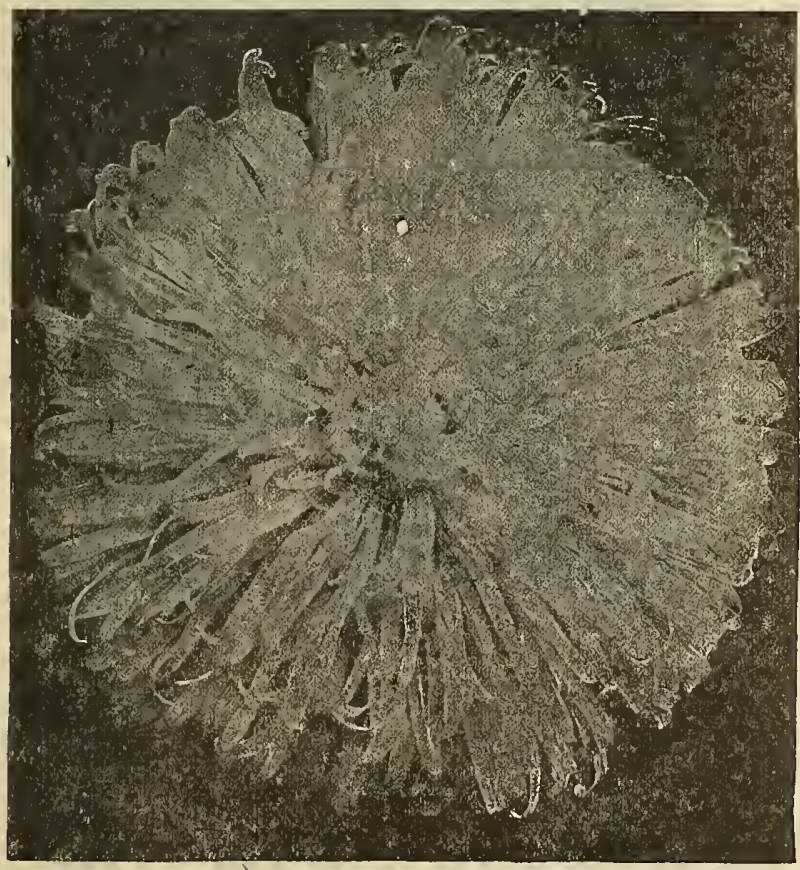

Aster-Mammoth Mauve Queen

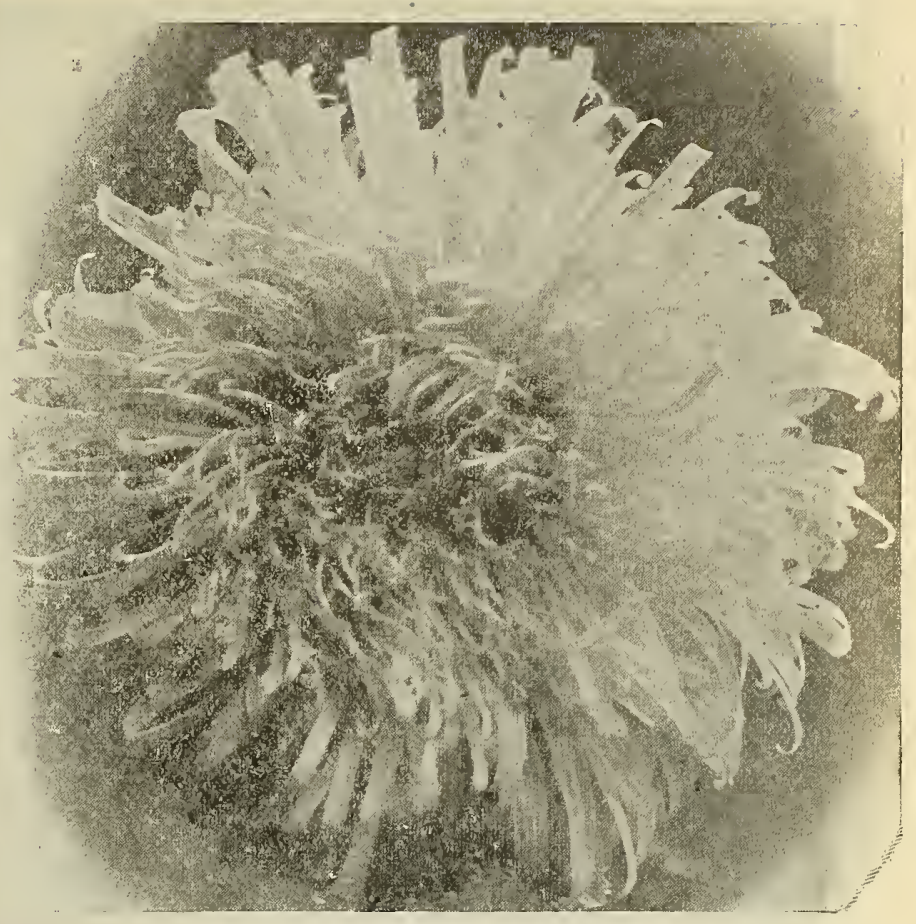

Noble Aster

Per pkt.

Cactus Aster Celestine. Early flowering, with narrow petals nearly 2 inches long, twisted at the end, resembling the Cactus Dahlias. a few inches above the ground, throwing out 15 to 20 strong side shoots covered with bloom. A grand acquisition. .3 pkts., 40 cts.. $\$ 0.15$

Hercules. Brilliant rose. Flowers perfectly curled and waved, 5 to 6 inches across. Flowers borne on thick, strong stems, ht.,

16 to 20 inches. This is one of the most perfect Asters grown.
$\mathbf{3}$ pkts., $\mathbf{4 0}$ cts...

Noble Aster. Pure white, indescribably beautiful, curled and twisted like a Cactus Dahlia, very long stems, large flower.

$1 / 8$ oz., $\$ 1.00 \ldots .15$

Lavender Gem. Blooms in midseason. Flowers a soft charming shade of lavender, resembles a beautiful Chrysanthemum. Be-
longs to the Ostrich Plume type...............1/8 oz., $\$ 1.00$. .

Miss Roosevelt. A beautiful new Victoria Aster. Flowers are a clear primrose tint changing to a delightful flesh color. A splendid flower for decorating, showing brilliantly under artificial light.

$1 / 8$ oz., 75 cts.

Triumph of Paris. Flowers $4 \frac{1}{2}$ to 6 inches across, with long, pure white outer petals, in centre of which the quilled disk florets form a bright golden wreath...................... oz., $\$ 1.00$. .

MAMMOTH MAUVE QUEEN. The unique color of this variety is best described as a rich pearl gray, or the color of Sweet Pea Counbest described as a rich pearl gray, or the color of Sweet Pea Coun-
tess of Radno: The flowers, as picture shows, are of perfect form, tess of Rable, ${ }^{2}$, The flowers, as picture shows, are of perfect form, White Mikado. Large, shaggy, white flowers formed of petals
twisted and curled like the most beautiful Chrysanthemum. The plants are of spreading habit similar to branching sorts. One of the earliest midseason Asters................1/8 oz., 75 cts...

Pink Mikado. The most enchanting shade of true shell pink. Petals are long, narrow, reflexed, curling across each other; in fact,
the fluffiest Aster. we know. Growth very vigorous, remarkably the fluffiest Aster. we know. Growth very vigorous, remarkably
free from disease............... 75 cts..

Toison d'or (Golden fleece). In this grand novelty has been found the color so long wanted amongst Asters. It is the most striking brilliant yellow color, perfect in form and habit.Trial pkt., $10 \mathrm{cts}$. .

Violet King. The peer of the grandest Chrysanthemum. Petals large and broad, completely covering the crown. Bloom is round, full and large; color is the most soft violet lilac....1/8 oz., $\$ 1.00$. . 


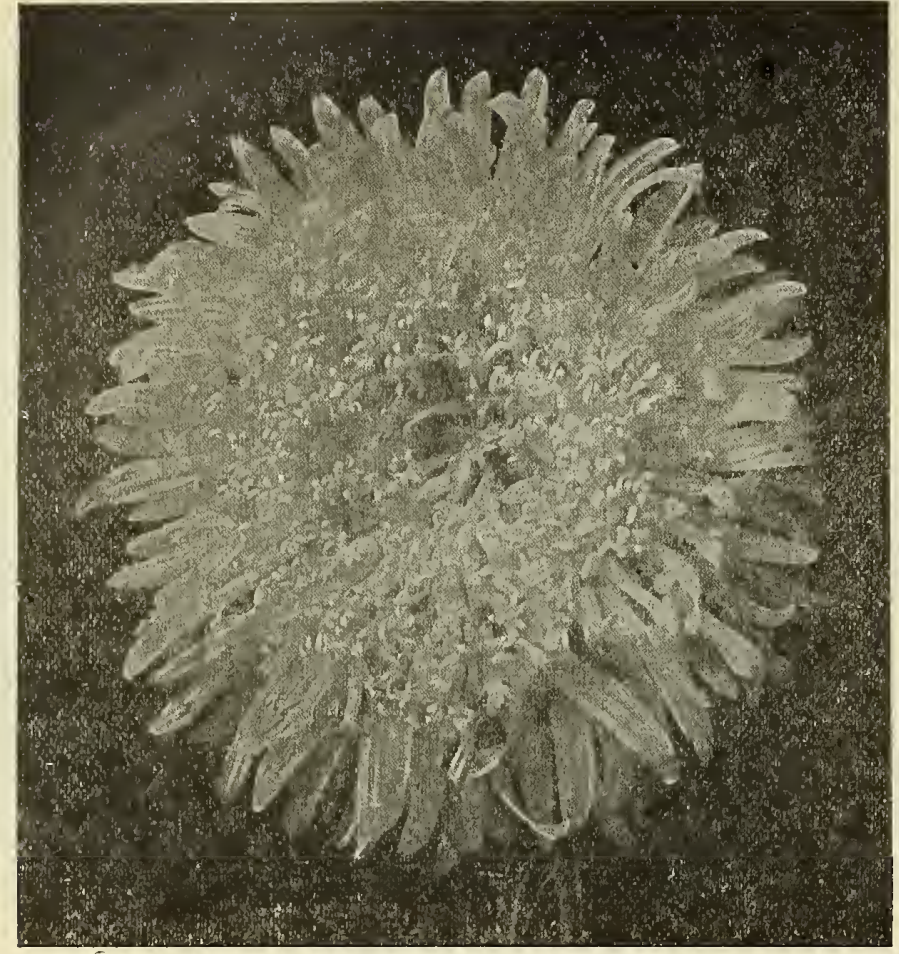

\section{MIDSUMMER VARIETIES OF ASTERS}

Truffeaut's Preonia-flowered. Exceptionally large blooms, freely produced on stems 18 to 20 inches long. Branching habit. Bloom in August. This sort produces the finest incurved bloom, globular form 3 to $3 \frac{\pi}{2}$ inches in diameter. One of the finest Asters. We furnish this sort in following separate colors: White, Light Blue, Dark Blue, Rose, Shell Pink, Crimson, Fiery Scarlet.

$1 / 4$ oz., $\$ 1.00$; 1/8 oz., 60 cts...

Mixed Shades........oz., $\$ 3.00 ; 1 / 4$ oz., $\$ 1.00 ; 1 / 8$ oz., 50 cts.. . . In

Hohenzollern or Ostrich Plume. A beautiful variety with long wavy petals of greacful form. Invaluable for cutting, of a particularly pleasing character. We offer in following assortment of separate colors. Pure White. Shell Pink, Light Yellow, Rose, separate colors. Pure White, Shell Pink, Light Yellow, Rose, $1 / 4$ oz., $\$ 1.25$; $1 / 8$ oz., 80 cts.;..

New Giant Comet. Most beautiful elegant flowers with long wavy and twisted petals like Japanese Chrysanthemums. They are and twisted petals like Japanese Chrysanthemums. They are magnificent used for table decoration when cut. They are long stemmed, of perfect habit. We offer in following, separate colors:
White, Flesh Color, White passing to Light Blue, Rosy Lilac, Azure, Blue, Dark Blue, Peach Blossom. Crimson, Deep Rose, Rare Light Yellow. ...........1/4 oz., \$1.00; 1/8 oz., 60 cts..

Mixed colors................1/4 oz., 85 cts; $1 / 8$ oz., 50 cts...

Victoria Improved. Enormous flowers very double, beautifully recurved petals. A truly Queenly Aster. 2 feet high. We offer the following separate colors: White, Light Blue, Dark Blue, Apple Blossom, Salmon Pink, Peach Blossom, Royal Purple, Fiery Scarlet................1/4 oz., $\$ 1.00 ; 1 / 8$ oz., 50 cts... Mixed Shades................1/4 oz., 85 cts.; $1 / 8$ oz., 45 cts.

We also can furnish Dwarf Victoria Asters in all shades of the Victoria at same price. These attain a height of 10 inches.

\section{CREGO ASTERS}

This class of Asters is so unique that we feel it should have a section all to itself. Of free, sturdy growth, attaining a height of 2 to $2 \frac{1}{2}$ feet The foliage a glossy green, the branches bearing literally in masses the most graceful fluffy flowers rarely less than 4 inches across, as beautifu as the most exquisite Chrysanthemum, keeping in good condition longer than any other Aster of this type. Blooms August to late frosts.

Crego Giant. Pure glistening white.........1/4 oz., \$1.00. $\$ 0.10$ Crego Giant. Lavender. ..............1/4. $\$ 1.00 .10$

Crego Giant. Rose-pink. Of the most charming shell-pink. These three shades planted and blooming together on one bed offer picture and color effect of entrancing beauty.....1/4 oz., $\$ 1.00 \ldots . .10$ Crego Giant. Mixed..................1/4 oz., 75 cts... . 10

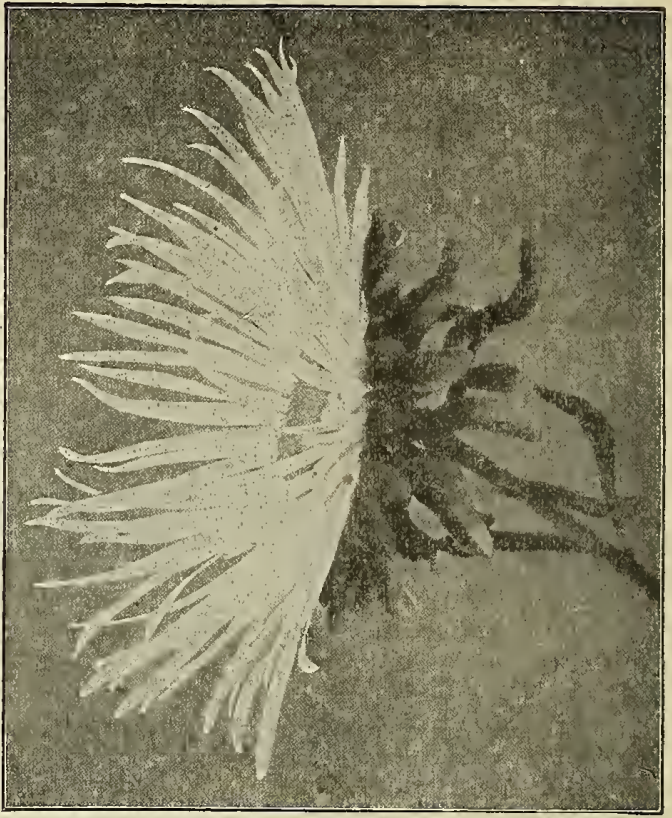

\section{SINGLE ASTER - JAPAN STAR}

Large, star-shaped single flowers. A rival to the beautiful single flowering Japan Chrysanthemums. The small central yellow disk is surrounded by a wreath of long, quilled ray petals or florets, lending the flower an uncommonly bizarre and graceful effect. The plants are very hardy, of branching habit, throwing a quantity of strong side stalks right up from the main stem. For cut flowers these blooms are unique, lasting for many days in water. They flower early, lasting all through summer and far into fall until late frosts kill them. Ht, $2 \mathrm{ft}$. One of the greatest Novelties of 1914 Pure white or rose, each ......... Trial pkt., 10 cts.; pkt., 20 cts.

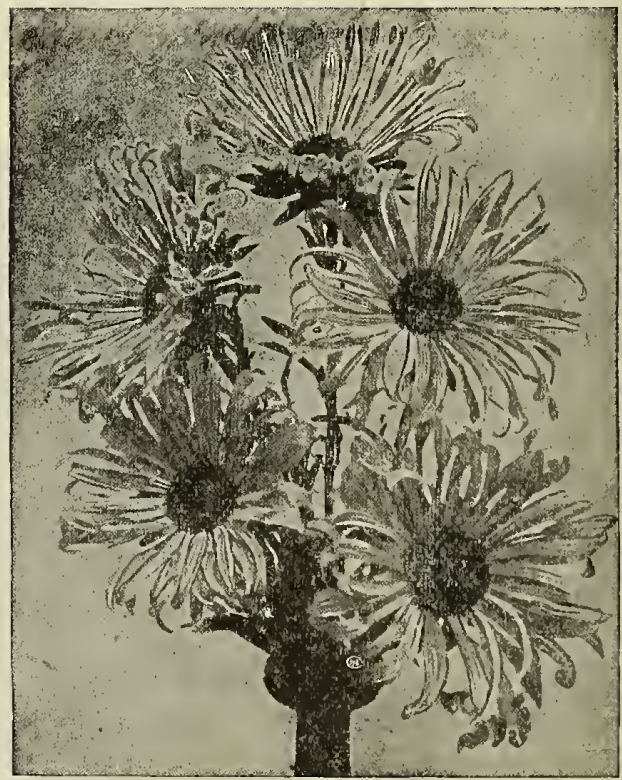

\section{ASTER ELEGANCE}

The most beautiful strain of single Asters ever introduced. Un- Pkt. surpassed as a bedding variety of striking, showy appearance; preferred by many to the showiest double Aster on account of their chaste beauty, and their great value as cut flowers. Plants are tall, 2 teet, and more, very vigorous, free from disease, the foliage is long, elegantly waved and the single flowers borne on long, erect stems. Petals are beautifully twisted. Pure White, Soft Lavender, Deep Rose. Separate colors $1 / 8$ oz., 50 cts. . . . . . . . 10 


\section{ARGEMONE PLATYCERAS}

This is the true Argemone platyceras. The elegantly pinnated foliage which is of a bluish hue is extremely attractive. The glorious snow white silky shining flowers remind one of the Romneya Coulteri, but are not as flat as these, standing out boldly from the foliage. Sown early, the Argemone Platycera blooms the first season beginning end of June and remaining in flower for a long time. A sandy soil is preferred and a sunny position suits it best. Ht. $3 \mathrm{ft}$. and more. It is a perennial and only in very cold and exposed positions does it need winter protection. Cover with dry leaves or litter. Trial pkt., 10 ets.; larger pkt., 25 ets.

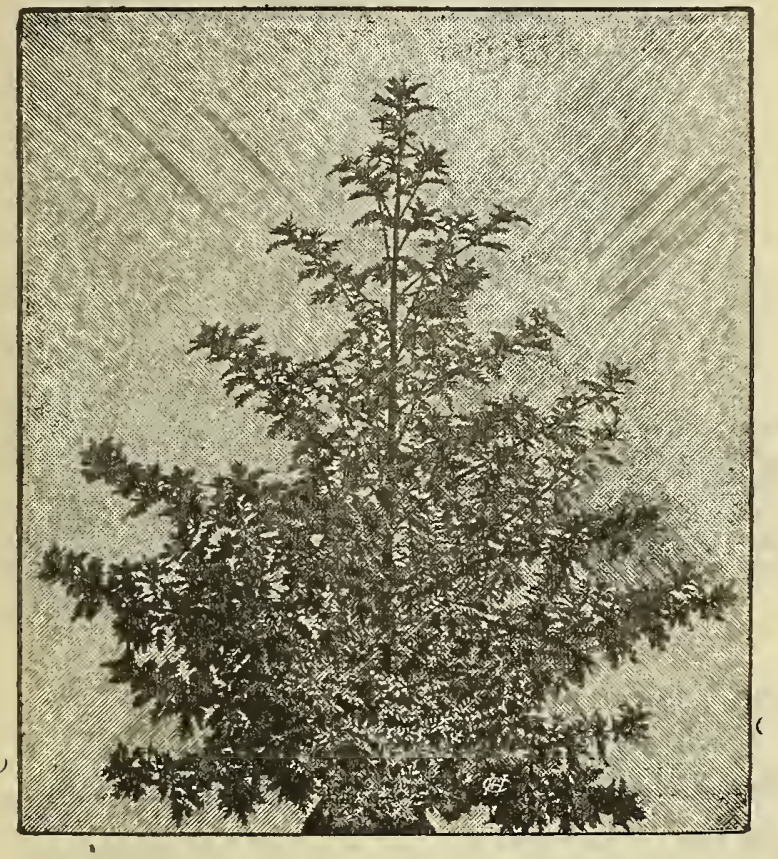

\section{ARTEMISIA SACRORUM VIRIDIS}

Summer Fir

An invaluable foliage plant introduced from China. Is an Per but owing to its phenomenal rapid growth, reaches its full size in one season, forming grand pyramidal bushes 4 to 5 feet high. Standing by itself it resembles a very nicely grown christmas tree. It also makes a most attractive pot plant. It looks superb when grown in groups a most attractive pot plant. It looks superb when grown in groups
or along walks and borders similar to Kochia Tricophylla the Summer Cypress. The color of the finely pinnated foliage is dark green. It is absolutely insensible to heat and drought. Several degrees of frost do not harm it. The plant grows anywhere and is of the easiest

culture ...........................................\$ $\$ 0.10$

Here is"a letter written us by a customer in Chicago:

I ordered in 1913 some seed of your Artemisia sacc. viridis. It turned out to be one of he prettiest things I ever saw. A shrublike herbaceous plant with beautiful fine foliage, something like Kochia, but not so bushy and vastly more beautiful. It has a fine Lemon Verbena-like odor, that is really exquisite.

Dr. W. W. S.

ARCTOTIS GRANDIS (Half Hardy Annual). 2 feet. A uniquely beautiful species from southwest Africa, whose charm is as yet not sufficiently known. The plant is of branching habit, with very pretty grayish foliage, the flowers are daisy-like, large, on long stiff stems rising well above the plant. The individual blooms are white petalled, the centre showing a narrow yellow ring, surrounded with a bright lavender blue disc. So distinct that folk never pass it by. Grows anywhere. It is very showy and invaluable for cutting, lasting long in water.......1/4 oz, 35 ets.

Mixed. The collection of 5 sorts for $\mathbf{4 0}$ cts..

Aloysia citriodora (Lemon Verbena). Perfumes a whole room. The flowers are borne in panicles; color lavender. The leaves are

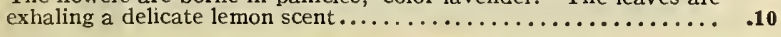

AMARYLLIS. It is one of the most exciting experiences to raise these gorgeous flowers from seed. All Amaryllis are raised from seed, and it is amongst these seedlings that are found the rare gems which are put out every season. Why not try it and perhaps you will strike the iucky seed. 5 seeds 10 cts.; 20 seeds, 35 cts.

\section{CALCEOLARIA}

(Hybrida grandiflora). A marvelously beautiful garden and pot plant The flowers are very large and in the shape of lady's slippers or pouches. The colors range from pure self yellow to orange and ruby color verging on maroon. The flowers are either self color or spotted, tigered, and mottled. All are exceedingly ornamental and beautiful. Calceolaria seed can be sown from June to September for winter flowering and early in the season for summer flowering. Treatment of seed same as other very fine seeds. Have your soil very finely pulverized and smoothed. Sow the seed carefully over surface and sift just a trifle of fine soil over this, jow the seed caref ully over surface and sift just a trifle of fine soil over this, watering use the very finest rose on watering pot. When young seedlings appear and are about 2 inches high, thin out and prick out the strongest, appear and are about 2 inches high, thin out and prick out the strongest,
transplanting these when 4 inches high. Calceolaria love warmth and sunshine.

Covent Garden Strain. The very choicest mixed, all colors. Per pkt. Trial pkt., 10 cts...\$0.25

Golden Glory (New Hardy Calceolaria). Pure yellow with spotted throat.......................... Trial pkt., 10 ets.. $\quad .25$

Alba (Novelty). In habit like Golden Glory but milk white spotted throat.......................... Trial pkt., 10 cts.. .25

Calceolaria Rugosa. Shrubby Calceolaria. Very beautiful for bedding and border. Form shrubs $\mathrm{I}^{1 / 2} \mathrm{2}$ to 2 feet high. The flowers are smaller than the bush form of Calceolaria and are borne in are smaller than the bush form of Calceolaria and are borne in
clusters. Very showy and ornamental. Choicest Hybrids mixed.............., ., Trial pkt., 10 ets. .25

\section{CYCLAMEN PERISICUM GIGANTEUM}

Universally admired for their rich coloring, beautiful foliage and profusion of bloom. The new strains are better than any ever produced through hybridization.

Giant Strain. Very large flowers borne on long stems, high above the mottled velvety leaves.

Pure White
Glowing Crimson
Salmon King

Blush Rose

Syringa Blue

Deep Rose

Trial pkt, 10 ets, large plkt, 50 Per pkt Mixed colors.......... Trial pkt., 10 cts.; large pkt., 50 cts... .25 Papilio Butterfly Cyclamen. Exquisitely frilled and frayed edges. Trial

Trial pkt., 10 ets.; large pkt., 50 cts... .25

Salmon Queen. A beautiful golden salmon color with frilled - petals. A beauty. Trial pkt., 10 cts.; large pkt., 50 cts... .25 CYPERUS ALTERNIFOLIUS. Known as umbrella plant. Very fine plant for veranda or house decoration. Well adapted for Aquariums, being semi-aquatic. When growing in pots, they need a saucer filled with water under the pots to thrive.

$$
\text { Trial pkt., 10cts:. }
$$

\section{COLEUS}

Ornamental foliage plants of the most varied colorings, resembling the rainbow in gorgeousness.

Finest Mixed Per pkt.

PARROT. One of the finest sorts ever introduced. The leaves of ten a foot long, are waved, spotted, striped, splashed, marbled with the choicest colors. Ht. Is in..........................

\section{BALSAM}

Balsams are increasing in popularity for the summer garden. The plants develop much larger flower sprays when set out two feet apart.
Splendid for table decoration. $1 \frac{1}{2} \mathrm{ft}$.

\section{PERFECTION BALSAM}

Blood Red. Per pkt.

Scarlet

$0 z ., .60 \quad \$ 0.10$

Violet Queen ..........

$1 / 4$ oz., .50 .10

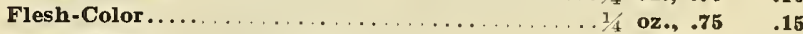

Pure white.........................1/4 oz., .75

Carnation striped varieties mixed............. $1 / 4$ oz., $.50 \quad .10$

Collection of 6 colors, separate, our selection

Mixed............................, \$1.00; 1/4 oz., .35 $\quad .10$

BARTONIA AUREA. A free blooming and showy plant, with large golden-yellow flowers; thrives well in partial shade. $1 \frac{1}{2} \mathrm{ft}$.. Pkt.。 


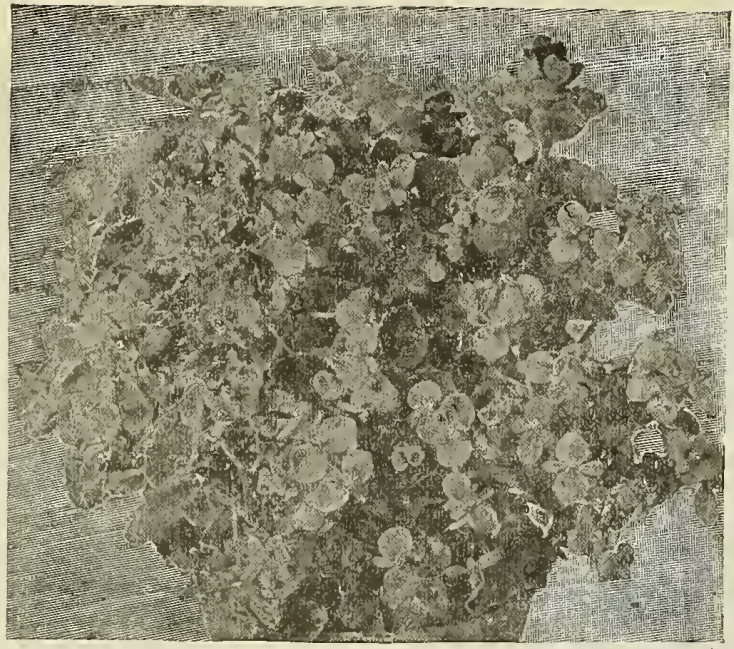

\section{BEGONIA SEMPERFLORENS $\begin{gathered}\text { Half Hardy } \\ \text { Annuals }\end{gathered}$}

Bedding varieties. More valuable than the much used and popular Geranium. More floriferous, more showy, more effective. 'The habit of these Begonias is more graceful and pleasing than any other richly flowering bedding plant. The plants grow to a height of 7 to 10 inches, are very compact, the fine waxy, bright green or, bronze foliage is smothered in a real avalanche of riotous brilliant bloom. These plants have another most desirable advantage. They succeed equally well in sunshine and in shade. Allow about 7 inches space for each plant.

\section{FIBROUS-ROOTED VARIETIES}

GRACILIS. This magnificent new Begonia is considered in Europe the finest variety for groups. Vigorous grower and in constant flower throughout the summer. For conservatory decoration it is equally valuable. $1 \mathrm{ft}$.

Deep scarlet, foliage crimson-bronze. Pkt., 10 cts.

Pink, 1347 Luminosa.

Scarlet. 1349 White.

\section{Pkt., 10 ets.}

Begonia Rex. One of the most beautiful foliage plants for the window garden and house.

Trial pkt., 10 ets.; pkt., 25 cts.

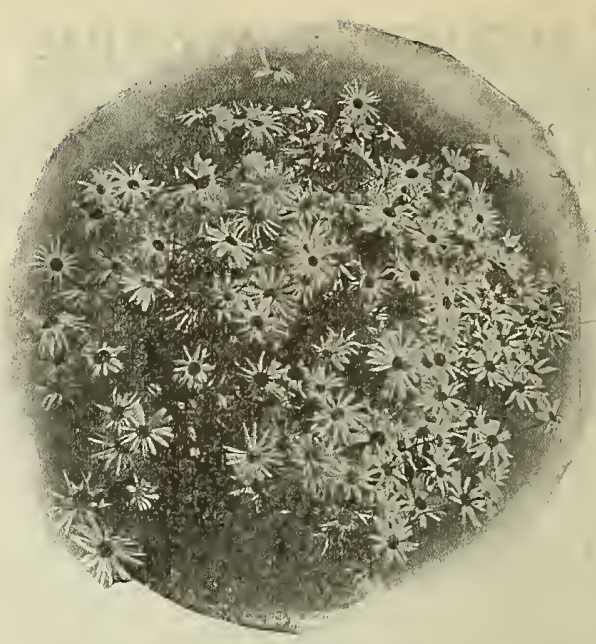

BRACHYCOME Half Hardy

Swan's River Daisy. Charming dwarf plant, 6 to 9 inches, fin pert. bedding, edging, and for rockwork..................... fo.

Little Blue Star. Flowers are a beautiful, brightest blue, covering almost to exclusion of foliage the compact little bushes. Each flower is perfect and starshaped........................ 10

Little White Star (Novelty). Pure wnite, very charming grown to-

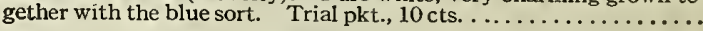

\section{BROWALLIA Half Hardy}

Speciosa Major. A very beautiful, profusely flowering sort with bright violet blue flowers of large size. Very useful for summer bedding. If sown in summer the plants will flower in the house during winter. Ht., $1 \frac{1}{2}$ feet. ....................1/4 oz., 35 cts... Elata cærulea grandiflora. Bright blue, very good for cutting. $1 / 4$ oz., 35 cts... .10 Elata alba. White variety................1/4 oz., 35 cts... 10 Mixed. All shades.....................1/4 oz., $30 \mathrm{cts...} \mathrm{.10}$

\section{CALENDULA (Pot Marigold)}

\section{CINERARIA HYBRIDA}

A highly ornamental and effective plant. Easy to grow and early to flower. Sow seed in early summer for winter flowering. (June is none too early.)

PrizelEshibition Strain. All colors from white to deep mar plt. pale rose to deep violet and purple. In separate colors, or mixed, Trial plst., 10 cts... $\$ 0.25$

Cineraria Stella (Novelty). Twisted and fluted petals like Cactus Dahlias. Flowers 2 to 3 inches diameter. Trial pkt., 10 cts.; .. 05

Cineraria Stellata (Star Cineraria). Grows in bush form, 24 inches high, the flowers are borne in large umbels the individual blossoms are star like, colors from white to rose, red and violet. Magnificent - -for?decorations.......................... Trial pkt., 10 ets... .25

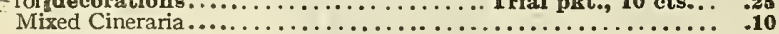

\section{CACCALIA (Tasselflower)}

From a strong central stem emerge lateral branches at the end of each appears an oblong leaf which encircles the stem. The flower appears at the terminais of the branches in clusters of three or more and resemble a PERFECT SILK TASSEL, hence its name.

Stems are strong, 18 to 20 inches long.

Very interesting and attractive.

Coccinea-Intense scarlet.

Aurea-Golden orange tint.

Per small pkt., 10 cts.; per large pkt., 25 cts.
Exceedingly attractive and showy, especially adapted for the wild garden. Blooming all summer, closing somewhat with approach of night, opening slightly on cloudy days, but flaunting its bright blossoms to the sunshine wide open. The plants reach a height of two feet and the color of flowers is very showy, not surpassed by anything in flower land.

Per pkt.

Lemon Queen. Clear lemon yellow.............., 25 cts...\$0.05 Meteor. Orange, striped primrose...................., 25 cts... 05 Pongeii. Double white........................., 30 cts... .05 Prince of Orange. Deep orange....................., 25 cts... .05 Prince of Orange. Deep orange $\ldots \ldots \ldots \ldots \ldots \ldots$. Oz., 25 cts... $\quad .05$

\section{CALLIOPSIS or COREOPSIS}

One of our very best hardy and satisfactory Annuals. Grows luxuriantly in any location, making a very showy effect and color spot in bed or border, supplying masses of most brilliant flowers for cutting and decorations. Water freely, especially when in bloom.

Bitor tia. Per pkt. 2 to 21 fet.

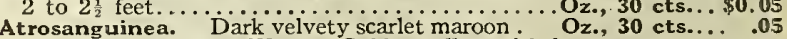
Drummondi Golden Wave. Golden yellow with brown centrs.

Radiata Tigerstar. A rich continuous blooming variety with very showy singular flowers. Each leaflet is twisted like those of a Cactus Dahlia. Towards the centre the flowers show a vivid red. dish brown, the other part being brilliant golden yellow, tigered like the Odontoglossum Orchids. Plants reach a height of 18 inches. forming round, compact bushes covered throughout summer with these gorgeous blossoms. Modest as to soil; very easy to grow.

these gorgeous blossoms. Modest as to soll, very easy to $1 / 4$ oz., $50 \mathrm{cts} . . .10$

\section{DWARF SORTS}

Tom Thumb Beauty. $8 \mathrm{in}$. high, flowers golden yellow with crimson centre, very compact. A gem for bed or border. $1 / 40$ oz., 30 cts. . .

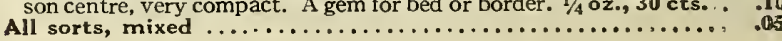
Oz., 30 cts.... .05 


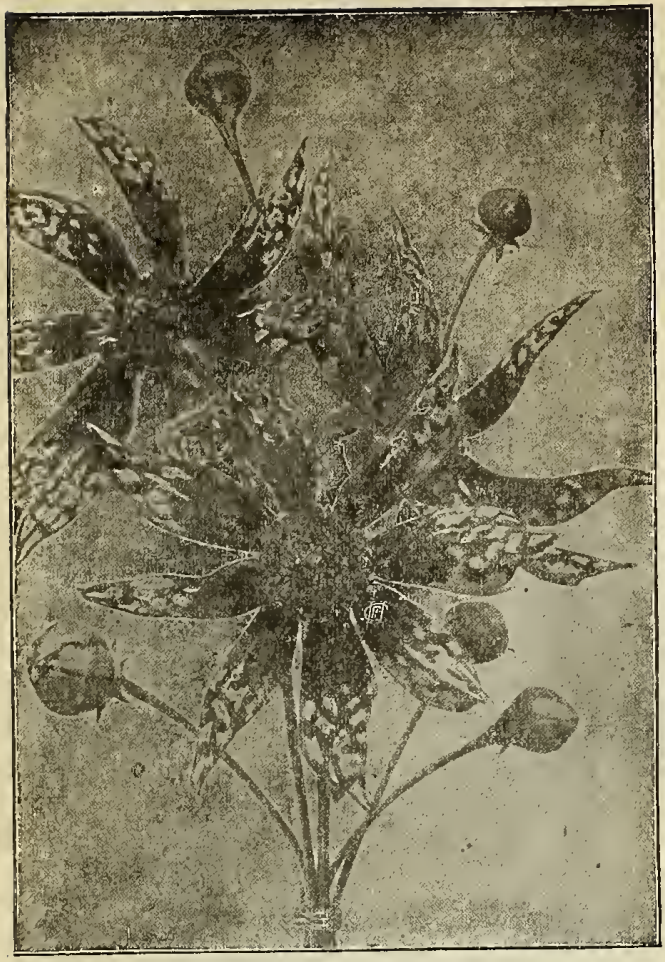

Calliopsis Tiger Star

\section{CANDYTUFT}

A most valuable annual bedding plant. Seeds can be sown at once where the plants are to flower. The flowers are similar to Sweet Alyssum, but much stronger and larger, the plants taller. All are sweet scented. Hyacinth flowered. Large pure white spiral spikes. Oz., 40 cts...\$0,10
. Empress. One foot. Pure white pyramidal....Oz., 50 cts. White Rocket. Large trusses................ 30 cts. Umbellata carnea. One foot. Flesh colored Oz., 40 cts. " carminea. One foot. Bright carmine Oz., $10 \mathrm{cts}$. Queen of Italy. Light lilac; very free flowering Rose Cardinal. Very rich striking color; quite

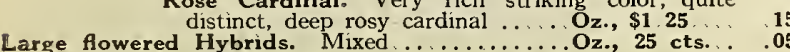

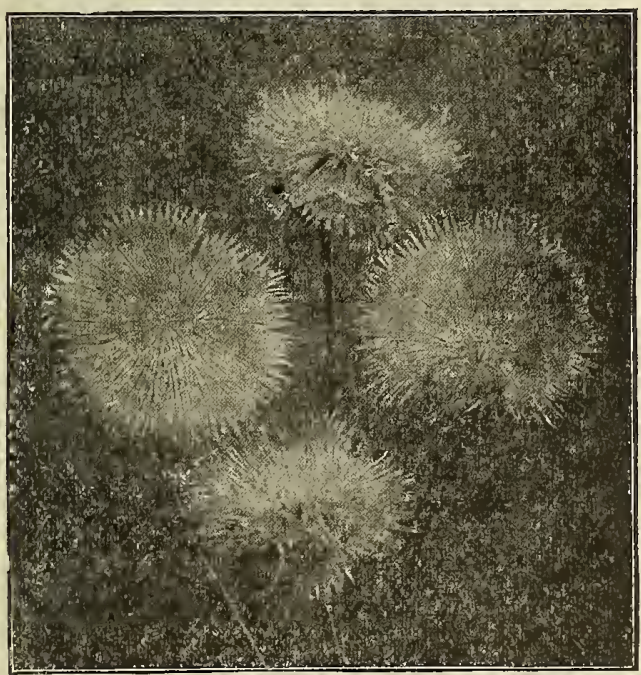

Centaurea Imperialis

Indispensable as cutting material. Elegant effects for decorations We furnish the following separate colors.

\section{CELOSIA Half Hardy}

COCKSCOMB

Celosia Cristata. Flowers pro duced in large cock's comblike heads of gorgeous colors. Highly ornamental for border and bedding, also beautiful for potplants. Delights in warm sunny positions.

Per pkt.

Glasgow Prize Crimson.\$0.10 Rose Empress, beautiful

$$
\text { rose tint }
$$

\section{OSTRICH PLUME COXCOMB}

For ornamental purposes this class is of the most striking beauty. The entire plant is covered with rich plumes of most brilliant colors. Very useful for borders.

Scarlet, 2 feet. Per pkt.

$1 / 4$ oz., 60 cţs. . $\$ 0.10$

Yow 1/4 oz., 60 cts... .10

Mixed. . 1/4 oz., 50 cts.. . .10

Pure White, Mauve, Pale Rose, Deep Rose, Dark Purple, Rose with $\begin{gathered}\text { Per } \\ \text { pkt. }\end{gathered}$ White Centre, White Shaded Rose. Separate colors, $1 / 4$ oz., 30 cts . . 10 Mixed, $1 / 4$ oz., 25 cts.

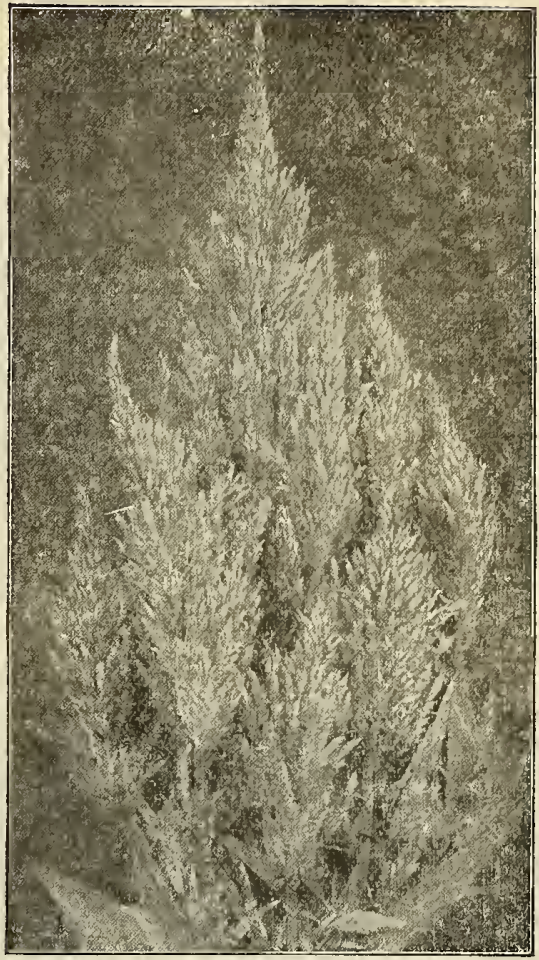

Celosia Ostrich Plume

\section{FRAGRANT CENTAUREAS Sultan)} Per pkt:

Margarita, pure white, very fragrant, 2 feet...... Oz., 50 cts... .10 Suaveolens, bright yellow....................... 50 cts... .1C Chameleon, soft yellow and rose................ 50 cts. ...10 All shades mixed......................., 40 cts... 10

\section{CENTAUREA, CORNFLOWER (Bachelor's}

One of the very hardiest easiest growing annuals. In fact they grow like weeds. In Europe where this flower grows wild it is found in great quantities amongst the cornfields, hence the name "Cornflower." They resow themselves year after year. Invaluable for the wild garder

Centaurea Cyanus Centaurea Cyanus
Emperor Wm, deep blue ........1/4 lb., $\$ 1.00 ;$ oz., 25 cts. $\$ 0.05$ Bright rose ...............1/4 lb., $\$ 1.00 ;$ oz., 25 cts. .05 Pure white ...............1/4 lb., \$1 00; oz., 25 cts... 05 All shades mixed. Single .......1/4 lb., \$1.00; oz., 25 cts. . .05 All shades mixed. Double .............1/4 oz., 35 cts... 10

\section{CENTAUREA}

\section{WHITE-LEAVED BEDDING VARIETIES. Dusty Miller}

These are grown especially for edging, or foliage beds. Height, 12 inches. The foliage is deeply cut or laciniated, of soft velvety texture, inches. The foliage is deeply cut or laciniated, of sof velvety texture, silvery white. Leaves thick, with the appearance of having been carved out of ivory, and in conjunction with lively colors such as Blue Lobelias, scarlet begonias, etc., make very effective displays. Start indoors or sow Per pkt.
in open after frost is over Gymnocarpa, narrow foliage ................... 35 cts... 10

\section{CHRYSANTHEMUMS}

Free-flowering hardy annuals blooming from July until frost, especially desirable for seashore and mountain gardens. $2 \mathrm{ft}$. 


\section{CHRYSANTHEMUMS}

SINGL.E VARIETIES.

Morning Star. Delicate primrose color. Pkt., 10 cts.; 1/4 oz., 25 cts.

Evening Star. Bright golden-yellow. Pkt., 10 cts.; $1 / 4$ oz., 20 ctss.

Northern Star. Large ivory-white flowers, with sulphur zone. zone. Pkt., 10 cts.; $1 / 4$ oz., 25cts.

Album. Large white flowers with purple eye and bright golden circle. Pkt., 10 cts.; 1/4 oz., 25 cts.

Atrococcineum. Deep scarlet. Pkt., 5 cts.; 1/4 0z., 25 cts.

Buridgianum. Lovely flowers, banded with crimson, white and. yellow. Rkt., 5 cts.; 1/4 oz., 25 cts.

Sing !e Mixed. Pist., 5 cts.; oz., 30 cts.

DOUBLE VARIETIES. 3 feet.

Crimson.

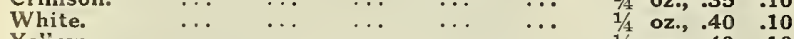
$\begin{array}{lllllllll}\text { Yellow. } & \ldots & \ldots & \ldots & \ldots & \ldots & 1 / 4 \text { oz., } .40 & .10\end{array}$ Mixed. $\quad \ldots . \quad \ldots \quad \ldots \quad \ldots .0 z ., 1.00$; 1/1 0z., $.35 \quad .10$ CHRYSANTHEMUM.

Inodorum Bridal Robe. A compact plant. with double flowers of purest white, carried well above the dark green, finely cut foliage The cut flowers are admirably adapted for all kinds of floral work, $1 \mathrm{ft}$. Pkt., $10 \mathrm{cts}$; $1 / 8$ oz, 50 cts.

Special Mixture. Dothle and single; all the most beautiful varieties, Pkt., 10 cts.; $1 / 1$ oz., 25 cts.; oz., 75 cts.

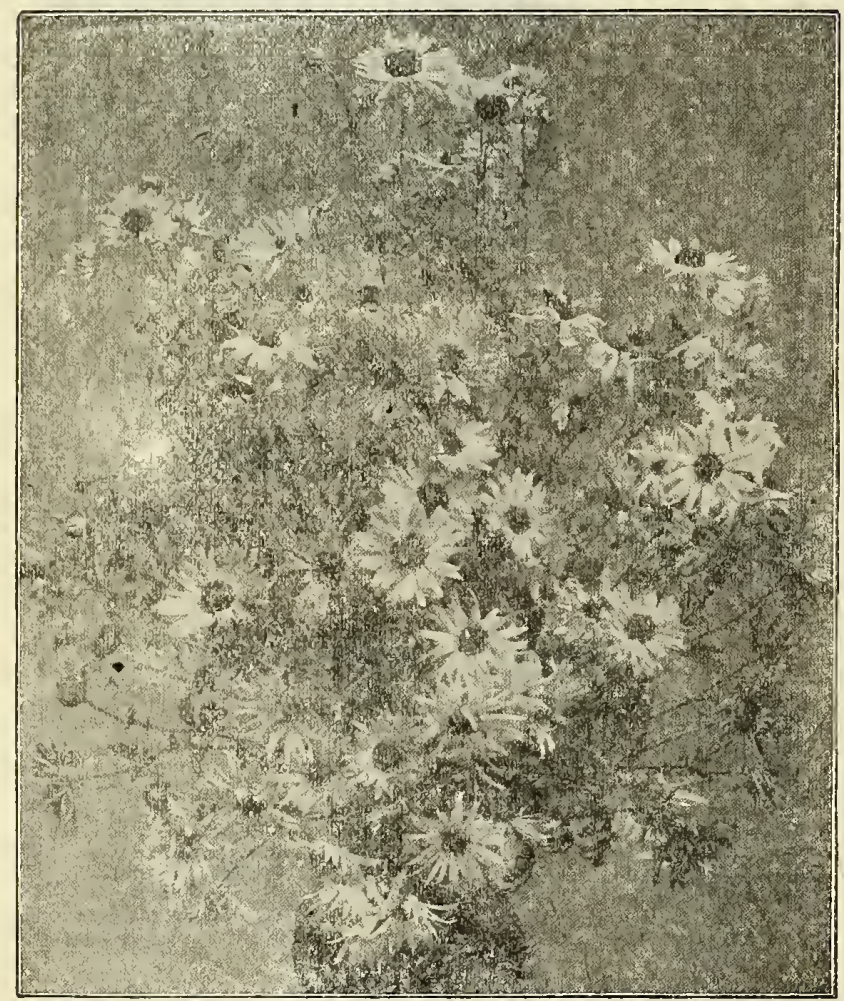

\section{GRAND NOVELTY SINGLE FLOWERING CHRYSANTHEMUMS}

This is the grandest new race of Hybrids. Seed sown in February and March in the house, the young plants transplanted as soon as weather permits will flower early July. Their varied colors, abundant and profuse flowering until heavy frosts cut them down, will make these plants a necessity for every garden, large or small. Sown in the open ground as soon as frosts are out of the soil, they will flower by middle to end of August. For a gorgeous, royal display of colors and beauty nothing excells the single Hybrid Chrysanthemums. They require very little care planted in good soil and given water and sunshine. We have received delighted letters from our customers who planted the seed last season.

One lady writes from Seattle, Wash.: "The single Chrysanthemums, seed of which I purchased from you in March, are in full bloom, and such a display of beauty I have rarely seen."

Per pkt.
Per pkt. formed flowers of bright golden tint......1/8 oz., 40 cts...\$0.10

Primrose Queen. Dwarf and compact. Fine double, of good form and clear primrose color ...........1/8 oz., 40 cts... .10 Mixed. Double annual Chrysanthemums

Oz., 75 cts.; $1 / 4$ oz., 25 cts... . .10

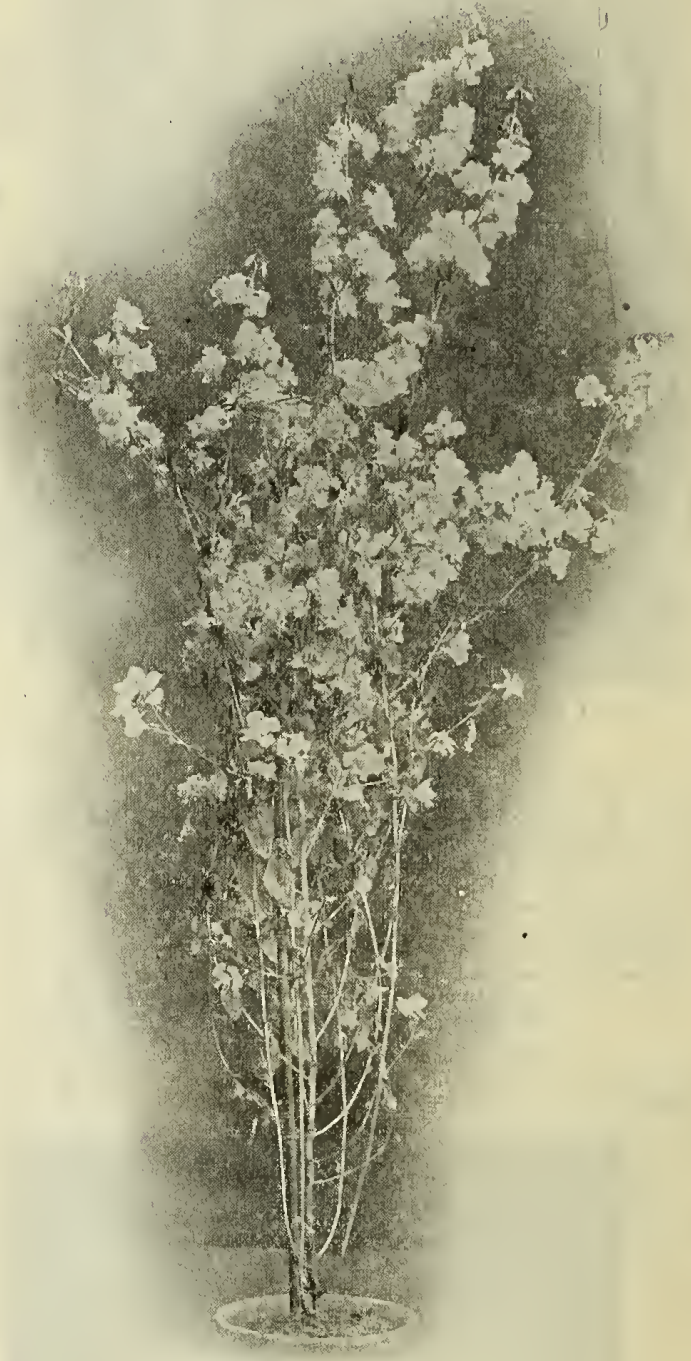

CLARKIA

This superb hardy annual should be grown anywhere where the most exquisite flowers are wanted. Not sufficiently known in this country. it forms in Europe, especially in England, one of the most popular garden annuals. The foliage is a very bright green, the stems are slender and need a support or staking when growing up. The flowers are rosette-like resembling Ranunculus and of the richest tints. Like stocks single, semisemble, and double. Ht., 18 to 20 inches. Very beautiful for table
double decorations.

Clarkia Brilliant. Very bright orange, very double. $\begin{array}{r}\text { Per pkt. } \\ \text { 1/8 oz., } 25 \text { cts...\$0.05 }\end{array}$

Carmine Queen, Light rose carmine $\ldots .1 / 8$ oz., 25 cts... . 05

Chamois Queen. Delicate pale chamois .....1/8 oz., 25 cts... .05

Alba. Pure white, very double............1/8 oz., 25 cts... 05

Purple Prince. Brilliant light purple.......1/8 oz., 25 cts... . 05

Vesuvius. Intense orange scarlet. . .........1/8 oz., 25 cts... 05 Mixed. ........................1/8 oz., 25 cts.., .05 


\section{COSMOS}

The hardiness and easy cultivation of the Cosmos is known to every Flower Lover. The seed germinates rapidly and the young plants attain their flowering maturity in a short time. For decorative effect in the garden, and for cutting few flowers equal the Cosmos.

New Giant Hybrids. The individual flowers grow to an enormous size, measuring 4 to 5 inches in diameter, bloom in greatest profize, measuring 4 to 5 inches in diameter, bloom in greatest prosheltered positions the blooms continue up down the bushes. In tints are the most brilliant, running the whole scale of color from Pkt. pure white through all shades of blush, light rose. deep rose to glowing red. Trial pkt., 10 cts.; pkt., \$0.25

Early Flowering. These, if sown out-of-doors in May, will flower end of July. They grow 4 feet high and over, do not require staking like the late flowering sorts. Flowers are large and when cut last for a couple of weeks in water. White and rose, either

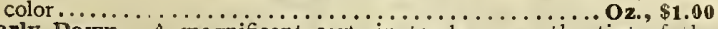
Early Dawn. A magnificent sort, in tender rose, the tint of the sky before the sun appears. Delicate, yet brilliant. $1 / 4$ oz., 30 cts. .10 Lady Lenox. A magnifent, large, brillant rose sort. $1 / 4$ oz., 50 cts. 15 do not appear until Oct do not appear until October when most other flowers have gone to their rest. Mammoth White, Mammoth Rose, Mammoth Crimson. All colors mixed....................., \$1.00 .10 Mixed.............................., Oz., \$1.00 .10

\section{DIMORPHOTHECA AURANTIACA}

(The Orange Daisy.) One of the most beautiful and satisfactory introductions from South Africa. It is an annual of easiest culture, needing ittle care, thriving on any good soil. The flowers, which cover the com. pact bushes in greatest profusion all through summer till late fall, are fully 3 inches in diameter, of rich satin texture and a glorious orange color. Grand for groups and borders. Sow the seed thickly in a warm, sunny spot, thin out to $\mathrm{I}$ foot apart, or sow in drills $\mathrm{I} 5$ inches apart. A bed of them presents a magnificent color picture. Height, is inches.

Pkt., 10 cts.; large pkt., 25 ets.; $1-16$ oz., 50 ets.

\section{DIANTHUS, or PINK}

Most brilliant effects may be obtained by using Dianthus in the borders. They grow freely from seed and come true to color. Sow outdoors when langer of frost is past. The perennials will bloom the first year if the seed is sown early. Also useful for pot culture. Pkt. Chinensis (Chinese Pink). Double mixed colors.......\$0.05 Single, Finest Mixed ............................. TEDDEWIGII, Single Varieties-

Oz.

Crimson Belle. Brilliant crimson. $1 / 4$ oz., 50c...... .10 Salmon Queen, Single. Delicate Salmon-red.

1/2 oz., 50c... .10 The Bride. Very dwarf and compact; pure white

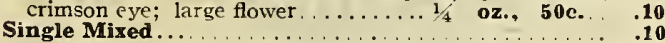
75

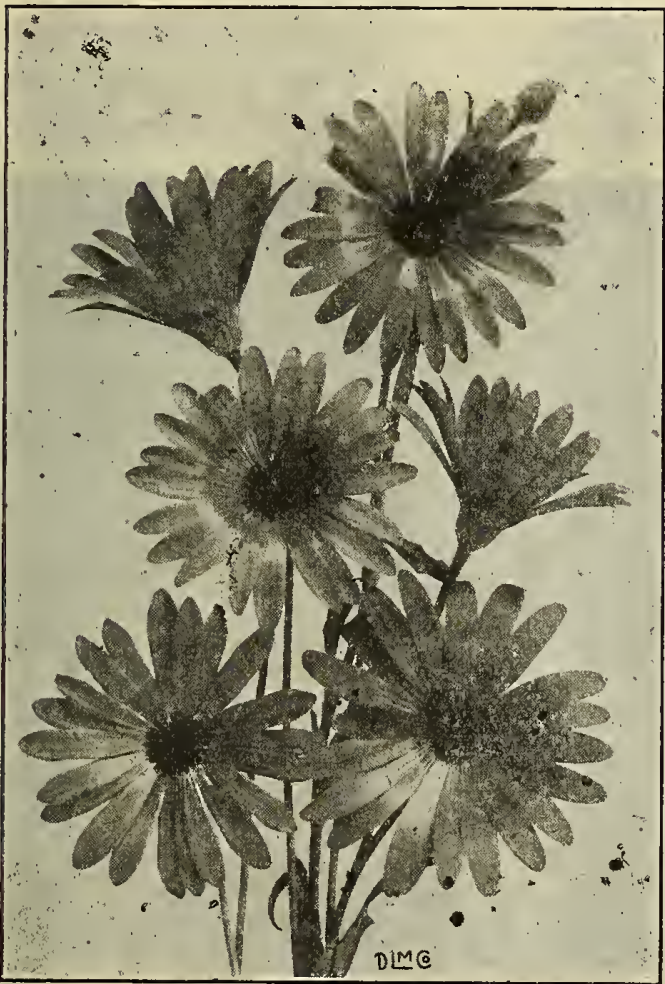

Dimorphotheca

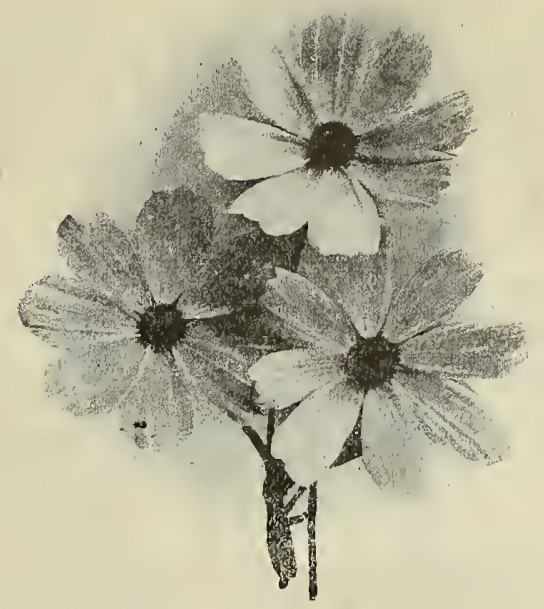

Cosmos

HEDDEWIGIT, Double Varieties-

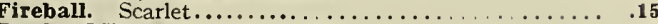

Snowdrift, Double. A grand new double white summer pink; large flowers. One of the best introductions of the season.

Vesurius, Single. A beautiful single variety, with intense orange-scarlet flowers, a most brilliant color and a grand acquisition to this class of plants. . acquision to thi lass of plant................ 02., 50c. DIADEMATUS fl. pl. (Diadem Pink). Very unusual, attractive coloring, including pink, rose, crimson and purple grounds coloring, including pink, rose, crimson and purple grounds
and all having a pretty lace-like edging of white; double. and all having a pretty lace-like edging of white; double.

\section{SPECIAL}

DIANTHUS or RAINBOW PINK. Quick flowering, unsurpassed Pk t.

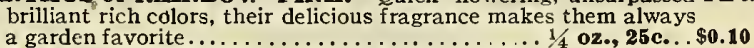
OX.E YE MARGUERITEs. Always showy and effective. Splendid to grow for cut flowers. They make a lovely combination with

"Batchelor Buttons or Centaurea." $\ldots \ldots \ldots \ldots \ldots \ldots \ldots$. $\ldots$ oz., 25e. .10 flowers, perfect form and exceedingly free flowering.

2 pkts., $25 \mathrm{c}$.

\section{HARDY GARDEN PINKS}

PLUMarius (Pheasant's Eye, or Grass Pink). Fringed, single

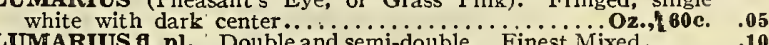

All sorts of Dianthus, Mixed...... 10 ACINT ATUS Mirabilis, Japanese Hybrids. The from I2 to Is inches in height and produce their large. lovely from I2 to Is inches in height and produce their large. lovely The petals of 3 to 4 inches in diameter, on stiff, upright stems. The petals of the flowers are very deeply cut into fine strips of There are all shades of color, from pure white and white with pink or red zones to rose and deep purplish red. Blooms all Summer............................1/8 oz., 35c.

\section{ESCHSCHOLTZIA}

(California Poppy). One of the most popular and widely known garden annuals. Has large poppy-like flowers of the widest range of brilliant colors. Stands considerable cold and still blooms after first frosts. If well protected plants will live through the winter.

Pkt. California. Bright golden yellow.............., 30 cts.\$0.05 Alba. Pure white......................., 30 cts. .05 Carmine King. Beautiful rose carmine..............., 60 cts. 15 Golden West (Maritima). Orange yellow................. 30 cts. .05 Mandarin. Bright scarlet and gold .................... 30 cts. $\quad .05$ Mikado. New lustrous orange crimson. giant bloom........... 50 cts. $\quad .15$ Mainado. New lustrous orange crimson, giant bloom..... Oz., 50 cts. Dainty Queen. Delicate blush or pale coral rose deepening toward
the edges with a ground work of pale cream color the same inside and outside of petals. An enchanting, beautiful blossom.

Oz., \$1.00.. .10

All shades of Eschscholtzia, mired.......... Oz., 30 cts... .05

\section{ERYSIMUM ARKANSANUM}

Flowers from June till frost. Grows 24 to 30 inches high, branches upright from a single stem, each shoot bearing a mass of starry lemon or orange yellow flowers. Trial pkt., 10 cts.; large pkt., 25 cts.

CERASTIUM Tomentosum. (Snow in Summer). H. P. Beautiful foliage, silver white with masses of snowy flowers. A gem for edging rockwork, etc., Io to 12 inches. Pkt., 10 cts. 


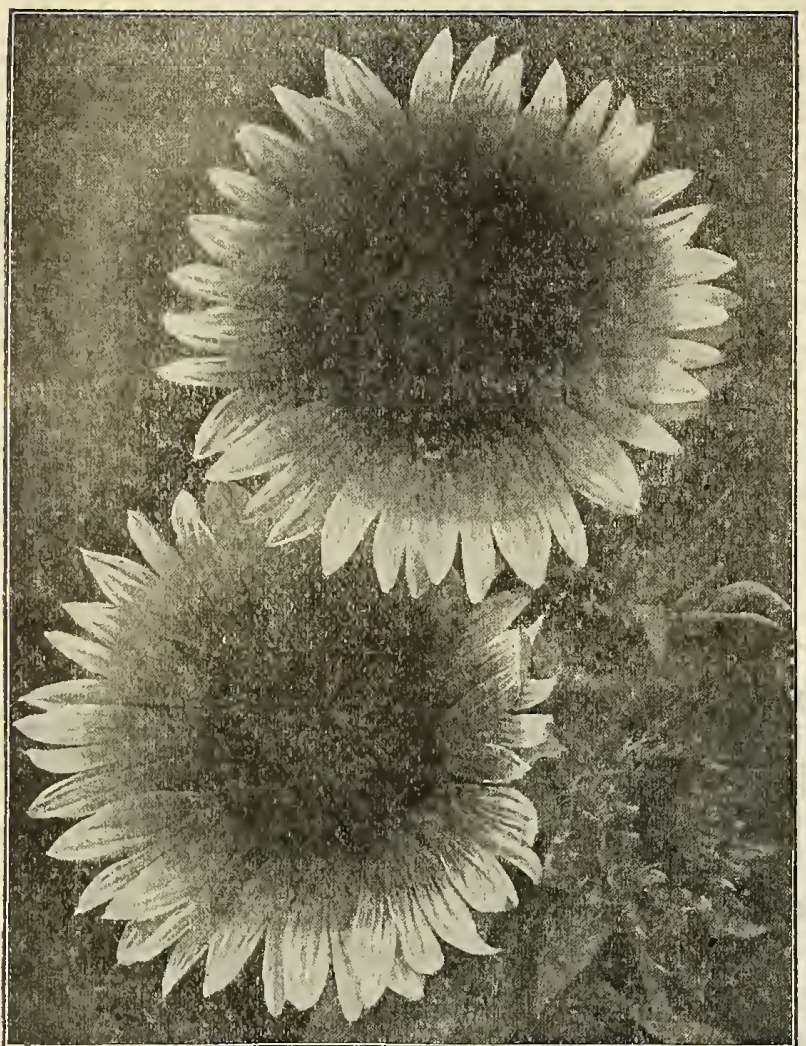

Gaillardia Sybilla

\section{GAILLARDIA Half Hardy}

BLANKETFLOWER

Seeds sown in May will flower late July and continue until frosts. Plants grow 18 to 20 inches high and produce an abundance of flowers especially valuable for cutting. The various color effects are all flame-like and very showy, including every rich shade of crimson and bright golden yellow.

$$
\text { ANNUAL SORTS }
$$

The Bride. A new and still rare sort. The flowers are cream white
very double, borne on extra long stems making it especially valuable

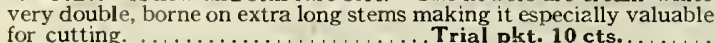

Amblyodon sanguinea. Richest blood-red very striking. 1 foot. Oz., 40 cts.

Lorenziana. Large, handsome flowers, quilled petals; in rich shades of red and yellow. 2 feet ............ Oz., 50 cts.

Sulphurea. Pale yellow ..........., 50 cts.

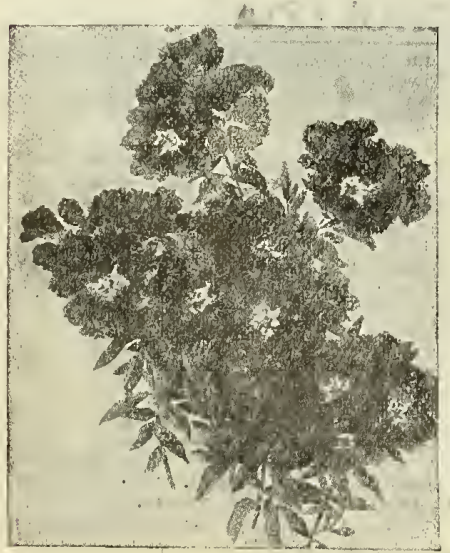

Godetia Crimson Glow
Exceedingly graceful early fiowering plants for border and for cutting. Produces a mass of bloom long before other annuals are out of the ground. Very valuable for bees. Ht. 10 inches, Charming colors, lilac, to red and

Mixed..Oz., 25 cts... . .05

"Our purpose is to man age our business with such care that our establishment will become known wherever this Catalogue reaches, a one of high integrity, where you may send with utmost reliance for anything needed in our line, with the assurance that you will be served with painstaking care and that every dollar spent wil bring you full value in return.

\section{GAILLARDIA GRANDIFLORA SYBILLA}

\section{Per pkt.}

This splendid, larire flowcritig species has been created after years of careful luybridizing of several sorts. The flowers are a bright carmine red, germinating into white to light yellow points, contrasting beautifully with the dark center. Nothing can look more rich and dazzling in effect than a group of these plants when in flower. Splendid for herbaceots border or as a single plant. Wherever seen it attracts ádmiration. Grows and does well anywhere. The flowers if cut last for weeks. The colors under artificial light are marvelously effective ................... 10 Choice Mixed annual sorts .......................... 40 cts.. 10

\section{GODETIAS}

Magnificent hardy annuals which compete with the Clarkias for beauty and usefulness. Easily grown, satisfied with any fairly good soil, they flower with striking effect. The immense quantity of bloom produced is almost incredible. Every twig is smothered with flowers of most brilliant hue.

Crimson Glow. Ht. 10 inches. Forms a compact little bush smothered with flowers of the most dazzling intense crimson. A

bed of this sort produces an effect so vivid and intense, that it is

impossible to describe it ................1/8 oz., 20 cts. .\$0, 10

Duchess of Albany. Large, pure white, same habit as the Crimson

Glow ......................... oz., 25 cts... 10

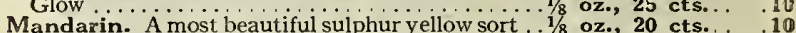

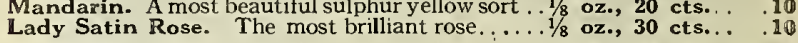

All shades mixed...................1/4 oz., 25 cts. . . 0.5

Do not fail to grow a bed of Godetias. It will surprise and delight you. Also extremely beautiful for windowboxes and pot plants. Thousands are sold in European markets grown in pots.

\section{GYPSOPHYLLA}

For border decorations and for cutting this hardy annual is simply priceless. Exquisitely graceful and feathery in appearance, it is most useful in -combination with other heavier flowers, and forms the most delightful addition to decorations, bouquets, etc. Sow it in open ground amongst petunias. The effect is charming.

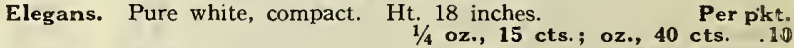

Elegans, Rosea. Pink ................. Oz., 25 cts... .05

Muralis. Deep rose; exceedingly fine for rockwork. Ht. 9 inches. . . id

Elegans, mixed shades.........1/4 oz., 15 cts.; oz., 40 cts... . .

\section{HELIANTHUS}

\section{SUNFLOWERS}

Plants of majestic growth and immense showy flowers. Most suitable for shrubberies, as screens for fences or unsightly walls, for wild gardens, and subtropical planting.

Argophyllus. Exquisite silvery foliage, fiowers medium sized, golden yellow with dark centre. A grand plant for the shrubbery, mixed border, and wild garden. Ht. 5 feet..... Oz, 25 cts.?

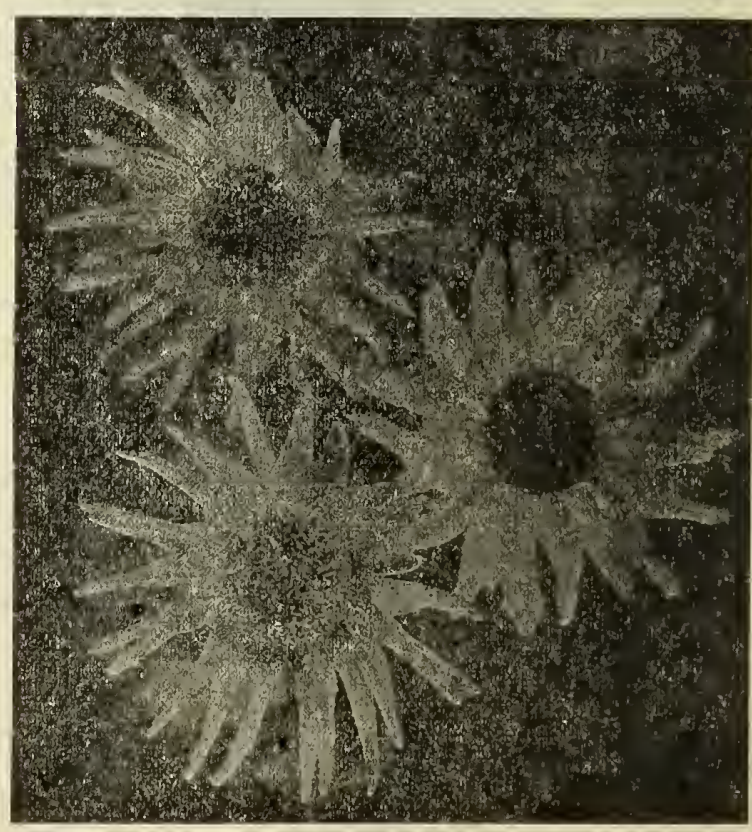

Sunflower-Starlight 
Golden Nigger. Early blooming sort, of branching habit, deep green foliage, dark stems, and an abundance of golden yellow flowers almost black centre. Ht. 6 feet.................... 30 cts... California Sunflower. Large, deep yellow flowers of perfect

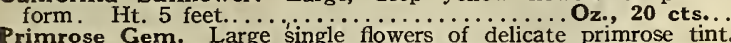
Ht. 6 feet. One of the most beautiful sorts ..... Oz., 30 cts. Giant Russian. Ht. 8 to 10 feet. Very large, single, yellow flowers ....................... : Oz.. 10 cts.: $1 / 4$ lb., 25 cts... Annual single Sunflower, mixed. Tall sorts. Oz., 25 cts..... Annual single Sunfower, mixed. Tall sorts. Oz., $25 \mathrm{cts} . .$. Sunflower Starlight. The flowers are large, of the most graceful appearance, with beautiful twisted petals like the finest form of appearance, with beautiful twisted petals like the finest form of Cactus Dahlia. Color is a bright canary yellow; the single packet, 10 cts..........................1/4 oz., 75 cts..

\section{DWARF OR MINIATURE ANNUAL SUNFLOWERS}

Cucumerifolius. Ht. 3 feet to 4 feet. Single flowers of golden yellow with black centre, produced in enormous quantities on branching stems. Blooms during July till frost cuts it down. Very ornamental. .......................... Golden Star. Starshaped double form of Miniature Sunflowers, petals twisted like a Cactus Dahlia. One of the finest, newest sorts. Ht. 3 ffeet. $\mathrm{i} \ldots \ldots \ldots \ldots \ldots$. $\ldots \ldots \ldots 1 / 2$ oz., 40 cts...

Perkeo, a charming Miniature sort. Ht. 1 foot. Forms compact bushes one foot and more in diameter, covered through summer till frosts with a profusion of bright yellow flowers. Black cen-

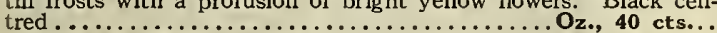

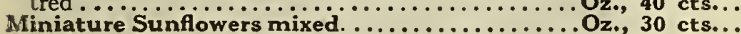

\section{GLAUCIUM \\ (HORNED POPPY)}

Grows in the poorest and sandiest soil. The foliage is bluish gray and highly ornamental. Flowers are large, deep orange scarlet with large black spots at the base of petals, and very showy. Ht., 18 inches. Sow in heat in spring and plant out when weather is warm.

\section{HIBISCUS}

$1 / 4$ oz., 35 cts..

\section{MARSHMALLOW}

Africanus. Rich yellow flowers with deep purple centres. Ht 2 feet ................................ 25 cts..

\section{ICEPLANT Half Hardy MESEMBRYANTHEMUM}

Very exquisite foliage, thick and succulent, covered with ice-like or crystal-like transparent globules, making them appear as if frosted over with diamants. Especially adapted for dry, sunny spots. Invaluable for rockwork, borders, etc.

Chrystallinum. White flowered. Ht. 10 inches.................

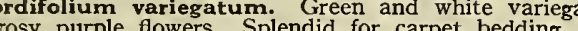
Splendid for carpet bedding. Trial pkt

\section{INOPSIDIUM}

\section{DIAMOND FLOWER}

A delightful and lovely flower. You can see it grow. A pleasure for children to grow as a potplant or in their little gardens, as the seed starts in a few days and the delicate pale lilac or blue flowers appear in a short time, fairly smothering the dense green foliage. Lovely for carpeting under bulbs or other plants. Does best in partial shade. Loves moisture. Ht. 2 to 3 inches. A very pretty plant for pots ..........................1/8 oz., 30 cts...

\section{KOCHIA TRICHOPHYLLA SUMMER CYPRESS (BURNING BUSH)}

Beautiful, showy Annual, 3 feet. Sow thinly in spring, plants soon form fine pyramidal specimens or if sown in rows form a hedge of perfect symmetry in late summer; when the weather turns cold the whole plant turns a fiery red. A splendid plant to divide flower and kitchen gardens or wherever a low hedge and quick growth is desired. .............................

\section{LAVATERA}

\section{ANNUAL MALLOW}

This is one of the very best and most valuable plants for relieving the flatness of a bed or border. It shoots up a graceful stem like a willow the the flowers stand out like bells on wiry stems. the flowers stand out like bells on wiry stems. Ht. 3 feet. The flowers in very useful for table decorations, where the beautifui deep green foliage geeds where the plant is to flower, as it will not stand transplanting. The Iavateras bloom from July to late September.

Splendens white..............1/4 oz., 25 cts. oz., 75 cts... 10 Splendens rosea. ..........1/4 oz., 25 cts.; oz., 75 cts.

Sunset (New.) Habit of plant compact, the large flowers are of the most brilliant satiny rose. Trial pkt, $10 \mathrm{cts}$
.05

.05

.05

.05

.05

20

10

05

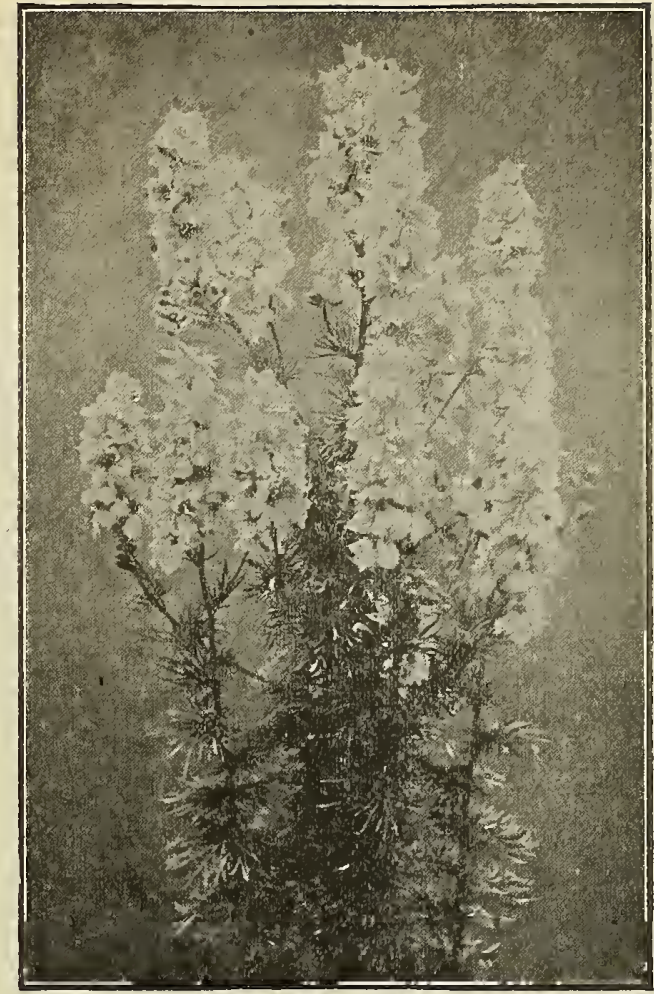

Larkspur Emperor

\section{LYCHNIS COELI ROSA}

Coelirosa fimbriata flowers light rose, shaded white toward Per Plst. centre; the petals are prettily fringed. Very light, graceful, bushy habit. Ht. 10 inches .

\section{LARKSPUR \\ DELPHINIUMS \\ Larkspur lifting turquoise spires Bluer than the sorcerer's fires.}

Magnificent hardy annuals growing 2 to 3 feet tall, with immense spikes of richly colored flowers. The foliage is finely cut, fernlike. Very valuable for summer bedding. Excellent for cutting. Sow seeds as early in spring as possible in the place where they are to flower. They early in spring as possible in the place where they are to flower. They of each plant lasts only about a month sowings should be made at intervals of each plant lasts only about a

Prize strain of Stock Flowered Larkspur in separate colors, white, rose, flesh colored, deep rose, steel blue, dark blue, three colored....................... Novelty of Stock-flowered Larkspur "Rosy Scarlet"

Larkspur Emperor. Mixed. Long, very showy spikes cts... $1 / 2$ oz., 20 cts.

Blue Butterfly. New annual Delphinium. An exquisite Salvia blue. Dwarf sort 12 to 15 inches bigh forming a free flowering bush. Most attractive for bedding or as a potplant. . $1 / 4 \mathrm{oz}$., $35 \mathrm{cts}$.

\section{LOBELIA}

Is profusely used for bedding, carpet effects, vases, window boxes. hanging baskets. Wherever used it is distinctive, gracious, and charming. To secure early bloom for the garden, where no greenhouse room is available, the seeds should be started early either in house or hotbed, We distinguish two types of this charming flower, the bushform and the trailing.

\section{BUSHFORM LOBELIAS}

Crystal Palace Compacta. Coimpact growth. Ht. 1/2 foot. Flowers an intense blue, foliage bronze colored $\ldots .1 / 4$ oz., 75 cts...

Emperor William. A very fine light shade of blue, foliage bright green. Ht. 6 inches. ......................1/4, oz., 60 cts... 


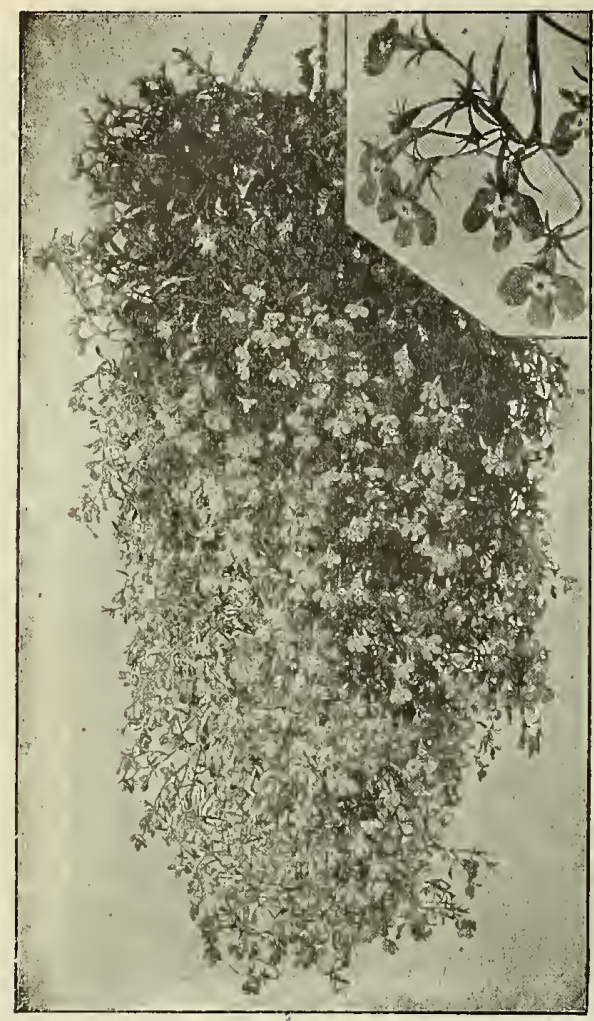

Lobelia Sapphire

\section{LINARIA}

Compacta Golden Queen. A golden foliaged sort, the flowers are a deep dark blue: Very showy. $1 / 8$ oz., 50 cts. ; pkt., 10 cts.

Snowbird. Pure white, large flowers, green foliage. 1/4 oz., 75 cts.; pkt., $10 \mathrm{cts}$

Kermesina occulata. An exquisite sort. The large flowers are a beautiful red shade with white eye. 1/8 oz., 60 cts. ;

\section{TRAILING LOBELIA}

Trailing Lobelias are in great demand for decoration of window boxes, balconies, verandas, hanging baskets. The new Lobelia which is named "Sapphire" on account of its wonderful brilliant blue shade, the color of that prccious stone, is a gem for any named purpose. The flowers.are unusually large, with a large white eye, making it most effective The blossoms are thickly set on the long graceful sprays of foliage which frequently at tain a length of $t$ wo feet. A plant of this new Lofeet. A plant of this new LObelue covered with its bright
blue is a splendid sight. attracting every eye.

By sowing in the house in January-February, the plant will bloom end of May, continuing till late fall. If sown in September extra strong plants will commence flowering in April

Lobelia Hybrida Sapphire. Trial pkts., 10 cts.; pkt. 25 .cts.

Hamburgia. Bright sky blue with pure white eye. Its chief merit lies in its phenomenal rapid growth, throwing out shoots 12 to 15 inches long in incredibly short time, covereo with flowers, the branches with flowers, the branches
hanging gracefully over pots or baskets. Pkt., 10 cts.

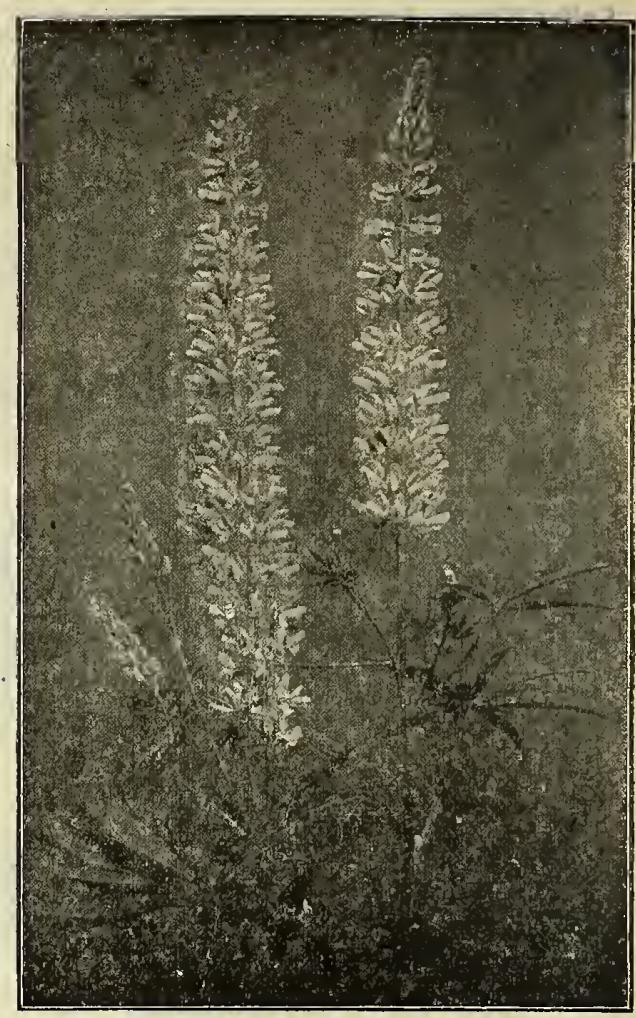

\section{LUPINUS}

\section{TOADFLAX}

Beautiful, very free flowering, hardy annuals which thrive best in open sunny situations. Flowers resemble in shape the Snapdragons.

White Pearl. Beautiful large white flowers with golden blotch at pkt. mouth

2ueen of Roses, rich rosy carmine. Ht. 1 foot.............. 10

Maroccana. "Excelsior." Flowers running in all shades from light blue to dark violet, pink, crimson and yellow, all with a

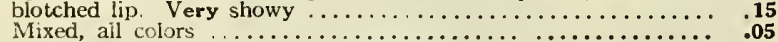

\section{LINUM}

\section{FLAX}

Giandiflorum Blue. Charming azure blue flowers. Ht. 1 foot. Splendid bedder. Very graceful. oz., 30 cts.

Grandiforum Coccineum. A marvelously brilliant colored summer annual. Flowers are a glowing crimson rose and by making successive sowings can be had in bloom from May till October. Ht. 1 foot. ............................ oz., 30 cts... . 05

\section{MARIGOLD Half Hardy $_{\text {Annual }}$ \\ TAGETES}

Midsummer-flowering, showy, decorative plants, which are at their best when the early summer bloom is drawing to its close. They have one great advantage, that they thrive almost anywhere where flowers can be grown at all and need a minimum of care. Anybody succeeds with these plants. They are one of the joys of the amateur.

\section{TALL MARIGOLDS}

Tall African. Double Lemon ....1/4 oz., 25 cts.; oz., 75 cts... Per 10 Tall African. Double Orange. ...11/4 oz., 25 cts.; oz., 75 cts... 10 Tall Mixed....................1/4 oz., 20 cts.; oz., 65 cts... 10

\section{DWARF FRENCH MARIGOLDS}

These grow only 12 to 15 inches in height. The flowers are rather flat with a satiny or velvety sheen. They are exceedingly fine as a bedding or border plant.

Legion d'Honneur. Single, specially selected strain, flowers bright yellow, with clear, vivid, dark red or crimson velvety blotches. A very unique bedder. Ht. 9 inches. $1 / 4$ oz., 15 cts... French d warf gold striped, double. Ht. 12 in. $1 / 4$ oz., 15 cts... Extra dwarf gold striped. Ht. 12 inches. $1 / 4$ oz., 15 cts.

Dwarf Marigolds mixed ...................... 1/4 oz., 15 cts..
These must be reckoned amongst the most useful as well as beautiful of our Garden Annuals. Of astonishingly rapid growth, the flowers appear six to seven weeks after the seed is sown, and are best sown where they are intended to bloom, as they bear transplanting poorly. A dry, very sunny exposure suits them best. Where continued bloom is wanted sow seed at intervals. Annual Lupins will flower about one month and then begin to form seed pods. Especially fine in borders and grand for cutting. Hartwegi Albus. Pure white. Ht. 2 feet.

Coelestinus. Bright blue. Ht. 2 feet.

Roseus. Ht. "2 feet.

Sulphureum or Primrose. Ht. 2 feet. Sulphureum Superbus, rosy purple and white, very showy. Ht. 2 feet. Any of these colors ..........1/2 oz., 15 cts.,; oz., 30 cts... .05 Mixed colors ........... 1/2 oz., 15 cts.; oz., 25 cts.,........ .05 Mixed annual sorts for wild gardens.

oz., 25 cts., $1 / 4$ lb., $\$ 1.00$; per lb., $\$ 4.00 \ldots$. .05

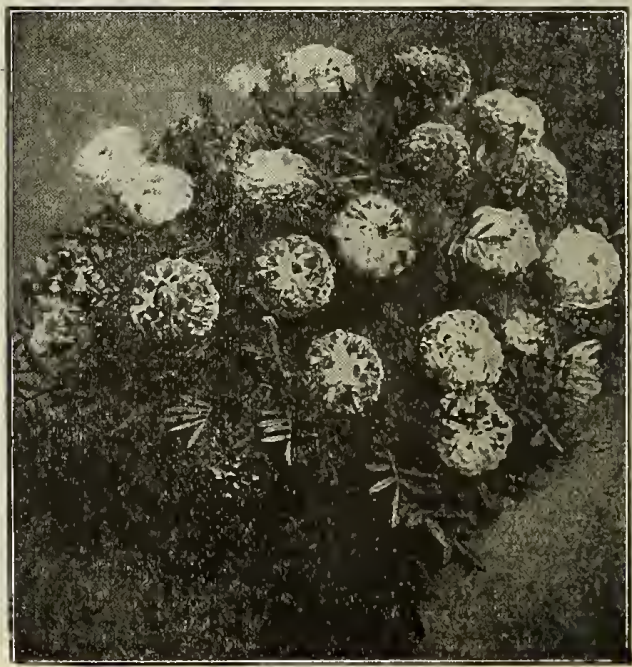

Dwarf French Marigold 


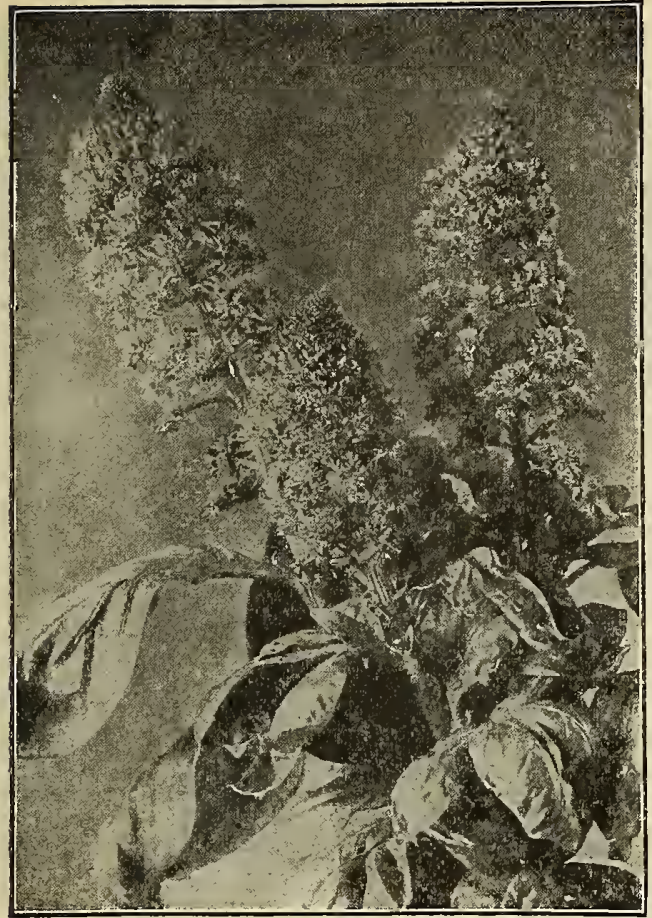

Mignonette

\section{MIGNONETTE}

Is there any flower lover who does not know this essentially weet blossom? While not remarkable for beauty the heavenly fragrance the tiny blossoms emit has endeared it to every one. They are fine as pot plants, and thrive in almost any good garden soil. Sow seeds out of doors where you wish the plants to bloom. Look out for green worms on Resedas, Spray with insecticide preferably Aphine. The worms can be caught by hand early mornings. Laying fresh cabbage leaves amongst the plants will do away with many of them, as they will leave the Mignonette to feed on cabbage.

Per pkt.

Bismark. Heavy spikes of deliciously scented flowers. One of the best. Very suitable for pot culture. $1 / 4 \mathbf{~ o z . ,} 30 \mathrm{cts} . . \$ 0.10$

Goliath. This variety is claimed by many as being the sort par excellence. Plants are of compact habit, rich green foliage, the gigantic trusses of flowers borne on erect strong stems, surpassing all others in brilliancy of coloring, which is a clear red.......................1/4 oz., 30 cts...

Mammoth Fragrant. A strain unsurpassed for cutting, either in the greenhouse or out-of-doors. Mammoth spikes either in the greenhouse or out-of-doors. Mammoth spikes
of the most fragrant flowers, borne on plants remarkable for their robust and vigorous growth. 2 feet $1 / 4$ oz., 50 cts.; trial pkt., 25 cts... . 15 White Pearl. A new beautiful white Mignonette, compact habit, very sweet scented. Carefully selected seed...1/4 oz., $50 \mathrm{cts}$.

Orange Queen. A highly improved sort with monstrous spikes, beautifully colored, orange and pale yellow ....... Oz., $50 \mathrm{cts}$. All sorts mixed .............................., 30 cts.

\section{MATRICARIA (Feverfew)}

Snowwhite. Very double pure white flowers borne in greatest profusion on a compact bush 30 inches high. The bright green foliage is finely cut like fennel. Fine for cutting. Lasts a long time.

$1 / 4$ oz., 25 cts.

\section{MARVEL OF PERU (4 o'clock)}

One of the oldest Grandmothers' garden plants. It grows 2 to 3 feet tall, in bush form covering a space fully 18 inches wide. The whole plant is covered with bright flowers which close toward evenwhole plant is covered the bright morning light. Especially fine on ing, opening only to the bright morning light. Especially fine on sunny days. Colors range in white, rose pink, violet, sulphur to
red. Sow seeds where you wish plant to bloom ......Oz., 25 cts. .

\section{MATHIOLA BICORNIS \\ EVENING SCENTED STOCK}

This is a specially delightful plant. The flowers emit in the morning, and evening, especially after a slight rain, the most delicious ing, and which is perceptible for quite a distance from the plant. pcatter the seed freely in any available spot especially in wild garden.

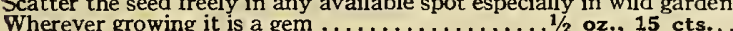

\section{NEMOPHYLLA}

\section{CALIFORNIA BLUE BELL-BABY EYES}

A lovely, hardy annual, especially useful for ribbon borders, small beds, wild gardens. Charming for rockwork, should be grown everywhere. Strikingly clear azure, wonderfully soft and fresh, blue with white eye. Ht. 10 inches. Oz., 25 cts.; pkt., 5 cts.

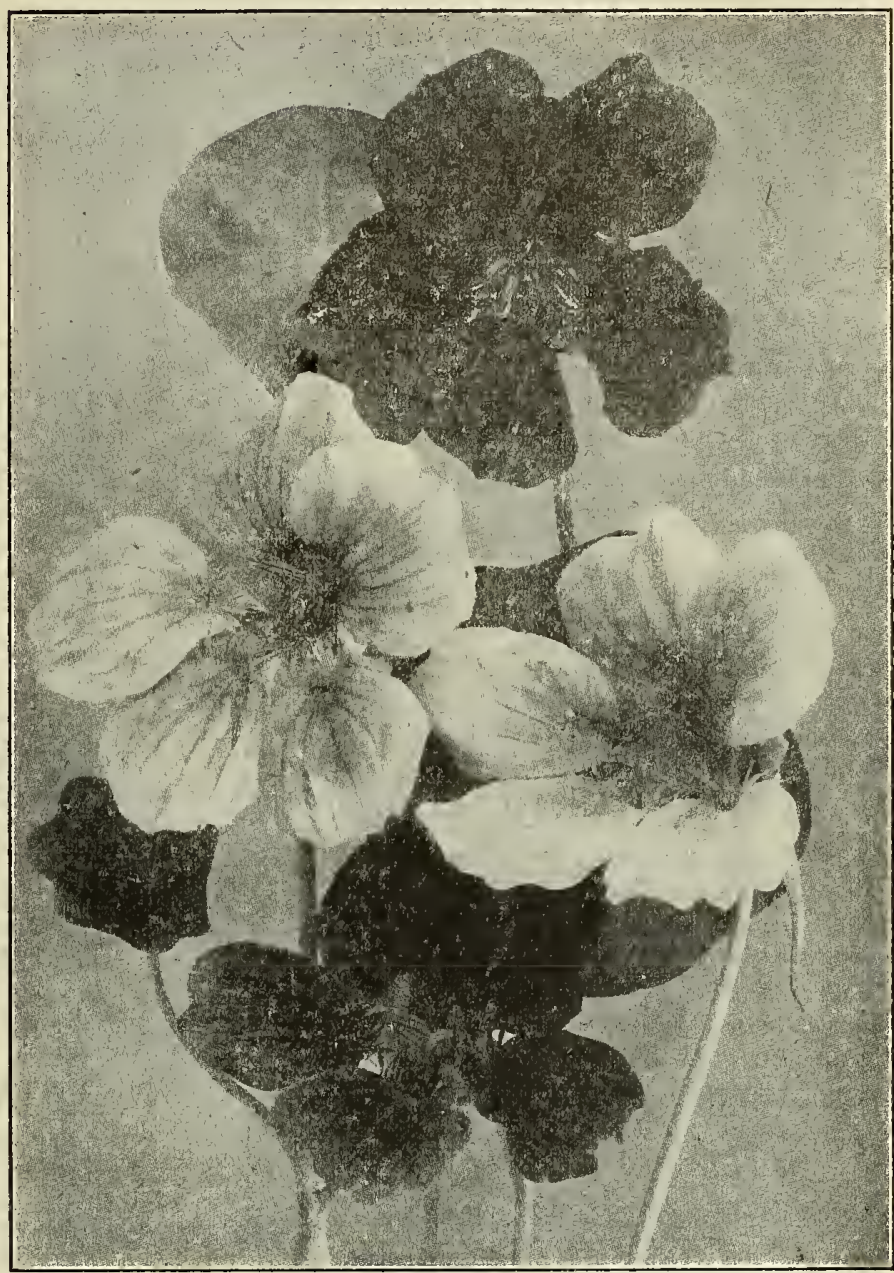

Nasturtiums

\section{NASTURTIUMS}

TALL OR CLIMBING 6 to 10 feet
.10

.05 Elegant ans railings and to trail over rough ground with fine effect. The seed pods can be gathered while green and tender for pickling The varieties we list should not be confounded with the common tall Nasturtiums, as they surpass them by far in the remarkable brilliancy of the flowers.

For ease of culture, duration of bloom, brilliancy of coloring and genera! .05 excellence nothing excels Nasturtiums. All they need is a moderately good soil in a well-drained, sunny position, and within a few weeks from the time they are sown until hard frost comes there is an endless profusion of their gorgeous blossoms. The maximum of bloom is produced in light or sandy soils and seldom diminishes through the hot weather.

1/4 lb. Oz. Pkt.

Brilliant. Bright scarlet ...............\$0.60 \$0.15 \$0.05 Chameleon. Various richly colored flowers, one stem $\quad .60 \quad .15 \quad .05$ Chocolate. Very odd shade of bright golden brown. $\quad .60 \quad \begin{array}{lll}6 & .05\end{array}$ Hemisphericum. Straw color, rosy blotched $\ldots .60 \quad .60$ Moonlight. Beautiful creamy white $\ldots \ldots \ldots \ldots \ldots .60 .15 \quad .05$ King Theodore. Deep maroon, dark foliage .... $.60 \quad .15 \quad .05$ Regelianum. Rich velvety violet, crimson........ $.60 .15 \quad .05$ Sunlight. Pure rich orange $\ldots \ldots \ldots \ldots \ldots \ldots \ldots \ldots .60 \ldots \ldots$ Rose. Bright rose with brilliant scarlet, foliage Vesuvius. Rare glowing salmon pink .............. $.60 \quad .15 \quad .05$ 


\section{LOBB'S NASTURTIUMS}

TALL OR RUNNING SORTS. 6 to 10 feet

Asa Gray. Creamy primrose color ........... $1 / 4 \mathbf{~} \mathbf{6 0}$

Atropurpureum. Dark purple ........... 60

Aureum. Golden Queen (new) .............6.

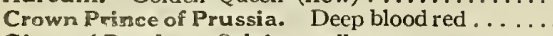

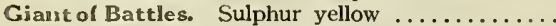

Duc de Vincennes. Pale sulphur yellow ........

Ivy Leaved. Bright crimson scarlet, with dark
metallic colored foliage most useful for vases,

hanging baskets, or window boxes and vases .....

Queen Helena. Terracotta, very effective and

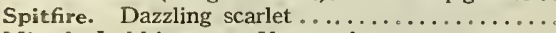

Mixed Lobbianum Nasturtiums.........

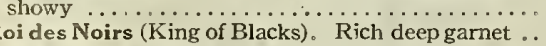

$\begin{array}{rr}\text { Oz. } & \text { Pkt. } \\ .15 & .05 \\ 15 & .05 \\ .15 & .05 \\ .15 & .05 \\ .15 & .05 \\ .15 & .05 \\ & \\ .15 & .05 \\ .15 & .05 \\ .15 & .05 \\ .15 & .05 \\ 10 & .05\end{array}$

\section{DWARF VARIETIES OF NASTURTIUMS}

Aurora. Primrose, veined carmine. Ht. 1 foot... $.60 \quad .15 \quad .05$

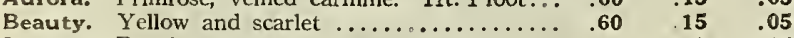

Bronze. Burnished bronze color ............... $60 \quad .15 \quad .05$

Chameleon. Various shades of yellow and red $60.15 \quad .05$

Empress of India. Brilliant dark crimson flowers,

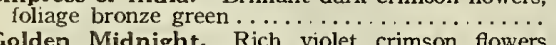

Golden Midnight. Rich violet crimson flowers
nestling in bright golden leaves .............

King of Tom Thumbs. Compact growth, vivid

scarlet, dark foliage $\ldots \ldots \ldots \ldots \ldots \ldots \ldots \ldots \ldots$

Ying Theodore. Velvety maroon $\ldots \ldots \ldots \ldots \ldots \ldots$
Pearl. Creamy white $\ldots \ldots \ldots \ldots \ldots \ldots \ldots$

Ruby King. Fine deep ruby rose ............

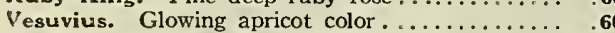

Golden Rose. Beautiful pink ................6. 60

Queen of Tom Thumbs. Rosy scarlet blossoms,

amidst silvery variegated foliage ............

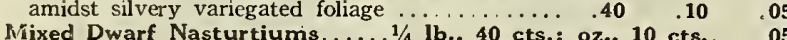

\section{NASTURTIUMS LILLIPUT}

These are very exquisite dwarf species of Nasturtiums. Ht. 5 to 6 inches. They are specially fine for vases, window boxes, edging, and bedding. Flower continually and profusely.

Snowqueen. Pure white.

$\$ 0.75 \quad \$ 0.20 \quad \$ 0.10$

Lady Cherry. Deep ruby red .............. 75

Baby Rose. Cream white and pink spotted. Splen-

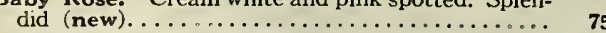

Mixed Lilliput Nasturtiums ,........... 60

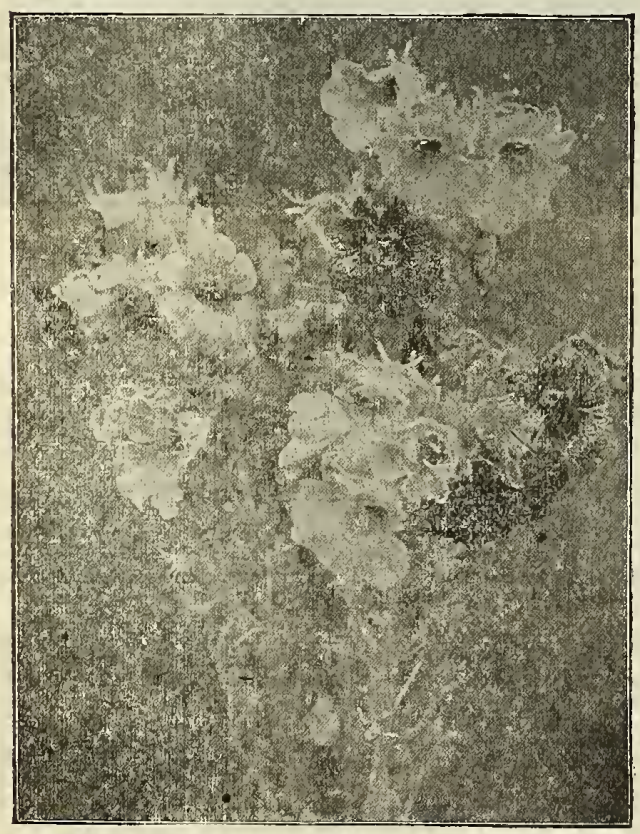

Nemesia Strumosa
$.20 \quad .10$

$.20 \quad .10$

1505

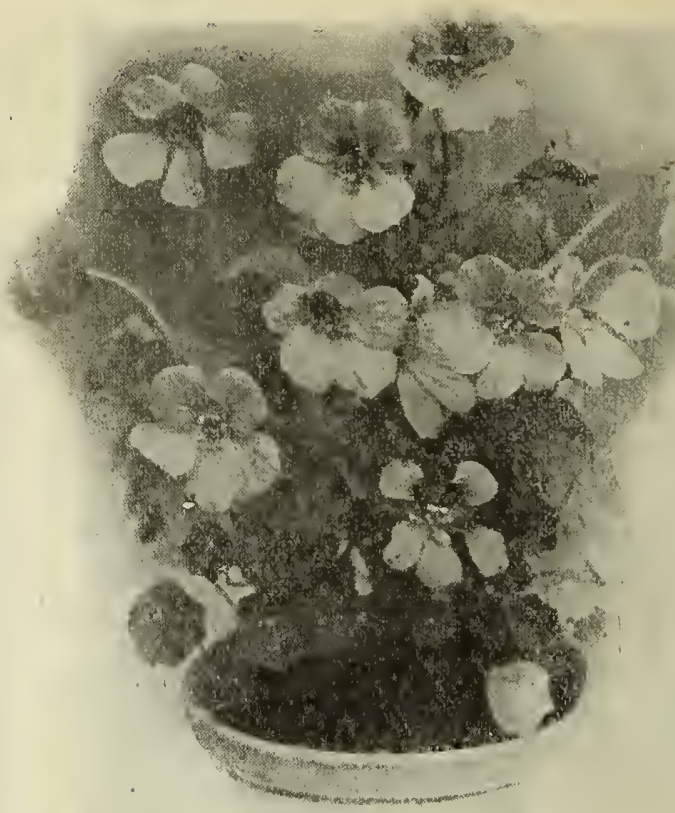

Nasturtium - Fire King

Pist.

Nasturtium Tom Thumb Fire King. A new and distinct variety. Flowers a deep orange-scarlet, showing well above the small dark green foliage, and very free-flowering and compact. A grand advance in dwarf-bedding Nasturtiums. We can strongly recommend this variety, being in our opinion the finest that has yet been mend this variety, being in our opinion the finest that has yet been

\section{NICOTIANA}

Grows to a height of 3 feet bearing on branching stems in great abundance single, pure white, tubular flowers, fully 3 inches in diameter. These flowers remain closed through the day, opening only mornings and evenings when they exhale a most delicious perfume. The foliage is long and bright green. The plant is very attractive.

Nicotiana affinis. Pure white...........1/4 oz, 25 cts

\section{NICOTIANA SANDERI}

These Hybrids are in every respect like the Affinis sorts, but are not fragrant. The colors range through rose carmine crimson to violet. The plants grow 3 feet tall forming a large bush. Very ornamental. $1 / 4$ oz., 35 cts.; Pkt., 10 cts.

\section{NEMESIA}

Half hardy annuals of great beauty. The colors are as gorgeously beautiful as a sunset, and as varied.

Strumosa Suttoni. Rich sunset shades. Ht. 15 inches. Trial pkt., 10 cts.; pkt., 25 cts.

Strumosa Grandiflora Tigrina. Striped and marbled. Unsurpassed in glowing effect of coloring. Trial pkt., 10 cts.; pkt., 25 cts.

Novelty Nemesia Blue Gem. An exquisite plant for massing or edging. Ht. 10 inches covered with azure true blue flowers. A gem of the garden. Trial pkt., 10 cts.; pkt., 25 cts.

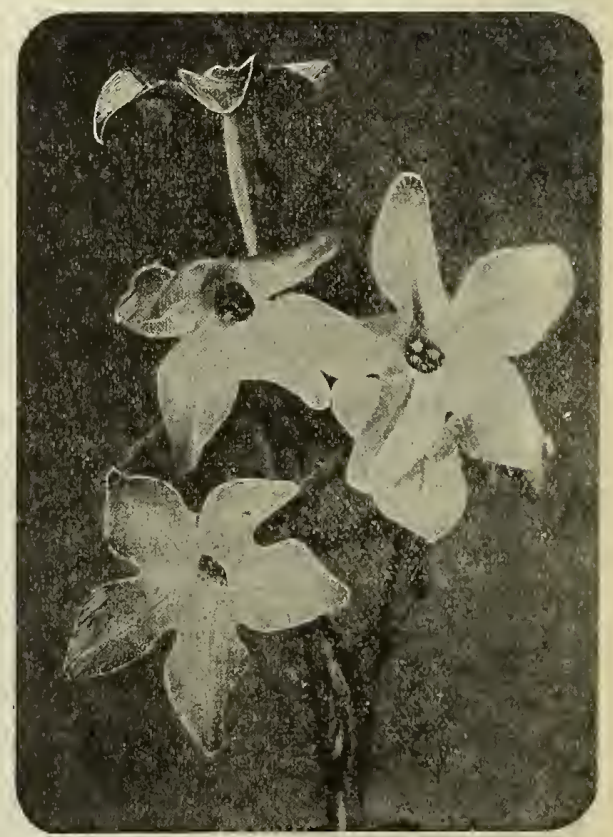

Nicotiana Affinis 

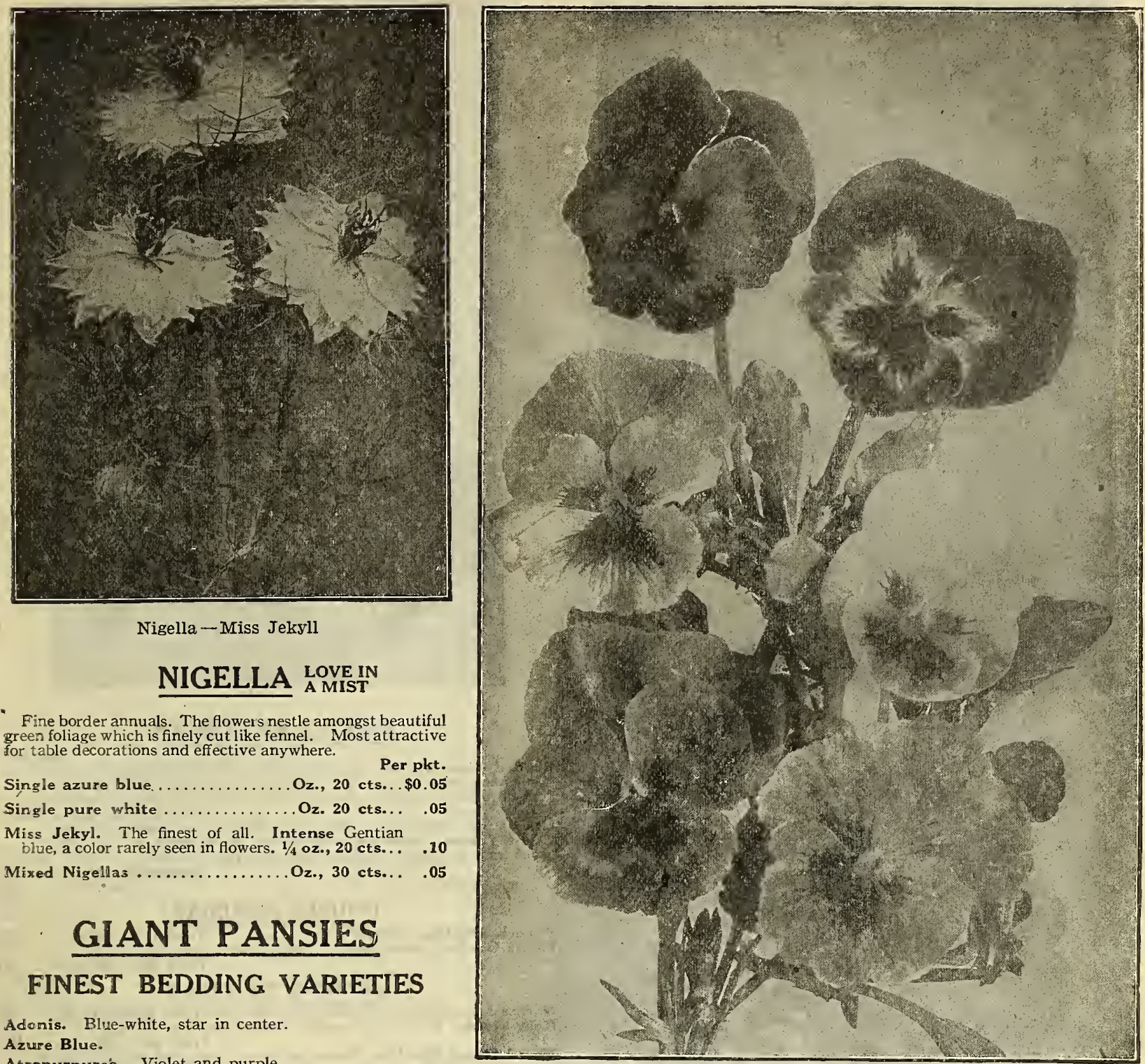

Fine border annuals. The flowers nestle amongst beautiful green foliage which is finely cut like fennel. Most attractive for table decorations and effective anywhere.

Per pkt. Single azure blue............ Oz., 20 cts. .\$0.05 Single pure white ............ Oz. 20 cts... .05 Miss Jekyl. The finest of all. Intense Gentian blue, a color rarely seen in flowers. $1 / 4$ oz., 20 cts... .10

Mixed Nigellas ............... Oz., 30 cts... .05

\section{GIANT PANSIES}

\section{FINEST BEDDING VARIETIES}

Adonis. Blue-white, star in center.

Azure Blue.

Atropurpuréa. Violet and purple.

Faust. Deep velvety maroon.

Striped and Spotted.

Cardinal. Most brilliant red.

Coquette de Poissy. Pale rosy mauve, very striking.

Emperor William. Bright blue.

Emperor Frederick. Dark red, bordered orange scarlet.

Fire King. Golden yellow, upper petals crimson.

Gypsy Queen. Terracotta and bronze.

Fairy Queen. Azure blue, white edge.

King of the Blacks. Deep dark almost black.

Snow King. Pure white.

Camary Bird. Pure yellow.

Golden Yellow. Large deep yellow with black eye.

Lord Beaconsfield: Rich plum blue and lilac.

Meteor. Bright terracotta.

Madame Perret. All ruby red and crimson shades.

Giant Trimardeaus. Yellow shades with blotches.

Wall flower shades. Dark brownish red and gold.

Peacock. Reddish steel blue with red and white edge; most beautiful.

Victoria. Claret red.

White with dark eye.

Any one of above, oz., $\$ 1.50 ; 1 / 4$ oz., $50 \mathrm{cts}$; pkt., $10 \mathrm{cts}$.

One packet each of twenty-four sorts, twenty-four packets, $\$ 2.00$.

Berger's Grandest Mixture. 1/4 oz., 30 cts., oz., $\$ 1.00$; pkt., 5 cts.

\section{GIANT STRAINS OF SUPERB PANSIES}

Bugnot's Superb Blotched. Immense flowers of finest shades with deeper blotches on each petal.

Cassier's Golden Yellow. Superb blotched.

Masterpiece (Germania). Richest shades curly petals, dark blotcnes.

Matchless. Most exquisite shades ranging from sulphur yellow to an exquisite rich claret and reddish bronze. All are beautifully edged and blotched, the surface of petal of the richest velvety sheen. The blooms are of immense size with grand substance, free from any coarseness or flimsiness. The plants are of exceptionally strong sturdy habit with large green foliage. It is in every way the ideal pansy for exhibiwith large green foliage.
tion or in the garden.

Curled. A magnificent new type, flowers large, finely curled and fimbriated, so much so as to appear a double flower. This flower comes true to type from seed and cannot be too highly recommended.

Psyche. Flowers curled and undulated; rosy violet, surmounted by a broad white edge, dark blotches.

Orchid Flowered Mammoth. New Type. Light cream shades, with beautiful dark blotches.

Empress strain. Saved from prize flowers containing a truly remarkable variety of the largest flowers and richest strains of colors

Any packet of the above listed sorts for trial, 10 cts. Large pkt., 25 cts. One packet of each of the sorts, eight trial packets, $70 \mathrm{cts}$.

Above sor is mixed, pkt., $10 \mathrm{cts.;} 1 / 8$ oz., $\$ 1.00$ 


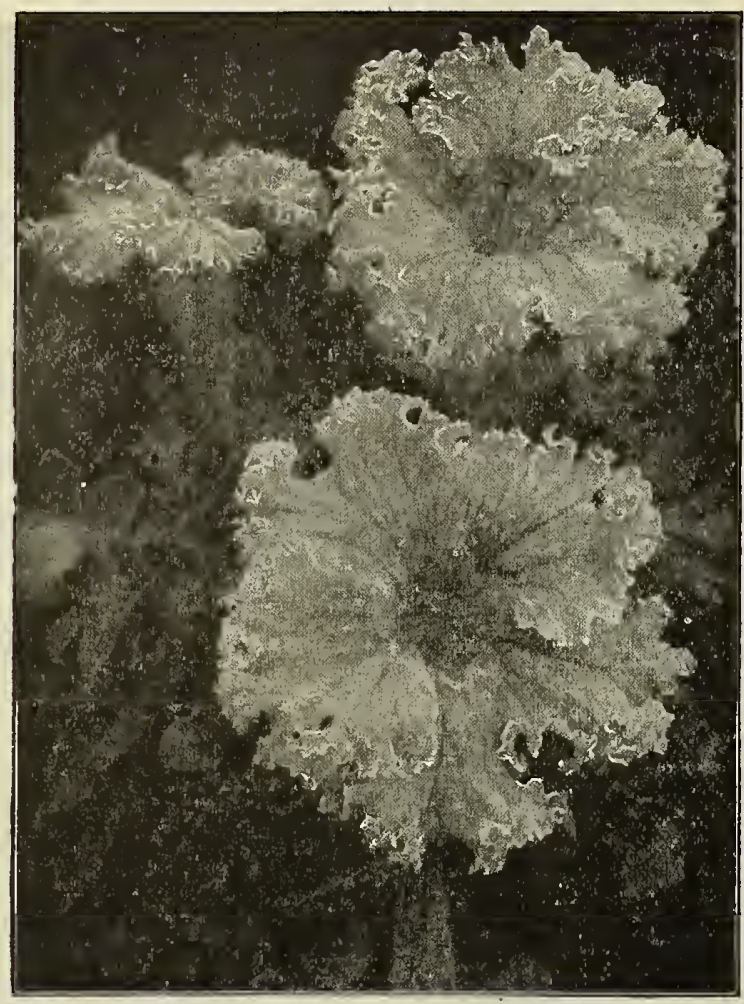

Ruffled Single Petunia

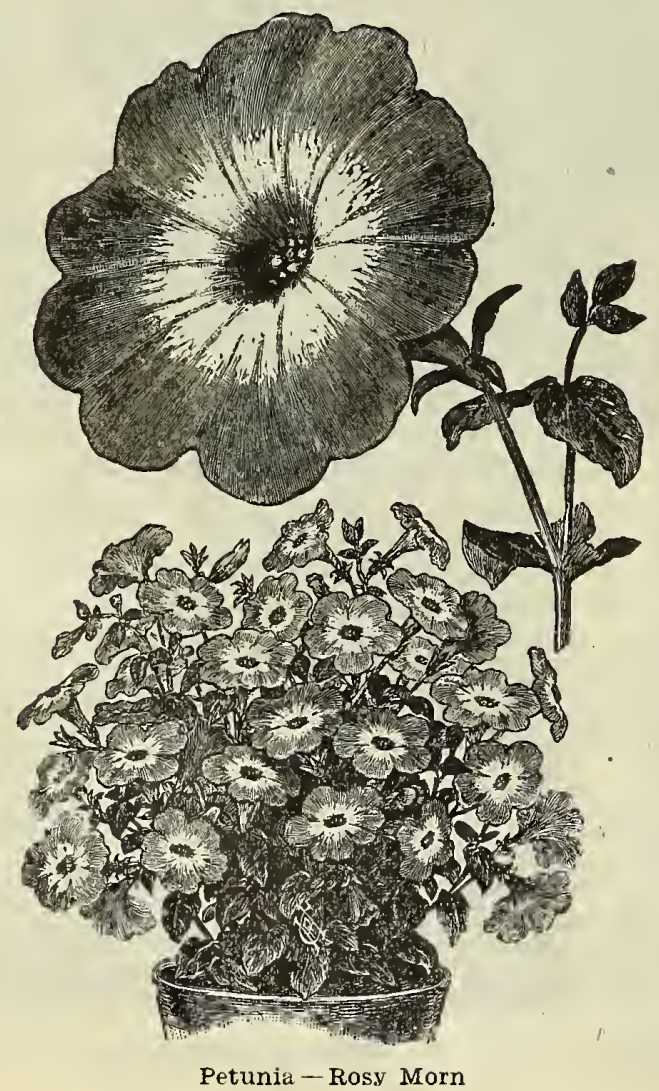

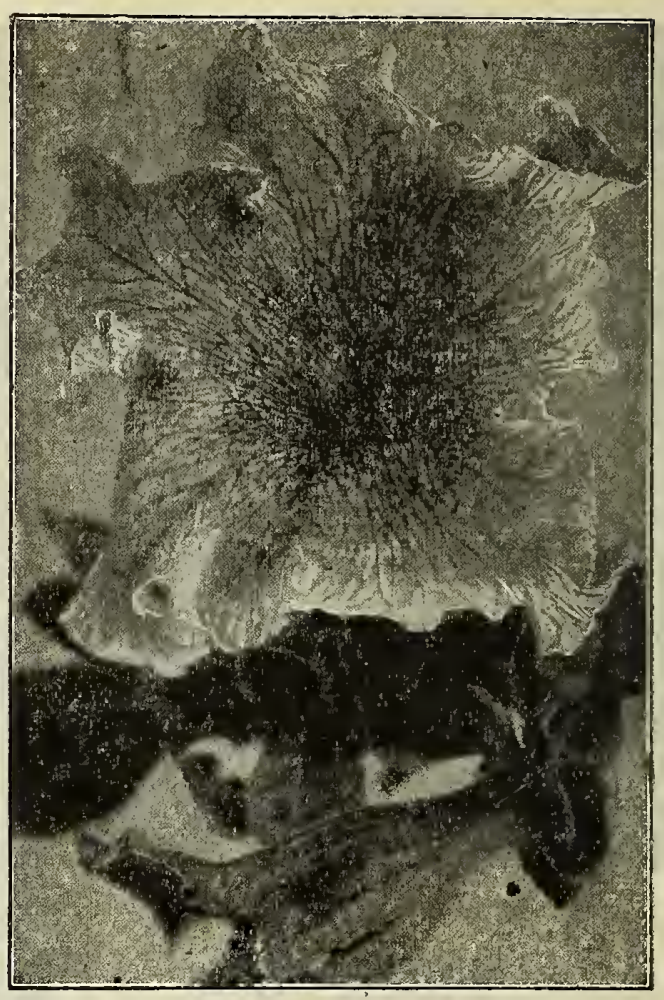

\section{SINGLE PETUNIAS}

Ruffled Giants. The edges are deeply ruffled and futed, Per pkt: substance with deep, wide throats, varying in color from pure white to deep purple violet. Many of them are beantifully striped and veined ........................... Trial pkt., $10 \mathrm{cts.} . \$ 0.25$ Giants of California. Enormous flowers in delightful shades. Giant Yellow Throated. The flowers are immense, of the richest

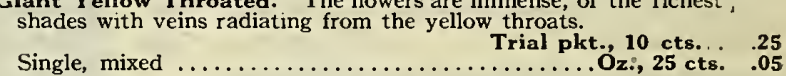

\section{DOUBLE PETUNIAS}

Superb Double, fringed ............Trial pkt., 25 cts... $\quad .50$ Giant Double, plain edge. Magnificent colors. $\begin{array}{rll}\text { Trial pkt., } 25 \text { cts... } & .50\end{array}$

\section{BEDDING PETUNIAS}

Norma. Deep blue with white star. Ht. I ft. Trial pkt., 10 cts... $\quad .25$ Rosy Morn. Brilliant rose with white throat, very beautiful.

Mixed Dwarf Bedding Petunias, very bushy, producing a most lovely effect for bedding and borders.... Trial pkt., 10 cts... . 25

\section{PHLOX DRUMMONDI, GRANDIFLORA}

This is the finest type, having the largest heads of bloom, as well as the largest individual flowers; of strong, sturdy growth. Ht. 15 inches.

It will grow and thrive in any kind of soil if given a sunny position, but prefers a light, rich loam. Seed may be sown in the open ground any time after danger from frost is past, and in a few weeks they are a sheet of bloom, remaining so until frost.

Snow White. ........................1/4 oz., 40 cts... .10

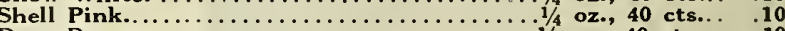

Deep Rose............................1/4 oz., 40 cts... .10

Bright Scarlet...........................1/4 oz., 40 cts... .10

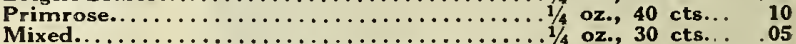

\section{PORTULACA}

Veritable jewels in the garden where they bloom in an incredibly short time after being sown. They literally cover the ground with a carpet of dazzling colors. For very dry, sun exposed places, for rockwork, and especially on the seashore for bedding, nothing equals them. Portulacas attain only a height of 6 inches, are of a creeping nature, and the foliage is of a succulent bright green, mostly covered by the large shining flowers. Plant them largely. Nothing could be finer.

flowers. Plant them largely. Nothing could be finer.

DOUBLE FLOWERING PORTULACA

The flowers are like Ranunculus, very dnuble.

Brilliant shades mixed . 


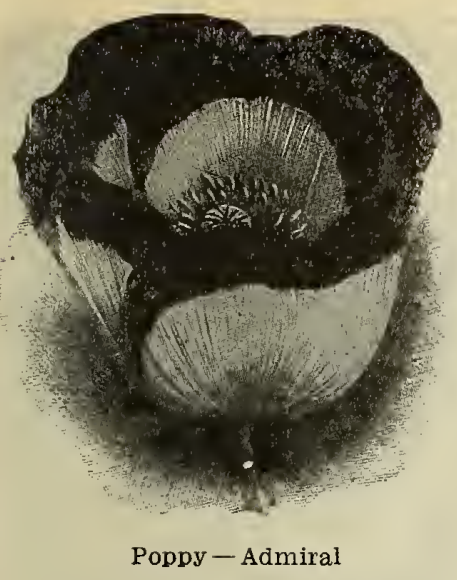

\section{POPPIES}

"All silk and flame, a scarlet cup seen amongst the wild grass far away, like a burning coal fallen from heavens afar. You cannot have a more complete, a more stainless type of, flower, absolute inside and outside-all flower."-(Ruskin.)

One of the grandest Garden Annuals and Perennials. So easy to grow, the mere throwing of seed on the ground will bring forth their gay flaunting colors; the silky petals waving in the passing breezes. Masses of beautiful Hybrids have been evolved vieing with each other in glorious beauty. The seed of all may be sown in early spring and in intervals as late as July, where continuous display is desired. Let us talk to you about some of the very beautiful varieties. We cannot list them all.

Poppies are especially adapted to cultivate on the Poppies are especially adapted to cultivate on the seashore where they thrive wonderfully well. Poppies will not bear transplanting but must be sown where they are to hlower (This refers to annual sorts). Do not sow poppy seed too deep as this will keep them from sprouting freely. Scatter over well prepared, smooth soil and sift a very thin layer of soil over the seed just covering it. Spray only with a fine rose.

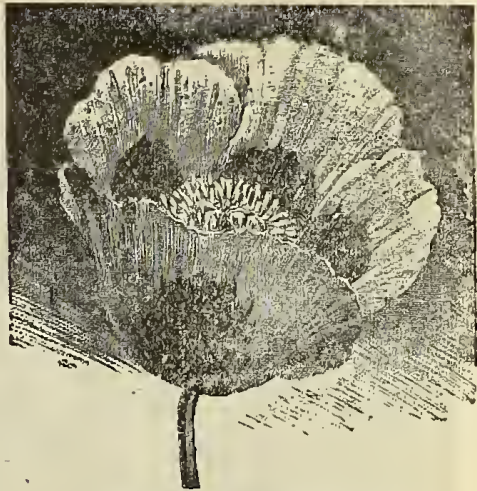

Poppy-Dainty Lady

\section{SINGLE FLOWERING POPPIES}

The Bride. Immense single white $\ldots \ldots \ldots \ldots \ldots$ oz., 25 cts. $\ldots \$ 0.05$ English Field or Scarlet Poppy. Large fiery scarlet. $1 / 4$ oz., 25 cts.; oz., 65 cts.

Poppy Admiral. The flowers are large, round, smooth edged, of the purest white, with a broad band of brilliant scarlet around the top occupying a full quarter of the corolla. These two colors form a startling contrast similar to those seen in variety Danebrog. Planted in groups this new Poppy produces a magnificent effect

$1 / 4$ oz., 15 cts.; oz., 50 cts. .

Danebrog, or Danish Cross. Very showy variety, producing large single flowers of brilliant scarlet, with a silvery-white spot on each petal, thus forming a white cross..1/4 oz., 10 cts.; oz., 25 cts.

Poppy "Dainty Lady." We can recommend this Poppy for the particularly beautiful color of its single flowers, a most charming shade of rosy mauve, not yet represented among Poppies and one of those modern hues now so much sought for. The effect is further oightened by the shining dark metallic blotch which occupies the base to the middle of each petal. The Dainty Lady Poppy grows about 2 feet high, is clothed with broad laciniated glaucous foliage and bears flowers from 4 to 5 inches across. It is of the easiest culture, excellent for bedding and cutting, and comes true from seed. $1 / 4$ oz., 10 cts.; oz., 40 cts. .

Virginian Poppy. This new large flowering Single Poppy is an annual, producing immense white flowers, with a deeply fringed rose pink edge. It produces a charming effect in the garden, and is unique as a cut flower for decorations, especially if cut when the buds show color. It will last many days in water.

$$
1 / 4 \text { oz., } 15 \text { cts.; . oz., } 50 \text { cts. . }
$$

Tulip Poppy (Papaver glaucum). Like a scarlet Van Thol Tulip. A fascinating sort, 15 inches high, glowing fiery scarlet, cup an saucer form ...............1/4 oz., 25 cts.; oz., 60 cts.

Mixed Annual Poppies. Representing the best in single poppies. $1 / 4$ oz., 15 cts.; oz., 25 cts.; 1/4 lb., 75 cts..

\section{DOUBLE FLOWERING POPPIES}

Carnation flowered. Large double flowers, finely fringed of many brilliant tints. Ht. $2 \frac{1}{2}$ feet ............ $1 / 4$ oz., 15 cts.

Pronia flowered. Immense globular flowers excellent for border amongst shrubbery, etc. Very showy. Ht. $2 \frac{1}{3}$ feet

$$
1 / 4 \text { oz., } 15 \text { cts.; oz., } 50 \text { cts.. }
$$

Japanese Pompon. Size of Pompon Dahlias. Very fine free flowering, double. Ht. 2 feet. . . 1/4 oz., 15 cts.; oz., 50 cts..

The Cardinal. Large double, bright scarlet finely fringed flower. Very fine..................1/4 oz., 15 cts.; oz., 50 cts..

French Ranunculus Poppies. Mixed colors, most brilliant. Ht. 2 feet. . .............1/4 oz., 10 cts.; oz., 35 cts.

.05

.05

05

05

05

10

.05

05

05

.05

05

05

\section{NOVELTY IN RANUNCULUS FLOWERED POPPIES}

Salmon rose to orange shades. One of the greatest acquisitions to the Poppy class. Through the whole gamut of tints lying between pale salmon rose to deep orange, these exquisite Poppies are now a fixed sort. They are of the easiest culture, growing with almost no care, and giving an abundance of their beautiful blooms. The gorgeous flowers cut just before opening will expand in water and last several days. Planted amongst shrubbery or in the open border, in groups or in beds, the rich colors of the flowers form a point of at -

All sorts double flowering Poppies mixed.......... oz., 30 cts. .

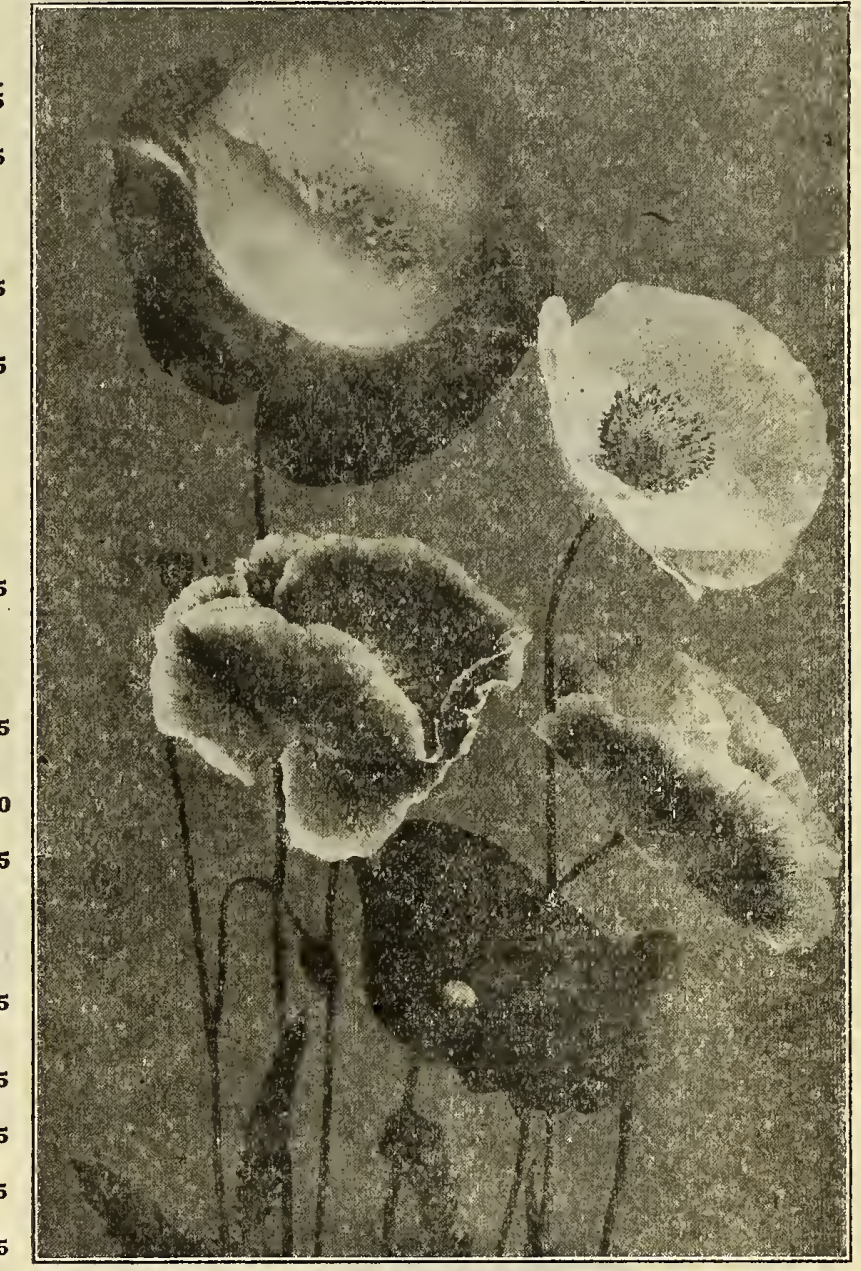

Shirley Poppies

\section{SHIRLEY POPPIES}

The most exquisite single Poppies in existence. Silky, shining petals varying in all colors of the rainbow, the effect created by these lovely flowers is hard to describe and must be seen to be fully appreciated. In separate colors.

Rose

White

Carmine
Apricot

Scarlet

Pink with frilled edge Per pkt. oz., 50 cts.; $1 / 4$ lb.. $\$ 1.50 \ldots \$ 0.10$ .05

Collection of the six sorts listed, 50 cts.

Mixed Shirley Poppies ........oz., 40 cts.; $1 / 4$ th.. $\$ 1.25 \ldots . .10$ 


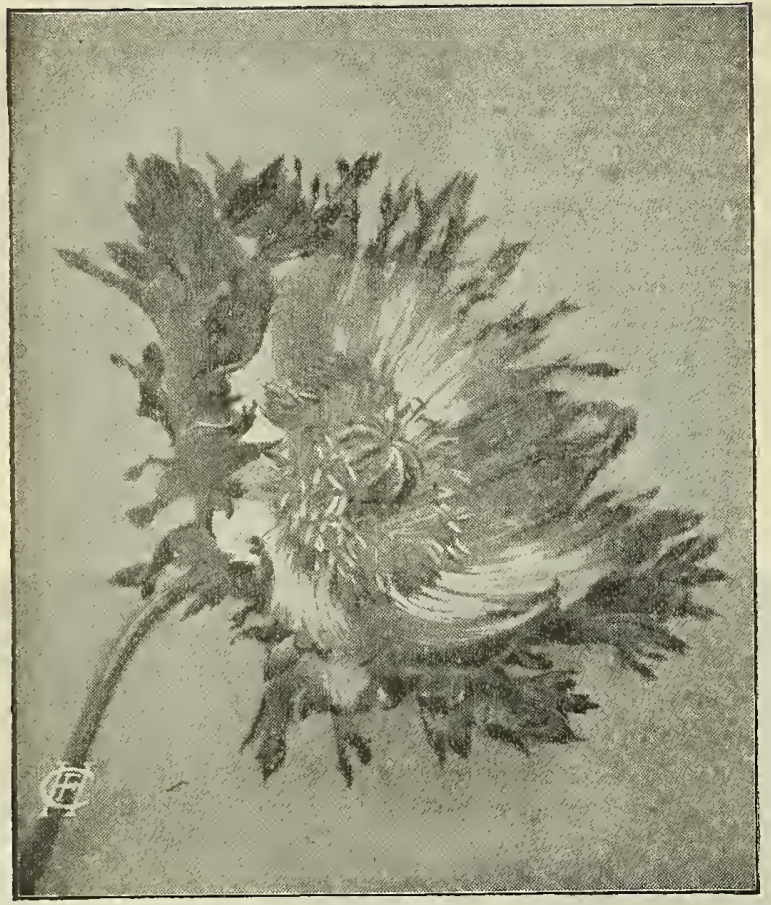

Poppy-Hansa

POPPY HANSA

As picture shows, a valuable addition to the Poppy Garden Per pk flowers have a pure white ground color, passing toward the finely Jaciniated edge to a deep rich crimson. A most brilliant and fascinating flower. Raised with the greatest ease. Trial pkt., 10 cts..\$0.25

\section{RICINUS CASTOR OIL}

Remarkable for their immense tropical looking foliage of various tints, and the bright colored fruits following the blossoms in fall. They are much used for centres in beds or amongst shrubbery in the border. Whereever grown they have a majestic and striking effect. They grow rapidly
from seed.

Gibsoni, handsome bronze colored stem and foliage. As the leaves mature they assume a rich bronzy blue white, the veins run through them like rivulets of crimson flame. The underside is a dull rich crimson. Ht., 5 feet......................, 25 cts.. $\$ 0.05$ Borbonensis arboreus. Hit. is feet. Very tall sort with purplish

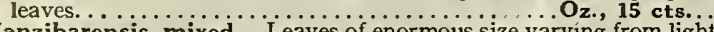
green to purplish red............. Oz., 10 cts.; $1 / 4$ lb., 60 cts... anguineus. Very fine sort with red stems and reddish purple leaves. Ht. 10 feet. ..........., $10 \mathrm{cts.} ; 1 / 4 \mathrm{lb}$, $25 \mathrm{cts...} .05$ Choice mixed....... Oz., $10 \mathrm{cts.;} 1 / 4$ lb., 25 cts.; lb., $75 \mathrm{cts} . . .05$

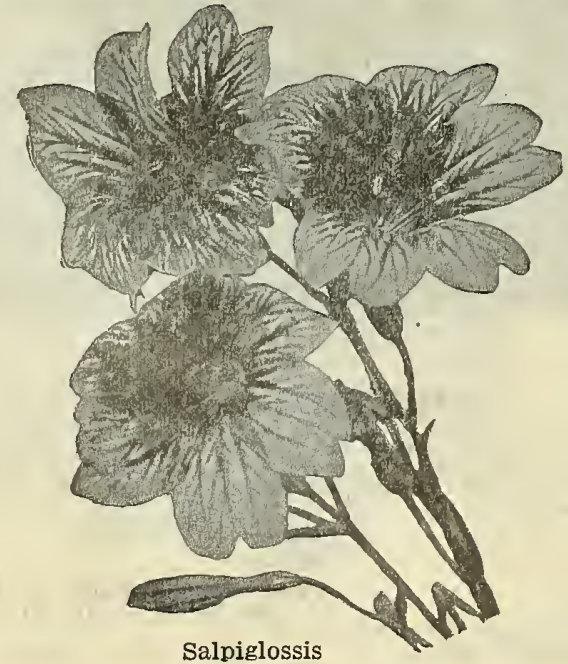

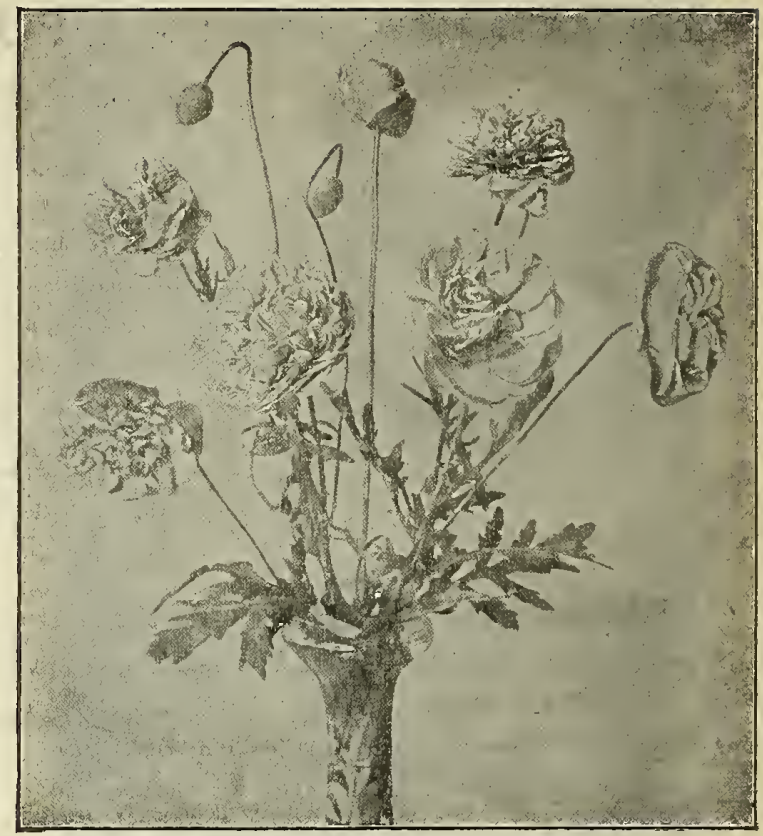

Double Ranunculus Flowering Poppy

RUDBECKIA SUPERBA HYBRIDA. New hybrids of the multicolor, splendid, annual Rudbeckia. The forms of the flowers are manifold; some have broad, others twisted petals, some are single flowering, some semi-double and others quite double. Also the colors, respectively the designs vary, so that these new hybrids are very useful and give good effect both for borders and for groups.

Pkt. $1 / 4$ oz., 25 cts..

\section{SCABIOSA}

Velvety Pincushion Flower (Egyptian Rose, etc.). One of the most magnificent hardy annuals, whose free blooming qualities, large showy flower heads, and easy cultivation have placed it in the forerank of favorite plants. Very decorative in borders and beds, the beautiful flowers are most useful for cutting and decorations, lasting for many days in water The range of colors is wonderfully large. Where early bloom is wanted, start in the house early in season, February-March. Sown in the open the plants bloom late July till frost. They must not be kept too wet.

\section{TALL LARGE FLOWERING DOUBLE}

The Bride. Pure white

Cherry Red

White and Lilac

Deep Violet

Pompadour. Claret purple, edged white

Any of the ten colors separate.............1/4 oz., 20 cts... . 10 The collection of ten colors, ten packets, 85 cts.

All colors mixed, Scabiosa......1/4 oz., 20 cts.; oz., 75 cts... .10 Novelty. Azure Fairy Scabiosa. A delightful rich light blue shade, very large double flower. A gem in the collection. Trial pkt., $10 \mathrm{cts} . . .20$

\section{SALPIGLOSSIS \\ ADDER'S TONGUE}

For gorgeous coloring few flowers can match this lovely species. The vivid shades are marked with contrasting veins and pencilled, attract the eye and give a marvellously' rich effect.

In separate colors:

Giant Brilliant Scarlet

Giant Brown with Gold

Giant Light Blue with Gold

Giant Sulphur Yellow

Giant Blood Crimson

\section{Golden \\ Velvety. Violet \\ Rose \\ White and Gold}

$1 / 8$ oz., 25 cts... . 18

Collection of ten sorts, 10 pkts., 75 cts.; 5 pkts., 40 cts.

All colors mixed. 1/8 oz., 20 cts.; Pkt., 5 cts. 


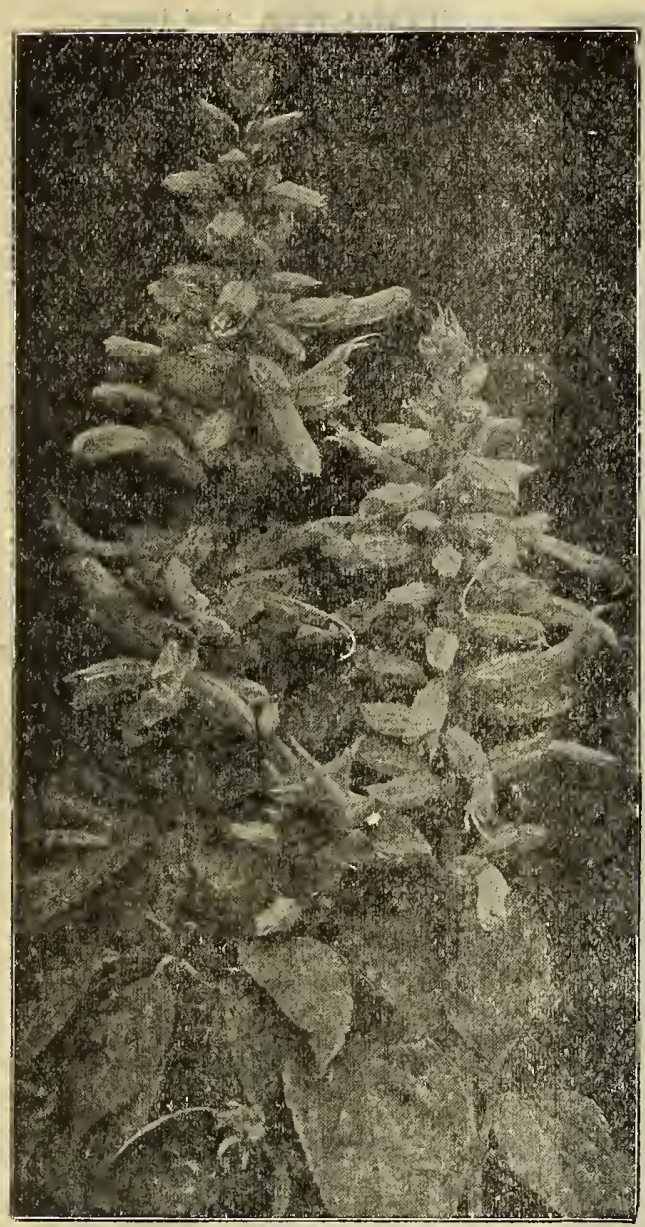

Salvia Caṇary Bird

\section{SALVIA}

SCARLET SAGE

Might well be called Flaming Bush, as the fiery colors are marvelous and can be seen for long distances. They are very easily raised from seeds in the hothouse or in boxes in the house, early in February and March, when the young plants will bloom in July. Later sow in open when they will bloom in August all through season till frosts appear.

Splendens. A very tall growing sort with immense flower trusses of fiery scarlet Ht. 3 feet. $1 / 8$ oz., 40 cts. ; pkt., 10 cts.

Splendens Bonfire. A magnificent sort with very full flowerspikes of brilliant scarlet. Ht., 2 feet. $1 / 8 \mathbf{~ o z}$. 75 cts.; pkt., 10 cts.

Zuerich. Free flowering Dwarf sort with erect spikes covered thickly with bright scarlet flowers. Ht. 12 to 15 inches. These plants begin to bloom very early and continue throughout season. $1 / 8$ oz., 75 cts.; pkt., 10 cts. Fireball. Really the finest of all early and free blooming Salvias. It produces profusely long spikes of flowers thrown well above the foliage, a thousand times more vividly scarlet than any Geranium, being one of the most decorative and showy bedding plants. $\mathrm{Ht}$. $1 \frac{1}{2}$ feet. $1 / 8$ oz., 75 cts.: 12 feet. 10 cts.

Triumph (New). Extra early velvety scarlet, very large flowers. A gem for border and bedding. Trial Splendens Carminea. A Splendens Carminea. A
new tint in this lovely flower new tint in this lovely flowcr
Rosy carmine. Ht. $1 \frac{1}{2}$ feet. Trial pkt., 10 cts.; pkt., 25 cts.

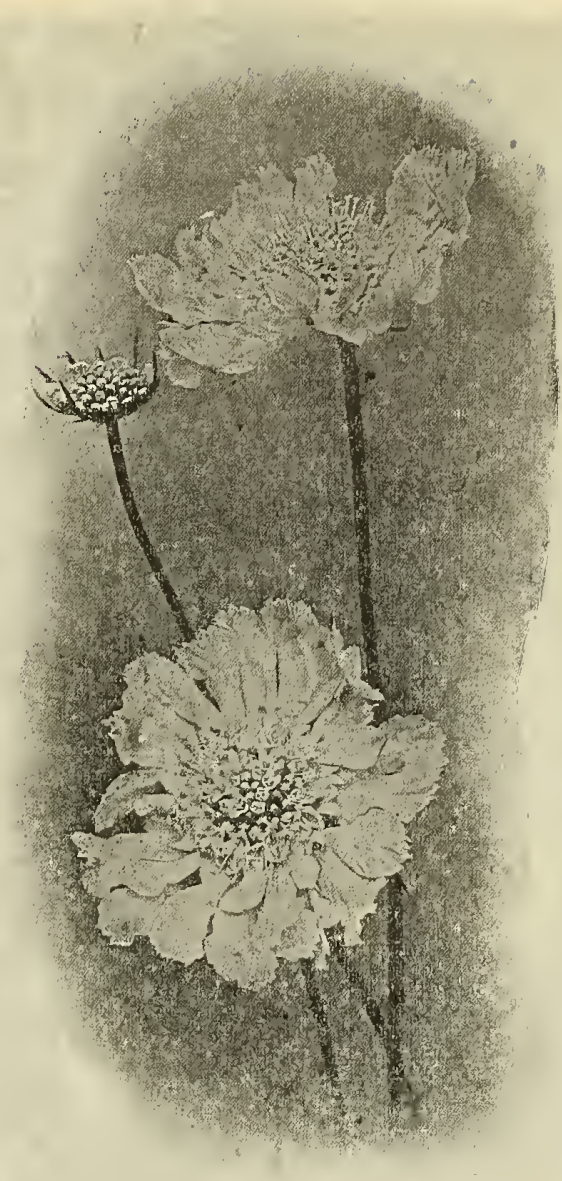

Scabiosa
Novelty Salvia Canarybird. Unique canary yellow flowers, velvety dark green foliage. Striking and beautiful. Trial pkt., 10 cts.; pkt., 25 cts.

\section{STOCKS}

\section{GILLIFLOWERS. LEVKOYEN}

Who does not know this magnificent plant whose fragrance perfumes whole garden and whose delightful blooms enrich our winter gardens? Sow for early bloom in the house February to March. For later summer sow where the plants are to bloom. Thin out when seedlings are 2 to 3
inches high. The seeds we offer are all specially selected, and will produce a large percentage of double rosetted flowers.

\section{IMPROVED CUT AND COME AGAIN}

These splendid stocks will bloom throughout the whole summer if sown in succession and started early in season. Ht. 18 inches.

Princess Alice. White Mammoth. Blood red

Chamois Rose Bluebird. Light blue

Canarybird. Canary yellow Violet. Dark blue
Rosy Peachblossom

In separate colors In separate colors .......................... 75 oz., $\$ 1.00 \ldots \ldots 10$

All colors mixed $\ldots \ldots \ldots \ldots \ldots \ldots \ldots \ldots \ldots \ldots \ldots \ldots 1 / 8$ oz., $\$ 1.00 . \ldots .10$

\section{PERFECTION STOCKS}

For summer and autumn flowering. Ht. 18 inches. A very sturdy, robust sort, of branching habit. The flowers are large, very decorative lasting a long time. Invaluable for cutting and decorations. Bloom throughout summer till frosts

Fireball. Dazzling scarlet

Light Blue

Deep Purple

Mauve Queem

Each color separate

Rose

Dark Blue

Snow White

Collection of eight sorts, eight packets, 75 cts

$1 / 8$ oz., 75 cts.

Mixed colors

\section{WINTERFLOWERING STOCKS}

These sorts are called Winterflowering as they are the very bcst variety for that time although they bloom equally well from spring till fall in the open. They are by far the very handsomest and showiest. If sown early in the season they will flower all through summer till heavy frosts cut them down. They are of robust branching habit with immense spikes of fragrant flowers, richly scented, and are found in the most delicate and beautiful tints.

Beauty of Nice. Delicate shade Almond Blossom. White, shaded of the tenderest flesh pink, or daybreak color.

Queen Alexandra. Delicate Crimson King. Brilliant decp carrosy lilac, very showy mine rose

Per plkt.

Empress Augusta Victoria. A beautiful tint of silvery lilac, large
flowers. In separate colors ............ Trial pkt., 10 sts.. \$0.25 flowers. In separate colors ...........

\section{NOVELTY STOCK. GIANT ABUNDANCE}

This is equally valuable for summer or winter flowering. The central stem divides into 12 to 15 lateral branches which each produce from 15 to 20 side shoots forming a veritable pyramid of large fragrant blossoms. The color is an exquisite shade of carmine rose, and the whole plant presents a picture of floral perfection. Ht, 18 to 20 inches

Trial pkt., 10 cts.

\section{SILENE}

\section{CATCHFLY}

Armeria. Early flowering, showy, hardy annual, bearing in profusion, hcads of rose-pink lowers. Ht. 1 foot

Pendula. Massed in beds on rockwork, or for borders these precty Alowers are extremely cfiective. Ht., 9 inches.

Pendula alba. Pure white, or rose.......1/4 oz., $15 \mathrm{cts..} 05$

Mixed. all shades ..................1/4 oz., $10 \mathrm{cts.} \mathrm{.} \mathrm{.} 55$ 


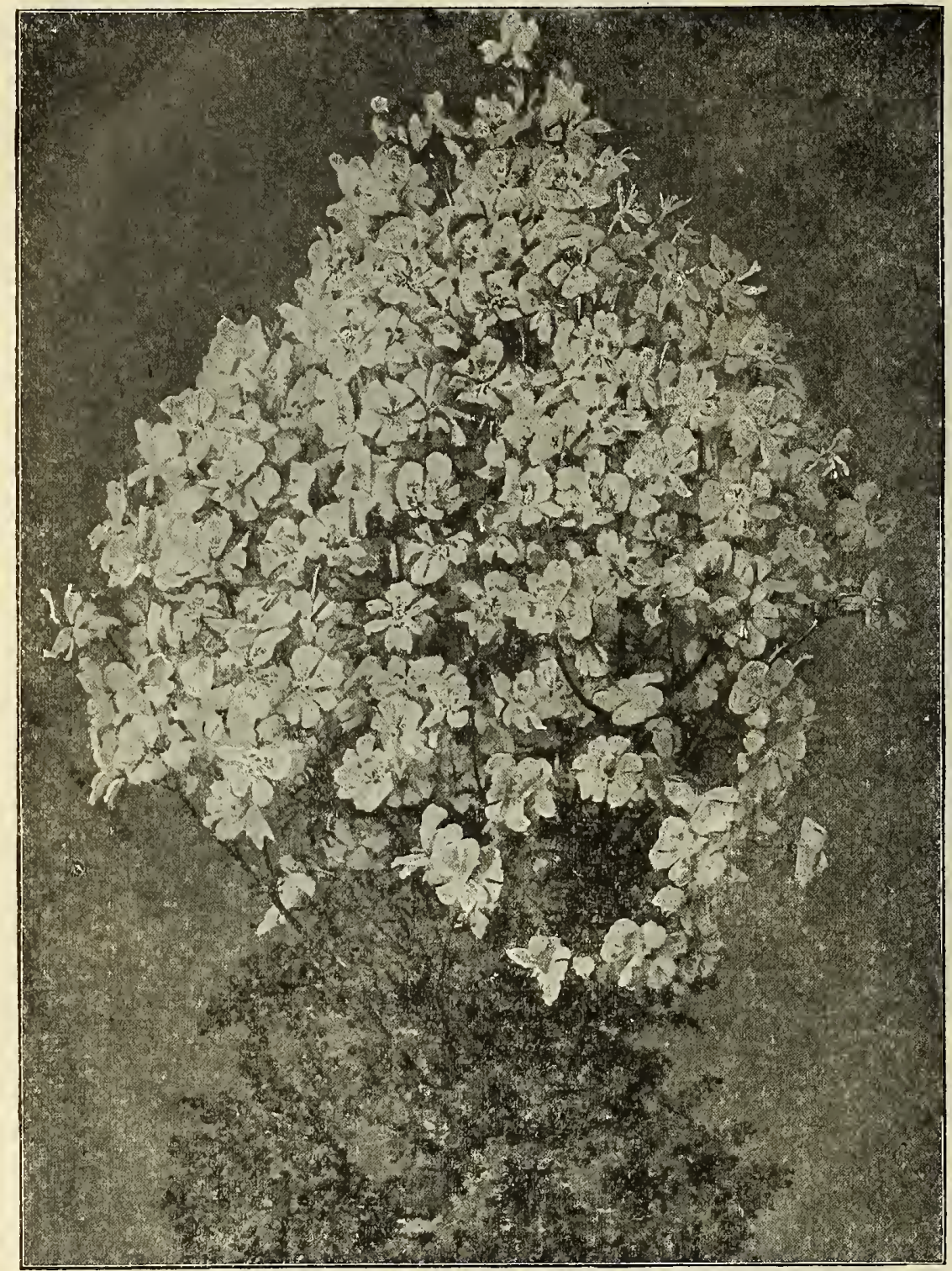

\section{SHIZANTHUS}

\section{BUTTERFLY_FLOWER}

These form one of the most charming flowers for the garden in summer and for the house in winter. Sow for early bloom in the house about February. Sown outdoors they bloom all through July up to early frosts. All Shizanthus have beautiful laciniated blossoms with contrasting colored lips. The wealth of tints represented in them is astonishing. They are of easiest culture preferring light soil and a sunny exposure. Ht. 2 to $2 \frac{1}{2}$ feet.

Grahami. Deep rose with orange lip speckled brown.

Per pkt.

Retusus albus. White and gold $1 / 4$ oz., 15 cts.; oz., 50 cts.. $\$ 0.05$

Retusus. Red and yellow.

Wisetonensis. Enormous range of charming colors, cream white

with yellow centre to carmine rose with brown centre.

Mixed

Trial pkt., 10 cts.

\section{NOVELTY SHIZANTHUS}

Bridal Veil. Pure white (Rare)........ Trial pkt., 10 cts.

\section{STEVIA}

Serrata. Free-blooming plants, bearing a multitude of fragrant pure white flowers; suitable for summer or winter blooming largely used for cutting
Verbena Giant Pure White

Auricula Eyed

All colors mixed Striped Sorts

\section{TORENIA Half Hardy}

Very beautiful for pots, beds, or hanging baskets. Flower is like a small Petunia and puts one in mind of a musk plant with violet and white flowers. Exceedingly ornamental. Ht. 10 inches. Needs a warm sunny place.

Bailloni. Golden yellow with deep red throat. Very charming. Per pkt., 25 cts.

Fournieri grandifora. Sky blue with violet yellow throat. Per pkt., 25 cts.

Coelestini. Delicate pale azure. Per pkt., 5 cts.

White Wings. Pure white, rose throat, exquisite. Per pkt., 5 cts.

Trial packet, $10 \mathrm{cts}$.

SANTIVALIA. Charming annual of spreading habit, especially suited for small beds, edgings, rockwork, and hanging baskets or window boxes, etc.. Bears double and semidouble, ranunculus like flowers of golden double, ranunculus like flowers of golden Succeeds best in light sandy soil. Ht. 6 Succeeds best in light sandy soil.
inches. $1 / 4 \mathrm{oz} ., 30 \mathrm{cts}$; pkt., $10 \mathrm{cts}$.

\section{WALLFLOWERS}

These can be treated as annuals, and if wanted for earliest bloom in the garden should be sown in the house early in season. Sown out-of-doors later they bloom from July to frosts. They are one of our most delightful frosts. They are one of our most delightful exquisitely fragrant and when cut last a long exquisitely fragrant and when cut last a long
time in water. They love a warm, sunny spot in the garden.

\section{SINGLE ANNUAL}

Early Parisian. Brilliant golden, shaded orange red.

Primrose. Soft primrose tint.

Bloodred.

Mixed

$1 / 4$ oz., 50 cts.; pkt., 10 cts.

\section{WHITLAVIA}

Very showy annuals, with bellshaped flowers, borne in profusion on compact plants. Ht. 12 inches.

Grandiflora. Blue. Oz., 25 cts.; pkt., 5 cts.

Grandifora. Blue with white throat. Oz., 25 cts.; pkt., 5 cts.

\section{VERBENAS}

MAMMOTH STRAINS

These are very easily" raised from seed. They produce large trusses of brilliantly colored flowers, especially fine for beds. Much used for early pot plants.

\section{VINCA (Madigascar Periwinkle, or Old Maid)}

Ornamental free-blooming plants and one of the most satisfactory flowering bedding plants we have. It is best to start the seed early indoors, but they begin blooming in August from seed sown out of doors in May, or as soon as the ground is warm, continuing until frost; fine cut flower, every bud opening when placed in water. 2 feet.

Per Pkt.

$\ldots \ldots \$ 0.10$

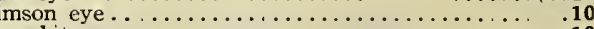
Alba Pura. Pure white $\ldots \ldots \ldots \ldots \ldots \ldots \ldots \ldots \ldots \ldots \ldots \ldots \ldots . .10$

\section{VIRGINIAN STOCKS}

One of the prettiest, most useful annuals to grow. The bright and brilliant colors make a great display between spring and summer flowers, producing a singularly happy effect wherever grown. Ht. 6 inches. If the seed is simply scattered on the ground, in the crevices of stones, rocks, or old walls the darling flowers appear with incredible swiftness. Colors are mauve, rosy purple, crimson, and 


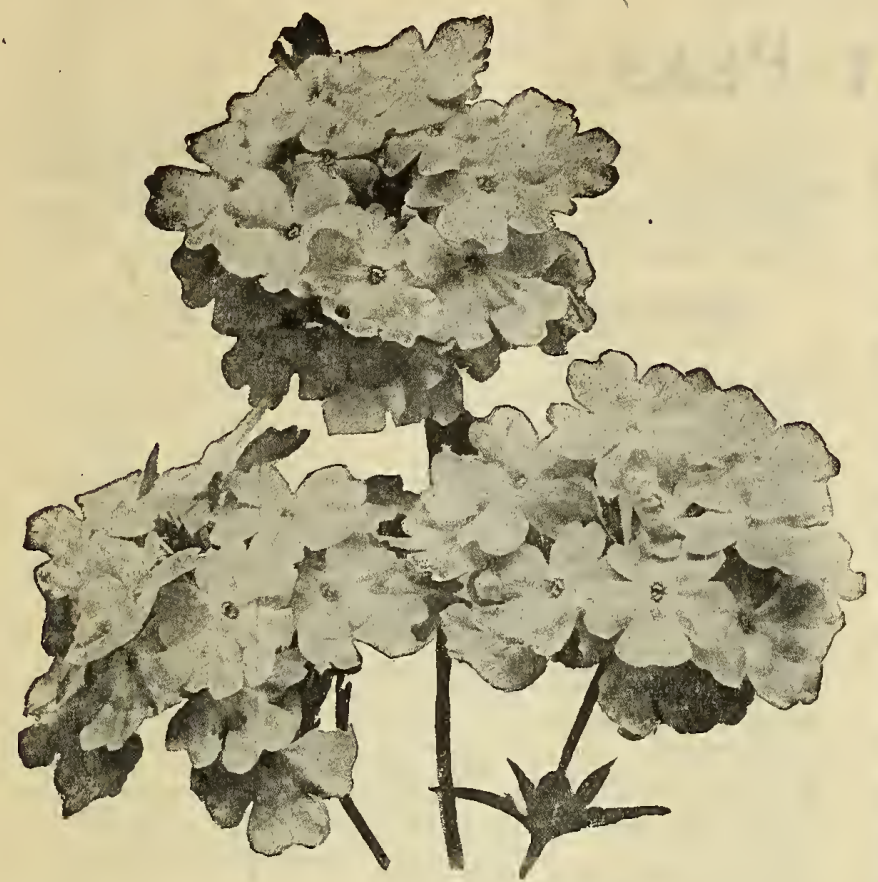

Verbena

\section{ZINNIAS}

An invaluable plant for the garden. One of the most grateful showy garden annuals. Have you ever seen a row of them standing like a regiment of soldiers in bright uniforms, white, sulphur, scarlet crimson, all the colors of the rainbow. If not, you have missed one of the most brilliant displays. There are so many colors and sizes of them quite bewildering but all are magnificent in bloom. And they are so modest. requiring literally no care above a fairly good soil and a good supply of ivater especially at blooming time. Sown in succession they keep up a ivater especially at blooming time. Sown in succession they keep up a
continuous display of beauty throughout summer. The tones of colors are as pure and elegant as seen in Begonias.

\section{ZINNIAS ELEGANS}

\section{SINGLE FLOWERING}

White

Kellow
Rose

Flesh Color

Any color. $1 / 4$ oz., $30 \mathrm{cts.;} \mathrm{pkts.,5}$ cts.

Mixed. 1/4 oz.. su crs.; pkts., 5 cts.

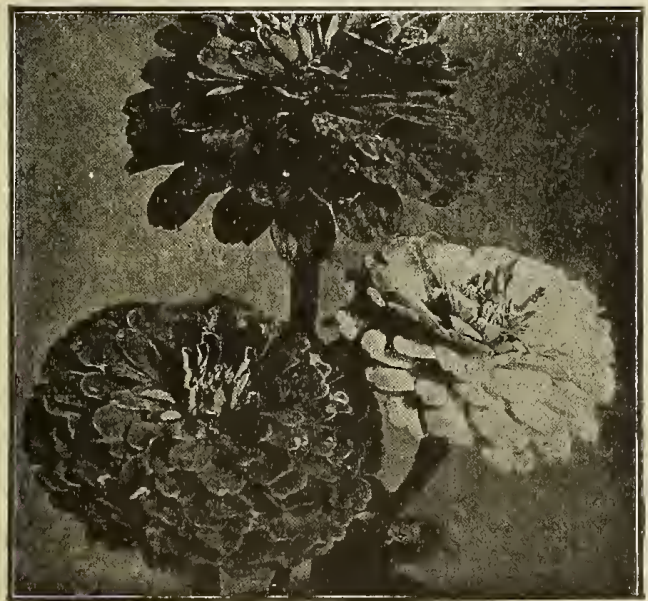

Double Zinnias

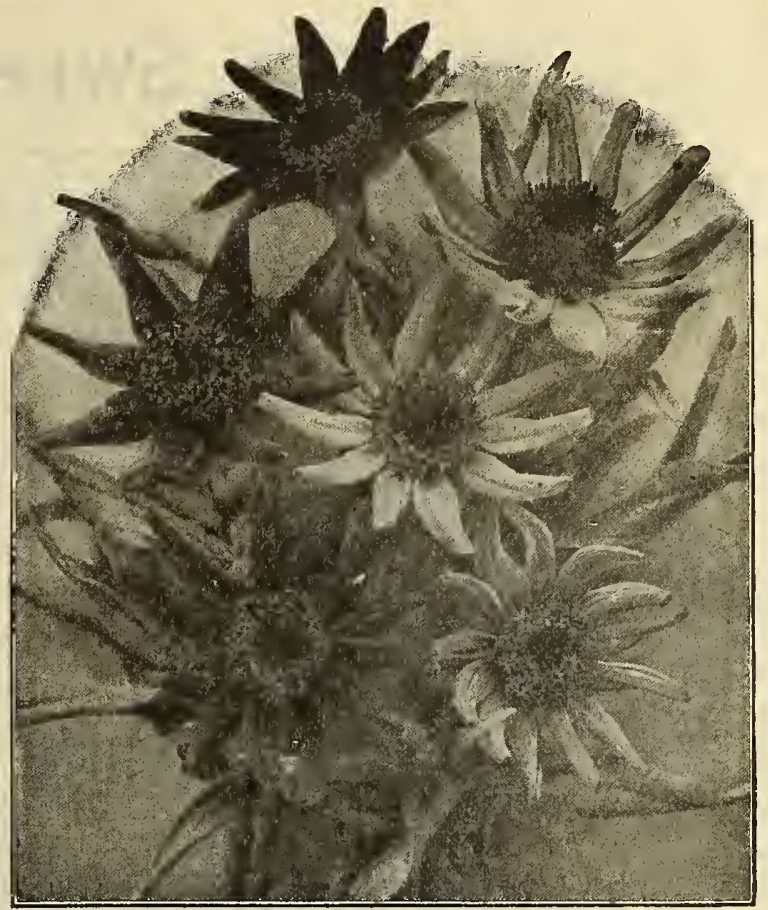

Zinnia-Haageana Stellata

\section{NEW ZINNIA HAAGEANA STELLATA HYBRID}

A splendid novelty in this favorite flower. Pe: pkt. Pe:
are as
ossoms picture shows, star formed, twisted downward. The single blossoms are large and the colors range through primrose, golden yellow, orange, light red, dark blood-red, yellow with red points, red with yellow points, in short, the richest tints, making a group of these flowers a points, in short, the richest tints, making a group of these flowers
brilliant sight and ornament to any garden. Ht. 10 to 12 inches. Trial pkt., 10 cts.

\section{ZINNIA HAAGEANA SULPHUREA DOUBLE FLOWERED}

A new variety of the dwarf spreading Zinnia of Mexico. Ht. 15 to 18 inches. The double flowers range in shades from sulphur to gol den orange. Very showy in beds or borders.....1/4 oz., 40 cts...

ZINNIA DOUBLE TALL Ht. 2 feet

$\begin{array}{lll}\text { Rose } & \text { White } & \text { Crimson } \\ \text { Golden yellow } & \text { Scarlet } & \text { Sulphur } \\ \text { Lilac } & \text { Striped } & \text { Flesh color }\end{array}$

Any color separate.........1/4 oz., 30 cts.; oz., 60 cts... . 0 Mixed strain. ............. $1 / 4$ oz., 30 cts.; oz., 60 cts... .05

\section{ZINNIA ELEGANS, DOUBLE DWARF}

Very double flowers of intense brilliancy. Ht. $1 \frac{1}{2}$ feet

$\begin{array}{lll}\text { Rose } & \text { Crimson } & \text { Flesh pink } \\ \text { Salmon pink } & \text { Orange or gold } & \text { Sulphur }\end{array}$ White

Any color separate or mixed. . ... . 1/4 oz., 30 cts.; oz., 65 cts.

.05

\section{ZINNIAS LILLIPUT OR TOM THUMB}

A charming Dwarf sort, forming compact bushes one foot high literally smothered in the brilliant flower heads.
Scarlet Gem
Golden Gem
Lilac Gem

White Gem

Orange Gem

Lilac Gem

.10

\section{ZINNIA CURLED AND CRESTED}

Large double flowers curiously twisted and curled like Cactus Dahlias, many colors mixed . . . . . . . . . . . . . . . . . . . 


\section{SWEET PEAS}

Truly the poor man's orchid. They grow so easy and repay so grandly. No garden is a Garden that does not contain a row of these heavenly blossoms. The list we submit is carefully selected from out a bewildering array of all sorts and tints offered. Often the mere form of a petal is enough to create out of it a "new variety." The slightest variation in tint will become a new named sort. We give the colors separate to facilitate

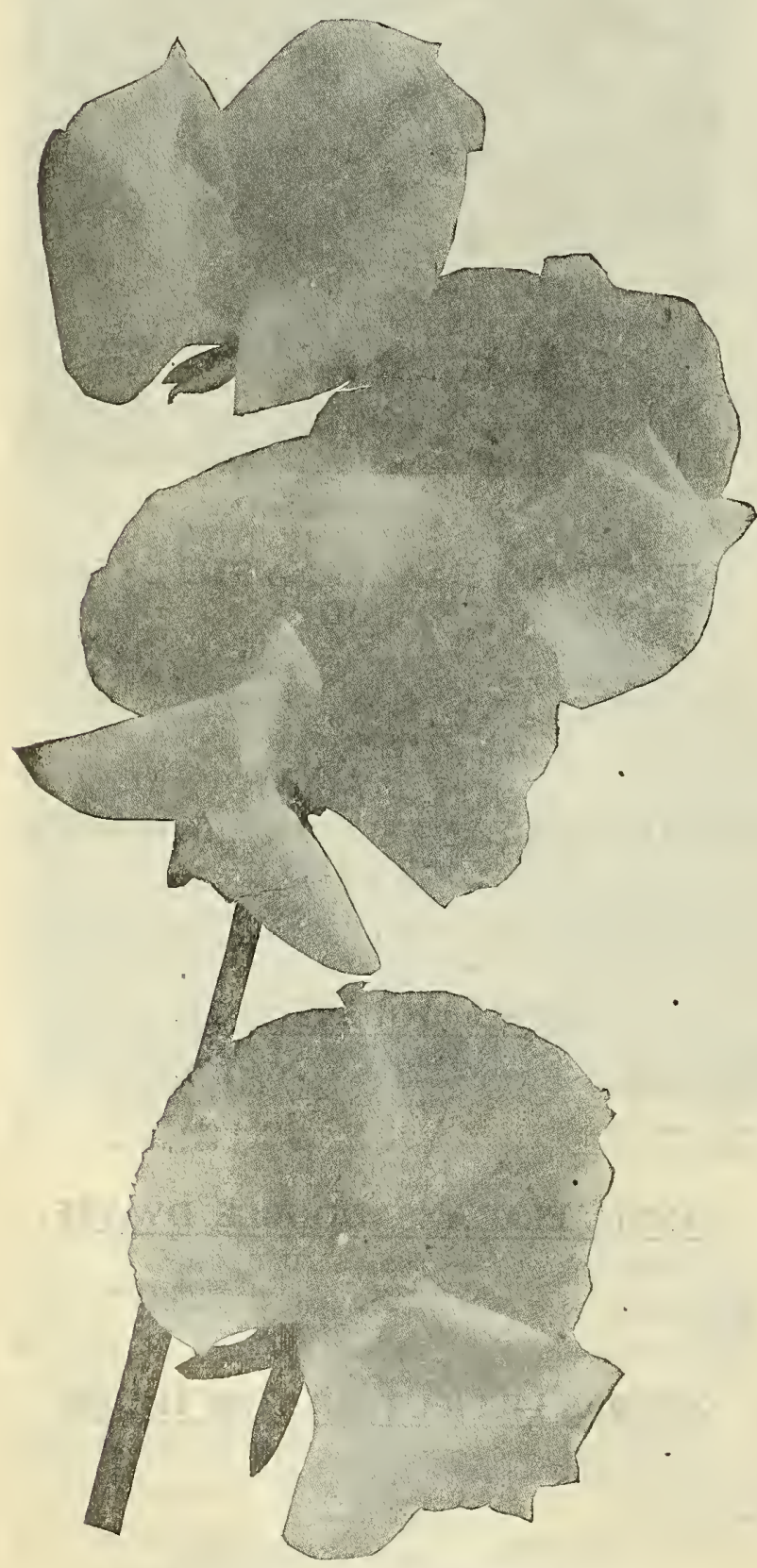

Spencer Type Sweet Peas selection, many preferring distinct color schemes in planting Sweet Peas Order early and sow early. The best time is as soon as all danger of frost is past.

Sweet pea seed is very scarce for the spring of 1916. Send early orders to avoid disappointment.

Packets contain 40 to 50 seeds.

\section{SPENCER TYPES OF SWEET PEAS}

Apple Blossom Spencer. Beautiful white and rose tints, petals and wings very large,

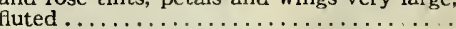

Asta Ohn Spencer. Each stem bears four to five flowers of the most beautiful softest lavender. A gem of sweet peas .........

Aurora Spencer. Cream white ground, mottled with rich orange salmon .........

Beatrice Spencer. A beautiful shade of rose with wide expanded wavy standards and wings $\ldots \ldots \ldots \ldots \ldots \ldots \ldots \ldots \ldots$

Blanche Ferry Spencer. Standards bright rose, wings bluish white, often flushed pink.

Clara Curtis Spencer. A magnificent

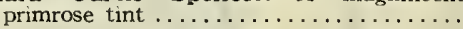

Countess Spencer (True type). Softest rose pink, to deeper rose. Flowers very large, borne three -and four on long, stiff stems . . . . . . . . . . . . . . . . . . . . . .

Dainty Spencer. Pure white with rose pink margin. Very fine ............

Etta Dyke Spencer. The most magnificent largest pure white Spencer ...........

Flora Norton Spencer. The richest purest lavender tint imaginable ..............

Florence Morse Spencer. Delicate blush with rose pink margin. Very large wide open flowers with long stems, generally four flowers to the stem. Magnificent ....

George Herbert Spencer. A magnificent light rose carmine ...............

Helen Lewis Spencer. Intense rich orange salmon. Very large flowers, beautifully waved . . . . . . . . . . . . . . .

King Edward Spencer. Truly gigantic blossoms of richest dazzling crimson scarlet. . . . . . . . . . . . . . . . .

Irish Belle or Dream. Color a lovely grayish lilac flushed with rose. A magnificent

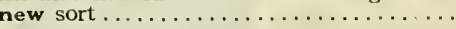

Margaret Atlee Spencer (New). Rosy salmon, shaded buff. A very glorious tint. $1 / 2,02,25$ cents $\ldots \ldots \ldots \ldots \ldots \ldots \ldots \ldots \ldots$.

Marie Corelli Spencer. Wings pure rich rosy crimson; standards a cerise red. Like a huge butterfly of brilliant coloring .......

Mary Garden Spencer (New). A most beautiful rich creamy pink, inclined to duplex. Bold large flowers, immense duplex. Bold large fowers, immense

Martha Washington Spencer. Pure white, edged with deep pure rose.............

Mrs. Routzhahn Spencer. A very showy sort, apricot pink and primrose. Enormous flowers. One of the best.............

Othello Spencer a beautifully large deeply waved flower of deep maroon ...........

Pearl Gray Spencer. The fascinating color is light dove or pearl gray, contrasting exquisitely with the deep scarlet rose and blue tones. $1 / 2 \mathrm{oz}, 25$ cents...............

Primrose Spencer. Clear primrose......

Senator Spencer. On light heliotrope ground appear flakes of deep claret and chocolate. Immense flowers, prolific bloomer ......................

White Spencer (Snowclad). Profusion of large richly fluted and waved flowers three and four to the stem ...............

The Finest Mixture of Spencer type Sweet

Peas. All sorts, all colors represented. Lb. 2.50 whole list per large pkt. 15c.; per oz. 40c., small pkt. 5c.
Price on 
SWEET PEAS-Continued

PURE WHITE

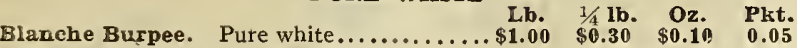

Emily Henderson. Profuse flowering, very

early, large flowers............... $\mathbf{1 . 0 0}$

Mont Blanc, or Florence Denzer. The $\begin{array}{llllll}\text { earliest white. A pure paper white........ } & \mathbf{1 . 5 0} & . \mathbf{4 0} & \mathbf{. 1 5} & .10\end{array}$

Nora Unwin. Very large, beautifully waved

$\begin{array}{lllll}\text { flowers, generally three borne on one stem. } & \\ \text { Very bold wavy standards................ } & 1.50 & .40 & .15 & .10\end{array}$

\section{BLUSHROSE}

Countess of Latham ................

Gladys Unwin. One of the finest of the Unwin type with striking upright crinkled and waved standards, broad wings. The

most exquisite pale rose............. 1.50

Lavely. Soft shell pink. Very refined flower $\mathbf{1 . 0 0}$

Prima Donna. Large flowers of very soft

light rose........................ 1.25

Queen of Spain. Peach blossom pink.

Very large flower $\ldots \ldots \ldots \ldots \ldots \ldots \ldots, 2.00$

\section{DEEP ROSE AND CARMINE ROSE}

Bolton's Pink. A very brilliant rose....... 2.00 $\quad .50$

Janet Scott. A deep very rich rose. Very

large sized wings, enormous flower........ 2.25

Prince of Wales. Deep clear rose pink a

unique shade splendid in artificial light..... 1.27

Rose du Barri. This is a marvelously beau-

tiful type. Flowers are a deep rose color

overlaid with a lovely shade of terra cotta.

Unsurpassed for decorations and artificial

light.............................

\section{VARIEGATED AND MARGINED}

Blanche Ferry. Extra early. The very finest rose and white variety. Very early

flowering............................. 1

petals, beautifully flasked with orange sal-

petals, Veatremely showy with orange sal-

America. White ground striped crimson

red. Fine....................... 1.00

Dainty. Large beautifully formed flowers,

pure white with rose pink margin. A
charming contrast.................... 1.00

Hester. White ground with deep blue stripes giving a unique mottled appearance.

Very rich flowering...................... 1.25

Jessie Cuthbertson. Primrose yellow to

light cream with rich dark rose flakes over-

laying petals......................... 1.25

Prince Olaf. Immense bold flowers, of ten

four to a stem, striped and mottled brilliant

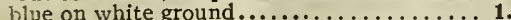

\section{CRIMSON AND SCARLET}

King Edward VII (Firefly). The most Lb. $3 / 4$ lb. . Oz. Tht:

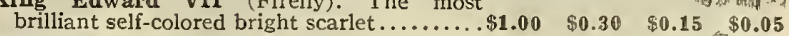

Millie Maslin. Crimson red, one of the

$\begin{array}{lllll}\text { richest, dazzling shades................. } & 2.00 & .60 & .20 & .05\end{array}$

Queen Alexandra. Brilliant rosy scarlet of

intense coloring. A very large bold flower.

$\begin{array}{lllll}\text { Not affected by hot sunshine } \ldots \ldots \ldots \ldots \ldots & \mathbf{1 . 2 5} & .40 & \mathbf{. 1 5} & .05\end{array}$

Salopian. A magnificent showy clear scar-

let, sunproof ........................ $1.25 \quad .40 \quad .15 \quad .05$

\section{YELLOW, SALMON AND PRIMROSE}

Evelyn Byatt. Rich orange salmon. Very large flower. Magnificent............... $1.50 \quad .50 \quad .20 \quad$\begin{tabular}{lll}
.05 \\
\hline
\end{tabular}

Golden Rose. Very exquisite light rose

yellow. Unique...................... $2.00 \quad .60 \quad .20 \quad .05$

Mrs. Eckford (Golden Gleam). Light $\begin{array}{llllll}\text { primrose self-seeded.................... } & \mathbf{1 . 7 5} & .60 & .20 & .10\end{array}$

Early Sunbeams. Rich primrose tint.

$\begin{array}{llllll}\text { Very early, free flowering } \ldots \ldots \ldots \ldots \ldots \ldots \ldots & 2.00 & .50 & .20 & .05\end{array}$

Hon. Mrs. Kenyon. Bold, very large

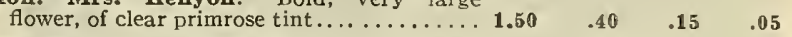

Miss Willmott. Orange pink, graceful flower,

$\begin{array}{lllll}\text { magnificent for artificial light } \ldots \ldots \ldots \ldots \ldots & 1.25 & .40 & .15 & .05\end{array}$

Wm. Sim A magnificent pure salmon

tint............................. $1.25 \quad .40 \quad .15$

BERGER'S CHOICEST EXCELSIOR MIX.

$\begin{array}{lllll}\text { TURE } \ldots \ldots \ldots \ldots \ldots \ldots \ldots \ldots \ldots \ldots \ldots & .75 & .25 & .10\end{array}$

\section{CERISE}

Chrissy Unwin. Large wavy petals.

Flowers a rich deep cherry .............. 2.00 $\quad .60 \quad .20 \quad .10$

Coccinea. A magnificent self color of most

$\begin{array}{lllll}\text { brilliant cherry .......................... } & 2.00 & .60 & .20 & .10\end{array}$

\section{LAVENDER, BLUE AND PURPLE}

Brilliant Blue. The richest most showy

Brilliant Blue. The richest most showy
blue of clear tint............................ $1.00 \quad .30$

$\begin{array}{lllll}\text { Captain of the Blues. Clear fine purple } \ldots & 1.00 & .25 & .15 & .05\end{array}$

Countess of Cadogan. Reddish mauvé standards, wings bluish violet. A brilliant

Countess of Radnor. Lovely clear lav-

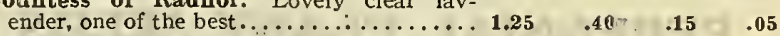

Frank Dolby (Unwin type). Bold wavy $\begin{array}{llllll}\text { standards and wide spreading wings, the } & & & & \\ \text { whole beautif ully waved and fluted } \ldots . . . . . & \mathbf{3 . 5 0} & 1.00 & .35 & \mathbf{. 1 0}\end{array}$

$\begin{array}{lllll}\text { Flora Norton. Beautiful clear light blue.... } 1.25 & .40 & .15 & .05\end{array}$

Duke of Clarence Westminster. Rosy

$\begin{array}{lllll}\text { claret and violet, Very beautiful........... } & 1.25 & .40 & .15 & .05\end{array}$

Navy Blue. Large flowers of deepest violet

purple,......................... $1.25 \quad .40 \quad .15$

\section{FUCHSIA}

These very beautiful plants should be better known. It is to be re gretted that they are as yet almost outside the knowledge of flower lovers. The drooping blossoms of brightest tints are an ornament to any, place whether in the garden in summer, on the veranda, in bedding, or in the house in winter. The seed is easy to raise. Seedlings bloom the first year.

Single Sorts. Trial plst., 10 ets.. $\$ 0.25$ Beautiful Double Varieties................. Trial plkt., 10 cts... .25

$\begin{array}{ll}\text { Giant Pure White } & \text { Giant Cærulea (Sky blue) } \\ \text { Giant Rose Queen } & \text { Giant Salmon King }\end{array}$ Giant Rose Queen

Trial plt., 10 ets.; large pkt., 40 cts...\$0.25

Collection of 5 colors, $\$ 1.00$.

Primula Kewensis (Giant Buttercup Primula). A very robust grower with bright graceful and numerous erect flowerscapes, 12 to 18 inches high, producing flowers in whorls at intervals along the whole length of stem. Flowers are a clear buttercup yellow, slender, tubular, I-inch in diameter, very attractive and unique.

Primula Malacoides (Giant Baby Primrose). Flowers measure $1 / 2$ to $3 / 4$ of an inch across; delicate lavender color; grow in whorls $1 / 2$ to $3 / 4$ of an inch across; delicate lavender color; grow in whorls around branching stems which are very strong and gracef ul. Bloom
in four months from seed. Sowing in August furnishes a rich display all through winter.

Trial plst., 10 cts.; large plst., 50 cts... .25

Frimula Malacoldes Alba. A new white form of the above. Very chaste and most beautiful..............Large pkt., 50 cts...

Primula Obconica Gigantea. Charming species, very floriferous -in separate colors white, rose, blood red, lilac rose.

Large pkt., 25 cts... . .10

\section{GERANIUM}

Apple Scented Geranium. Very fragrant foliage, smail light lavender flowers. 50 seeds, 10 cts.

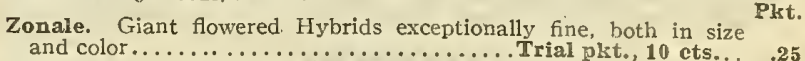

Ivy Leaved. Fine glossy green foliage. Immense trusses of brightly colored rosy flowers. Of the brightest effect in garden vases, window boxes, in pots, etc........... Trial plst., 10 ets..

Pelargonium Geranium (Lady Washington). Fancy sorts of the finest French collection. Io seeds, 10 ets.; 25 seeds, 20 cts.

GREVILLEA ROBUSTA (Australian Silk Oak), A very dainty plant with fernlike glossy foliage. Especially useful for centrepieces in garden vases, and as centre in beds of low growing flowers such as Verbenas and annual Phloxes. Most ornamental in the house for window garden................. Trial pkt., 5 cts... 


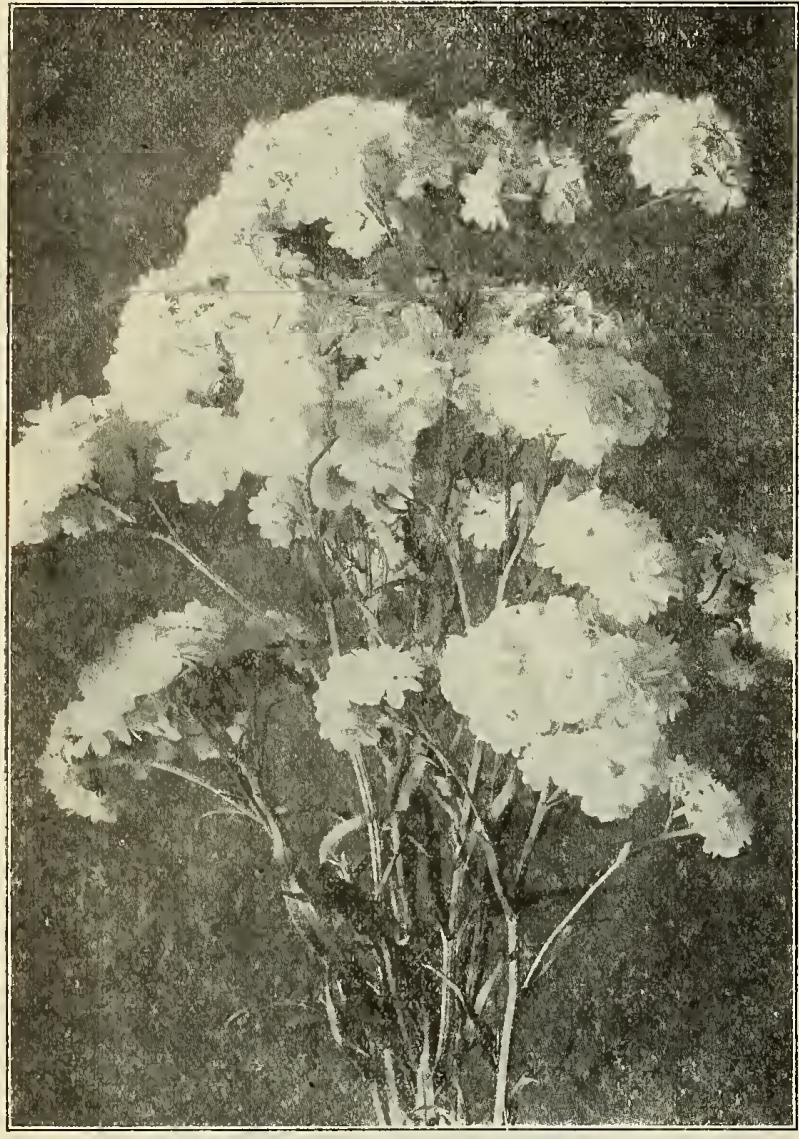

Achillea "The Pearl"

\section{PERENNIAL PLANT SEEDS} ACHILLEA. (MILLFOIL UK YARROW)

Ptarmica, flore pleno. The Pearl-I mproved sort, bearing masses of double white flowers, splendid for cutting. Ht. 2 feet

ACANTHUS LATIFOLIUS (Bear's Breech). Stately, hardy plants with handsome foliage, producing spikes 5 feet high of deli-
cate rose and white fowers. Excellent for specimens on lawn or in cate rose and white flowers. Excellent for specimens on lawn or in
border. Flowers July and August. . . . $10 \ldots \ldots$. Oz., 50 cts. .\$0.10

\section{ACONITUM, MONKSHOOD}

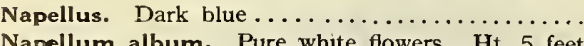

Aureum (Novelty). Giant yellow Monkshood, soft yellow flow ers in July and August.............. Trial pkt., 10 cts.

ADENOPHORA POTANINI (Giant Bellflower). Beautiful hardy perennial with numerous large bell-like flowers, drooping habit. Color a delicate azure. Ht. 18 inches. July to September

ADONIS VERNALIS. Adonis's flower of spring. The huge buttercup like flowers appear when the snow is barely off the ground. One of the finest spring flowering perennials. Ht. 9 inch es.

$$
1 / 4 \text { oz., } 25 \text { cts. }
$$

AGATHEA COELESTIS (Blue Marguerite). Flowers a rich blue with golden centre. Ht. 18 inches. ........1/4 oz., 25 cts.. ALSTROEMERIA (Peruvian Lily). Beautiful lily-like flowers in great clusters on slender stems. Colors range from primrose yellow to deep gold and orange red. Splendid for cutting. Will only germinate in cool, damp weather. Sow 18 inches apart. Blooms June to August. Ht. 3 feet. Mixed colors ...1/4 oz., 50 cts..

\section{ALYSSUM}

Saxatile compactum (Gold Dust). Produces billory masses of bright yellow flowers, throughout the whole season. Spreading habit. Ht. 6 inches......... Oz., 75 cts.; 1/4 oz., 20 cts...

Saxatile Silver Queen. The flowers are a lovely primrose tint. Ht. 9 inches ................... Trial pkt. 10 cts...

ANCHUSA BARRELIERI. Freeblooming, forget-me-not-like flowers. Ht. 18 inches. July and August. . . 1/4 oz., 25 cts. .

Anchusa Italica Dropmore. Handsome bushes covered with brilliant Gentian blue flowers, during June to August. Ht. 4 to 5 feet. ....... $1 / 4$ oz., 75 cts.
ANEMONE SYLVESTRIS (Windflower) Per Ph flowers especially fine for naturalizing ANTHERICUM LILIAGO. St. Bernard's Lily. A magnificent perennial bearing spikes of pure white lily-like flowers, during May and June. Excellent for cutting and very fragrant. Ht. 2 feet. ..................... oz., 50 cts...

Liliastrum (St Bruno's Lily). A truly charming plant with long narrow grass-like foliage and white lily-like flowers with a green
blotch on each petal. Ht. 2 feet......... oz., 50 cts....

\section{ANTIRRHINUM}

\section{SNAPDRAGON}

These beautiful flowers are coming into their own, as they were bound to do, sooner or later. There are no other flowers which give such a lavish return for so little trouble. Any one can grow them, you need no greenhouse, unless it be, to raise a few plants for very early flowering. Seed can be sown at once in the open ground.

Buy only the very best strain of seed. It were time and trouble thrown away to buy any seed but the very best. To give the very best color effect, buy and grow the plants in separate colors Mixed colors are kaleidoscopic and please some, but you cannot produce color harmony. real floral music, unless you have the pure color tones to play with.

\section{ANTIRRHINUM MAJUS}

These comprise the tallest growing varieties. Plants attain a height of 2 to $2 \frac{1}{2}$ feet, branching habit, giant flowers, very floriferous.

Brilliant. Scarlet yellow and white.

Fairy Queen. Golden orange with white throat.

Galathea. Crimson, white throat.

Luteum. Sulphur yellow.

Striped sorts.

Delicata. Bright rose.

Firefly. Orange scarlet with white throat. New very striking.

Coral Red. New color, delicaie light scarlet with white throat.

Nigrescens. Dark purple.

Queen Victoria. Pure white.

Any of the above listed sorts ... Oz., $\$ 1.00 ; 1 / 4$ oz., .30; pkt. .10 The ten sorts in a collection of ten pkts. $75 \mathrm{cts}$

Mixed .................... .60; $1 / 4$ oz., .20; pkt. .05

\section{ANTIRRHINLIM MAJUS NANUM}

These attain a height of 18 inches the flowers are immense and the whole
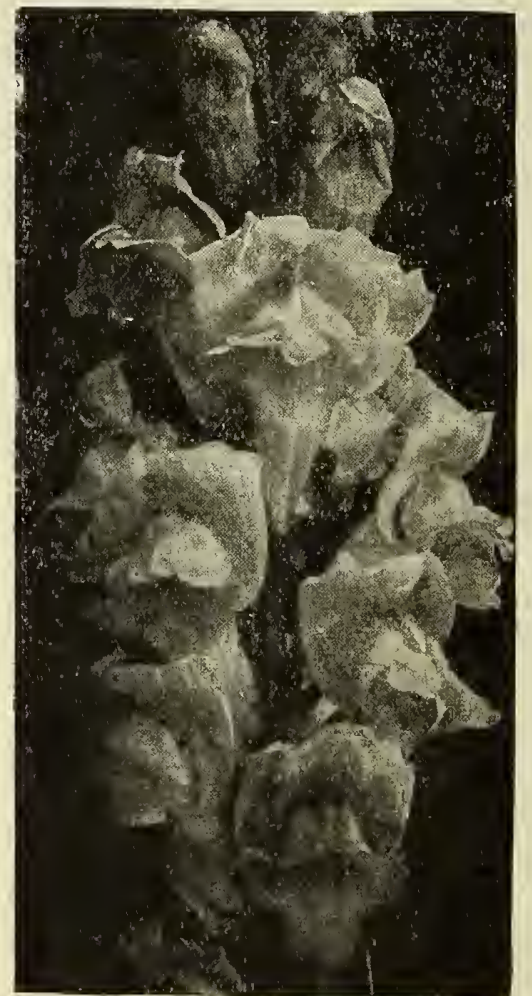

is of dazzling beauty. Very effective if planted in the foreground of taller sorts.

Buff Queen. Salmon buff with yellow centre.

Golden Queen. Giant flowering golden yel. low.

Montblanc. The largest flowering white.

Prince Chamois (New). Gold chamois.

Daphne. Beautiful deep rose with white throat and lip.

Mauve Queen. New art shade of rosy heliotrope.

Daybreak (Aurora). Magnificent vermilion deep scarlet with white throat.

The Bride. White, turning into rose. Most beautiful.

Black Prince. Black red with white throat. New, very striking.

Striatum. Striped.

Mixed. $1 / 4$ oz., 30 cts.; pkt., 5 cts. Any of t.l above sorts listed $1 / 4$ oz., 50 cts. : pkt., 10 cts. cts.; pkt., 10 cts. in collection of ten Antirrhinum (Snapdragon) packets 75 cts. 


\section{DWARF BEDDING GIANT FLOWERING}

\section{ANTIRRHINUMS}

These attain only a height of 8 to 9 inches. Unsurpassed in beauty for beds, borders, ribbon effects and for rockwork.

Snowflake. Purest white.

Scarlet Slipper. Dazzling.

Sanguineum. Bloodred.

All colors mixed.

Antique rose. A charming shade.

Golden Shoe. Very rich golden yellow.

Striatum. Striped.

Mixed colors

Any on list.

The six colors in collecticn of six packets 50 cts.

$.1 / 4$ oz., 75 cts... .10

\section{AQUILEGIA COLUMBINE}

If you do not know this splendid and lovely flower the picture will convey to you much less than it would did you have just a passing acquaintance with it. Nothing can excel in tender beauty and charm these plants when in flower, whether as single plants or in beds, in masses or groups. The richri:ss and wealth of coloring is so stunning the eye can hardly take them all in. We list the very best sorts all selected with special care.

Chrysantha. Long spurred, pale yellow, clear tint. Ht. 3 feet.

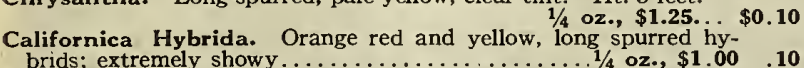

brids; extremely showy ...................1/4 oz., $\$ 1.00$

Rose Queen. Long spurred flowers of the loveliest rose shade with

white centre and long golden anthers. .... Trial pkt., 10 cts... . 25 Carulea (Rocky Mountain Blue). Clear blue with snowy white Corolla. A magnificent sort........... Trial pkt., 10 cts... . 25 Alba. White ......................... 10 One of each of the six colors, 6 packets $85 \mathrm{cts}$.

Mixed shades. Single flowered ............ oz., 40 cts... 10

Double fowering Aquilegias, mixed .......1/4 oz., $\$ 1.00 \ldots .10$

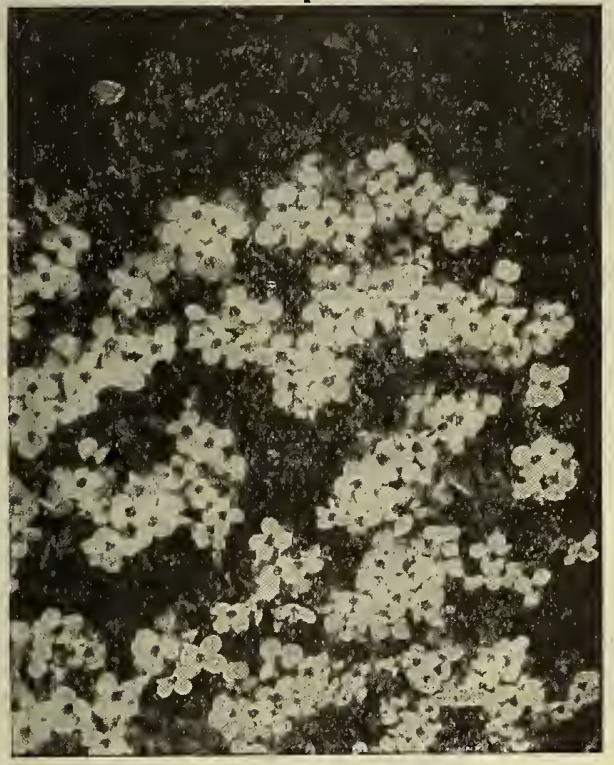

Arabis Alpina

ARABIS ALPINA (Rock Cress). A charming plant for bedding and rockwork. Bears masses of white bloom in early spring. Ht. 10 inches. Plant with golden Alyssum Saxatile and blue Aubretia $\ldots \ldots \ldots \ldots \ldots \ldots \ldots \ldots \ldots \ldots \ldots \ldots \ldots \ldots$. Oz., $_{\mathbf{1}} .00 \ldots$

\section{ASTER MICHAELMAS DAISIES}

These grand Perennials are very easily raised from seed, and if sown very early in spring bloom as a rule the first season. Colors vary in the most beautiful tints.

White Queen. Free flowering, pure white

Nova Anglica. New rose and pink Hybrid

Novae Belgii ranging from lavender to blue and purple.

Separate colors $\ldots \ldots \ldots \ldots \ldots \ldots \ldots \ldots \ldots \ldots 1 / 4$ oz., 75 cts... 10

ARMERIA MARITIMA (Thrift or Seapink). Thrives anywhere.

Fine for cutting. Pretty edging plant with deep rose colored flow-

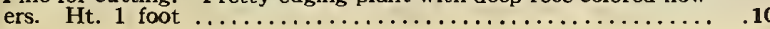

ASCLEPIAS TUBEROSA. Compact umbels of brilliant orange red flowers during July and August. Invaluable for border and shrubbery groups. Ht. 2 feet........... $1 / 8$ oz., 30 cts..

\section{AUBRIETIA \\ FALSE WALL CRESS}

These absolutely first class dwarf perennials will do well anywhere. They are veritable streams of color in their season, mantling the ground and draping rocks with vivid fire of purple, lilac, and lavender, rose and crimson.

Graeca. Lavender to purple

Leichtlini. Rosy carmine to blush

Per pki.

Moerheimi. Glowing rose.

All shades mixed.

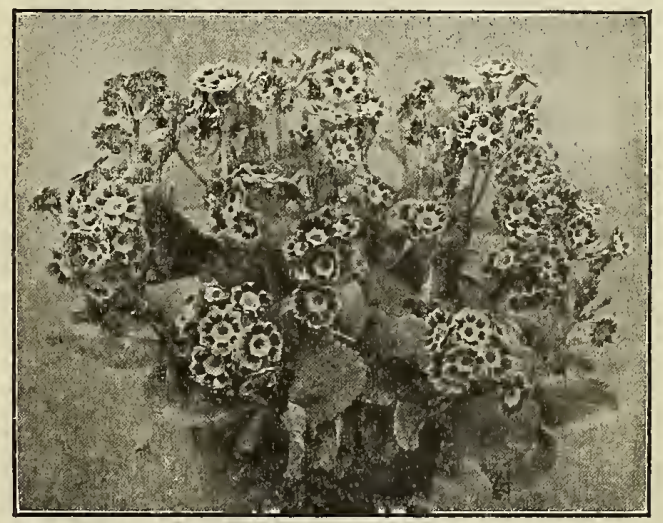

Hardy Auricula

\section{AURICULA $\underset{\text { (Hardy Border }}{\text { Plant) }}$}

Few people seem to realize what a beautiful flower this is. It seems as yet almost a stranger here. The seed germinates best sown in spring in boxes and kept well shaded from the sun.

Mixed in most beautiful shades of fawn, amber, bronze yellow, beauti-

ful assortment. ................. Trial pkt., 10 cts... . 25

BAPTISIA AUSTRALIS (False Indigo). Very sturdy, strong growing plant producing in June and July spikes of pea-shaped bright

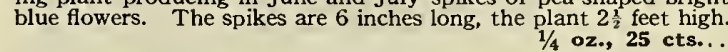

\section{CAMPANULAS-BELLFLOWER}

Carpatica. Blooms all summer. The flowers are clear China blue, large, cupshaped, beautiful for permanent beds or massing on rocks; fine border plant. Ht. 1 foot........ oz., 20 cts... .10

Carpatica alba. White form ...........1/4 oz., $20 \mathrm{cts} . \ldots .10$

Glomerata. Clustered Bellflower. Deep violet blue flowers in dense clusters. July and August. Ht. 18 inches...............

Persicifolia (Peachleaved). The Peachleaved Bellflowers are as hard as nails, never fail to do well everywhere, sending up year after year bigger and better sheaves of bloom. Last a long time when cut. One of the most satisfactory sorts. Spikes of large flowers. Excellent for cutting. Ht. 2 feet.

Blue. . . . . . . . $\ldots \ldots \ldots \ldots \ldots \ldots$ Trial pkt., 10 cts.

White $\ldots \ldots \ldots \ldots \ldots \ldots \ldots$ Trial pkt., 10 cts... Moerheimi a very beautiful form of large, wide open, semidouble flowers borne on long erect stems. . Trial pkt., 10 cts, . . 25

Pyramidalis (Chimney Bellflowers). Noble plants 4 to 5 feet high covered with large handsome salvershaped flowers. Blue flowered........................ oz., 25 cts...\$0.10

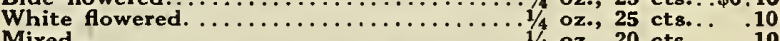

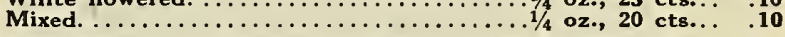

Rotundifolia (Blue English Harebell). A lovely plant. Azure to violet blue flowers, borne on slender stems. Ht. 1 foot.

$1 / 4$ oz., 35 cts. .

Medium (Canterbury Bells). Gracefully erect, leafy stems, bear huge panicles of flowers, which continue to open for a long period of time. Ht. 21/2 feet

Single: Azure, Mauve, Rose, White ................ 40 cts. Double: Lavender, Violet, Rose, White ........ Oz., 40 cts. Single, mixed colors..................... 30 cts. Double, mixed colors .................................. 30 cts.

Calycanthema (Cup and Saucer) (Canterbury Bells). Calyx very large, same color as flowers. Superb and showy. Gorgeous decorative plants in beds or as single specimens in pots. Ht $21 / 2$ feet to 3 feet.

Separate or mixed Lavender, Purple, Rose
10

.10
.10

10

.

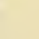




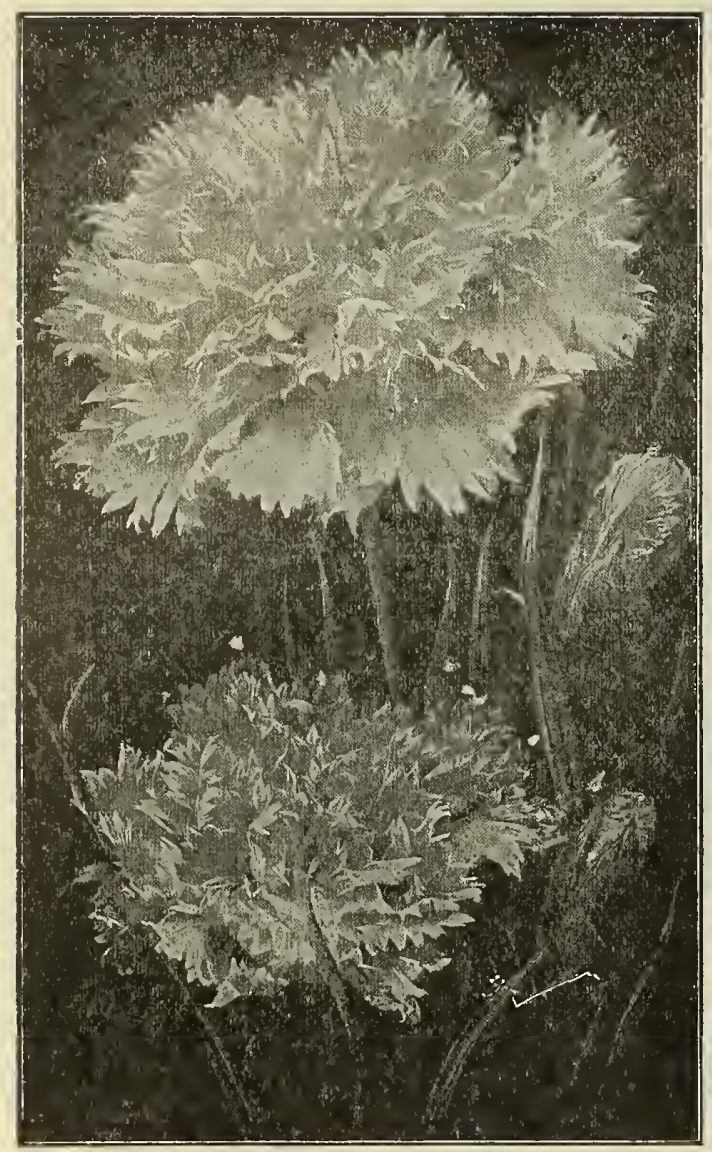

\section{CARNATIONS (MARGUERITE)}

Most fascinating for amateurs to raise these divine flowers from seed Frequently the most beautiful Novelties are found amongst seedlings. Seeds sown in January to March in the house bloom by first of July. In winter the plants must be protected with coarse straw or evergreen branches wher the plants must be protected with coarse straw or evergreen branches fall and bring in the house. The seed we offer will be found to bring 75 to 80 per cent. of doubles.

Giant Imperial Marguerite Improved. Immense double flowers pkt. of greatest range and brilliancy of colors. The best carnation in existence and easiest to raise. Ht. 18 inches. Trial pkt., $10 \mathrm{cts.} . \$ 0.25$ Chabaud's Early Flowering. Will bloom six months from seed. Ht. 18 inches, beautiful delicate tints....... Trial pkt., 10 cts... .25 Grenadin. Very showy, very double flowers. Color a bright scarlet red. Ht., 15 inches............ Trial pkt., 10 cts.. Perpetual or Tree Carnation. Long wiry stems crowded with very large, double flowers of glowing colors... Trial pkt., 10 cts.

Riviera Marguerites or Giants of Nice. A grand new strain originated in the south of France near Nice. Flowers of enormous size, and glorious colors. Bloom in seven months from seed.

Yellow and yellow ground sorts. Trial pkt., 10 cts.. All sorts of Carnations mixed.

Trial pkt., 10 cts.

\section{HARDY PERENNIAL DAISIES}

Most grateful and comforting flowers. When the Mignonette fails and parsley even refuses to grow, one can always turn with pleasant anticipation to these hardy flower friends. They are so easy to grow. Just drop the seeds in any tolerably good soil, accessible to some sunshine and
moisture, then wait and see what they will do." Do not coddle them and moisture, then wait and see what
they will surely surprise you.

\section{SHASTA DAISY}

Does this need any description? Surely you all know its beauty of immense white petals, like rays around a dark or deep yellow disk. The large bushes of this magnificent garden plant are beautiful and useful wherever planted ........1/4 oz., $\$ 1.25 ; 1 / 8$ oz., 75 cts...

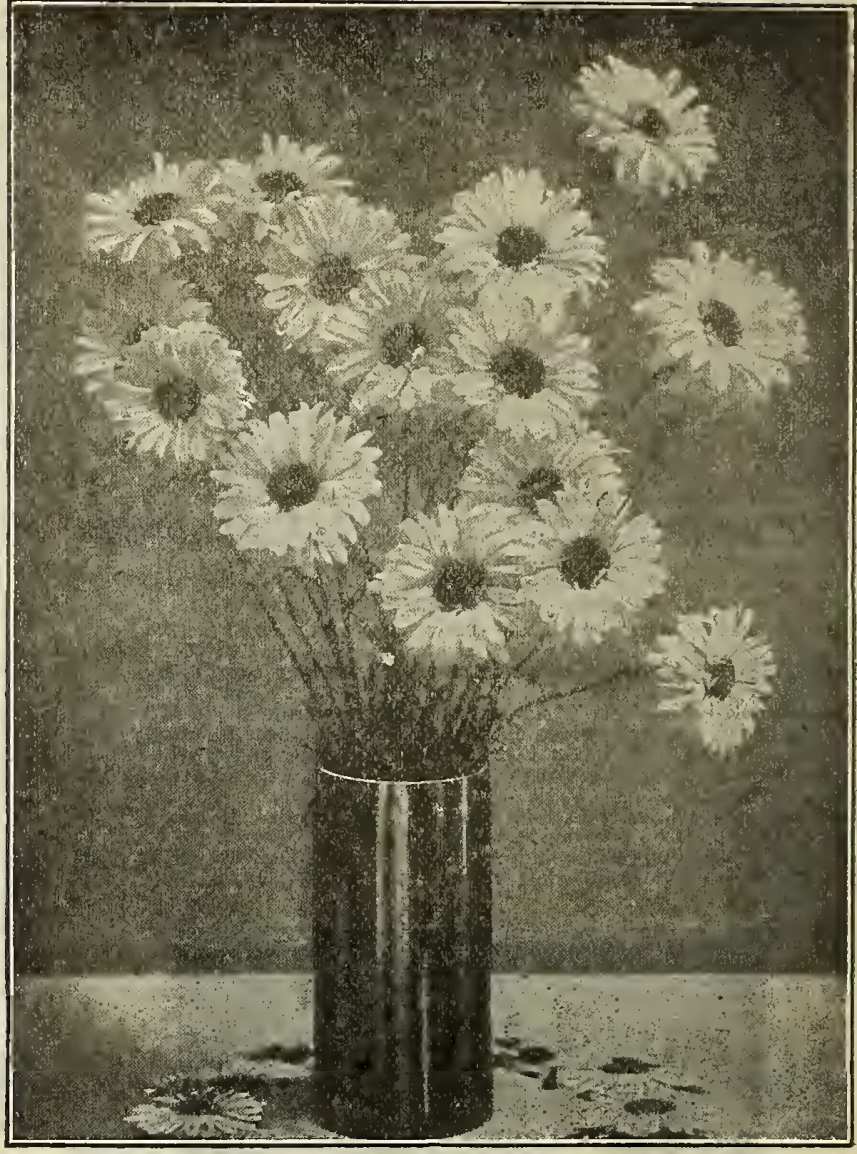

HALF DOUBLE SHASTA DAISIES

This new race has been finally established coming true from seed. pkt. The flowers are all very large, with a very small yellow disk, very long snowy white florets. Many are double, others half double with 4 to 6 rows of ray florets or petals. The stems are very long, wiry, not hollow. For richness of bloom and lasting qualities, no flower surpasses this. It is very hardy and forms large bushes like its pro totype and parent, the single Shasta Daisy. Seed can be sown in open ground in April or May, or indoors, when seedlings can be transplanted ground in April or May, or indoors, when seedlings can be transplanted

\section{DAISIES BELLIS PERENNIS}

If you have no daisies flowering in your garden you miss one of the greatest delights of spring. If you have never raised double daisies from
seed you have never experienced the gardener's delights and disappointseed you have never experienced the gardener's delights and disappointments. Every seed may not prove a swan, but oh, what a joy when some of them blossom forth into true giants of brilliant tints and beauty. $\$ 0.10$ Giant Snowball. ..................... oz., $\$ 1.00 \ldots \$ 0.10$

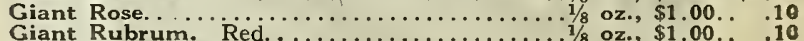
Mixed Giant Daisies ................... oz., $\$ 1.00 . .10$

\section{CALLIOPSIS OR COREOPSIS}

Grandiflora Lanceolata. One of the finest and hardiest. Really indispensable where bright flowers are required. Golden yellow laciniated flowers. For cutting it is unrivalled. Mixed perennial Coreopsis..............

HARDY CANDYTUFT IBERIS

Excellent border and rock plant, thriving in sunshine and shade equally well. The flowers are produced in such abundance that when in bloom the whole plant resembles a drift of snow. Needs

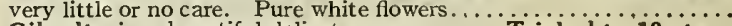
Gibraltarica, beautiful delicate mauve....... Trial pkt.. 10 cts...

\section{DAHLIAS}

Can be treated as an annual. Sow seeds early in the house to obtain bloom in fall. Few flowers have such a grand decorative effect as the dahlia.

Single. Extra choice Giant flowering mixed.....1/4 oz., 20 cts. . \$0.10 Double. Representing the very best sorts... Trial pkt., 10 cts... .25 Cactus Dahlias. Very choicest kinds.......Trial pkt., 10 cts... . .25 


\section{MAMMOTH DAHLIA-NOVELTY}

No Dahlia enthusiast can miss this grand flower in his collection. It leans most towaro the type of the gorgeous new Pæonia Dahlias, as picture shows, although ther will be found flowers with twisted and curled petals showing the strain of the Cactus variety. The dimensions of the flowers which are borne on very long stiff stems, are from 7 to 8 inches across, and range in color through a bewildering variety from pure white throug all lilac and mauve tints. From delicate blush through rose, crimson to deep red and maroon. Yellow, prim rose, orange, bronze, all are found. A group of these Dahlias are a glory to any garden. Bloom first year, but of bloom the second year. Do not fail to give this a trial if interested
in Dahlias. Trial pkt., 10 cts.; pkt., 25 cts.

Dahlia Coronata. This magnificent Dahlia bears on long graceful stems which stand well out from main stem, large, single flowers of a brilliant flaming scarlet color, which exhale a delicious honey sweet fragrance. It is the only sweet scented Dahlia so far found. The petals are slightly incurved. The plants attain a height po 4 to 5 feet. The blossoms close up at night, having the 4 to the garden and for cut flowers unsurpassed, lasting for from 3 to 4 months after sowing. Pkt., 10 cts.

\section{DELPHINIUMS \\ PERENNIAL LARKSPURS}

Blue Butterfly. Can be treated as an annual although the roots are perennial. Deep gentian blue. Ht. 18 inches Plt $10 \mathrm{cts}$.

Bella Donna. A magnificent plant of branching habit, producing masses of the most exquisite turquoise blu flowers. Ht. 4 feet. $1 / 8$ oz., \$1.00; Trial pkt., 10 cts., pkt., 25 cts.

Formosum. Single rich deep blue satiny flowers with

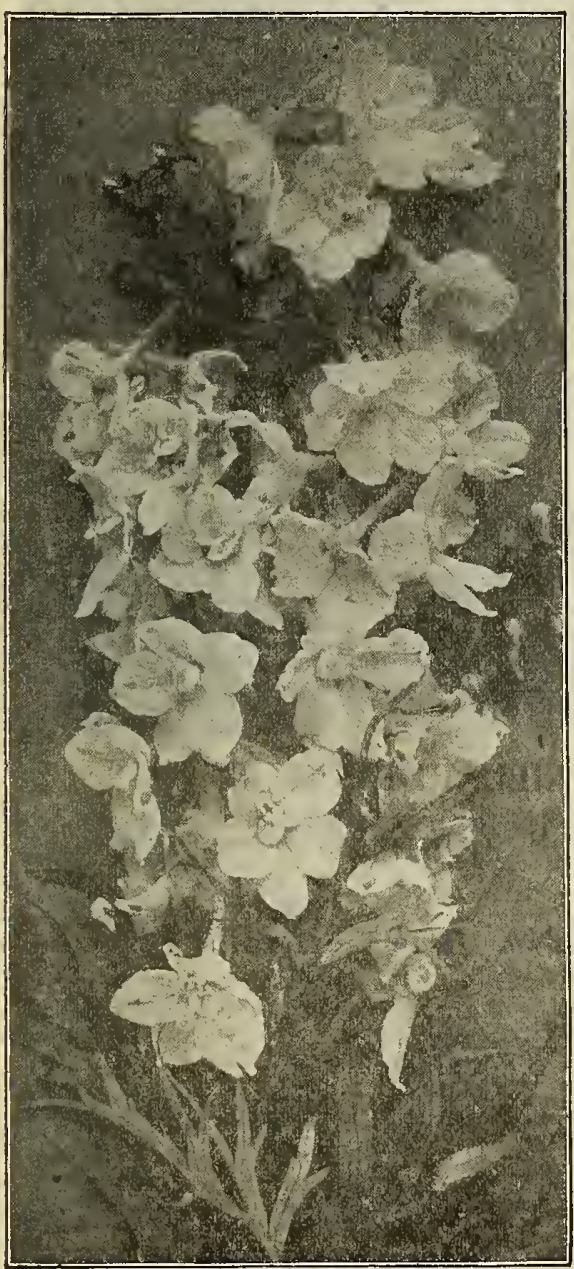

Delphinium - Bella-Donna

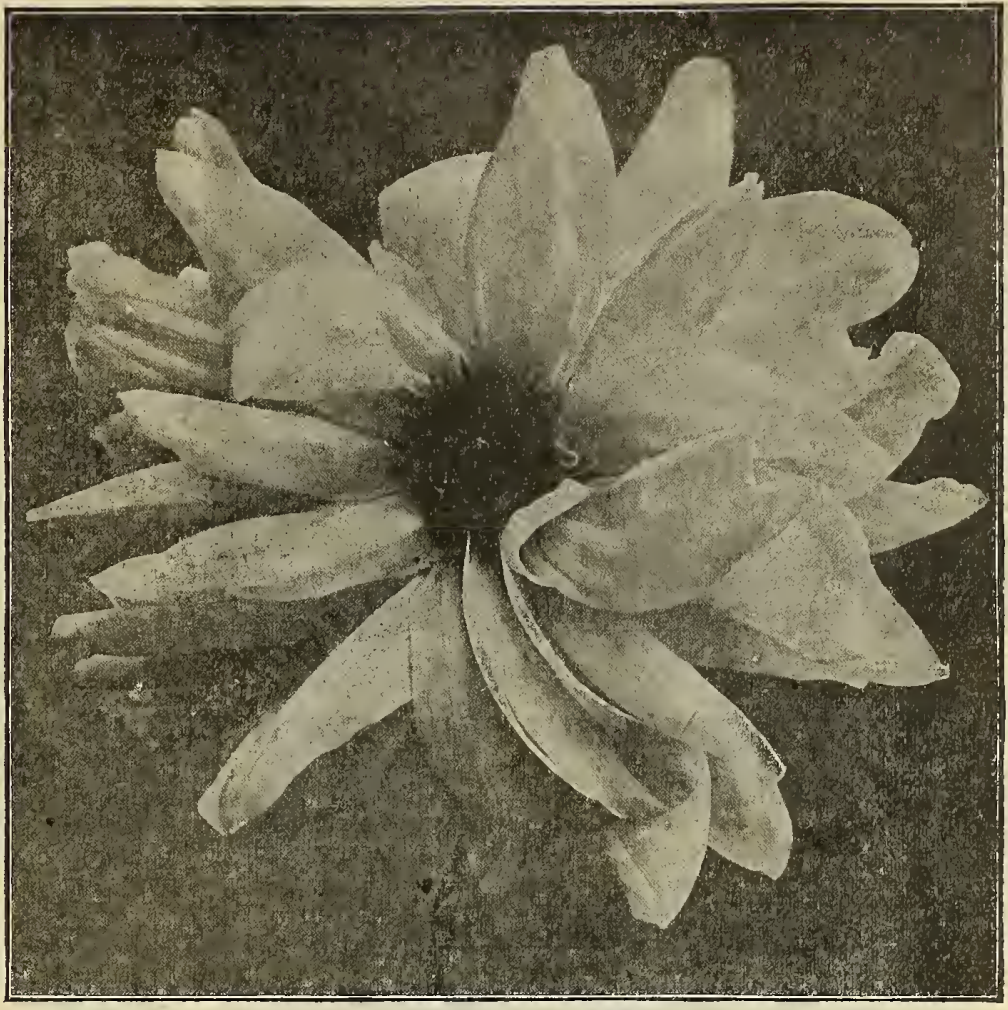

Dahlia - Mammoth

a pure white eye Very showy and effective. Ht. 2 ft. 10 cts.

Cardin ale. Tall branching plant with masses of vermilion red, very showy flowers. Brilliant and effective. Ht. 3 feet. Plkt., 10 cts.

Nudicaule. Same as preceding, but th flowers are o orange scarlet tint. Pkt., 10 cts.

Zalil. A plant of most graceful form and graceful form, flowers are pale sulflowers are pale suiand lovely shade. Ht. 3 to $3 \frac{1}{2}$ feet. Ht. 3 to $3 \frac{1}{2}$ feet. Loves shady position. Trial pkt., 10 cts.; pkt., 25 cts. DIANTHUS (Perennial Rock Pink). Cheddar Pink. A lovely dwarf plant Ht. 4 inches, elegant for edging o rockwork. Brigh rose flowers. Pkt. 10 cts.

Deltoides rosea. Another lovely pale rose flowering pale rose flowering DICTAMNUS (Gasplant or burning Bush Fraxinella) A favorite in oldfashioned gardens. Fragrant spikes of rosy flowers. Beautiful in border. Ht. 2 feet. Oz., 40 cts. pkt., $10 \mathrm{cts}$. Albus. White flowered. $1 / 40 z ., 50 \mathrm{cts}$. pkt., 10 cts.

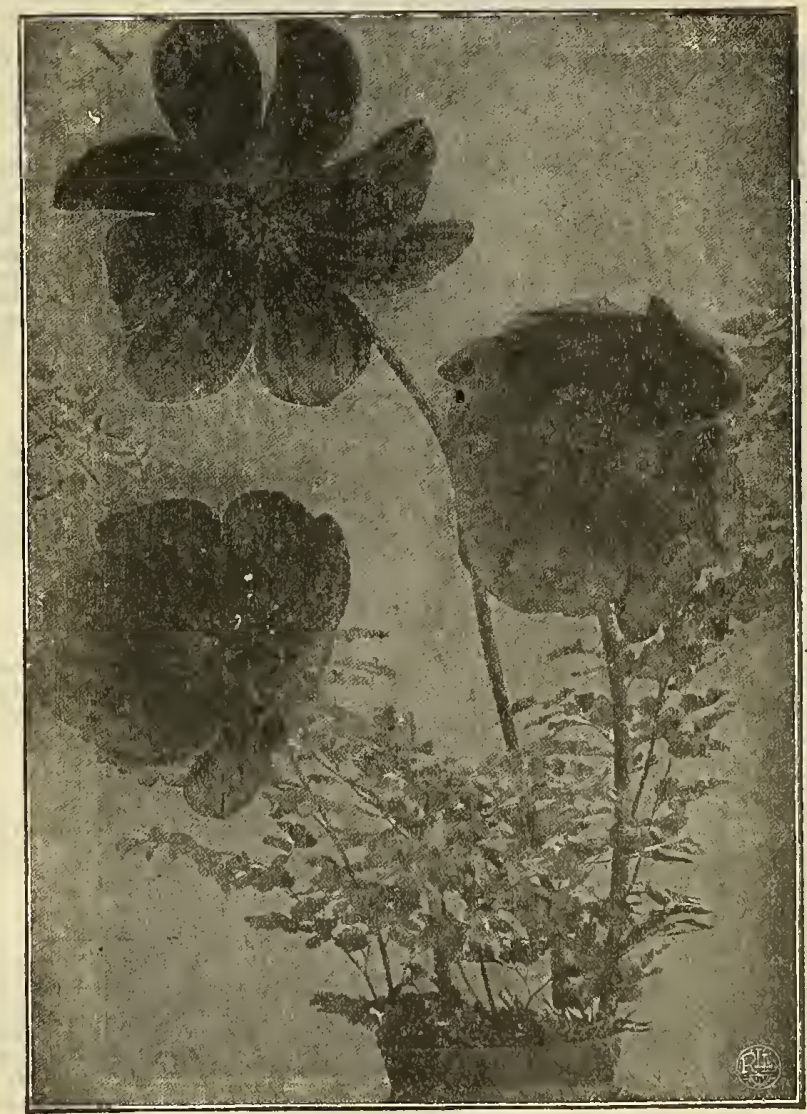

Dahlia Coronata 


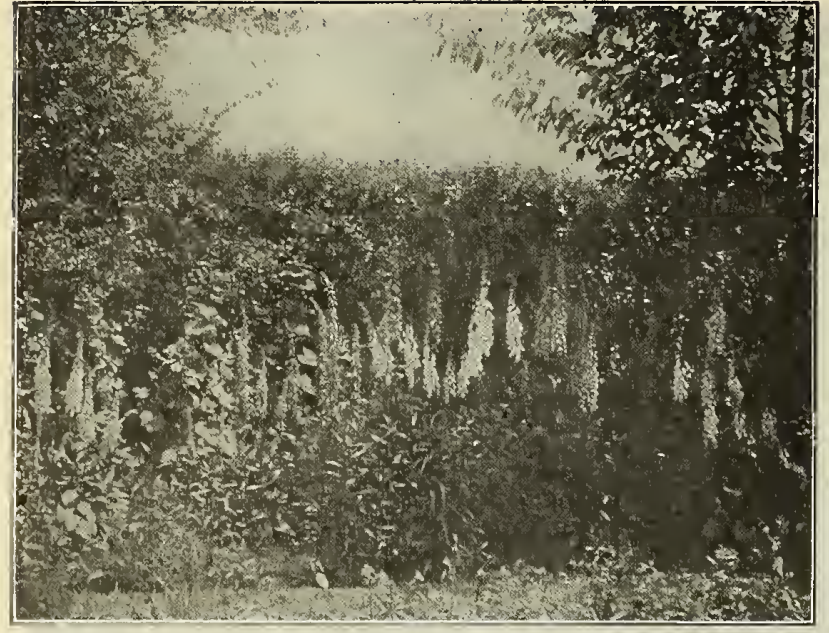

Group of Digitalis-Foxgloves

\section{ERIGERON SPECIOSUS SUPERBUS HYBRIDUS}

These are amongst the most emchanting summer flowering per pkt. The sure are amonst the most enchanting summer flowering plants. The golden disks are surrounded by ray petals of a most delicate lavender and mauve tint, like silken
fringe. The bushes, $2 \frac{1}{2}$ feet high, are smothered in these lovely blossoms. The habit of plant is compact, the flowers large and last for the longest time when cut.

$1 / 8$ oz., 40 cts...

\section{DIGITALIS}

\section{FOXGLOVE}

A more lovely plant or one easier to grow would be difficult to find. Seeds spring up readily wherever sown, in fact it is selfseeding and soon forms dense tufts of blooming plants. readily wherever sown, in fact it is selfseeding and soon forms dense turts of bloommg plants, It is especially effective in borders, for naturalizing in wild gardens, woodlands, which

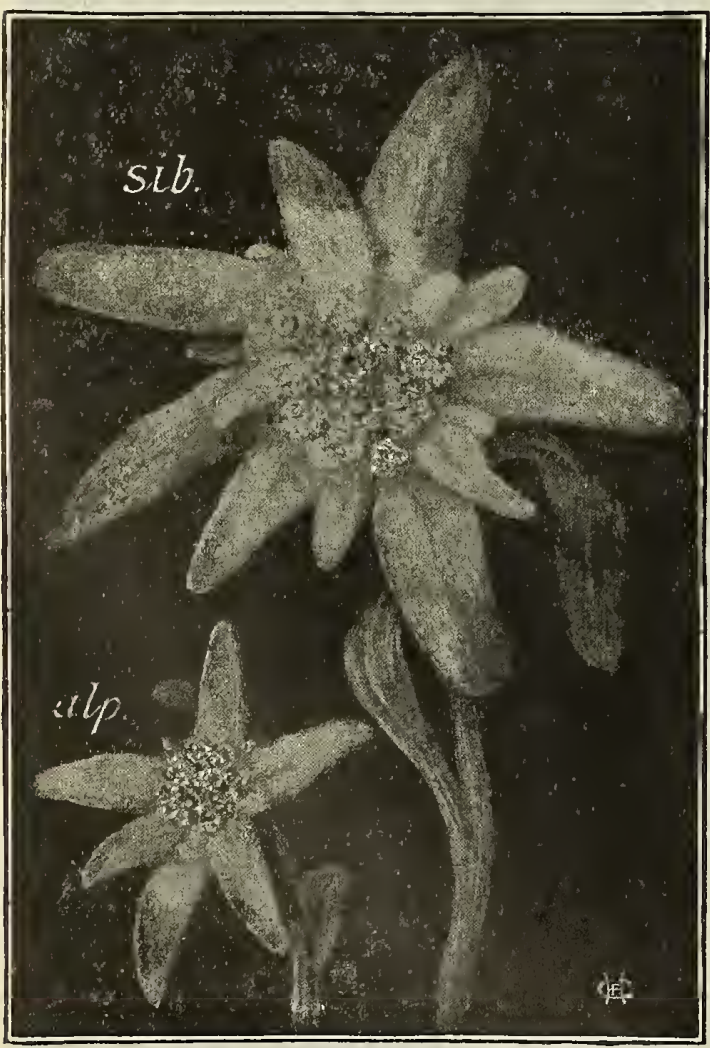

Siberian Edelweiss is its natural habitat, amongst shrubbery the tall flower spikes lend great beauty. Loves moisture and partia shade. Ht. 2 to 3 feet. Gloxinoides. Large

flowers, beautifully shady situations.
Oz., 60 cts. . .\$0. 05

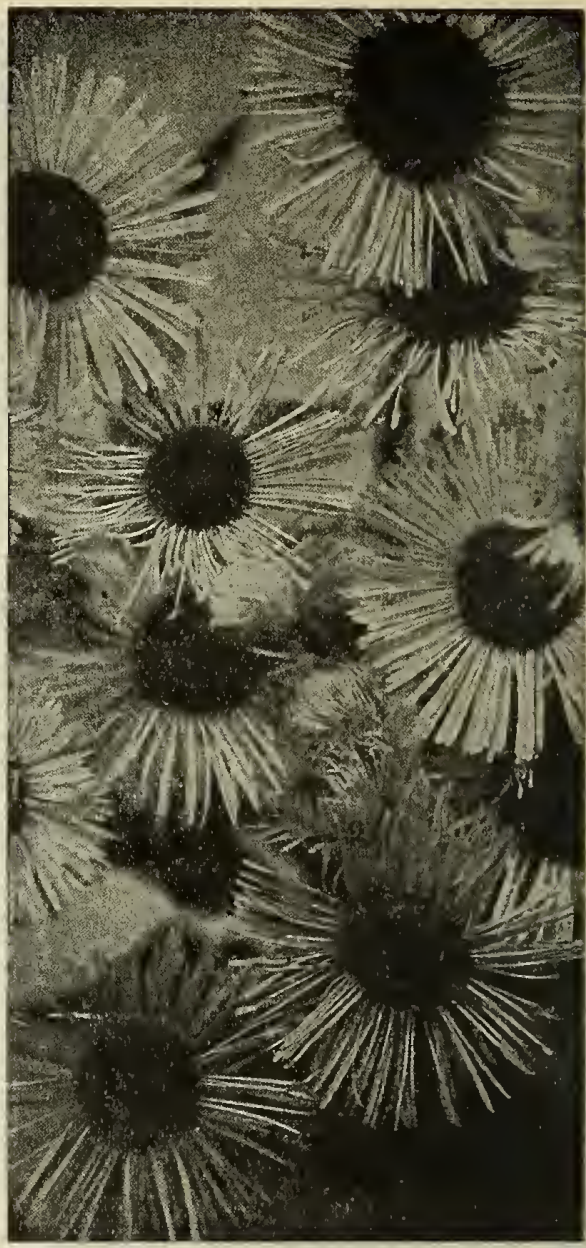

Erigeron Speciosus

Per pkt.

Purpurea. Bright rose to lilac rose and pirple.........., 75 cts. . . 05

Purpurea alba. Large white flower.................... 60 cts... 05

Ambigua. Monstrous flowers of primrose to soft yellow. A beautiful

color ................................ oz., 25 cts... . 10

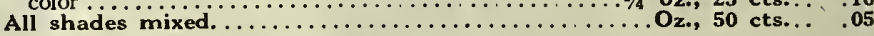

\section{EDELWEISS, SIBERIAN} Have you ever visited the Swiss Alps and seen a mass of these exquisitely
chaste flowers blooming in their home? The recollection of their beauty will chaste flowers blooming in their home? The recollection of their beauty will linger forever. To those who have not had the good fortune to see this delicate flower on its native soil; it is easy to grow it in their own home garden, and the velvety pure snowy flower will bring a sweet memory or a new delight ciently. It is easily grown, perfectly hardy and will stand severe winters

Trial pkt., 10 cts. . .

\section{GAILLARDIAS $\stackrel{\text { (Perennial }}{\text { Sorts) }}$}

Bloom the first year if sown early. These perennial Gaillardias are amongst our finest garden and border plants. The flaming colors showing all the tints of sunset make them most effective and showy ........1/4 oz., 35 cts...

\section{GENTIANA (Blue Gentian)}

Acaulis. A dwarf hardy perennial; deep blue flowers; suited to moist,

$1 / 4$ oz., 20 cts.

\section{GEUM}

A

Hardy border plants flowering, continuously from spring till late autumn Splendid for cutting, last a long time.

Mrs. Bradshaw. The flowers of this new sort are twice the size of the older sorts. Petals are wonderfully curly and frilled, wavy and very double. Color a rich dazzling scarlet. A most showy table and room decoration. Ht. 2 feet $\ldots \ldots \ldots \ldots \ldots \ldots \ldots \ldots \ldots \ldots \ldots \ldots \ldots \ldots \ldots$ Trial pkt., 10 cts... .25

Heidreichi. Has all the good qualities of Mrs. Bradshaw, the color, however, is a rich orange red. Ht. 1 foot ............. Trial pkt., 10 cts. 


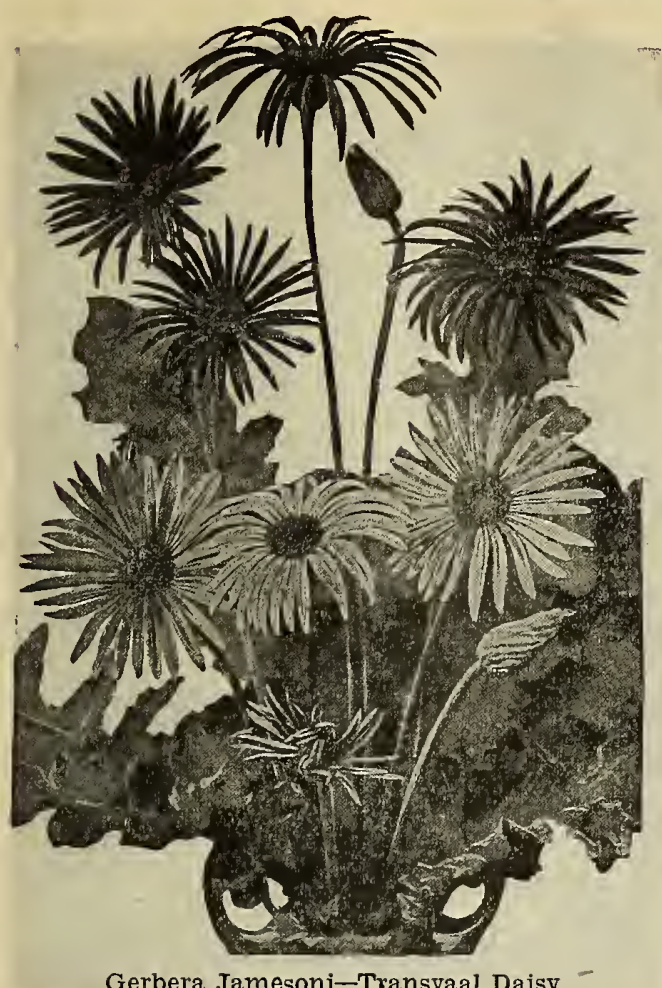

Gerbera Jamesoni-Transvaal Daisy

\section{GERBERA JAMESONI HYBRIDS}

TRANSVAAL DAISY

A gorgeous hardy Perenboth summer and winter. The flower stemsrise from the very crown of the plant to the surface to a height of 2 feet and are of 2 feet and are most graceful, bearing large soms 3 to 4 inches in diameter, with a velvety texture making them particularly beautiful. The range of color is of the widest, from pure whit through al shades of sul$\mathrm{phur}$ yellow, orange, to dazzling scarlet, rose, and blood red. Magnificent in open ground for summer and unrivalled as a pot plant in winter Trial pkt., 10 cts.; pkt., 25 cts.

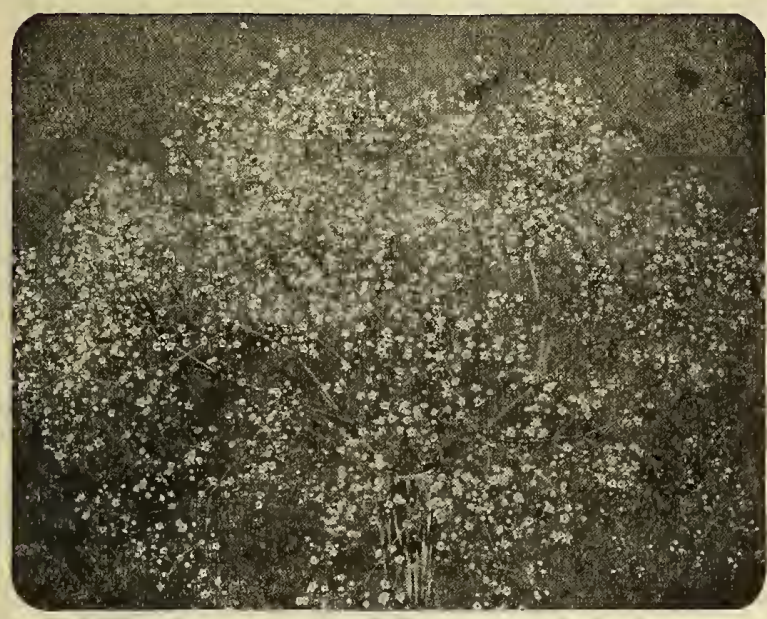

Gypsophylla Paniculata

\section{GYPSOPHYLLA PANICULATA}

One of the loveliest plants. It is smothered during Per pkt. a mass of pearly white fowers on slender stems, invaluable for cutting a mass of pearly white fowers on slender stems, invaluabe for cutting Try deep blue Delphiniums in a vase with Gypsophylla and you wili

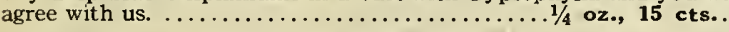

HELENIUM AUTUMNALIS (Sneeze wort). Very shawy. Most useful in border. The broad heads of golden daisy-like flowers crown the stately plants in greatest profusion. $\mathrm{Ht} .4$ to 5 feet. $1 / 8$ oz., 65 cts.; Trial pkt., 10 cts..

HELENIUM BIGELOWI. Flowers in June. Golden yellow daisy-like flower with black disk. Each flower is produced on a single stem. Ht. $2 \frac{1}{2}$ to 3 feet.......... Trial pkt., 10 cts...

HESPERIS MATRONALIS (Sweet Rocket). Stout bushy plants, 3 to 4 feet high bearing in June and July showy spikes of violet to purple flowers. Very fragrant. .1/4 oz., 15 cts.; oz., 40 cts.

HONESTY (Lunara). Rich purple flowers followed by round, flat moon-like silvery seed vessels highly prized for decorations and winter bouquets. Ht. 2 feet ................ Oz., 25 cts...
.20

.20

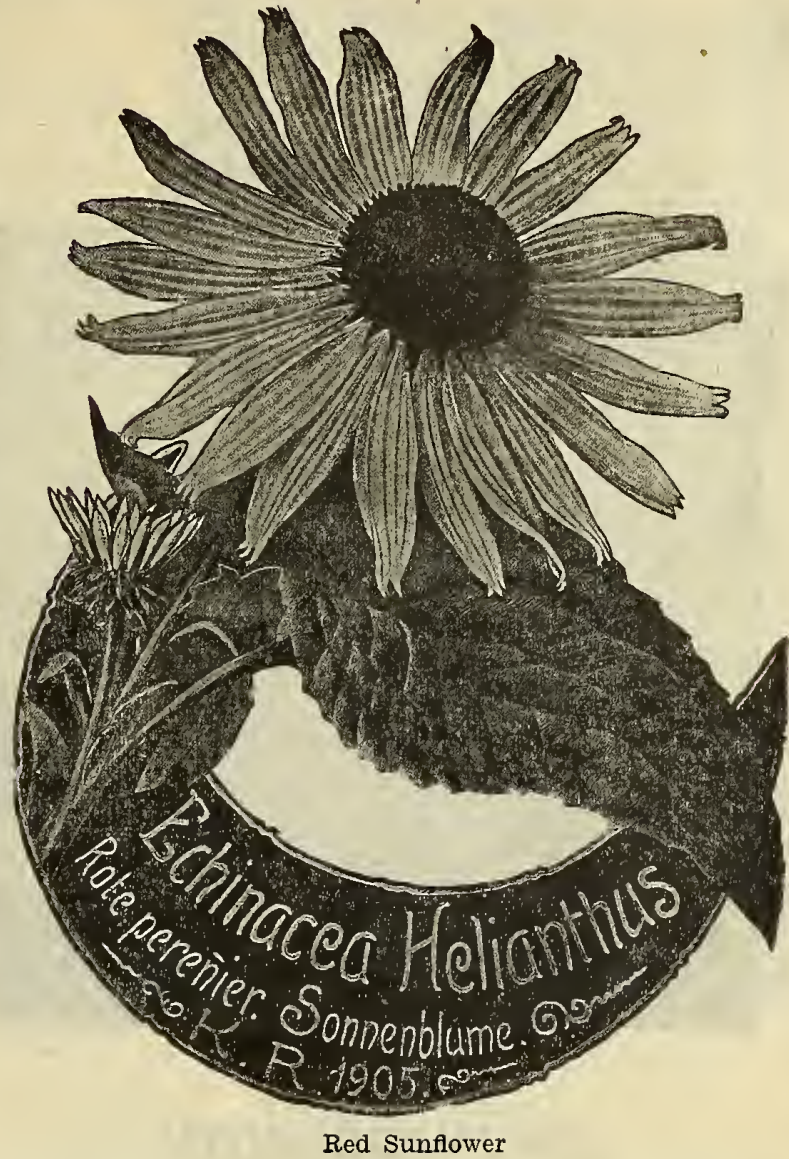

\section{HELIANTHUS-NEW PERENNIAL RED SUNFLOWER}

Per pkt.

In this we have at last secured the true red perennial Sunflower This is not the purplish red resembling the purple cone flower, but a brilliant rosy red, and perennial at that. The flowers are large, measuring 5 to 8 inches across, borne on stiff stems. The plants attain a height of $6 \times 8 \mathrm{ft}$., and are very hardy, blooming more abundantly the second year than the first. Sow the seed early, in open ground ..................... Trial pkt., 10 cts..

HELIOTROPUM. Highly prized for its delicious fragrance. Many people are unaware that this delightful flower if sown in spring will bloom the same summer, and if potted at the approach of cold weather will blossom in the house through the winter in a sunny warm place. Heliotropes are charming if treated as annuals and planted in beds with Gypsophylla or Giant Candytuft. Ht. $1 \frac{1}{2}$ to 2 feet.

Giant Mauve

Giant Dark Purple

New Climbing Heliotrope. Ht. 6 × 8 ft. Flowers are a beautiful mauve tint $\ldots \ldots \ldots \ldots \ldots$ Trial pkt., 10 cts... .25

HEUCHERA (Alum root). Very artistic and graceful plant. The foliage grows in cloudlike masses in form of a rosette near the ground being of a deep green color prettily laciniated. The wiry, slender stem are thrown up in great profusion all during the summer, each stem bearing numerous bell-like flowers of the brightest coral tint. Heucheras are ideal plants growing in the border, in rockeries or used as edgings. They lend themselves especially for unique decorations. Ht. 12 to 18 inches.

Sanguinea (The type, Coral bells). Many coral red blossoms. Ht. 15 to 18 inches ............... Trial pkt., 10 cts. \$0.15

Briziodes. A charming Hybrid. Rose pink shading to red .... .15

Convallaria. This new race differs from al! other varieties of the Alum root tribe. The $\mathbf{H}$. Convallaria develop freely branched flower stands of about 15 inches in length and 10 to 12 inches in width on strong stalks of some 18 inches in height. The individual flowers attain the size of Lily of the Valley bells. Most suitable for cutting and far more valuable than any other variety. White and rose mixed ...... Trial pkt., 10 cts. 


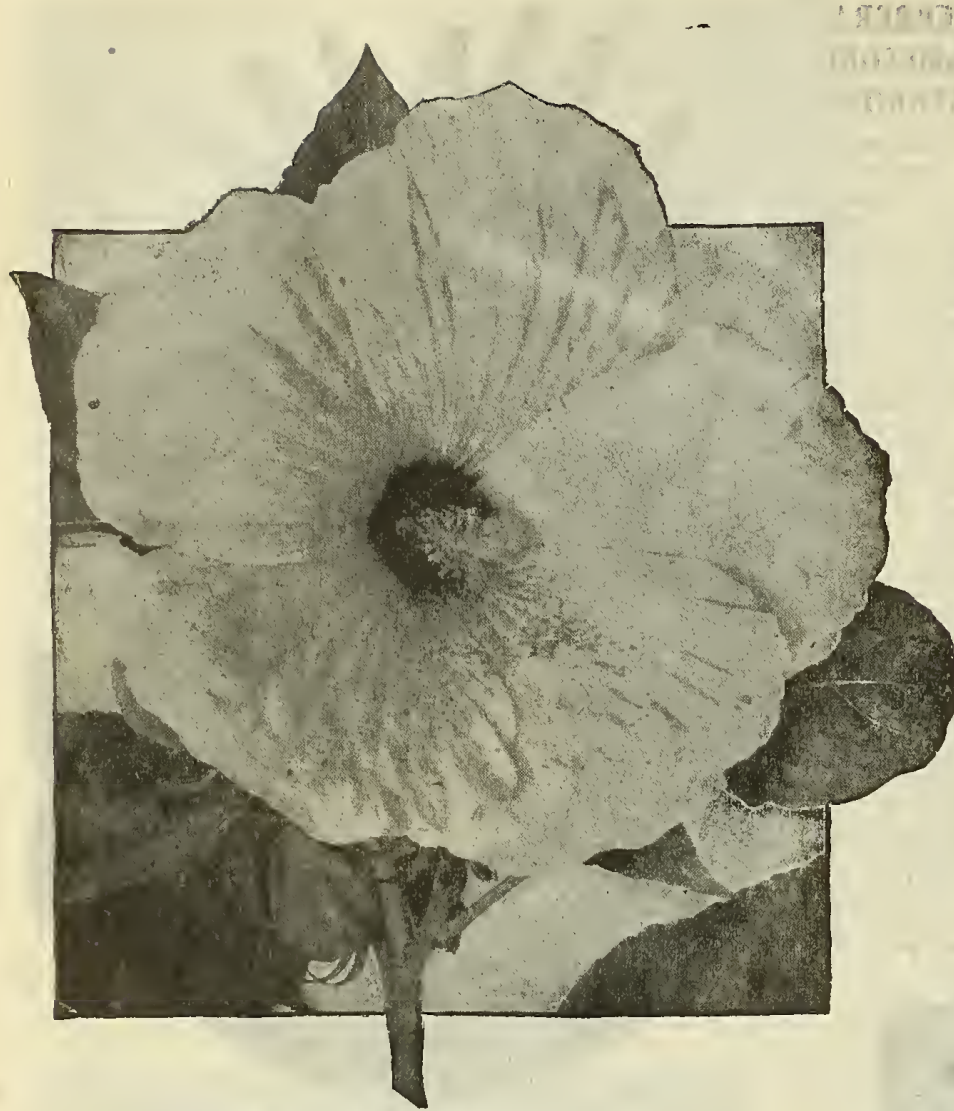

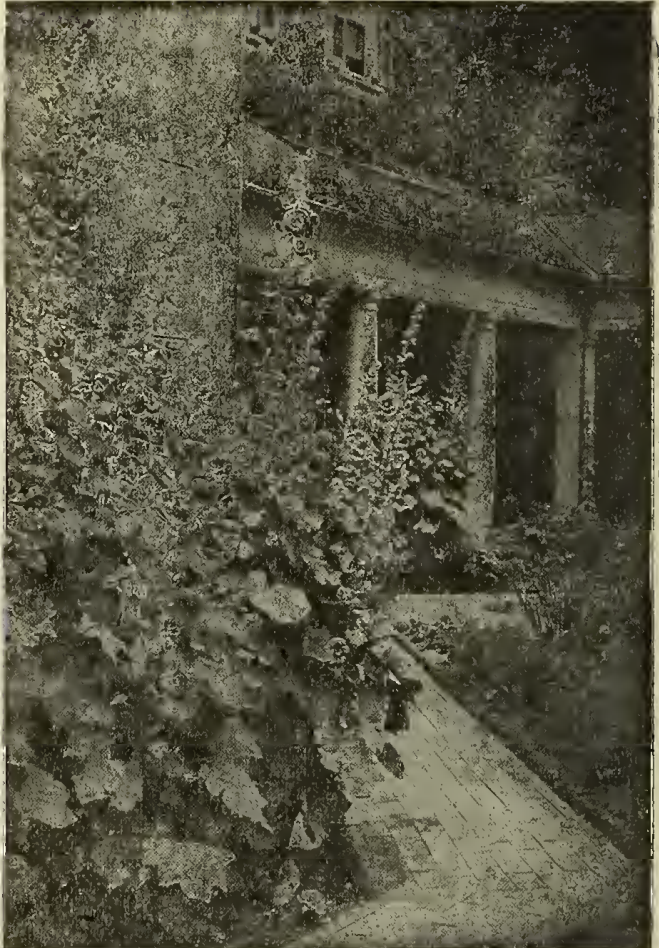

Single Hollyhock

\section{HOLLYHOCKS}

\section{NEW MARSHMALLOW}

A wonderfully improved form of our greatly admired native Marshmallow or Rosemallow, in which flowers of enormous size, frequently ten to twelve or Rosemalow, in which flowers of enormous size, frequently ten to twelve intensified, comprising rich dark red, soft mallow-pink and pure white; the plants grow from five to eight feet high and are very floriferous, blooming from early in July until late in autumn; can be recommended for plantings of all kinds, and are perfectly hardy. Sown early will flower first year.

Pkt., 25 cts.; Trial pkt., 10 cts.

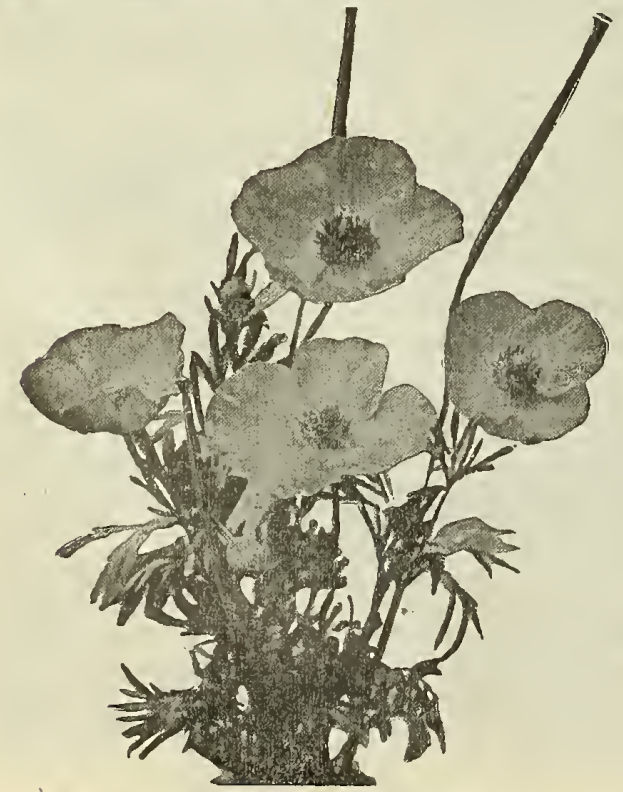

Hunnemania Fumaraefolia
For stately beauty and gorgeous effects few equal this old favorite Garden plant. Unrivalled as a background in borders, along walks, and roadways, or in groups of glowing colors. Planted near gateways the effect is particularly artistic. Hollyhocks are very gross feeders and love rich soil and a sunny situation, where they unfold their satiny petals to perfection. They are subject to rust but this can be fought off by spraying the plants when young with bordeaux mixture. After bloom is over cut the stalks and cover lightly during winter, with litter. The double Hollyhocks as in Stocks or Gillieflowers do not always come true to seed, and amongst them, single flowering will be found.

Pure White
Clear Yellow

\section{DOUBLE HOLLYHOCKS}

Rose Pink
Glowing Crimson $\begin{aligned} & \text { Rich Maroon } \\ & 1 / 2 \text { oz., } \$ 1.00 ; 1 / 4 \text { oz., } 60 \text { cts... }\end{aligned}$

\section{SINGLE HOLLYHOCKS}

Many folk love the single sorts of Hollyhocks, which show the same beautiful colors as the double and are exceedingly ornamental. Ht. of both single and double, 6 to 8 feet.

Single Pure White Clear Yellow Blush Rose

Deep Rose Bright Red Maroon

$1 / 2$ oz., 50 cts.; 1/4 oz., 35 cts... 10

Mixed double Hollyhock....1/2 oz., 85 cts.; $1 / 4$ oz., 45 cts... 10 Mixed single Hollyhock.... 1/2 oz., 40 cts.; $1 / 4$ oz., 25 cts... 10 Allegheny Hollyhock. Semidouble fringed

$0 z$ 50. $1 / 402,40$ cts.

All shades and tints are represented in the Allegheny Hollyhocks which have beautiful satiny crinkled petals.

HUNNEMANIA FUMARAEFOLIA (Giant Yellow Tulip Poppy).

A striking and most beautiful border plant. The foliage is grayish green, finely cut like Eschscholtzia. Bears on stout stems large, showy golden flowers in great profusion, appearing end of August continuing right up to frosts. Sow in open ground in May. The continuing right up to frosts. Sow in open ground in May. The

IBERIS (Perennial Candytuft).. Splendid for covering rockwork, for bordering, or for edging. Thrives anywhere in shade or sun Large flat flowerheads of pure white cover the ground like sheets of driven snow. Foliage is evergreen. Wherever established it multiplies rapidly. Ht. 9 inches ..........1/4 oz., \$1.00...

Gibraltarica. Large fragrant heads of flowers the colors running from pale lilac to blush rose. Ht. 1 foot .......1/4 oz., $\$ 1,00$. .

LANTANA (Half hardy Perennial). Of shrubby growth the plants bear verbena-like heads showing the richest shades of white, blush rose, yellow, and orange. Of especiafly beautiful effect in bedding and ideal for pot culture. Ht. 2 to 3 feet. $1 / 4$ oz., 25 cts...

Dwarf Lantanas. More beautiful than any Verbena growing. The richest sunset tints are shown in the flowers. Ht. 1 foot. Trial pkt., 10 cts... 


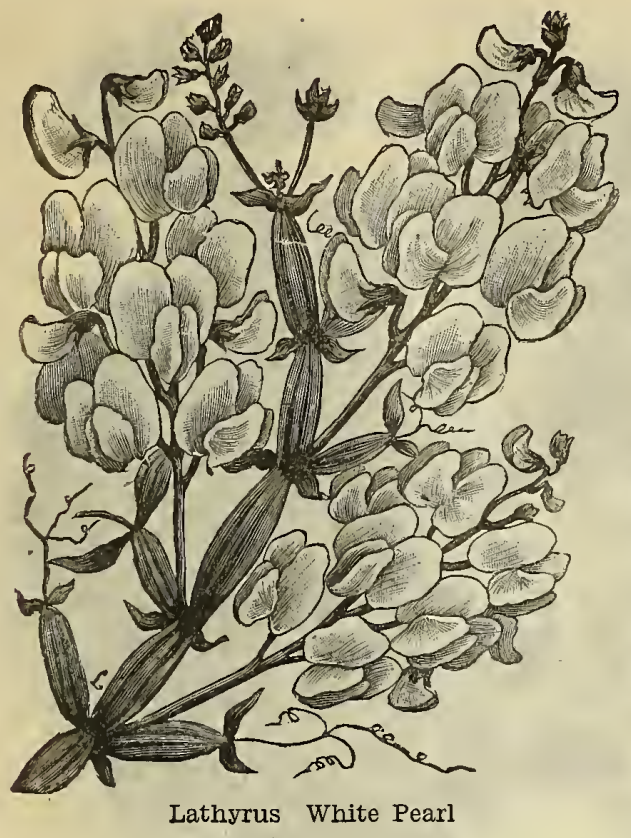

LATHYRUS LATIFOLIUS

\section{(Perennial Peas)}

Resemble in every respect the sweet peas-the large flowers growing in rich clusters on single stems. They flower in greatest profusion throughout the summer. Are very decorative but are not fragrant. Per pkt. White Pearl. White, large clusters. . Oz., 65 cts.; 1/4 oz., 20 cts... $\$ 0.10$ Pink Beauty. Bright rose, clusters of flowers like rosy butterflies

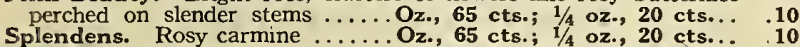
All colors mixed ................. Oz., 50 cts.; 1/4 oz., 15 cts... . 10

\section{LYCHNIS}

Chalcedo nia (Jerusalem cross). Showy and effective Border Perennial. Flat heads of brilliant geranium red flowers. Ht. $2 \frac{1}{2}$ to 3 feet. Sow in open ground in spring. Fine for cutting. $1 / 2$ oz., 25 cts..

Haageana. From the tuft of bright green leaves rises a single stem

Haageana. From the tuft or bright green leaves rises a single stem
bearing one large orange red flower formed like a Maltese cross. Fine for flower border and rock work. .......1/8 oz., 25 cts...

\section{LOBELIAS}

Cardinalis. Ht. 2 to 3 feet. Bronze green foliage from which rise rise the single stout stems bearing flowers of intense fiery scarlet rn both sides Blooms August to October. The plants thrive best in a rather moist soil and a sunny place.

$$
\text { Trial pkt., } 10 \text { cts.; } 1 / 8 \text { oz., } \$ 1.25 \text {. }
$$

Lobelia Tupa (Devil's Tobacco). A magnificent novelty. Resembles a gigantic Lobelia Cardinalis. 6 to 8 feet high. Bears in abundance, curiously peaked flowers, fiery scarlet, $21 / 2$ inches long. Foliage is a beautiful bright green. . Trial pkt., 10 cts..

\section{MALVA-(Mallow)}

Belong to the Hollyhock family. A very showy perennial, blooming continually from. June to October. Loves moisture and a sunny situation. Fine for cutting. Ht. 2 feet.

Moschata rosea (Musk Mallow). Produces in great abundance large deep rose flowers...................1/8 oz., $30 \mathrm{cts} .$.

Alba. A pure white form .....

\section{MIMULUS \\ (Monkey flower)}

Very interesting showy flowers ranging in all colors from primrose to yellow orange and flame color to golden brown. Spotted and mottled and blotched some with hieroglyphic designs on the petals. The flowers resemble in shape the Snapdragons. Thrive best in warm and moist places near watercourses where they soon establish themselves and form patches of brilliant coloring. Ht. 1 foot.

Cardinalis Grandiflorus. Large scarlet flowers. Ht. 1 foot ..... .10

Tigrinus Grandiflorus. Flowers large, and of various shades of

yellow, elegantly spotted and marked with crimson and maroon.

Mixed Mimulus .................................. .10

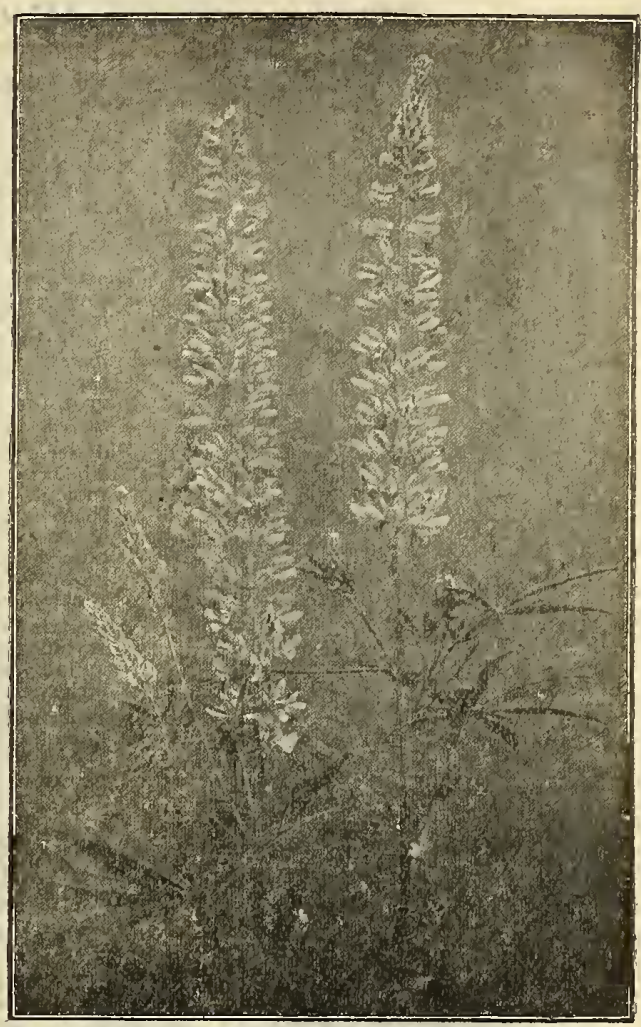

Lupinus Polyphyllus

\section{OENOTHERA}

\section{(Evening Primrose)}

There are flowers for all times of the day, these are for the evening They open wide their beautiful poppy-like blossoms or the evening. and exhale their sweet fragrance at a time when it is most appreciated It is a most refreshing scent, and the flowers shine like little moons in the It is a most refreshing scent, and the flowers shine like little moons in the
twilight.

Fraseri. Bushy plants covered with golden yellow flowers with reddish stems. Ht. $11 / 2$ feet.

Lamarkiana. Giant Evening Primrose. Tall erect spikes of immense bright yellow blooms. Unexcelled for naturalizing. Ht. 3 feet ......................1/4 oz., 20 cts...

Miss Perkins. Throughout summer on long trailing stems, amidst soft silky foliage shine masses of rich yellow blossoms. The foliage turns a brilliant red in fall. Loves warm sunny spots. Very useful for banks, rockeries or borders... $1 / 4$ oz., 30 cts.

Acaulis (Taraxifolia). Trailing habit. Large creamy white flowers, blooming profusely throughout summer. Charming for banks; borders, rockwork ..............1/4 oz., 35 cts..

Mixed Enothera $\ldots \ldots \ldots \ldots \ldots \ldots \ldots \ldots \ldots 1 / 4$ oz, 30 cts... .10

\section{HARDY POLYANTHUS PRIMULA ELATIOR}

With the Crocuses and the Daffodils bloom these sweet spring flowers. They should be cultivated by all and every flower lover for their great charm and beauty. The seed we offer has been saved with special care by an expert. It embraces all shades and tints, white, rose, sulphur yellow, ruby red, gold laced, blue, crimson. These primulas delight in half shady nooks, naturalize superbly in the wild garden along woodland paths, amongst rocks, etc. Planted along the border they charm with their glorious colors. Protect in winter with litter, leaves, etc. ......... Trial pkt., 10 cts..

Primula veris (Common English Primrose). Large heads of bright yellow, sweet scented ............... 1/8 oz., 25 cts...

Cowslip. Large flowered, mixed colors ........1/8 oz., 15 cts..

Do not fail to give our 1918 Flower Novelties a trial. They are sure to please you. 


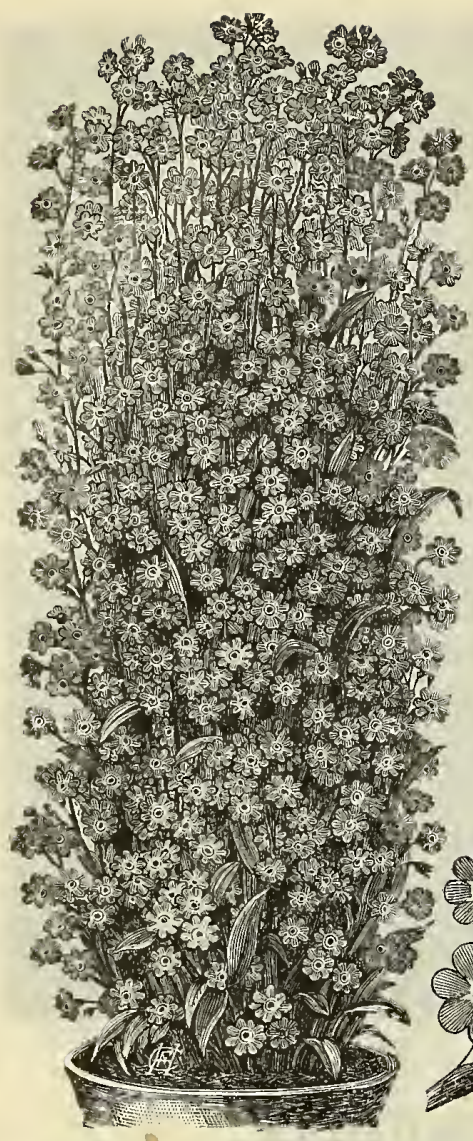

Myosotis Alpestris Stricta Grandiflora

\section{MYOSOTIS}

Do you know of any sweeter flower than our Forget-me-not: one closer associated with dreams and fancies? Wherever seen it greets us as an old friend. So easily grown, so enchanting. Grown along wood-lands, along paths, in the border, in pots, lends itself to any situation.

Dissitiflora. A very hand- Pkt. some early sort blooming so profusely and of such compact growth it has the appearance of a sheet of blue when inches. $1 / 8$ oz., 35 cts. . $\$ 0.10$

Palustris semperflorens. The true water Forgetme-not. Loves a partly shady and damp situation. Flowers bright blue with yellow eye. Flowers all summer. Ht. 9 inches. $1 / 8$ oz., 35 cts. .

Alpestris Victoria. Large skyblue flowers growing n long sprays. $\mathrm{Ht}$. inches. $1 / 4$ oz., 65 cts...

Alpestris stricta grandiflora (Pillar shaped Forget-me-not) (S e e picture). This charming sort flowers Azure blue, pure white, andbright rose. Separate colors, each.... Three packets, one Triumph. A very early flowering sort blooming eight weeks afterr sowing. Very each stem bear ing a rich cluster of brightsky blue flowers. Trial pkt., 10 cts. . . 25

\section{MYOSOTIS RUTH FISHER}

The best novelty to date. Forms compact bushes 12 inches in diameter, smothered with sprays of heavenly blue flowers. Each individual spray is composed of from 8 to 10 gigantic blossoms. For edging, for bedding, for pot plants, this is certainly the most beautiful variety known. It is absolutely hardy and with little protection survives severe winters. If taken up late in fall and brought in the house this sort will make charming pot plants for the winter garden.

All sorts of Myosotis mixed .............1/8 oz., 25 cts.

\section{PHLOX DECUSSATA}

\section{(Hardy perennial Phlox)}

These beautiful plants embrace an incredible range of colors and tints. From pure white to rose, lilac, purple, all shades of scarlet, red, maroon through yellow, cream, salmon, to coral red, their large flower heads decorate a garden as nothing else will. Given a fairly good soil they thrive anywhere. Give an abundance of water especially during the flowering period. The old plants should be divided every third season as they otherwise get worn out. Ht. 3 to $3 \frac{1}{2}$ feet.

The seed is not quick to germinate. Takes from 2 to 3 months. The seed does not always come true to exact shade. We recommend the purchase of plants where certain shades are wanted.

Mixed Phlox Decussata................1/4 oz., 60 cts...

.10

PHYSOSTEGIA VIRGINIANA (False Dragon head). Very beautiful border plant. Produces from July to September many long straight spikes completely smothered in delicate tubular rose blossoms. Valuable for cutting. Ht. 3 feet. .1/8 oz., 40 cts.

\section{POPPY. Papaver.}

All perennial Poppies may be sown from April to June to bloom the following summer.

Alpine Poppy. Papaver Alpinum. Charming dwarf Poppies with delicate flowers including yellow, white, scarlet and pink, $1 \mathrm{ft}$. White, Pink, Orange-yellow, Mixed.

Each of the above colors and mixed, Pkt., 15 cts.

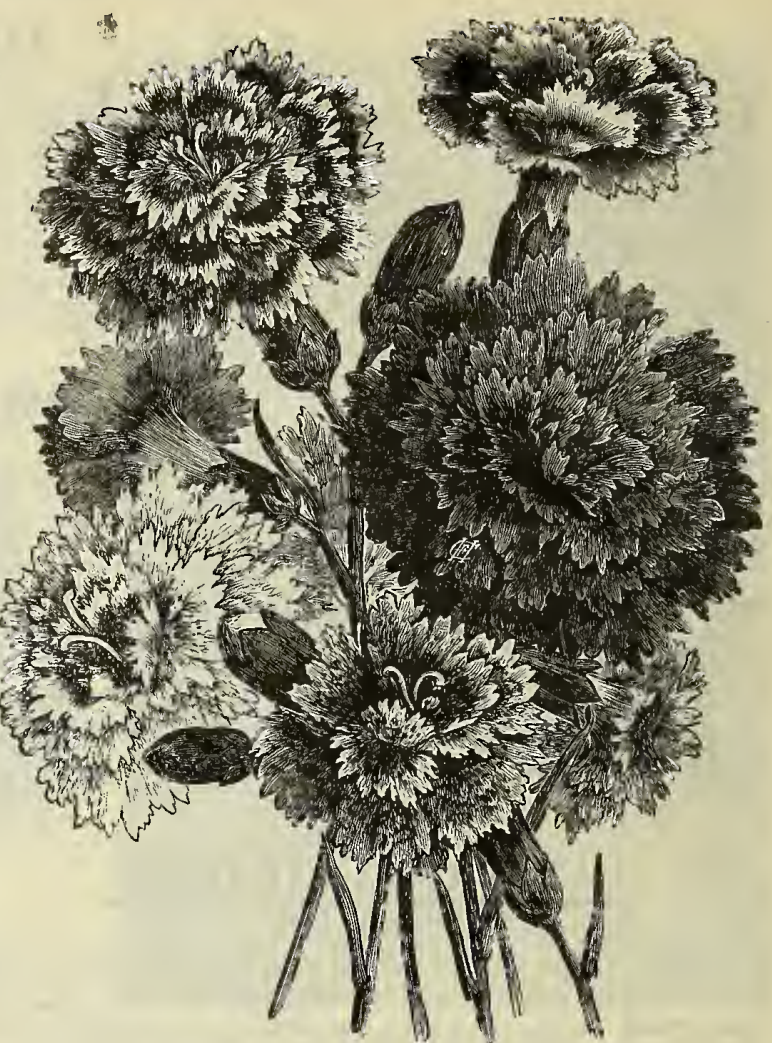

Double Perennial Princess Pinks

Per pkt.

These fragrant pinks are the old-fashioned gardener's delight. Semidouble and double in all colors, white, rose, crimson, carmine, many having a crimson centre; broad petals. Deliciously fragrant. $\mathrm{Ht}$. 12 to 15 inches. Mixed................1/8 oz., 35 cts..\$0.05

Cyclops. Large single flower in rose and crimson shades, with darker centre. Unexcelled for cutting, lasting a very long time. Ht. 15 inches $\ldots \ldots \ldots \ldots \ldots \ldots \ldots \ldots \ldots \ldots \ldots \ldots \ldots \ldots \ldots \ldots \ldots .1 / 8$ oz., 35 cts...

Mrs. Simkins. This seed is difficult to obtain. The flowers are very large, double, pure white, a truly royal flower. Of spicy clove scented fragrance. Ht. 12 to 15 inches.. Trial pkt., 10 cts... . 25

\section{PENTSTEMON}

A great favorite for the perennial border. The large Gloxinia-like flowers in their brilliant shades attract much admiration.

Digitalis. Large white flowers with violet spotted throat. Ht.

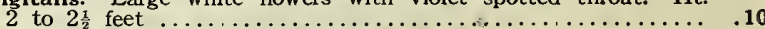
Spectabilis. Blue and red shades very showy. Ht. 2 feet....... .10

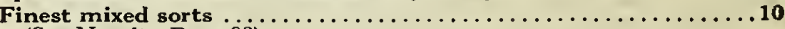
(See Novelty Page 00)

\section{PERENNIAL POPPIES}

Poppy Orientale. Flashing their magnificent giant blooms above the elegant grayish green foliage they may be well called kings of the the elegant grayish green foliage they may the Royal Darwin Tulips garden. They rival in gorgeous beauty the Royal Darwin The stout and are one of the showiest, most effective flowers grown. The stout stems rise to a height of 3 and 4 feet. Carpet the ground with lberis sempervirens (Perennial Candytuft) and the sight is worthy of a painter's brush when the flowers bloom. For decorations Poppy Orientale is matchless. Note that the flowers last longer and retain their marvelous satiny appearance much longer if cut early in
chalixes open. This applies to all sorts of Poppies.

Poppy Orientale The Type (Queen of the Orient. Im. mense flowers of orange scarlet $\ldots . \ldots \ldots \ldots \ldots \ldots \ldots \ldots . . .10$

Beauty of Livermore. Crimson with black blotch, enormous

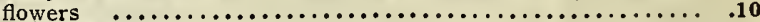

Queen Alexandra. Bright rosy salmon with conspicuous crimson blotch. Very distanct ....................... 10

Salmon Queen. A golden salmon yellow. Magnificent..... .10

Rembrandt. A gorgeous flower. Immense orange scarlet blossoms . .........................................10

Novelty. Mixture of Rose, Lilac, and Mauve shades. The beauty of these flowers is indescrible.. Trial pkt., 10 cts... .25

Excelsior. A very fine mixture ranging in tints from delicate salmon to deep crimson $\ldots \ldots \ldots \ldots \ldots \ldots \ldots \ldots \ldots \ldots \ldots . .10$ 


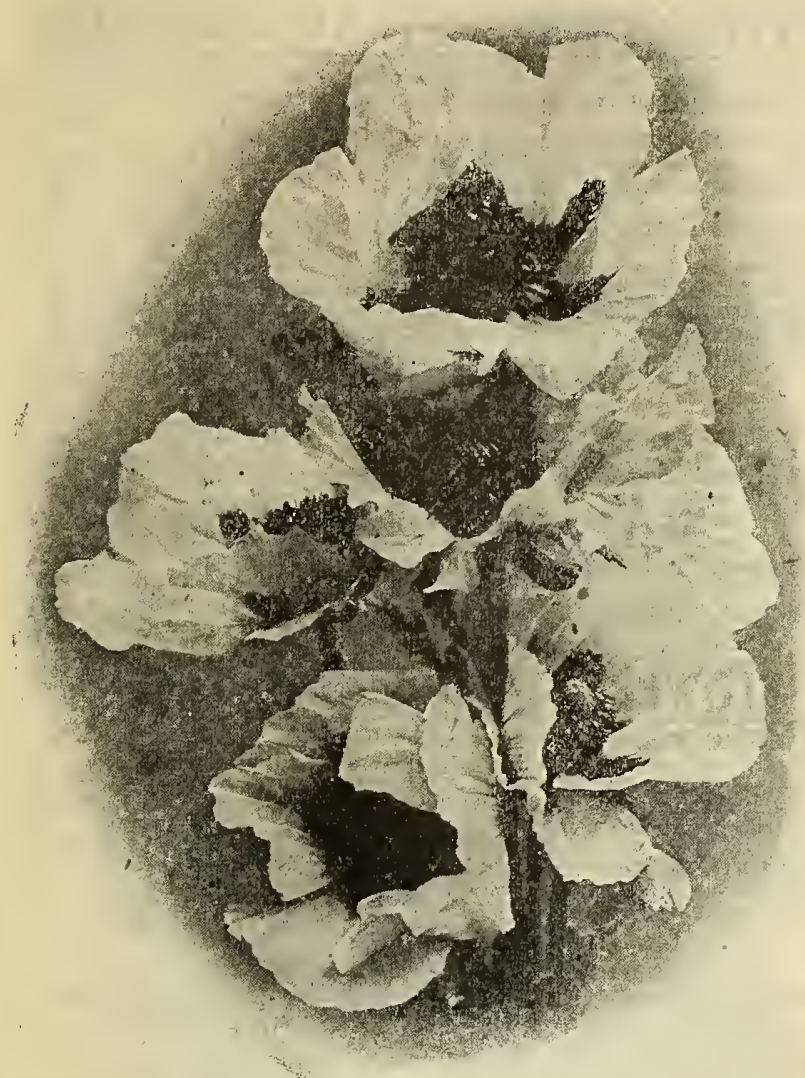

Poppy Orientale

Note. Do not transplant Oriental Poppies except in late fall when they are entirely dormant, having a long taproot; removal while in full growth often causes the plant to die.

\section{ICELAND POPPIES}

(Papaver Nudicaule)

Per pkt.

For cutting for table decorations these flowers are unexcelled. The colors appear fairy-like under artificial light, coming out in all their richness and purity. The slender leafless stems rise from a tuft of delicate sreen laciniated foliage bearing alof cup-shaped flowers of delicate green laciniated foliage bearing alof cup-shaped fowers in shades of white, rose, salmon, coral pink, and citron yelow. Plant for best effect amongst border shrubbery, in large masses, and in
rockeries. Iceland Poppies love sunshine. Ht. 12 to 15 inches. All shades mixed $\ldots \ldots \ldots \ldots \ldots \ldots \ldots \ldots \ldots \ldots \ldots \ldots 1 / 8$ oz., 40 cts.. $\$ 0.10$

\section{ALPINE POPPIES}

Delicious Miniature or Fairy Poppies. Petals which seemingly a mere breath would destroy so fragile, so delicate are they. Their loks belie them as the dainty flowers keep their own lasting for looks betie the as the dainty flowers keep their own, lasting for days. The foliage is fernlike, silvery. For border or rockwork

the flowers are unique. Ht. 9 inches. ...................... Double

OTENTILLA. Flowers profusely all through summer. Double
flowers are borne in bunches. Ht. 18 inches. Shades range from rose to red and scarlet.

Mixed Finest Hybrid

\section{PYRETHRŪM}

Very decorative border or bedding plant. The single leafless stems rise from a tuft of finely cut foliage 20 to 24 inches high. Mixture of White, Blush Rose, Crimson. Ht. 2 feet. . $1 / 8$ oz., 35 cts..

Comet Flowered. These varieties are remarkable and varied in form of petals. Some are rolled into quills, others are twisted like Cactus Dahlias, some entangled like Comet Asters. The individual flowers are 2 to 3 inches across, the colors all delicate and brilliant. For cutting and keeping qualities, Comet-flowered Pyrethrums are For cutting and keeping qualities, Comet-flowered Pyrethrums are
unsurpassed $\ldots \ldots \ldots \ldots \ldots \ldots \ldots \ldots \ldots \ldots \ldots \ldots \ldots \ldots \ldots$
oz., 50 cts...
RUDBECKIA Cone

Produces in fall rich orange yellow flowers with chocolate maroon disk. A fine border plant. Good for cutting. Ht. 3 feet.

Newmanni. Magnificent large yellow flowers with dark centre

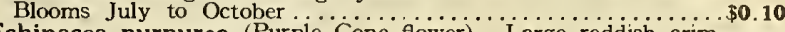

Echinacea purpurea (Purple Cone flower). Large reddish crimson flowers. Ht. 3 feet ............. Trial pkt., 5 cts...

SALVIA PATENS (Perennial). Large beautiful gentian blue flowers on tall spikes. Blossoms the same season from seed sown early in spring in the house. Or in the open in May.

SAXIFRAGA. The gardener's delight for use in rockwork, for edging, and for borders. The fleshy stout stems rise from a mass of broad round glossy green foliage which is in itself ornamental and bear fascinating bell-like flowers in varied tints of white, rose crimson, purple. Ht. 9 to 12 inches.... Trial pkt., 10 cts...

\section{SCABIOSA $\begin{gathered}\text { Pincushion } \\ \text { flower }\end{gathered}$}

\section{PERENNIAL SORTS}

Caucasia. A beautiful sort. Flowers a lovely delicate lavender. Ht. 2 feet..................... 1/8 oz., 25 cts... Caucasia alba. Same form as the lavender, but flowers a pure white.......................... Trial pkt., 10 cts...

\section{NEW HARDY SCABIOSA CAUCASIA}

Diamond. A wonderful coloring of shiny blue black; strong and rapid growth, and immense productiveness. ... Large pkt., 25 cts... Perfecta and Fimbriata, mixed. Magnificent large blue flowers with wavy fringed petals borne in masses on strong, tall stems. Bloom from July up to heavy frosts. Unsurpassed for cutting. Large pkt., 25 cts. .............................

SEDUM (Stone Crop). A gem wherever carpeting effects are desired, quickly covering rocks and stones with a mosslike effect; content with the shallowest soil. When in bloom it resembles sheets of delicate colors. Ht. 4 inches. All colors mixed. Trial pkt., 5 cts...

\section{STOKESIA CYANEA}

(Cornflower Aster). Bears from July to October, masses of large, light blue flowers, resembling beautiful semi-double Asters. Ht. 2 feet. In every respect ike the blue flowered $1 / 8$ oz., 25 cts. are a pure white. Ht. 2 feet............. $1 / 8$ oz., 35 cts.

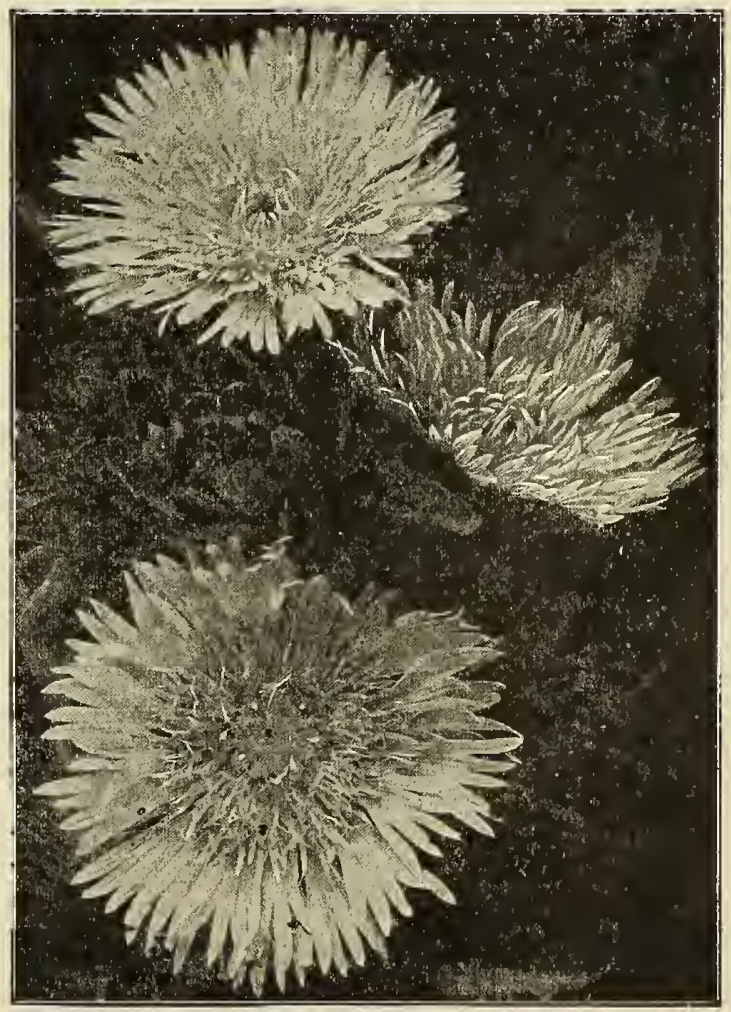

Stokesia Cyanea 


\section{SWEET WILLIAM (Dianthus barbatus)}

A well-known, attractive, free flowering plant, producing splendid effect beds and borders with its rich and varied flowers.

Single. White, Red, Rose, Pink, Crimson and Mixed....... Pkt. $1 / 40.10$ oz.

Double. White, Rose, Maroon, Pink, Mixed ............. .10 $\quad .25$

Newport Pink. A distinct new color originated in one of the far famed gardens at Newport, R. I. A rich salmon rose, brilliant and beautiful. The flowers are borne in massive
heads on stems I 8 ins. high. Unenualled for bedding. 2 pkts., 25 ets. .

Scarlet Beauty. Rich deep scarlet variety...............15 Holborn Glory. Auricula-eyed, the most beautiful and admired of all Sweet Williams.........1/4 oz., 25 cts... $\quad .10$ Viola Cornuta (Tufted Pansies).......1/4 oz., $\$ 1.00 . . \quad .10$

\section{SEA HOLLIES}

Eryngium. Thistle-like heads of steel blue. Very effective in borders, lawn or wild garden.............. Trail pkt., 10 cts... E. GIGANTEA (Ivory Thistle). Foliage and flowers glittering silver white............................. Maritima (True Sea Holly). Very handsome. Trial pkt., 10 cts... $\quad .25$

\section{EVERLASTING or STRAW FLOWERS}

(Note.-Always cut the flowers which are to be dried before they are fully expanded, and hang heads down in an airy and cool place.)

Acroclinium (Fairy Immortelle). Fine for summer borders Ht. Ift. Double white, rose or mixed............. Oz., 25 cts...\$0.05 Ht. Ift. Double white, rose or mixed............. $z_{\text {. }}, 25$ cts... $\$ 0.05$
Ammobium Alatum. Starry and lovely. Pure white. Ammobium Alatum. Starry and lovely. Pure white. 25 ets... 05 Amaranth (Gomphrena globosa). Fine for beds or edging. Purple,

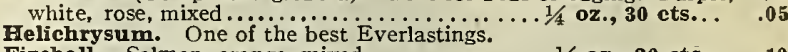

Fireball. Salmon, orange, mixed $\ldots \ldots \ldots \ldots \ldots \ldots 1 / 8$ oz., 20 cts... $\quad .10$

Rhodanthe Manglesii. Rose or white...........1/8 oz., 25 ets... .05

All sorts mired...........................1/8 oz., 15 ets... .05

\section{VIOLA ODORATA}

Sweet Violet needs no description. It is the flower of love and romance. The Czar. White or blue $\ldots \ldots \ldots \ldots \ldots \ldots \ldots \ldots 1 / 8$ oz., 30cts...\$0.10

\section{STATICE SEA-LAVENDER}

Suworowi. Tall spikes covered with exquisite rosy flowers.

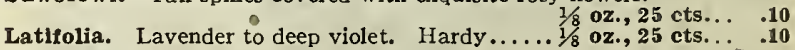

\section{FLOWER SEED MIXTURES for CUT FLOWERS, WILD NOOKS, Etc.}

ANNUALS. This superb mixture includes early medium and late sorts thus assuring a continuity of bloom from June till frost. Can Pkt. be easily grown by any one with little care and in any good common soil. One yearly buyer calls this his "Crazy in any

Oz., 30 cts.. $\$ 0.10$

PERENNIALS. This is a very choice mixture which we mix ourselves combining all varieties and colors. Ideal for gardens where the novelty of seeing something new springing up is desired. Oz., 50 ets.; $1 / 4$ lb., \$1.50.. .10

\section{THE GOURD FAMILY}

One of the favorite ornamental climbers. Many fantastic fruits are found amongst the gourds. They are all annuals, grow very rapidly and are most interesting.
Pkt. Dipper or Calabash also called Chinese Bottle Gourd Dishcloth. Chinese Loofa or Sponge Gourd....... Oz., 50 cts... $\$ 0.05$ Gooseberry. Small green fruit resembling gooseberries Hercules club. The boy in the picture holds it in his hand Nestegg Gourd. White, size of a hen's egg. Much used for hen's nests. Orange. S. Small fruit. Highly prized for its fragrant aroma which will perfume a whole room . ......................40 cts...

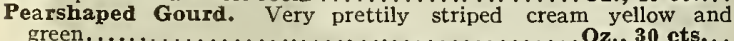
Serpent Gourd. 3 to 5 feet long, slender and striped like a serpent Sugartrough. Old-fashioned Sap bucket.... Oz., $\mathbf{3 0}$ cts... Turk's Cap. Turban shaped Mixed Gourds all kinds........................ 25 cts... Collection of the ro so............ rts listed, one of each packet,.

\section{CLIMBING PLANT SEEDS}

ADLUMIA CYRRHOSA (Mountain Fringe). The foliage resembles Maidenhair Fern. Flowers delicate pinkand white.

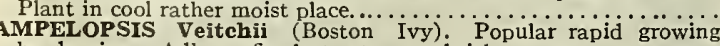
hardy vine. Adheres firmly to stone or brick BALLOON VINE. Length is feet. Very rapid grower. White flowers. The seed pods are shaped like miniature balloons... . .... COB $₫ A$ Scandens (Cathedral bells). Climbs thirty feet in a season. Flowers are bell shaped. Plant the seed edgewise and cover lightly. Purple or white................................. Clematis Coccinea. The scarlet Clematis. Flowers are of a rarely
beautiful pitcher shape. Color a bright orange scarlet. Delicate beautiful pitcher shape. Color a bright orange scarlet. Delicate CYPRESS VINE (Ipoma Quamoclit). Dark green feathery foliage, innumerable tubular shaped bright scarlet flowers. Oz., 30 ets... CONVOLVULUS. Brilliant climbing plants which transform window boxes, fences, etc., into mazes of color. Lovely anywhere, a few plants soon cover a large area ....................25 cts... CLEMATIS Paniculata. An invaluable climbing plant. Grows in one season 20 to 25 feet. Rapidly covers any trellis wall or in one season 20 to 25 feet. Rapidly covers any trellis wall or other object with a dense mass of small glossy green leaves, from
out of which during July till September shine the pure white flowers like so many stars.................................... ECHINOCYSTUS Lobata (Wild Cucumber). One of the quickest growing vines. The grandest thing for waste places, banks, "stone walls. Grows 20 to 25 feet in incredibly short time. The seed pods are highly ornamental. Soak the seed 24 hours in warm, not hot, water, before planting and plant it with the eye downwar.

Oz., 30 ets.
SEASHORE SEEDS. A mixture selected for those occupying their country or seaside places during the Summer and desiring a satisfactory display of flowers in their Summer gardens. These flowers
will thrive in salt air and sea fogs. Many sorts suitable for Pkt. will thrive in salt air and sea fogs. Many sorts suitable for
cutting have been included. This mixture will fill the need of many. cutting have been included. This mixture will fill the need of many. $1 / 2$ oz., 25 ets.; oz., 35 ets.; $1 / 41$ 1b., 85 ets...\$0.10 WILD FLOWERS. For beautifying at a minimum cost nothing approaches Wild Flower seed for effect and cheapness. For wood-
land walks, and wild gardens. All the sweet wild flowers included. Large pkt., 10 cts.; oz., 20 cts...

CLIMBING PLANT SEEDS-Continued

KUDZU VINE (Pueraria Thunbergi). This is the most remarkable Plt. rapid growing perennial vine in existence, and is unparalleled for ornament and shade............................ LINARIA Cymbalina (Kenilworth Ivy). Excellent for hanging baskets, vases, pots, old stone walls. Throughout the summer the
plant is covered with masses of dainty lilac and yellow flowers.! plant is covered with masses of dainty lilac and yellow flowers.

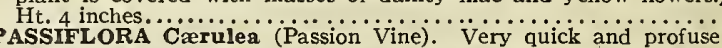
grower. Vines will run Io to 30 feet, and be covered with bloom...

\section{BEAUTIFUL IPOMOEAS}

Ipomoea Bona Nox (The Moon Flower). One of the grandest climbers, growing 25 to 30 feet high, covered nightly with white

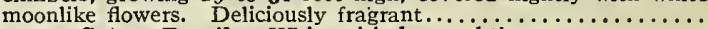

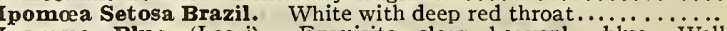

Ipomoea Blue (Leari). Exquisite clear heavenly blue. Well

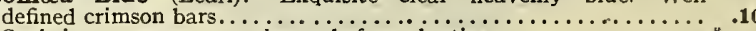

Soak in warm water 24 hours before planting.
randiflora Rosea. Same as White Moonflower, but the flowers

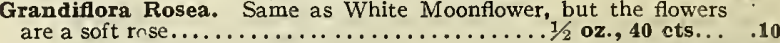

\section{JAPAN MORNING GLORIES}

MORNING GLORY Imperialis. These magnificent sorts of Morning Glories are getting to be known and every season the demand increases. We offer the very best.

Giant Variety. Flowers are five inches in diameter..........\$0.10

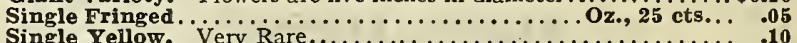

Single Yellow. Very Rare...
Best Double. Finest tints..Trial pkt., 10 cts.; oz., 40 cts......

Tokio Beautles. Miniature Morning Glories of ethereal beauty.

Exhibitions of these lovely flowers are held by the Japanese en-

thusiasts every season. Finest Prize exhibition blooms

Trial pkt., a lew seeds, 10 ets.

\section{OTHER JAPANESE SEEDS}

IRIS Kampferi. The most interesting new Hybrids can be raised from the Iris seed. It takes a little patience as the plant will not flower before the second year, but the results justify the waiting.

LOTUS (Nelumbium Speciosum). White or rose............... PRIMULA Japonica. Lovely variety of Primula. Large heads of flowers in rose to mauve tints............... Trial pkt., 10 ets... plant is very ornamental. The brilliant red flower is enclosed in a
plant plant is very ornamental. The brilliant red flower is enclosed in a
bright green outside set of petals giving the appearance of a light set inside a lantern. Of very easy growth..................... LILIUM Auratum. Try raising this from seed. " It will flower in two years. From actual results we know that bulbs raised from seed give astonishing results as to size of flowers and hardiness

PLATYCODON Mariesi (Japanese Bellflower). One of the best hardy perennials, producing large open bell-shaped flowers of a rich violet-blue. 


\section{SUMMER FLOWERING BULBS AND ROOTS}

Prices on this list of Bulbs and Tubers (except where noted), include free delivery by mail, express or freight. Write for "Special Prices" where larger quantities are desired.

\section{AMAR YLLIS}

More and ever more do these royal flowers gain favor with us. The demand has increased enormously in the last five years, and with those who have begun to cultivate these gorgeous flowers it has become a real craze. We are in a position to supply the very best in that line, marvels in size, coloring and profuseness of bloom.

\section{DIRECTIONS FOR PLANTING}

It is an accepted idea that Amaryllis are hard to grow, while in fact they are amongst the easiest flowers to bring to perfection. Plant as soon as bulbs are received, in a compost of two thirds good garden loam, adding one third of leaf mold and a small addition of sharp sand. Plant the bulb only one half below the surface, leaving the other end out of the soil. Give

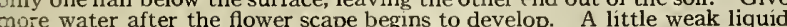
more water after the fower scape begins to develop. A little weak liquid

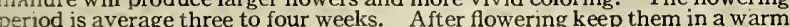
period is average three to four weeks. After fowering keep them in a warm lace and water freely until end of August, when water must be graduall into new soil any time after October first. Or they can be stored in dry material such as sand, Cocofiber, etc., and kept over in a frost proof place intil the following spring.

We offer a list of truly magnificent species.

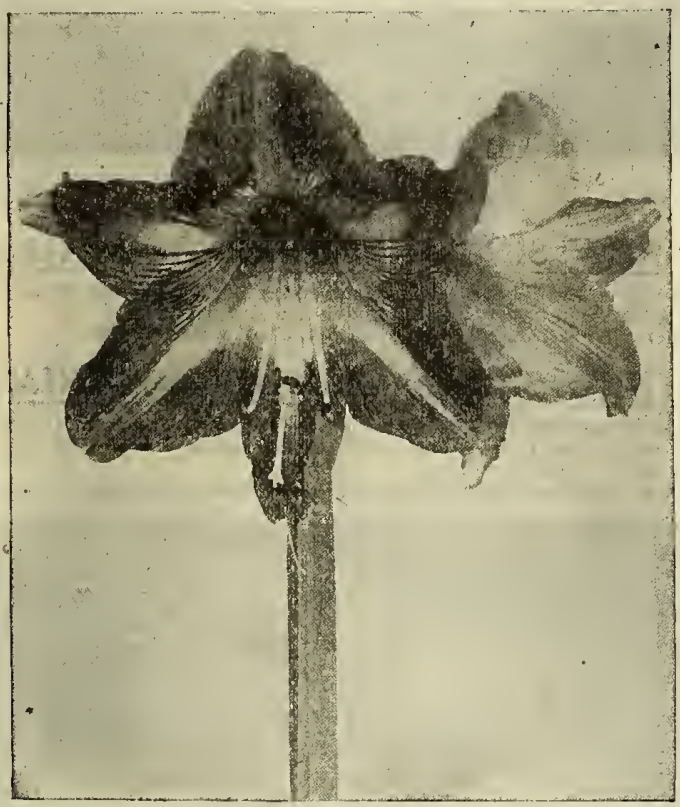

\section{NEW ROYAL AMARYLLIS}

This new race of Amaryllis produces a bulb of enormous size and strength, throwing up broad, healthy foliage and stout flower scapes, each producing blossoms of truly gigantic size. The flowers are often a foot or more across, larger than the Auratum Lily, and with colors which for purity and intensity are marvels. A well known specialist has spent years in hybridizing and are marvels. A well known specialist has spent years in hybridizing and perfecting this strain, during which time they have been seen by horticul-
tural experts all over the world, and their great superiority over all known tural experts all over the world, and their great superiority over all known maryllis fully acknowledged. The colors vary from as near pure white as has ever been found, to the deepest maroon, taking in all intermediate shades and showing contrasting stripes of white, rose scarlet, bloo

To have the best in Amaryllis give

Each bulb $\$ 1.00 ;$ s $1 x$ for $\$ 5$. seminate these floral wonders.

\section{GENERAL LIST OF AMARYLLIS}

A. Bella Donna. Flowers midsummer and fall. Stems Each Doz.

Aella Donna. Flowers midsummer and fall. Stems
$2 \frac{x}{2}$ to 3 feet high carrying from 6 to 12 flowers in umbels. $2 \frac{1}{2}$ to 3 feet high carrying from 6 to 12 flowers in umbels.

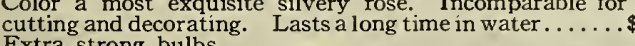
Extra strong bulbs $\cdots$ (Barbadoes Spice Lily). Bright Amaryllis Equestris (Barbadoes Spice Lily). Bright line through part of petals. Free bloomer and very showy. Extra strung bulbs

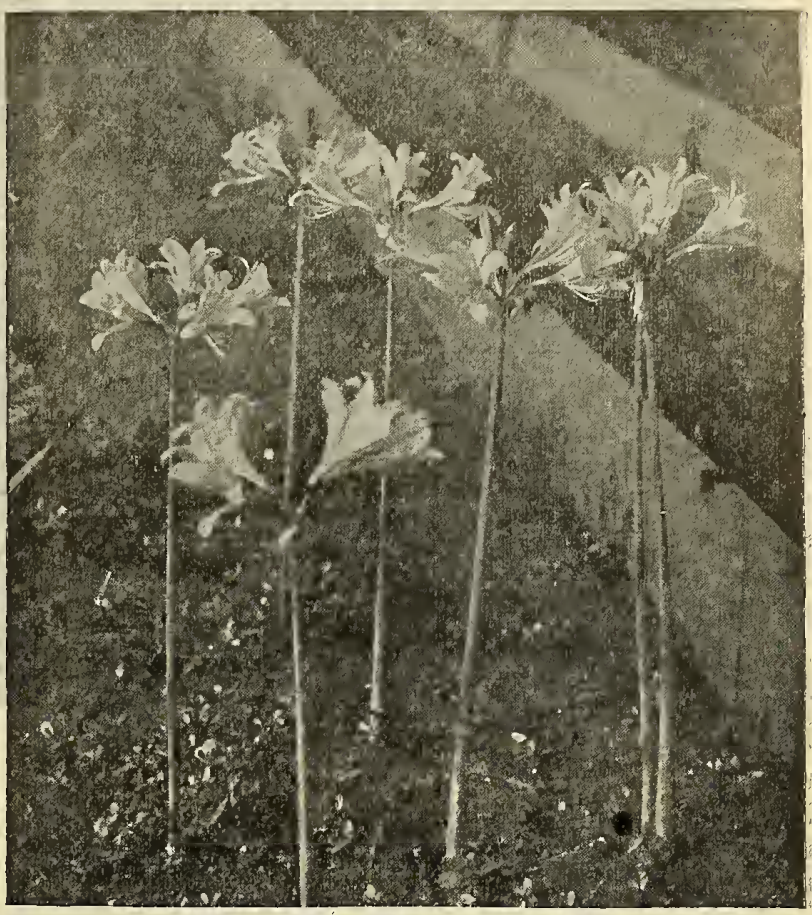

Amaryllis - Hallis

A. Hallii. (Japan Amaryllis or Lycoris.) Produces in early spring attractive green foliage, which grows until July when it ripens off and disappears, and everyone not familiar with the growth of the bulb, would think it had died, when, about a month later, as if by magic, the flower stalks spring up from the ground to a height of $2 \frac{1}{2}$ to 3 feet, developing umbels of large and beautiful lily like flowers, 3 to 4 inches across, and from 8 to 12 in number. Color a most delicate rosy mauve, shaded with clear blue. A color Each doz. most delicate rosy mauve, shaded with clear blue. A color Each doz.

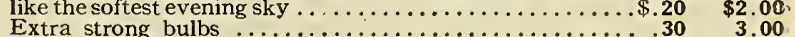

Note. As this bulb, contrary to other Amaryllis is perfectly hardy, it can be planted either fall or spring. Cover the crown 3 to 4 inches. This. Amaryllis is most beautiful in the herbaceous border among shrubbery or in groups.

A. Formossissima (St. Jacob's Lily). Very showy flower, of deepest scarlet. Can be grown in pebbles and water like a Hyacinth, and will give beautiful bloom in winter garden. Planted outdoors in the spring it will flower in summer

Extra large, strong bulbs

A. Johnsoni. A grand Amaryllis. Immense flowers of great substance. The color is an intense deep crimson scarlet, with a broad white stripe through each petal Bloom beautifully in the house in winter, or outdoors in summer. Large bulbs

Monstrous bulbs

A. Vallota Purpurea (Scarborough Lily). A most exquisite fall and winter flowering lily-like flower. Splendid for winter garden and pot culture. Produce strong, tall spikes of fiery scarlet flowers. Plant several bulbs in a receptacle 10 to 12 inches diameter, the gorgeous effect will receptacle 10 to 12 inches diameter, the gorgeous effect will effect is that of living, glowing flame

A. Nerine Sarniensis. A most beautiful species of Amaryllis like flowers. They succeed splendidly in the house, throwing up strong stems, 18 to 24 inches high, carrying umbels of richest glowing salmon-rose flowers

A. Nerine Japonica. This beautiful Nerine flowers in late fall from November to January. The flowers are a deep scarlet crimson, the anthers a lighter shade and the whole flower makes the effect of being frosted with silver. It sparkles in the sun or in artificial light. Small bulbs commence to flower, and last in bloom a long time.
$35 \quad 3.00$
$.40 \quad 4.00$ 


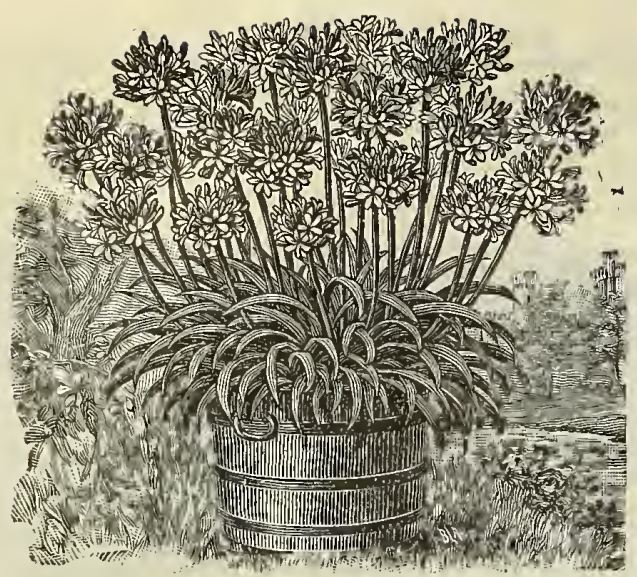

Agapanthus Umbellatus

\section{AGAPANTHUS UMBELLATUS}

(Blue African Lily.) One of the most showy and striking plants. The color is the most intense clear blue, so rare in flowers, the blossoms being carried on long stems in heavy umbels, as many as 12 to 15 flowers to each stalk. Unexcelled for planting in large 12 to 15 flowers to each stalk. to the tub. Make an ideal lawn, tubs or pots of several tuberation. These tubers can be planted with with great effect along running water. tubers must be lifted in October and stored in a dry cellar or frost proof place in dry sand when they can be replanted in spring. Tu-
bers in pots can be kept in pots or tubs in the cellar over winter or in any place where frost does not enter. Each 25 cts.; doz., $\$ 2.75$.

White form of Agapanthus Umbellatus. Beautiful white flowers slightly shaded blue. Each 30 cts.; doz., \$3.00.

\section{ANEMONES}

Beautiful spring and summer flowering plants, bearing both single and double flowers, and of a richness of coloring that is almost indescribable.

Coronaria, Single'Poppy flowered. Large beautiful saucer- Doz. 100 shaped flowers Magnificent mixed colors....

$20 \quad 1.50$

Coronaria (Double Poppy flowering). The flowers are very double, surrounded with large guard petals. The colors are of the greatest variety and gorgeousness. Several colors are usually blended in one flower like scarlet and purple, rose and lilac, white and red

Fulgens. Single rich, dazzling scarlet flowers on graceful stems. Especially fine for cutting, lasting a long time...

Giant St. Brigid's. A new Irish race, bearing profusely magnificent flowers, single, semi-double, and double, 3 to 5 inches across; of the richest tints, representing all known colors. You will see white, flesh color, rose, mauve, purple, bright scarlet, maroon, crimson, blue striped, zoned, flushed flowers, a floral rainbow. The flowers are born on long graceful stcms and the foliage is feathery bright green. Grow in the house or over winter in a coldframe to olant cut in spring or plant in the ground in sheltered spots well protected. They are a show of gorgeous colors wherever grown Large bulbs ...........................

\section{TUBEROUS BEGONIAS}

One of the most valuable bulbous plants for Lawns in beds, or borders. The only gay and brilliant colored flower, that will thrive and blossom in absolute shady places While they bloom fine in the sunshine they gain an additional lustre of tints in the shade. The gigangic waxy flowers are borne on long stout stems well above the beautiful foliage. Begonias are of the easiest culture, rarely attacked by either blight or insects. For very early bloom start the bulbs in the house in February to March in flats in a light soil composed of $\frac{1}{3}$ good fine soil and $\frac{1}{3}$ leafmold with a little admixture of sand. (We have started Begonias and Gloxinias with great success in our prepared Mossfibre). Plant in flats 2 inches apart and take great care that in planting you place the depressed or germ end upward. The smooth round side produces the roots. The soil or Mossfiber must be kept slightly moist and the whole kept in a warm place near the light. As soon as warm weather is settled lift the young plants carefully and set in permanent beds. Or plant the bulbs directly in the open when no more danger of frosts threatens.

Begonias prefer situations where no high winds strike them. If planted in full sun keep the ground moderately moist.

\section{SINGLE FLOWERING VARIETIES}

In separate colors.

White, scarlet, crimson, blush rose, deep rose, yellow, orange.

Large bulbs in any of these colors: 3,20 cts.; doz., 60 cts.; $100, \$ 5.00$. Mixed colors: 3,15 cts.; doz., 50 cts.; $100, \$ 4.00$.

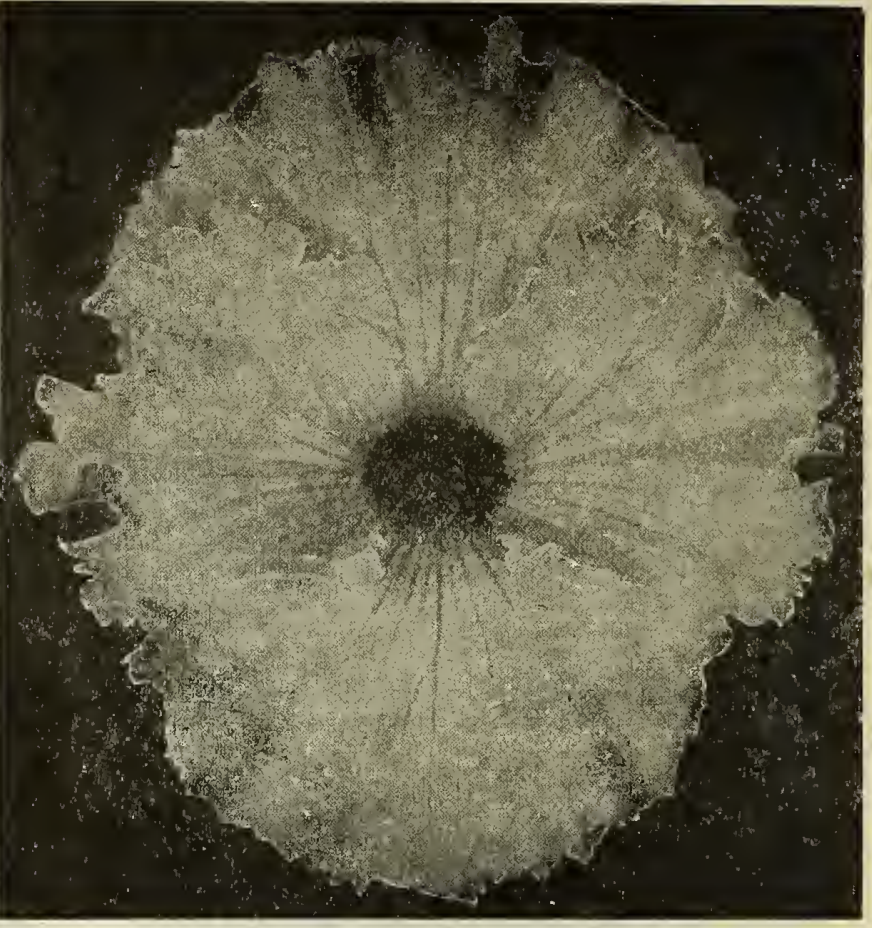

Ruffled Single Begonias

\section{NEW SINGLE FRILLED BEGONIAS}

In this new and beautiful race the flowers are immense, borne on mas sive stems, each flower charmingly ruffled and frilled.

Each, 15 cts.; three, 40 cts.; doz., $\$ 1.25$; $100, \$ 10.00$.

\section{NEW SINGLE CRESTED BEGONIAS}

The flowers are ruffled and frilled like Giant Petunias or Orchids, and each petal crested or bearded as found in Bearded Iris. The colors are same as in single Begonias.

Each, 12 cts.; three, 30 cts.; doz., $\$ 1.00 ; 100, \$ 8.00$

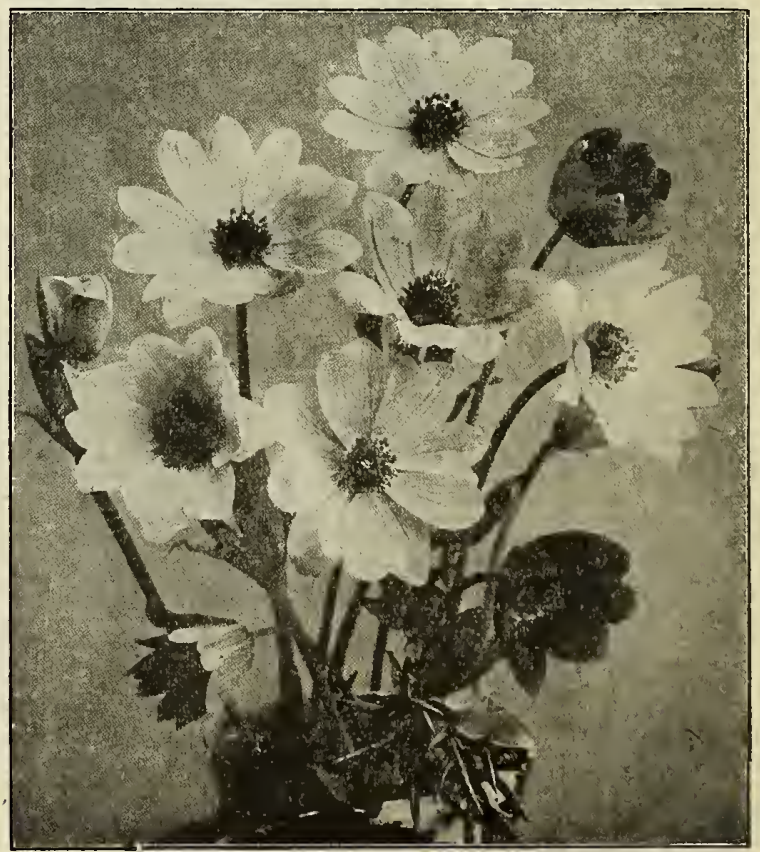

Anemone St. Brigid's 


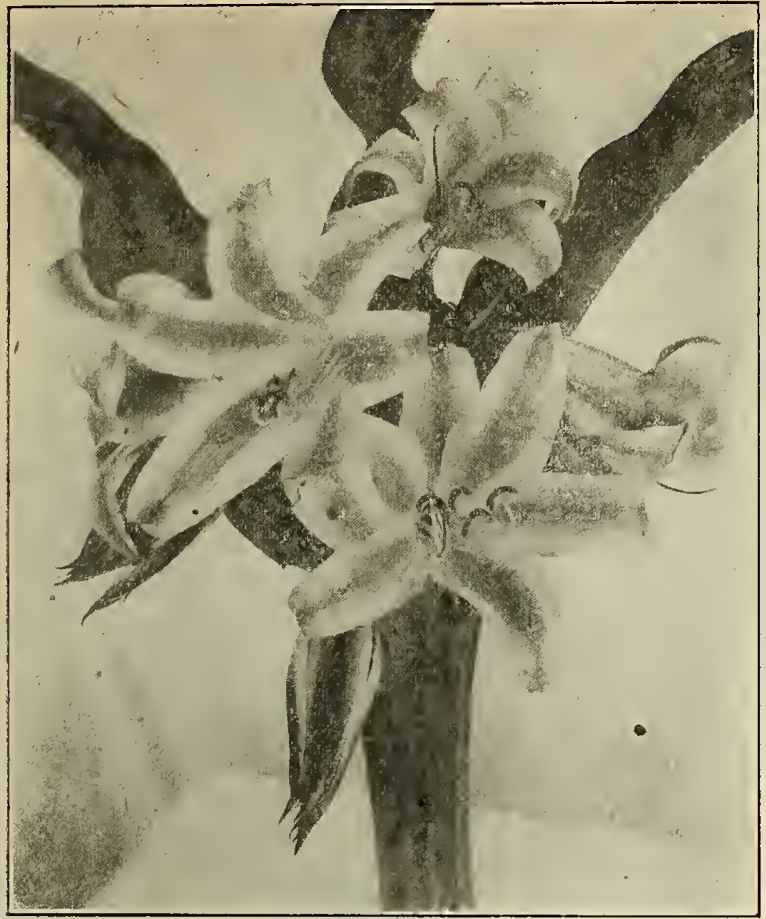

\section{GORGEOUS CRINUMS}

This grand new plant forms large, imposing clumps that are a mass of clustered heads of fragrant flowers. The flowers bave a peculiar and striking beauty which must be seen to be appreciated. More beautiful than most of the high-priced Lilies. An extra choice garden flower which we cannot too strongly recommend. Also a fine pot plant.

Fimbriatulum (Milk and Wine Lily). A strong grower, not particular as to soil. Flowers in umbels; very large and showy, striped white and crimson; 3 to 4 inches in diameter. Exceedingly choice and desirable as a pot plant or bedding out during summer. The fragrant flowers produce a sensation when seen. Each, 40 cts.; 3 for $\$ 1.10$, postpaid.

Kirki. This produces a large, round bulb, which grows to weigh as much as ten pounds. It is of the easiest culture, and sure to succeed with everyone. Its flowers are large, and like a most beautiful Lily, borne in immense clusters at the top of the stout scapes. Color, sof delicate blush, with a scarlet bar through the center of each petal, and very sweet scented. Each, 50 cts.; 3 for $\$ 1.35$ postpaid.

Ornatum. Very rare and supremely beautiful. Flowers of immense size, almost as large as an Auratum Lily. Color pure white, with a deep band of brightest, richest crimson through center of eacb petal. Orchids only can equal tbis flower in supreme beauty and contrast of coloring. Flowers very fragrant and borne in great clusters. Strong bulbs. Each 60 cts., postpaid.

Powelli Rosea. Flowers borne in large fine clusters, and are exceedingly beautiful and fragrant. Color a most delicate yet bright and beautifu pink. It possesses a degree of loveliness which cannot be described Fine bulbs. Each, 50 cts.

Powelli Alba. White. Like the above but pure white. There is no grander flower than this ever bloomed. No Lily can exc:l it in regal beauty and fragrance. Each, 50 cts.

One each-5 "Gorgeous Crinum" postpaid, \$2.25.

\section{BESSERA ELEGANS}

The Mexican Coral Drop. A charming coral red bell-like flower which drops from its many branches like a dainty bell. Height 12 to 15 inches, flowering profusely in Summer, this pretty plant is pleasing to the eye wherever seen. The bulbs must be taken up in late Fall, same as Begonias. Large bulbs sure to flower. Each, 5 cts.; doz., 50 cts.; per $100, \$ 2.50$.

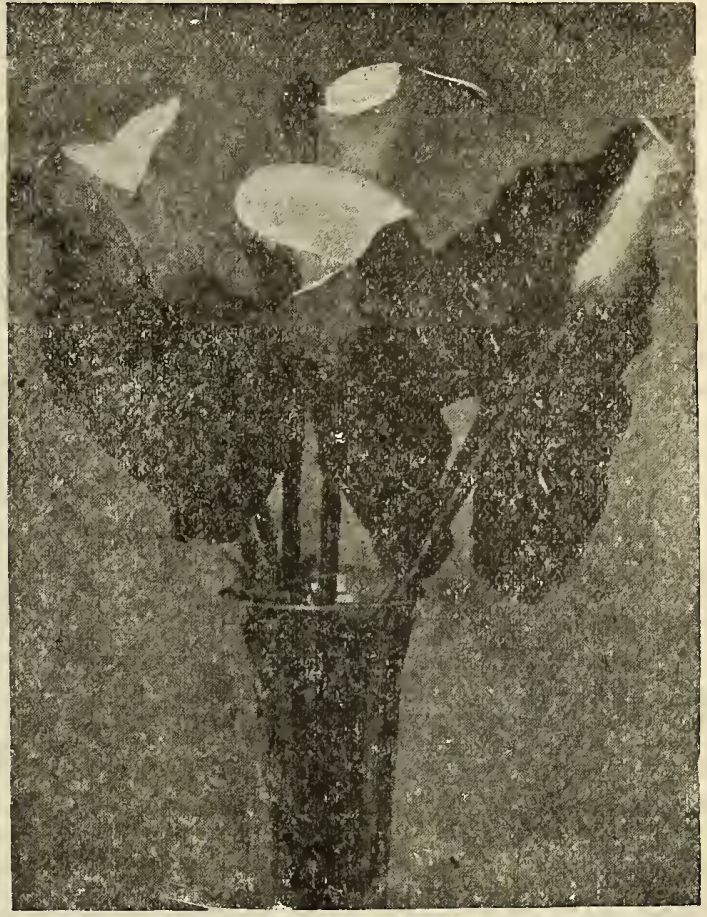

\section{CALLAS FOR SUMMER BLOOM}

These are grand bulbous plants alike beautiful in beds or pots. The These are grand bulbous plants alike beautiful in beds or pots. The
colors are many and varied. Thrive anywhere, given good soil and a colors are many and varied. Thrive anywhere, given good soil and a
good supply of moisture. When in bud an application of weak liquid good supply of moisture. When in bud an application of weak
manure will give the flowers greater size and brilliancy of coloring.

Aurata (Lemon Calla) ${ }^{*} \mathrm{New}$ and fine, the flowers being a beautiful light yellow, with a jet black center, therefore very conspicuous and showy. Its foliage is large and handsome, deep green, freely spotted white. Makes a most superb pot plant. Each, 25 cts.; doz., \$2.75.

Calla Elliottiana. The finest yellow Calla, of a deep rich golden yellow color with large flowers, 4 to 5 inches across; foliage spotted with silvery white. A free bloomer and easily forced in the house; exquisite. Each, 30 cts.; doz., $\$ 3.00$.

Godfreyana. A superb novelty in Callas. Dwarfer in type with all the beauty of the taller growing species. It is exceedingly free blooming, the blossoms being of the purest glistening showy whiteness. Each, 25 cts.; doz., $\$ 2.50$.

Mrs. Roosevelt. Flowers light clear yellow, produced freely on long stems. Foliage, deep rich green, distinctly and freely blotched with white, making the plant very effective for banking and other forms of decorations, and more distinct and showy than Fancy Caladiums for many purposes. It does well planted outside, grows strong and flowers many purposes. It does well planted outside, grows strong and flowers
freely. Probably the best Calla for this purpose extant. Extra large freely. Probably the best

Rhemanni (Pink). This magnificent new Calla has a large flower of a rich deep shade of pink that is perfectly exquisite. A strong, easy grower, and a free bloomer. Each, 35 cts.; doz., \$3.50.

Ricardia Maculata. Spotted Leaved Calla. Dark glossy green foliage spotted silvery white; flowers.same as the C. Athiopica; habit somewhat smaller. Each, 15 cts.; doz., \$1.00.

One each of above six sorts of beautiful Callas which in bloom form a unique decoration, $\$$ I.50. Three of any kind at dozen rates. Delivery included in price.

\section{CHILDANTHUS FRAGRANS}

The blooming of this new bulb with us last season was a revelation oflbeauty. It is much like an Amaryllis, with a strong bulb, which starts of! beauty. It is much like an Amaryllis, with a strong bulb, which starts 4 to 6 , and are in color the brightest golden yellow, and such fragrance. 4 to 6 , and are in color the brightest golden yellow, and such fragrance, Strong and delicious without being in any way rank or offensive as is th case with many highly scented flowers. Two or three spikes of these exquisite large yellow blossoms are produced at each blooming period. Pot the bulbs at any time, winter or spring, and they will soon be in bloom. A trulv magnificent thing. Strong bulbs. Each, 10 cts.; 3 for 25 cts. doz., 85 cts.

WE DO NOT PREPAY ONFROTS, UNLESS ESPECIALLY NOTED 


\section{DAHLIAS}

The Dahlia, so long a rather neglected flower, has come into its own, and finds more and more favor in the eyes of all flower-lovers. Alongside of the old and tried favorites new sorts have sprung up through hybridizing, but up to now the Glory-of-Autumn gardens has shown that many of the old fashioned varieties are still leading the van. So much depends on the culture of these beautiful flowers that we add a few words about their care. Culture-Dahlias prefer a rather poor soil, but an oren sunny situation is absolutely requisite. Allow $3 \mathrm{ft}$. of space between each plant, to afford room for expansion. Use no manure as fertilizer and never set the roots out until all and every danger of frost is past. As soon as the plants are 6 to 8 ins. high, give the main stem a support, to which it must be carefully tied. After the buds begin to form it is most beneficial to feed the roo from the surface by spreading well rotted manure over the ground.

\section{MAGNIFICENT TYPES OF DAHLIAS-- SHOW, DECORATIVE and FANCY}

Belle Inconstant (Dec.). Pure yellow, striped and suffused scarlet, sometimes showing white tips Very free flowering.

Black Beauty (Show). Velvety purple maroon.

Caleb Powers (Show). Delicious shell pink. Large flower, long stems. splendid for cutting.

Catherine Duer (Dec.). Vivid scarlet; one of the most decorative shades in decorative Dahlias. Flowers very large, of fine form. A great favorite.

Cuban Giant (Show). Dark reddish maroon. Immense flowers, 6 ins. across, stands erect on very long stems well above the foliage.

Delighted (Show). One of the finest and largest show sorts in existence. Double flowers, 6 to 8 ins. across, snow white.

Dorothy Peacock (Sbow). Very large flower, exquisite form, great substance; color, a clear live pink, appealing to everyone.

Emily (Show). Delicate lavender; long, stiff stems. Extra fine.

Eventide (Dec.). A splendid flower of perfect form; may be termed a White Dahlia, there being but the faintest flush of pale rose on the edge of the petals, thereby accentuating its splendid purity.

Ruby Queen (Show). Ruby red, richly shaded; well known.

Gaiety (Fancy). Bright strawberry red, eacb petal having a broad band of white through tbe centre.

Jack Rose (Dec.). Brilliant crimson red, similar in shade to the popular Jack Rose. Perfect form and habit.

Mina Burgle (Dec.). A champion variety, producing flowers of gigantic size and remarkable beauty. Glowing, dazzling scarlet blooms, on long, wiry stems.

Nymphea (Show). A broad petaled variety, in form much like-a water lily. Color, flesh shading to soft rosy white. Lovely as its name.

Sunset (Dec.). A rich, old gold, the most striking rich yellow shade found in Dahlias.

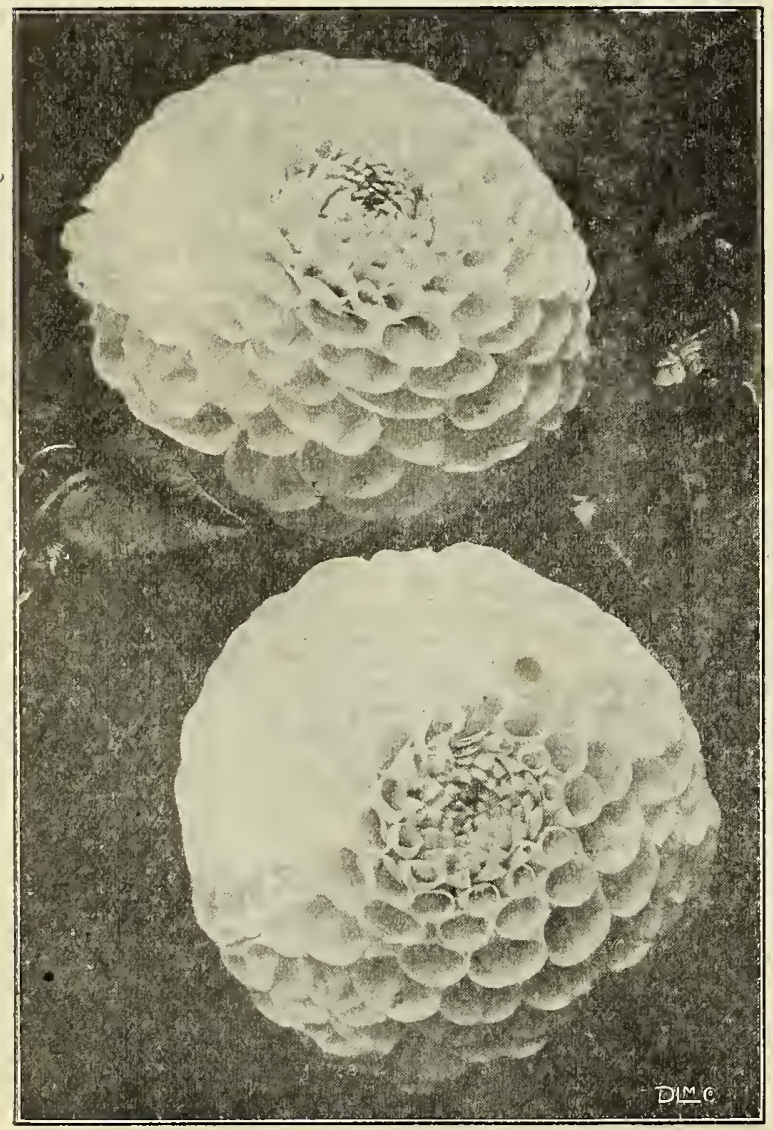

Show Dahlias

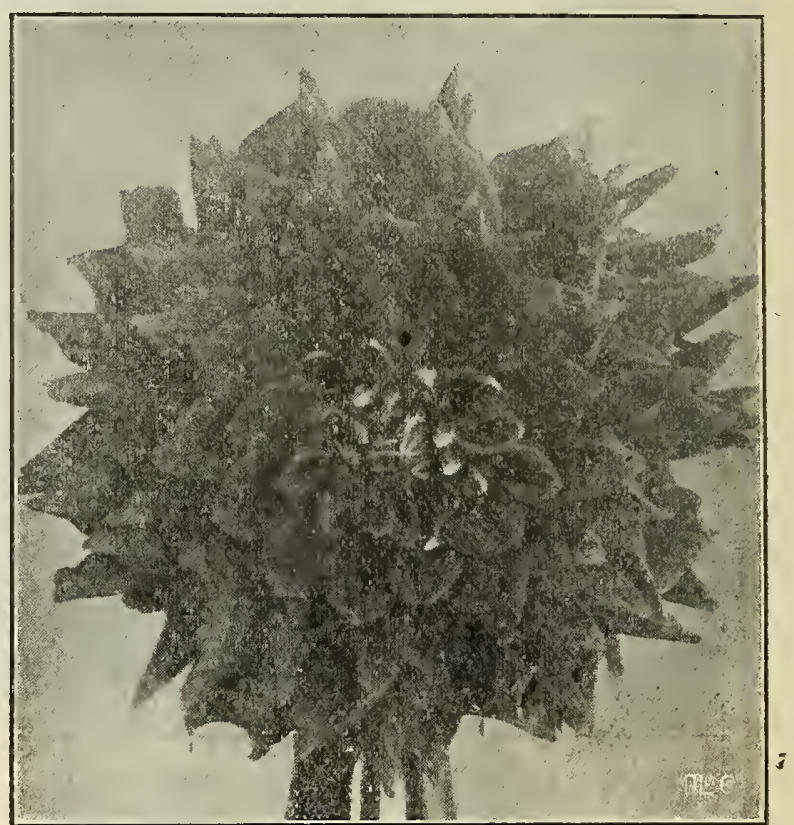

Decorative Dahlia

Sylvia (Dec.). Deepest pink shading to flesh pink at heart. A beauty for cultivating.

Oregon (Dec.). A gorgeous flower attracting attention on account of its rich coloring. Intense oriental red witb a golden sheen and garnet suffusion. Flowers in greatest profusion.
A. D. Livoni (Show). One of the best old favorites; delicate pink flowers on long stems; exquisite for cutting

Perle de la Tete d'Or. Snow white flowers on long stiff stems." Tbey present a beautiful feathery appearance. Resemble closely a Pæony Very double and free blooming.

\section{Each, 25 cts.; doz., \$2.75.}

\section{BEST CACTUS DAHLIAS}

Cattleya. Deep lavender pink, resembling an Orchid; beautiful form. Cockatoo. A most beautiful and interesting variety. Clear yellow tinted Cockatoo. A most bea.

Countess of Lonsdale. Salmon pink and amber; a shade difficult to describe. Blooms freely under all conditions. Dainty. Described by its name. The dainty coloring baffles description. Best described as a lemon base shading into rosy pink tips. A beatuty. Duchess of Marlborough. A magnificent variety in habit of growth freedom of bloom and perfection of flower. Solferino red florets suffused golden at the heart.

Firelight. Bright Indian red grading into sbades of yellow. Flowers early and most profusely till frost.

Gaillard. Bright vermilion with long slender petals.

Golden Gate. A dazzling yellow of immense size. This grand Dahlia surpasses any of its color in flowering qualities.

Libelle. Flowers very large, of perfect form. A beautiful'mauve" lilac. Florets narrow and perfectly incurved.

Mrs. H. E. Collins. Pure salmon pink. A new and unusual shade in Dahlias. Vivid yet delicate. Flowers of giant size, long florets curving forward.

Perle de Lyon. An immense pure white. Tbe blooms are perfectly globular, the petals incurving and cleft at the tips. Plants stand_erect. and have long wiry stems.

Pink Pearl. Amber pink at base of petals shading off "to the tips, "the effect being a soft rosy pink. Exquisite for cutting.

Prima Donna. Flowers very large, ivory white tinged with violet. Florets twisting and interlacing, resembling a Japanese Chrysanthemum. Florets twisting and interlacing, resembling a Japanese
Vigorous grower, flowers rising well above tbe foliage.

Rhine-Koenig. Pure snow white flowers of exquisite form, 5 ins." and over in diameter, of great substance, lasting splendidly when cut; long stiff stems held well above the foliage. One of the finest Cactus Dahlias. Ruth Forbes. A wonderful Dahlia. Flowers clear rose pink. Extra stout stems, often $3 \mathrm{ft}$. long. It excels any variety for vases and decorations.

Starfish. Fiery scarlet, large finely formed flowers.

Each tuber, 25 cts.; doz., $\$ 2.75$ 


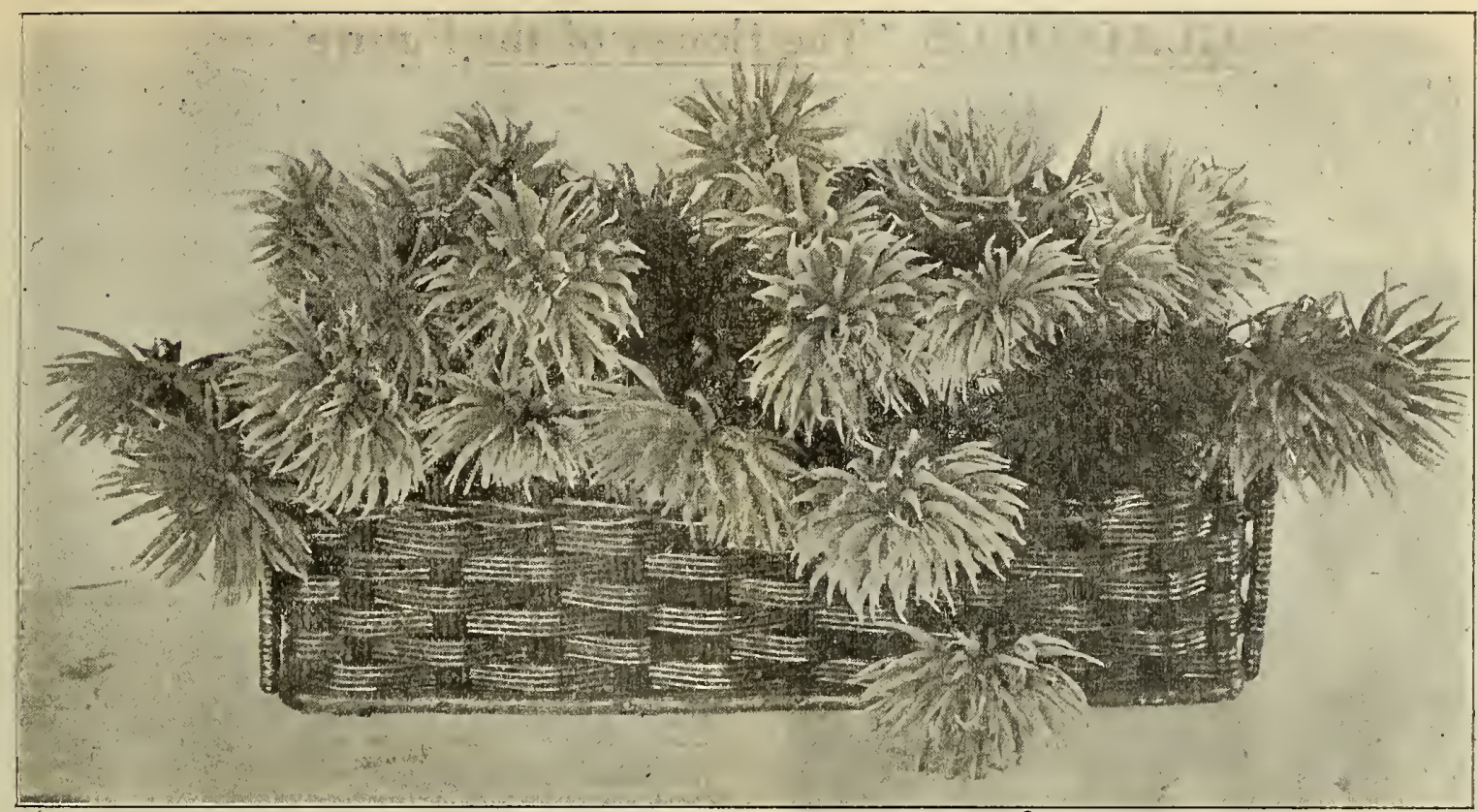

Basket of Cactus Dahlias-See paye 46

\section{PAEONIA FLOWERED DAHLIAS}

Glory-of-Baarn. Exquisite coloring; a charming clear pink forming a delightful contrast to the deep green foliage.

Loveliness. Pale lilac, shaded mauve with pink edges. One of the finest of its class.

Mrs. Jos. Chamberlain. A magnificent old rose shade of compact sturdy growth and very floriferous.

10.

Painted Lady. Color a most delicate and pleasing pale rose; a graceful flower of elegantly curved and twisted petals

Queen Wilhelmina. Immense fluffy flowers of pure white, with yellow center. Used much for decoration.

Dwarf Pæony Dahlia. Yellow transparent. A gem for bedding. Zeppelin. Velvety mauve; perfect form.

\section{POMPON DAHLIAS}

Almyn. Delicate rose, tinted lilac. Brunette. Crimson blenting into white. Exceptionally!beautiful.
Cheerfulness. Old gold, tipped scarlet.

Darkest-of-All. The name describes it fully. Blackishmaroon; Zvery beautiful.

Goiden Beauty. A most perfect golden yellow.

Salut. One of the finest shaped Pompons ever offered. Color"a"charming crushed strawberry. A very strong grower.

a.

Lassie. Yellow edged and tipped rose.

Little Beauty. Delicate shrimp pink, full round form, quilled petals. Midget. A beauty. Salmon shaded rose.

Neatness. Pale fawn color with edges just tipped with lilac. $\$$ Neatness and sweetness personified.

Sunshine. Richest vermilion scarlet. Splendid compact flowers onlong stems.

Each, 25;cts.; doz., $\$ 2.75$

\section{DAHLIA NOVELTIES}

Avalanche. The most magnificent pure snow-white Pæonia ] flowering

variety.
Xellow Prince (Show), Best yellow Show Dahlia to date.

Xellow Prince (Show), Best yellow Show Dahlia to date.
Dulke of Brunswick. Pronia flowered. Immense bright red with Dulke of Brunswick. Pronia flow
outside of the florets soft apricot.

Evening Star (Cactus). One of the most beautiful Autumn tint varieties; bright terra cotta with golden centre.

Fleuriste Bizet (Cactus). Imported French. Petals white bordered rich blood red. The points are finely serrated giving the flower a unique fluffy appearance, much like a huge Carnation.

Minnehaha (Dec.). Extra fine flat petals. Flowering a golden_bronze color. A most beautiful Dahlia.

Mrs. J. B. Chaffrey. A grand Cactus variety. A deep rich rose pink. Flowers abundantly all season. Invaluable for cutting.

Papa Charmet (Dec.). A magnificent variety of a deep velvety coral red, overlaid with a darker shade. A wonder.

Salvator. Pronia flowered. Deep rose pink long stems. Very rich

Souvenir de G. Douzan (Dec.). A rich fiery red that seems almost burnished. Petals of great width overlapping each other regularly.
buth

Virian (Show). An excellent flower. Centre Jacqueminot shade, inside of petals much lighter cerise.

Wotan (Cactus). Immense flowers, 6 to 7 ins. diameter. Florets curved and whorled. Delicate salmon rose color shading to old rose. Exceptionally attractive.

Each 50 cts. One of each 12 varieties $\$ 5.00$

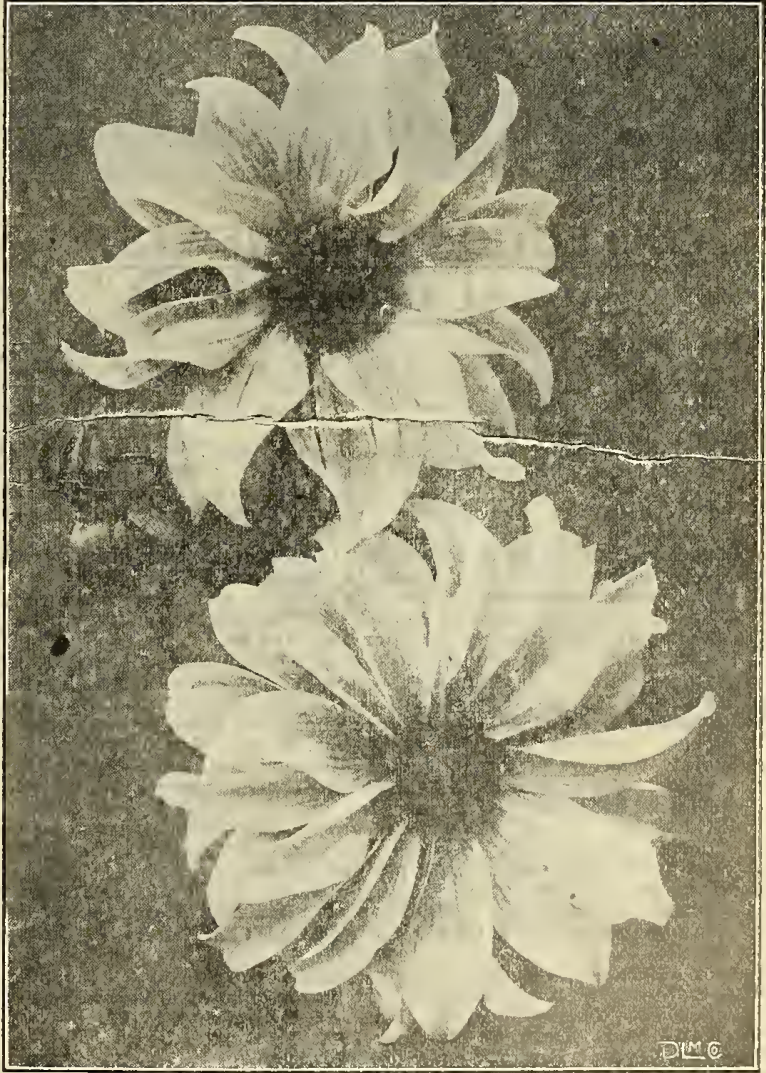

Paeonia Flowered Dahlia 


\section{GLADIOLUS "The flower of the Future"}

The Gladiolus is one of the few bulbs which will succeed in almost any kind of soil, provided the situation is a sunny one and the soil well drained. Before spading plant unil plant until the bulbs. Water freely, but always after sundown, and culti-

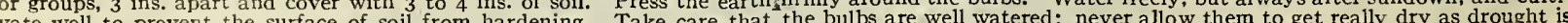

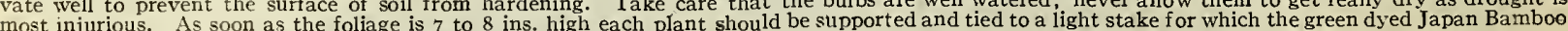
most injurious. As soon as the foliage is 7 to 8 in
are especially adapted. (See our offers page 64. )

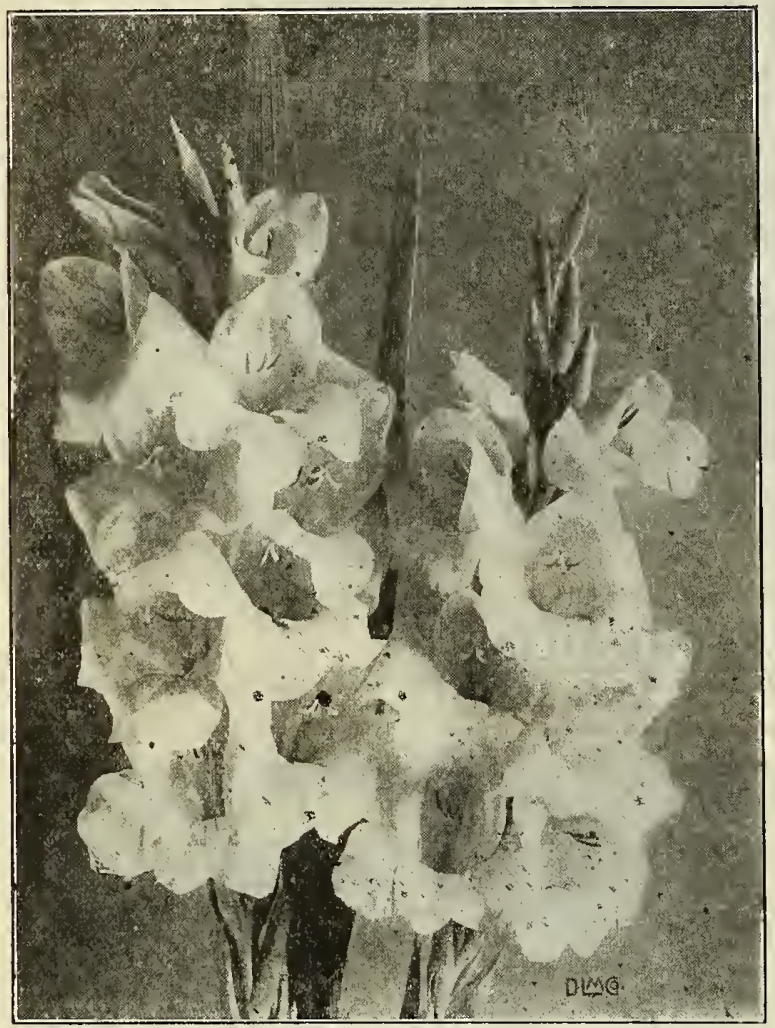

\section{COLLECTION of the NEWEST GLADIOLI}

1. Baron Hulot. The only true blue Gladiolus in existence. Rich, deep, clear indigo blue. Each, 10 cts.; doz., $\$ 1.00$; per $100, \$ 5.00$.

2. Fire King. Immense blooms on long graceful spikes. Intense fiery scarlet, of a most dazzling tint. A living flame. Each, 20 ets. doz., $\$ 2.00 ;$ per $\mathbf{1 0 0}, \$ 10.00$

3. Kunderdi Glory. Broad, expanded, wide open flowers; each peta is exquisitely ruffled and fluted at the edges. Straight stout stems, $31 / 2 \mathrm{ft}$. high. Color delicate cream pink with a crimson stripe in $31 / 2 \mathrm{ft}$. high. Color delicate cream pink with a crimson stripe in
the center of each lower petal. Each, 10 cts.; doz., 75 cts.; per $\mathbf{1 0 0}, \$ 5.00$.

4. Morning Star. One of the earliest to bloom. Snowy white with a velvety crimson throat. Each, 15 cts.; doz., \$1.25.

5. Mrs. Erank Pendleton. A striking novelty; orchid-like and lovely. Lovely salmon pink with deep blood red blotches in the throat. Each. 15 cts.; doz., $\$ 1.75$; per 100, $\$ 10.00$

6. Dawn. One of the grandest rose pink Gladioli ever offered. Long graceful spikes of magnificently formed flowers. Each, 15 cts. doz., $\$ 1.75 ;$ per $100, \$ 10.00$.

7. Lavender Queen. A marvelous blending of lavender and mauve tints. Entirely new coloring. Elending of lavender and

8. Viola. An exquisite mauve blue gradually shading into violet at the edges, throat toned soft canary with purple garnet blotch. Each, 20 cts.; doz., \$2.00.

9. Wild Rose. Stands alone in its lovely tint of blush rose. Large flowers of the most delicate rose tints imaginable. Exquisite. Each, 12 ets.; doz., \$1.25; per $100, \$ 7.00$.

10. Niagara. Delicate cream blending to canary yellow. The throat is splashed with carmine. Each, 15 cts.; doz., \$1.25; per 100, \$7.50. One each of the ten GLADIOLUS BEAUTIES listed, 10 Bulbs, $\$ 1.35$.

Ircelsior Mixture. Consists of many of the named varieties. Lemoine Kunderdi, etc. Carefully selected, and mixed in proper proportions of color to please the most critical. Doz., \$1.00; per 100, $\$ 7.50$.

Scarlet and Red. Doz., 40 cts.; per 100 , \$2.50.

White and Light. Doz., 40 cts.; per $100, \$ 2.75$

Striped and Variegated. Doz., 50 cts.; per $100, \$ 4.00$.

\section{LIST of MOST POPULAR and FAVORITE GLADIOLI}

America. One of the most vigorous and easily grown Gladioli known. Flowers of immense size, of the most exquisite lavender pink. Indispensable for cutting and bedding. Each, 5 cts.; doz., 40 ets.; per 100 $\$ 2.50$.

Attraction. Deep dark rich crimson with a very conspicuous large pure white center and throat. Really beautiful. Each, 6 cts.; doz., 50 cts.; per 100. $\$ 3.00$.

Augusta. Pure white with blue anthers. A lovely inexpensive sort Each, 5 cts.; doz., 50 cts.; per $100 \$ 2.50$.

Brenchleyensis. Vermilion scarlet. Large flowers. A most showy and satisfactory variety. Each, 5 cts.; doz., 35 cts.; per[100, $\$ 2.00$. Canary Bird. One of the best clear yellows. Planted together with blue sorts it is indeed enchanting. Each, 10 ets.; $10 z ., \$ 1.60 ;$ per $100, \$ 8.00$.

Halley. Delicate salmon pink with roseate tinge, the lower petals bearing a creamy blotch with a stripe of bright red, through the center, the whole producing a delightful effect Each, 5 cts.; doz., 50 cts.; per 100, $\$ 3.50$

Mrs. Francis King. One of the greatest favorites. Strong grower vigorous and healthy. Color brilliant vermilion scarlet. Flowers enormous $41 / 2$ to 5 ins. across, 5 or six usually expanded at one time. It is a beautiful show in the garden and splendid for cutting. Each, 5 cts.; doz., 50 cts.; per $100, \$ 3.50$.

Peace. Flowers are large, of perfect form on a heavy straight spike. Pure white, feathered with pale lilac Each, 5 cts.; doz., 50 cts.; 5 per 100, $\$ 3.00$.

May. Lovely pure white flaked crimson, Fach, 6 cts.; doz., 60 cts.; per $100, \$ 4.00$.

Princess. Rich crimson with broad white blotches across lower petals Immense flowers under cultivation, as large as an Amaryllis. Each, 10 ets.; doz., 75 cts.; per $100, \$ 5.00$.

Shakespeare. White lightly suffused with carmine rose. Each, $6^{\text {r }}$ cts.; doz., 60 ets.; per $100, \$ 4.00$.

Snow King. Pure sparkling white, retaining its purity in all kinds of weather. Each, 10 cts.; doz., 85 cts.; per $100, \$ 4.50$.

Scribe. Enormous flowers well opened on enormous spikes. White freely striped carmine. Each, 10 cts.; doz., 85 ets.; per 100, \$5.00.

Taconlc. Vivid rose pink with crimson blotch at edge. Each, 6 cts. doz., 75 ets.; per $100, \$ 4.00$.

Primulinus Hybrids. Most artistic and lovely in coloring, ranging from sulphur to chrome yellow and orange. Invaluable as cut flowers. No garden should miss them. Each, 10 cts.; doz., 75 ets.; per 100, $\$ 4.00$.

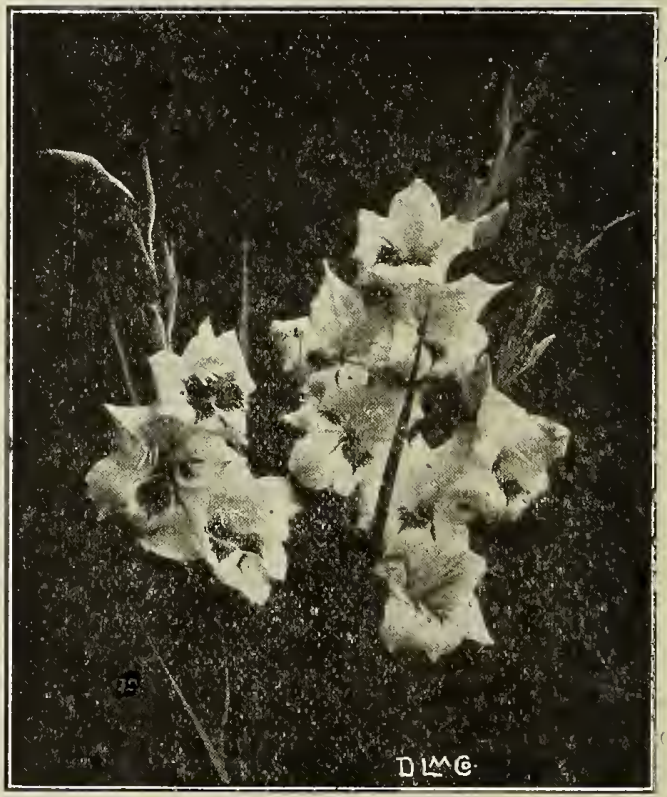

American Hybrids. All colors mixed. Doz., 25 ets.; per 100, \$2.00. Lemoine's Spotted Hybrids Mixed. Popularly known as Butterfly Gladioli. Remarkable for the richness and variety of their colorstand odd orchid-like markings. Doz., 30 cts.; per $100, \$ 2.00$.

Orange and $Y$ ellow. Doz., 75 ets.; per 100, $\$ 5.00$.

Pink and Rose Shades. Doz., 40 ets.; per 100, $\$ 2.50$. 


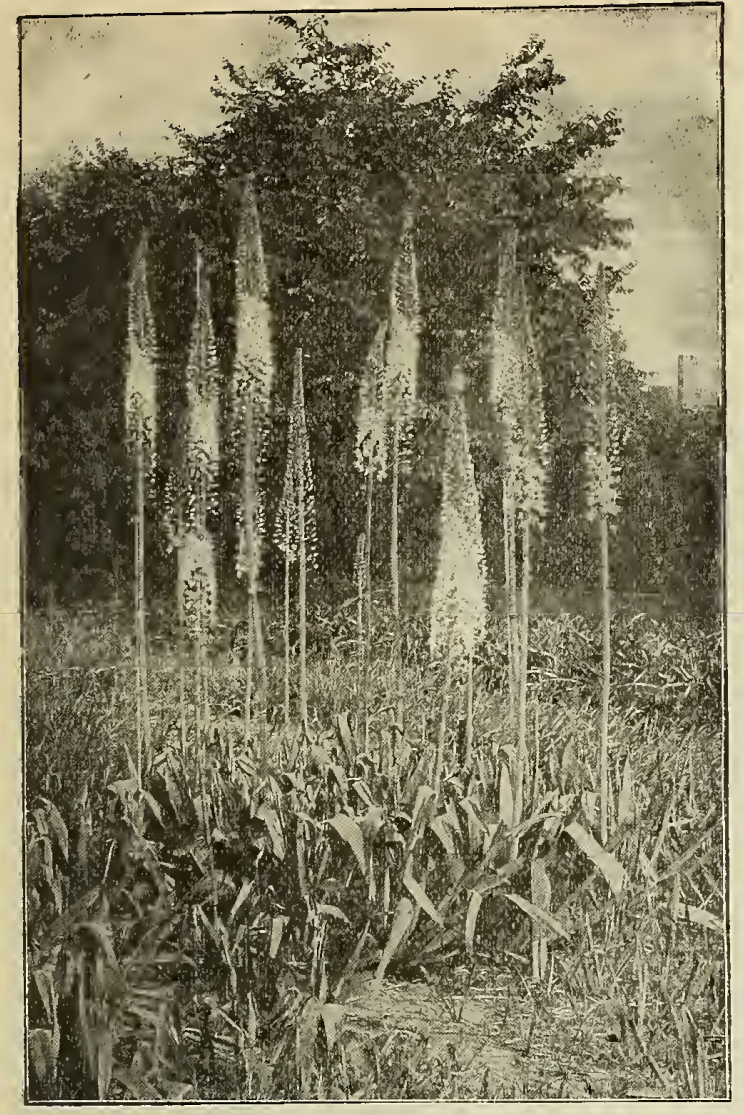

\section{EREMURUS}

A majestic plant. A rare ornament for garden and lawn. The flowers are closely set around a stem 7 to 8 feet in height, delightfully fragrant, and form a veritable giant fountain of bloom during June and July. Plant the tubers, 8 to 9 inches deep in a sunny, if possible somewhat sheltered, position. While the plant is hardy it is good to protect in winter, especially in very northern latitudes, with straw, hay, or leaves, 5 to 6 inches deep. We offer extra strong tubers which will flower first season. Price, $\$ 1.25$ each.

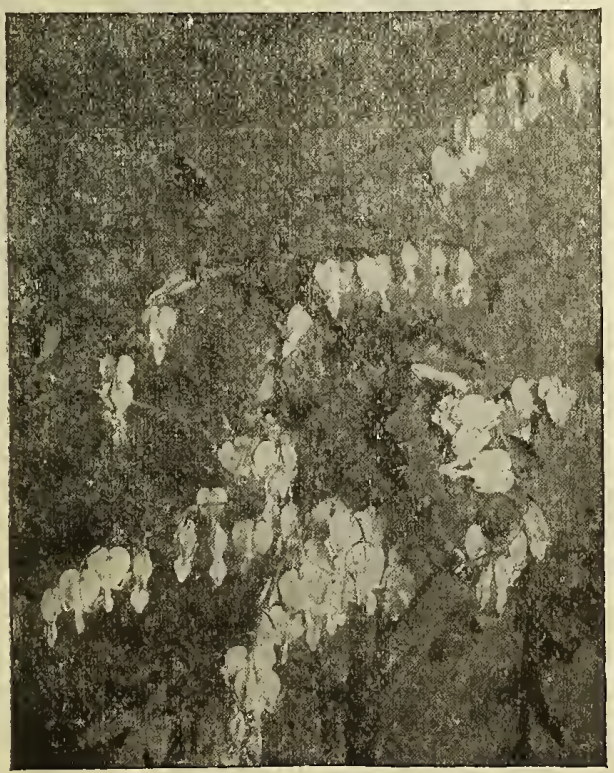

Dielytra Spectabilis

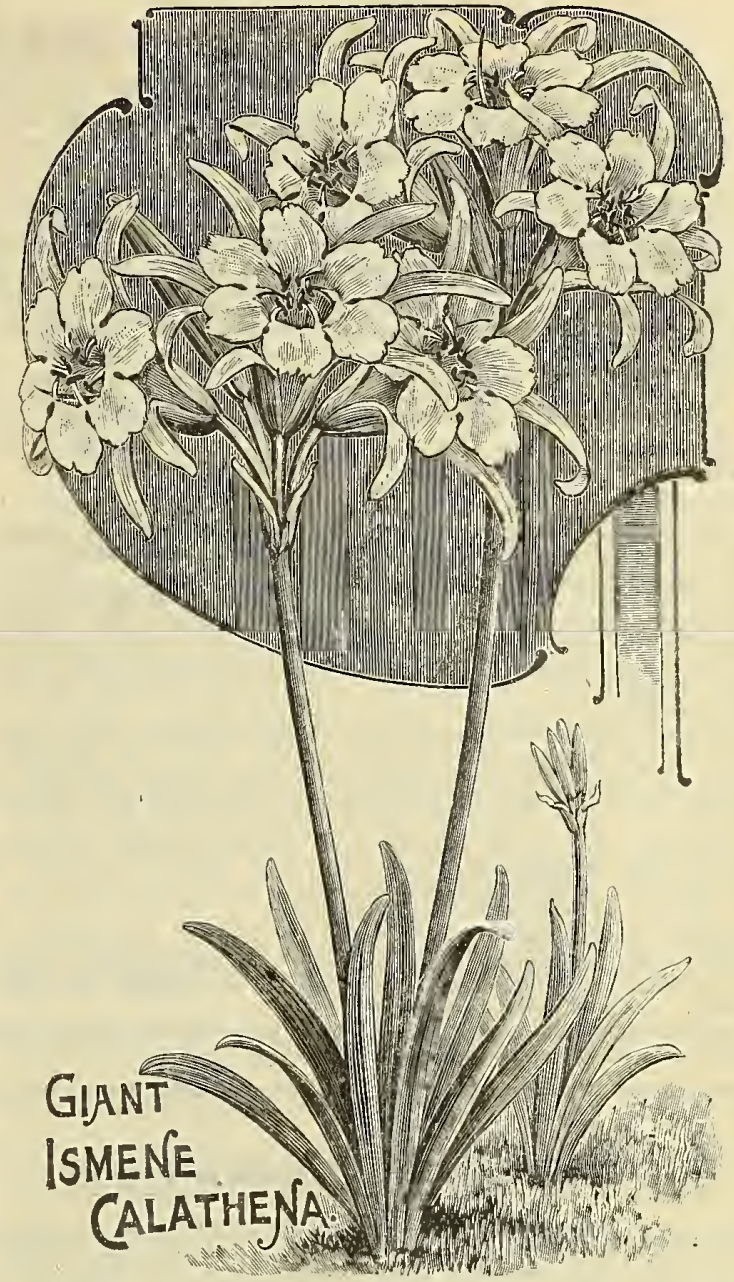

The Great Ismene Caithina. Not"enough can be said in praise of the exquisite beauty and purity of this flower. They are very large Amaryllis like, snow white and of delicious fragrance. In fact they can be called a white Amaryllis. These lovely plants have a peculiar grandeur which one can feel when seeing it in bloom but which is difficult to describe. Bulbs are large and strong and begin to flower a very short time after planting. They send tall flower stems which each bear several of the gorgeous bıs. soms. As a garden bulb treat same as gladioli. Do not fail to plant it. It will more than mak yout susicent Bermuda white trumpet lily. The price brings it vithin the reach of all. Each strong bulb, 20 cents; 3 for 50 cents; 7 for $\$ 1.00$.

\section{DIELYTRA SPECTABILIS}

\section{(BLEEDING HEART)}

An old-fashioned and well known flower, but ever beautif ul in the eyes of the garden friend. The rosy red drooping branches of flowers and the beautif ully fern-like foliage are amongst our best beloved spring blossoms. If planted early in season in pots and grown quite cool these flowers can be had in bloom for Easter. Strong roots with large eyes. Price includes delivery. Each, 25 cts.; doz., \$2.50.

\section{HYACINTHUS CANDICANS}

A species of Hyacinth which blossoms during August and September, growing 3 to 5 feet high, with spikes of pure white flowers 2 feet in length. The bulbs are large, round and solid, and throw up large flower stems which are gigantic spikes of thimble-shaped white blossoms. Planted in the spring they bloom in August, September, and October, strong bulbs producing two, three, and even four flower stems. A bed of a dozen or more bulbs produces a grand effect. A few planted in the centre of a bed of Verbenas, Petunias or other flowers make a beautiful display. They contrast elegantly with Gladiolus. Planted anywhere, singly or in clumps. they are magnificent. For a cemetery nothing can be more beautiful or appropriate and nothing thrives better in any situation. Strong bulbs, sure to bloom. Each 10 cts.; 3 for 25 cts.; 12 for 75 cts. 


\section{IRIS SECTION}

THE FLOWER OF THE GODS

Thousands of years ago this flower has been praised in poetry and song, its beauties extolled and to this our modern days it is recognized as one of the loveliest gems in the garden. It has been called the "Poor Man's Orchid" on account of its glowing and varied colorings which rival the Orchids in fascinating tints. Moreover to grow Iris is possible to every one. Their low cost, easy cultivation, and a variety of species which some of them adapting themselves to wet localities others to dry and sunny places afford a great choice. The Iris worshippers are many and once interested in this particularly beautiful flower, the enthusiast never loses his zeal and pleasure in trying new sorts or hybridizing, growing from seed to obtain new color combinations, new sorts of blossoms. The first to bloom in spring are the following:

Iris Pumila. A lovely and dainty species especially fine grown in clumps or along the border. They at tain only a height of 5 to 8 inches, the varicolored blossoms almost smothering the bright green foliage.

Pumila Coerulea. Clear blue flowers.

Pumila alba, Pure white flowers.

Pumila Formosa. Dark violet. May to June.

Pumila Florida. Lemon yellow with dark golden shadings. A brilliant effect grown with the white and blue. Each 20 cts.; doz., $\$ 2.00$.

Iris Pseudoacorus (Yellow Flag). Very strong growing sort, 2 to 3 feet high with clusters of golden yellow flowers. While it will grow well in any ordinary garden soil it likes a good deal of moisture and will grow especially fine along brooks or water courses where it soon forms large clumps. It is not easily crowded out by grass or other flags. Very showy and effective. May to June. Each, strong rhyzomes, 20 cts.; doz., $\$ 2.00$.

Iris Cristata (Crested or bearded Iris). Height 6 inches. Very handsome aureblue flowers with thick green foliage. One of the best dwarf sorts. Entirely hardy, it soon forms good sized clumps, and can be divided the third season. Give it plenty of room to spread. Flowers in May.

Iris Sibirica. One of the grandest Iris. Perfectly hardy, it flowers May to June. Height 2 to 3 feet.

Iris Sibirica. Blue. Light blue flowers.

Sñow Queen. A magnificent pure white sort.

Orientalis. A deep violet blue.

Iris Ochrocleuca Gigantea. Height 3 feet. Flowers in May. Large pale sulphur yellow flowers. Fine foliage. Very distinct and ornamental. Each 20 cts.; doz., $\$ 2.00$.

Iris versicolor. Loves moist places. Will grow well in garden soil. Height 2 feet. Flowers bright blue. Hardy.

Each Iris on this list where not specially noted, $15 \mathrm{cts}$; doz., $\$ 1.75$.

\section{IRIS GERMANICA-GERMAN IRIS}

These are all deliciously fragrant, more or less mottled in the standards and striped and veined in the falls. In beauty they rival the finest orchids, in colors they range from clear white through yellow, rose, blue, purple, m colors they range

They are one of the most popular forms of the divine flower, Iris, They are one of the most popular forms of the divine flower, Iris,
within the range of every purse, and like Topsy "They just grow" anywithin the range of every purse, and like Topsy "They just grow" any-
where and everywhere. They only ask for a sunny spot well drained, as they do not like to have their little feet in water. The soil needs only to be fairiy rich. Plant shallow, barely covering the rhyzomes with the soil. Too deep planting is injurious to all Iris.

\section{LIST OF BEST SORTS OF GERMAN IRIS}

Admiral Togo. White, faintly tinted lavender, falls and standards lightly bordered purple. Height 2 feet and more.

Atropurpurea Grandiflora. Large dark purple uprights, falls deep striped white at base.

Brooklyn. Standards lavender yellow at base, falls pale blue, base veined brown on white ground, edged yellow, splashed with dark blue, very beautiful.

Candiamus. Light lavender standards, falls reddish purple. Very distinct.

Canary Bird. Canary yellow standards, falls crimson purple. Very

Cordelia. Rosy lilac standards, falls dark velvety crimson, edged rose. A gem.

Darius. Lemon yellow standards with falls of a lighter shade.

Don Carlos. Standards yellow, falls rich crimson penciled on lower half with yellow, centre suffused bright blue. Height 15 inches.

Flavescens. One of the very best, showiest and most conspicuous. When planted in a group the effect is striking. The color is soft sulphur yellow. Plant together with pure white and dark purple and note the artistic color effect. Very fragrant.

Florentina (Orris Root). From these roots is gained the basis of all perfume powders, the orris powder. This is an excellent variety perfume powders, the orris powder. This is

F. Alba. White, faintly tinged lavender. Large flowers.

F. Blue. Tall and vigorous. Clear dark blue.

Honorable. Intense yellow standards, falls a clear beautiful bronze.

L'Africaine. Rosy purple standards, falls darker rose, veined white at base. A beauty. Height 15 inches.
Lizzie. Pure yellow standards, falls dark bronzy crimson.

Madame Chereau. A very fine sort. White standards and falls elegantly frilled aureblue margins. Height 2 feet and more.

Mrs. H. Darwin. One of the finest silvery white sorts.

Neglecta. One of the tallest and earliest of German Iris. Immense clear blue flowers. Striking and handsome.

Mrs. Neubronner. A magnificent deép golden yellow sort.

Parkmanni. Pure lemon yellow standards, falls white, veined blue.

Pearl. One of the very best clear lavender sorts.

Queen of the Gypsies. A very striking and handsome sort. Standards a dusky light bronze, falls velvety purplish red.

Queen Victoria. Bright yellow standards, sometimes tinted brown. Falls crimson striped yellow with yellow edge.

Rebecca. Golden yellow standards, falls yellow striped and splashed with golden brown. Very showy.

Souvenir. Brilliant yellow standards, falls a network of yellow, buff. and purple.

Viola. A very fine clear violet purple.

Each, 15 cts.; doz., $\$ 1.75$; per $100, \$ 10.00$.

\section{PALLIDA SECTION OF GERMAN IRIS}

These are specially strong and tall growing and wherever grown form a beautiful bit of landscape.

Albert.Victor. Soft blue standards, falls a clear beautiful lavender. Celeste. A transparent pale blue. A most enchanting species.

Mandraliscoe. A deep rich lavender violet. Very early and one of the handsomest.

Pallida Dalmatica. The very finest of the species. Of strong vigorous habit the plants attain in good soil a height of 4 feet, with immense deliciously fragrant flowers. Standards are clear lavender, falls lavender shaded a deeper tint. Exquisite in every way. In single specimens or groups.

Queen of May. The only German Iris which is nearly rosy pink. Standards and falls are a soft rose lilac. A very charming tint.

All German Iris bloom from end of May through June.

Any one of this list 20 cts. ; doz., $\$ 2.00$.

Mixed German Iris. Each, 15 cts.; doz., \$1.50; 100, $\$ 10.00$ We furnish strong fine rhyzomes which will flower first season. Six at dozen, 25 at 100 rates.

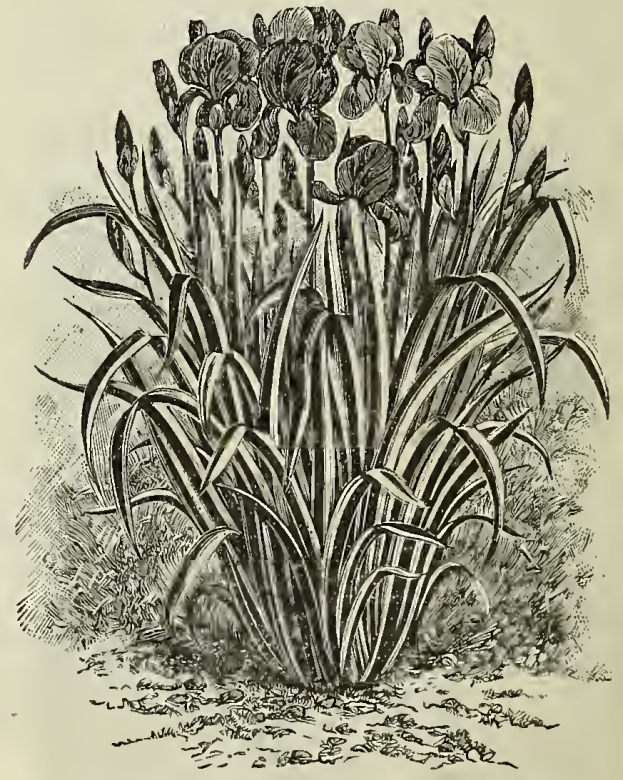

Iris Pallida Dalmatica foliis variegatis

Pallida Dalmatica. Beautifully cream, green and yellow variegated foliage. Large azure blue flowers, Each, 50 cts.; 3 for $\$ 1.25$; doz., \$4.50. 


\section{IRIS KAEMPFERI}

The firm of H. H. Berger \& Co. was the first to import these magestic flowers into the United States, in 1877 , when Mr. H. H. Berger brought the first clumps to San Francisco, Cal. Since then, by slow degrees, these gorgeous plants have found their way into the gardens of flower lovers gorgeous plants have found their way into the gardens of flower lovers
and, once seen, the desire to grow them is sure to induce the purchase of
them.

Quite a few inferior varieties have been allowed to come up amongst the original stock. We strive to offer the best and newest as every season more or less new hybrids are found amongst the stock and in the Iris fields. Others are raised from seed and the variety of colors is bewildering. Some of the hybrids revert after some time to the original tints and we have therefore, done our utmost to offer only fixed types.

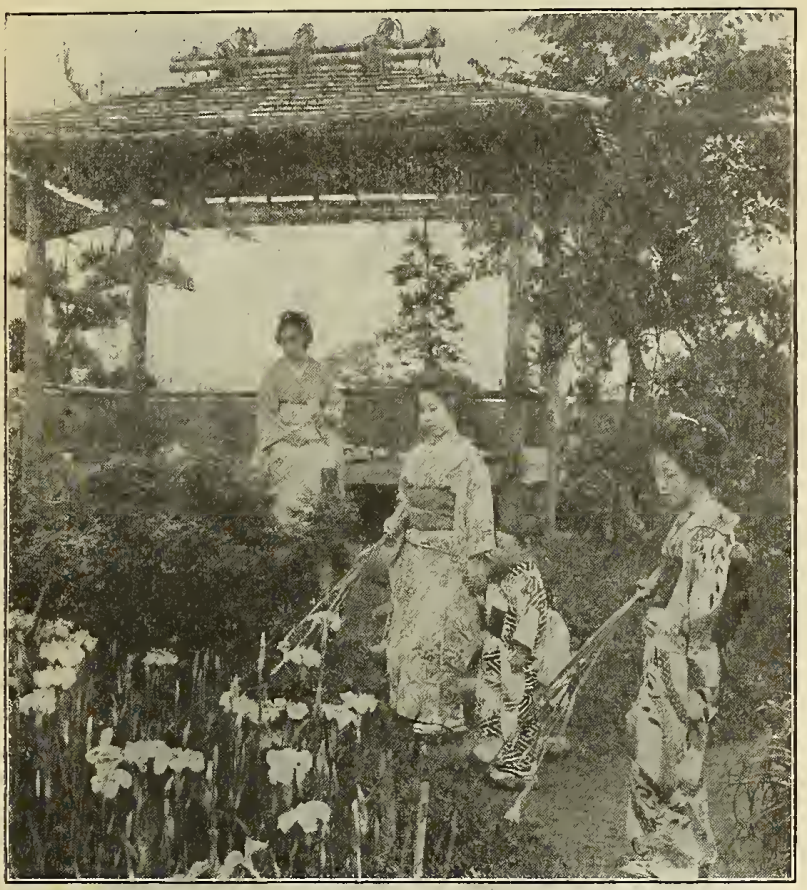

Japan Iris

\section{LIST OF 20 BEST AND CHOICEST IRIS} KAEMPFERI

1. Zama-No-Mori. White, slightly shaded with foggy blue, yellow
blotches radiating into delicate feathers. Standards large, tipped light blotches radiating into delicate
blue. Three enormous petals.

2. Yeddo-Niman. Royal blue, very large petals, standards purple, petaloid stigmas dark violet; 3 petals.

3. Wase-Banri. White, shaded with purple, yellow blotches radiating into purple veins, petaloid stigmas vinous purple; early bloomer; 3 petals.

4. Shokko-Nishiki. Lilac on white ground, flaked and speckled, yellow blotches radiating into purple veins, inner small petals purple; 3 petals.

5. Tora Odori. Gray, overlaid with lavender blue, yellow blotches, petaloid stigmas violet and white; 6 petals.

\section{KINDLY NOTE}

Anyone being interested in Iris Kæmpferi and wishing to see pictures of the twenty sorts we offer, painted in natural colors, true to nature, oblige by remitting us $\$ 5.00$ as a deposit for the return of pictures in good condition. In case of an order being given no charge is made whatever, but if no order is given we given no charge is made whatever, but if no order is given we return the amount, $\$ 5.00$, received, less charges for sending the
pictures. Time given for inspection is ten days. As these sets of pictures are always in great demand, we cannot allow a longe period of time. Return must be made by registered mail or express prepaid. Each picture is painted singly on rice paper, giving every line and contour.

6. Kolki-no-iro. Red purple, suffused with intense blue, orange blotches petaloid stigmas white, tipped purple; 6 petals. Superb.

7. Sano-Watashi. Pure satiny white, yellow blotches, petaloid stigmas creamy white; enormous flower; 6 petals.

8. Choseiden. Ruby crimson, white halo surrounds yellow blotches radiating into broad line, petaloid stigmas light violet; 6 petals.

9. Aoigata. Light purple violet, dark purple halo surrounds the primrose blotches radiating into purple lines, petaloid stigmas dark purple; 3 petals.

10. Nishiki-no-shitone. Claret purple, speckled with lilac, the yellow blotches surrounded with blue halo radiating into lilac lines, standards vinous purple, petaloid stigmas violet; 3 petals.

11. Bandai-no-nami. Pure white with large radiating yellow blotches, standards cream white; 6 petals. A superb white.

12. Kasugano. Smiling God. Delicate red lilac with lilac halo surrounding the yellow blotches radiating into feathers and pencillings, petaloid stigmas violet stained gray; 9 petaled, a marvelously beautiful petalo

13. Oku Banri. Gray feathered and pencilled rich violet, yellow blotches; standards dark purple, stigmas dark violet bordered gray; 3 petals.

14. Hatsushimo. Flower in the wine cup. Pure white, yellow blotches, standards pure white, petaloid stigmas cream; 3 petals. Earliest white.

15. Gosetsu-no-mai. Purple overlaid with cœrulean blue, yellow blotches radiating into white veins, stigmas white bordered blue; 6 petals. A gem.

16. Kuma-funjin. Furple overlaid with navy blue, 2 standard petaloid stigmas purple and blue, very large yellow blotches; 6 petals.

17. Datedogu. Rich claret red, with orange blotches, surrounded with a blue halo radiating out into elegant lines, standards light claret and white, petaloid stigmas white tipped and bordered pale red. Very large flower, magnificent sort.

18. Sofu-no-koi. White splashed speckled and mottled sky blue, primose blotches radiating into the petals, petaloid stigmas creamy white tipped and margined violet; 6 petals.

19. Kuo-kumo. Deepest royal purple overlaid with dark blue, petaloid stigmas dark blue bordered gray; 6 petals. Beautiful contrast if planted with light sorts.

20. Izumi-Gawa. Gray, yellow blotches radiate dark blue veins, petaloid stigmas dark blue bordered gray; 6 petals.

The twenty sorts listed will be found the best of all Iris, selected with great care out of a known set of near one hundred varieties.

Price, each, strong clump, 20 cts.; doz., $\$ 2.25$. The set of 20 , $\$ 3.50$. Delivery not included.

If delivered, each $25 \mathrm{cts}$; doz. $\$ 2.50$. The set of $20, \$ 4.00$.

Immense clumps with 5 to 6 strong eyes, sure to flower first season Each 35 cts.; doz., $\$ 3.50$. Set of $20, \$ 6.50$, delivered.

\section{LILIES}

\section{"PLANT WHITE AND GOLDEN LILIES FOR BEAUTY. "YELLOW, SCARLET, AND ORANGE FOR SHOW"}

From the land of the rising sun come to us the greatest treasures in lilies. Amongst them all the "auratum" holds its own. Children too young to have studied Geography, people so old that they have about forgotten its importance, recognize to-day this lily as one of their dearest possessions, awaiting its return to bloom each season with impatience. This Lily makes a direct appeal to the affection. It stands so erect and so tall, while its fragrance catches the senses and the astounding size of its tall, bloom, sometime a the golden band through each petal give to it so alluring a personality that an extract of a letter received amongst many others.
One letter out of many hundreds received from pleased customers.

Peoria, Ill. October 24, 1914.

The Auratum received from you was the largest and finest ever grown in our City. One stalk had blooming at one time, seven blooms each measuring from 10 to 11 inches across. It was a wonder. B. COWELL. 


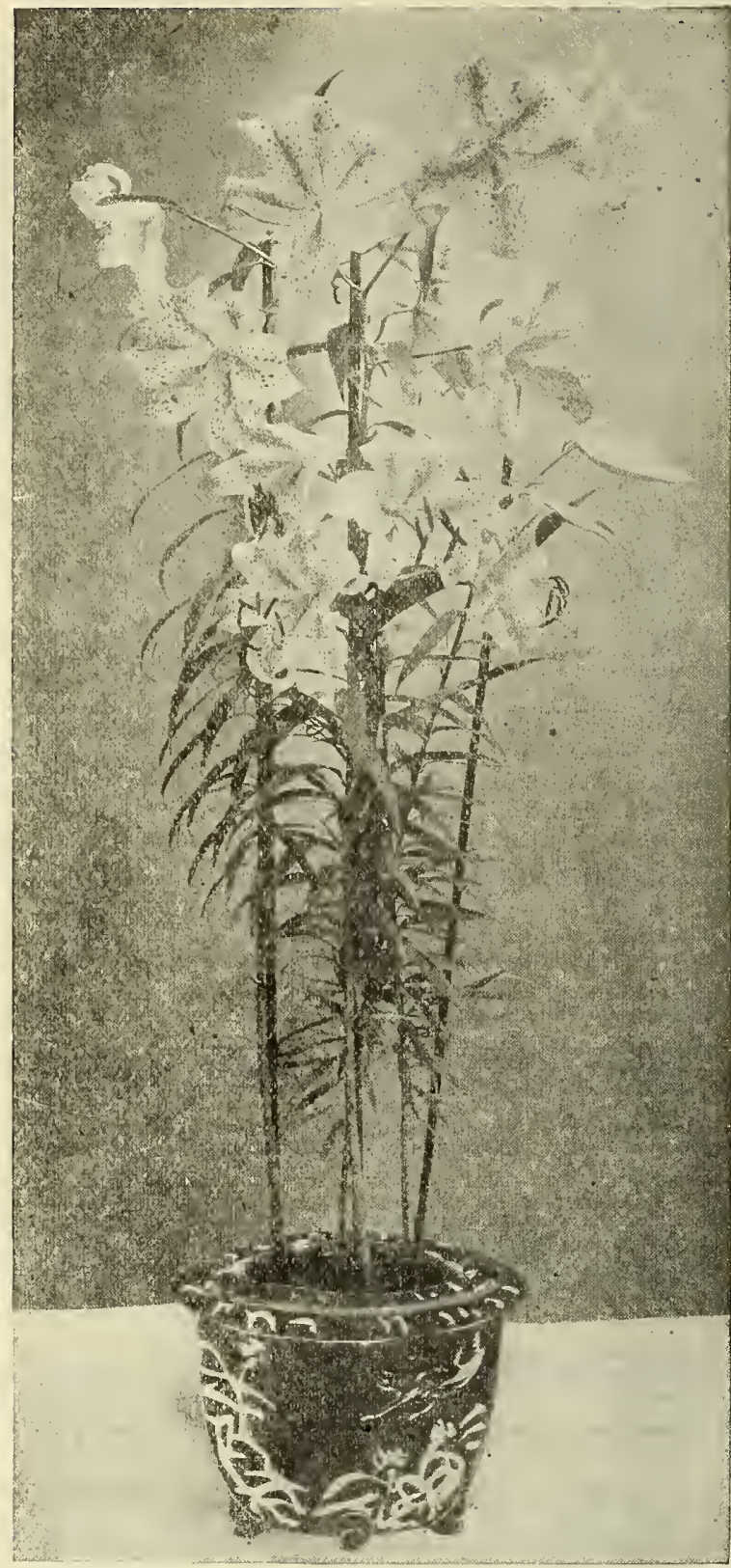

\section{AURATUM TYPES}

All bulbs will flower the first year. Small bulbs under the size of a good sized apple will not flower until a second or third season.

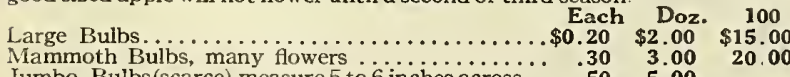

Jumbo Bulbs (scarce) measure 5 to 6 inches across .. $\quad .50 \quad 5.00$

\section{RARE SORTS OF AURATUM TYPES}

Platyphyllum or Macranthum, leaves are long and broad. Heigh 6 to 7 feet. Flowers clear white with golden yellow band through each petal. A royal bloom. Very hardy.

Large-Bulbs

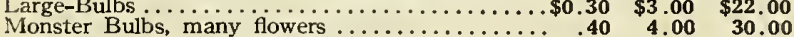

A. Wittei. A beautiful flower. Petals pure white with a wide yellow stripe through each petal, and white raised dots $\ldots \ldots \ldots \ldots \ldots \ldots \ldots \ldots \ldots \ldots \ldots$

L. Virginale Alba. Enormous flower with golden band through centre, and raised creamy spots. Resembles A. Wittei, Dut has a much larger

flower .........................5. 500
A. Pictum. The petals of this sort are very large. Each Doz. overlapping each other. The ground is white, dotted richly with bright crimson spots; a band of red with golden halo through centre of each petal. One of the very finest auratum sorts. petal. One of the very finest auratum sorts. $\$ 0.50$ \$5.00

Auratum Rubrum Vittatum. This is the gem of all Auratum sorts. Imagine an immense flower with heavy large petals of clear white, through the centre of which passes a blood red band and with the petals spotted, flushed, and dotted with brilliant crimson or blood-red. This lily is difficult to describe. It is so superb. Good flowering bulbs $\ldots \ldots \ldots \ldots \ldots \ldots \ldots \ldots$

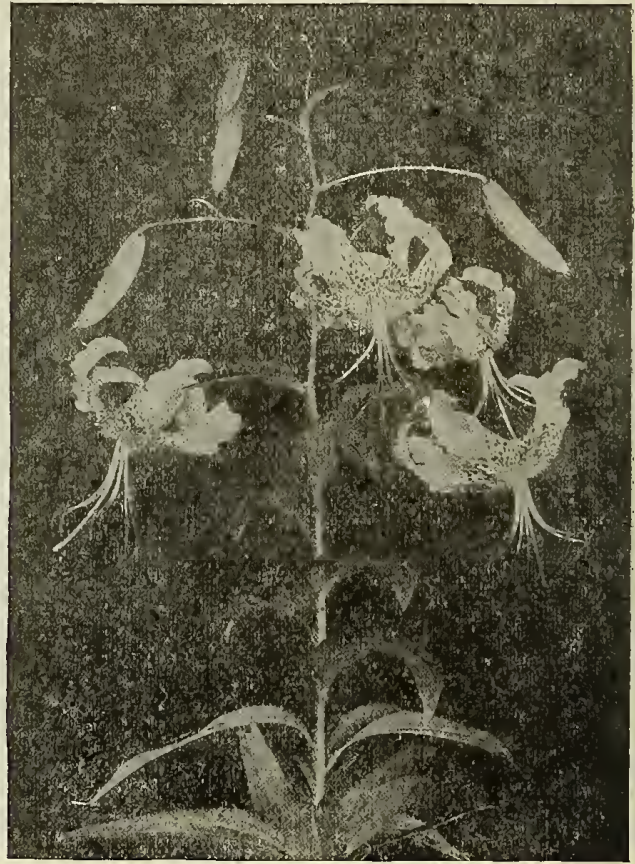

\section{SPECIOSUM TYPES FROM JAPAN}

All bulbs belonging to type have in common a very sturdy and vigorous growth, tall stiff stems from 3 to 5 feet high, very handsome deep green foliage and reflexed petals. They grow with greatest ease, hardly ever fail to bloom profusely and multiply from bulblets which are borne in the axils of the leaves. They can remain wherever planted for a number of years.

Speciosum Album. This is the pure white form Each Doz. 100 of Speciosums. The center of petals has a soft

fringe which enhances its beauty. It is without

doubt the finest pure white garden lily. Fin

flowering bulbs ...................... \$0.20 \$2.00 $\$ 15.00$

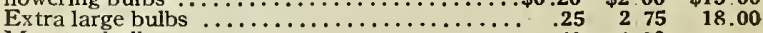
Monster bulbs $\begin{array}{llll}.25 & 2 & 75 & 18.00\end{array}$

Speciosum Rubrum. The type with reflexed petals. On a white ground are a number of petals. On a white ground are a number of

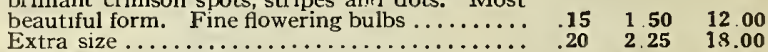

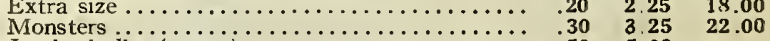

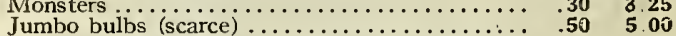

Speciosum Magnificum. "Resembles Rubrum but the spots and lines are much deeper and the whole flower is flushed a deep carmine red ..... Extra size $\ldots \ldots \ldots \ldots \ldots \ldots \ldots \ldots \ldots \ldots \ldots \ldots \ldots, 20 \quad 2.25$

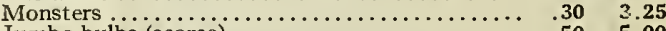
Jumbo bulbs (scarce) ................. .50 $\mathbf{5 . 0 0}$

\section{LILIUM HENRYI, THE YELLOW} SPECIOSUM

A most beautiful variety found within the last ten years in northern China. Nothing compares with this lily in hardiness, profusion of bloom, and glorious beauty. In masses it is simply stunning. The tall stems rise 4 to 6 feet bearing an incredible mass of flowers, remaining in bloom for a long time. The color is a rich apricot yellow, lightly spotted with brown. It succeeds really anywhere, it is so hardy.

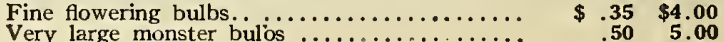

Each Doz. 


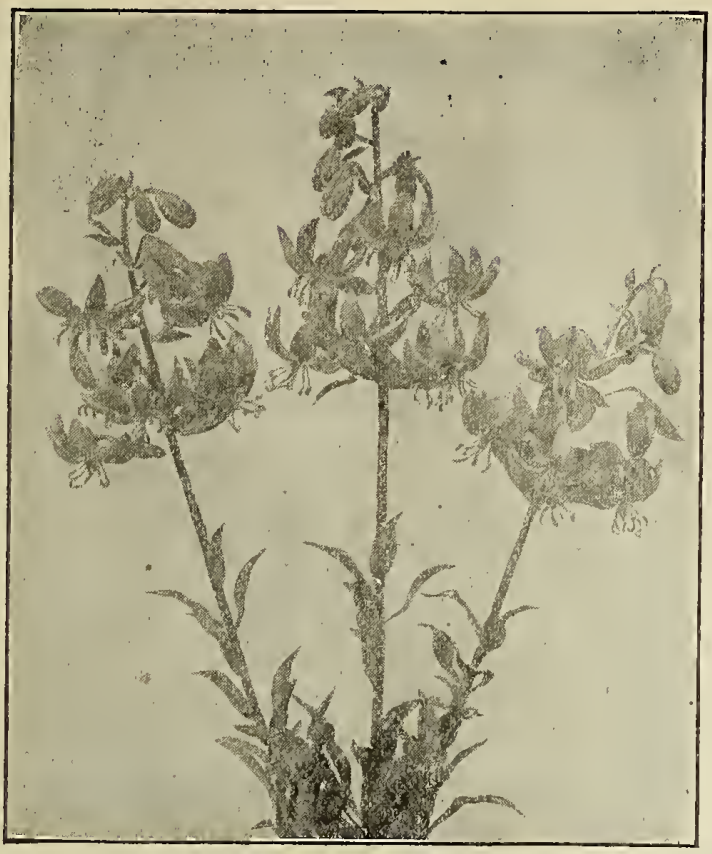

Lil. Hansoni

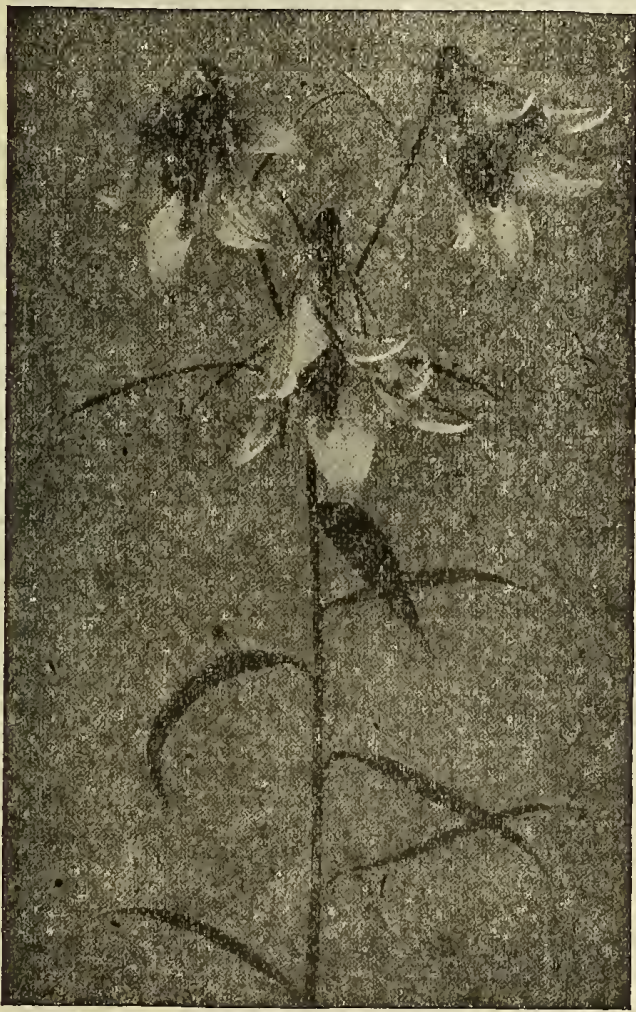

Lil. Krameri and Rubellum Type

\section{LIL. KRAMERI AND RUBELLUM}

Gems of Lilies which can only be imported safely in spring

Krameri. The type. Short trumpet, rosy hued, Each Doz. 100 beautiful. Strong bulbs (which however never

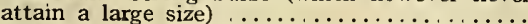

Rubellum. So to speak, a glorified Krameri. Blush to deep rose. a magnificently enchanting lilv $\begin{array}{lll}30 & 3.00 & 18.00\end{array}$ $30 \quad 3.00 \quad 18.00$
VARIOUS HARDY GARDEN LILIES FROM JAPAN AND EUROPE

L. Batemannii, 3 to 4 feet high Each Doz. 100 and robust lily succeeding anywere hardy a glowing apricot; upright chalix, dark anthers. Very showy $\ldots \ldots \ldots \ldots \ldots \ldots \ldots \ldots \ldots \ldots \ldots \ldots \ldots$

L. Brownii, 3 to 4 feet high. One of the fines lilies known. Immense trumpet-shaped flowers: inside pure white with chocolate colored anthers, outside of petals flushed reddish or purplish

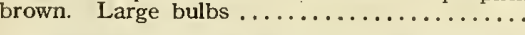

L. Colchicum (Sovitzianum), 3 to 4 feet high. A magnificent lily. Color a citron yellow (so rare in llies), spotted with dark dots, almost black brown anthers. One of the earliest varieties to

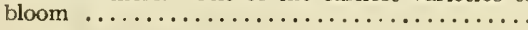
L. Croceum (Bulbiterum) 4 to 5 feet high. Broad,
funnel shaped flowers. A beautiful golden color, slightly flushed scarlet. Blooms in July ...

L. Excelsum (Isabellinum or Testaceum). 4 to 6 feet high. A most beautiful and stately lily. Produces in June to July numerous delicate buff colored lilies. Wherever seen it attracts admira-

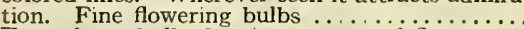
Extra large bulbs bearing masses of flowers....

L. Elegans. All Elegans sorts have upright standing flowers with wide open petals. Grow anywhere on well drained scil and in a sunny spot. Multiply rapidly and are one of the most satisfactory cheap lilies to grow. Splendidly adapted factory cheap lilies to grow. Splendidly adapted for mass.

L. Elegans Red Flame, $2 \frac{1}{2}$ to 3 feet high. Color

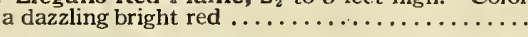

L. Elegans Atropurpureum. One of the finest of the type. Co or atrich velvety crimson shaded

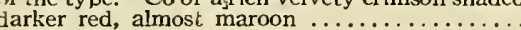

L. E.legans Incomparabile. Red with gorgeous golden shadings. Very bright rolor ..........

L. Elegans citrinum. $\Lambda$ delicate citron yellow. Most attractive $\ldots \ldots \ldots \ldots \ldots \ldots \ldots \ldots$

L. Hansoni. A queen amongst lilies; 4 to 5 feet high. Flowers very early end of May to June. Waxy petals résembling a beautiful orchid. Color lemon yellow with rich purplish or orange spots. One of the eas est to cultivate and very siurdy and

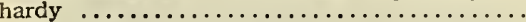

L. Marhan, 6 to 7 feet high. A lovely hybrid between Martagon album and Yansoni. Habit and shape of I.. Martagon and the thick waxy petals of Hansoni. Unique color, a clear buff shaded orange with brownish red spots and streaks. Vrange with brownish red spots and streaks.

L. Martagon. 2 to 3 feet high. Purplish red, dark spots. Prolific bloomer; very odd and

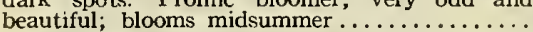

L. Martagon White, 3 to 4 feet high. A rare species of this type. Unique and exquisite. Pure white form of Martagon. As many as 20 flowers of waxy whiteness to the stem. A gem amongst of waxy whiteness to the stem. A gem amongst

L. Myriophyllum. A recent introduction from China; 2 to 3 feet high. The flowers are short trumpets, white suffused pink, and a canary colored shading in centre extending part way up colored shading in centre extending part way up
the trumpet. Blooms early. Very fragrant: the trumpet. Blooms early. Very fragrant:

L. Sargentiae. Also a recent introduction from China; as yet rare; 4 to 5 feet high. Trumpet. shaped, greenish white, shaded purple on outside; white with citron centre on inside. Blooms in August.............................. 100.00

L. Tigrinum, 3 to 5 feet high. The old well-known Tiger lily. Large pyramids of flowers, orange

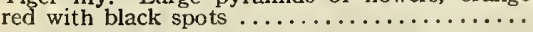
L. Tigrinum flore pleno. The double flowering
Tiger Lily, 4 to 6 feet high. Bears a large number of double orange red flowers with dark spots ....

L. Tenuifolium. The Coral Lily of Siberia. A charming lily. 20 to 24 inches high. Has beautiful finely cut foliage and masses of nodding bright coral red flowers with reflexed petals. A group of them planted in the shrubbery or on the lawn forms a veritable mass of living flame.

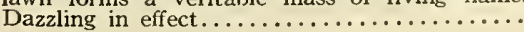
Extra strong bulbs 


\section{LILIES NATIVE OF THIS CONTINENT}

The United States of America boasts of many and varied magnificent lilies, a list of which is herewith given. All are ready in October. They are all hardy, of particularly strong growth, succeeding with little care; need no coddling.

L. Canadense. The dainty native Canadian lily. Bright yellow, copiously spotted red. Blooms in Bright yellow, The dainty native Canadooms in

L. Canadense Rubrum. Same type but a bright crimson with dark spots.......................

L. Canadense Flavum. The pure yellow type.... .

L. Wallacei. Dwarf species. Very showy. Pale red flowers. One of the best for ordinary garden culture...............................

L. Grayi. Dark red-brown petals, beautifully spotted. An exquisite species and very rare......

I. Pardalinum (Leopard Lily). A magnificent garden lily, 3 to 6 feet. Grows best in slightly gravelly soil, partial shade and a fair amount of moisture. Flowers are borne in abundance on stout leafy stems. Flowers, rich orange with red centre and crimson tips. They increase rapidly and give greatest satisfaction for hardiness and showy bloom ...........................

L. Humboldtii, 5 to 7 feet high. A magnificent lily with a wealth of large orange colored flowers with bright purple spots, reflexed petals borne on very stout stems and lasting a long time. A group of these superb lilies is a grand sight. They grow with greatest ease and flower with marvelous prowith greatest ease and flower with marvelous profusion; 30 to 40 thewers having been caund on one stem. Are as hardy as rocks, and can remain
undisturbed for years. In every way one of the most desirable garden lilies. Extra strong bulbs.

L. Philadelphicum, 2 to 3 feet high. A very dainty, pretty species. Orange red, freely spotted deep purple. Very floriferous.................

ach Doz. 100

$0.12 \$ 1.25 \$ 10.00$

$\begin{array}{lll}.12 & 1.25 & 10.00\end{array}$

$\begin{array}{lll}.12 & 1.25 & 10.00\end{array}$

L. Superbum (Turk's Cap Lily). Unsurpassed for effective planting, 5 to 6 feet high. Erect stout stem with clusters of orange red flowers, heavily spotted a light brown. A truly regal lily when in bloom and a sheet of flame when seen in the shrubbery or border. Extra strong bulbs.....

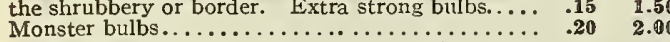

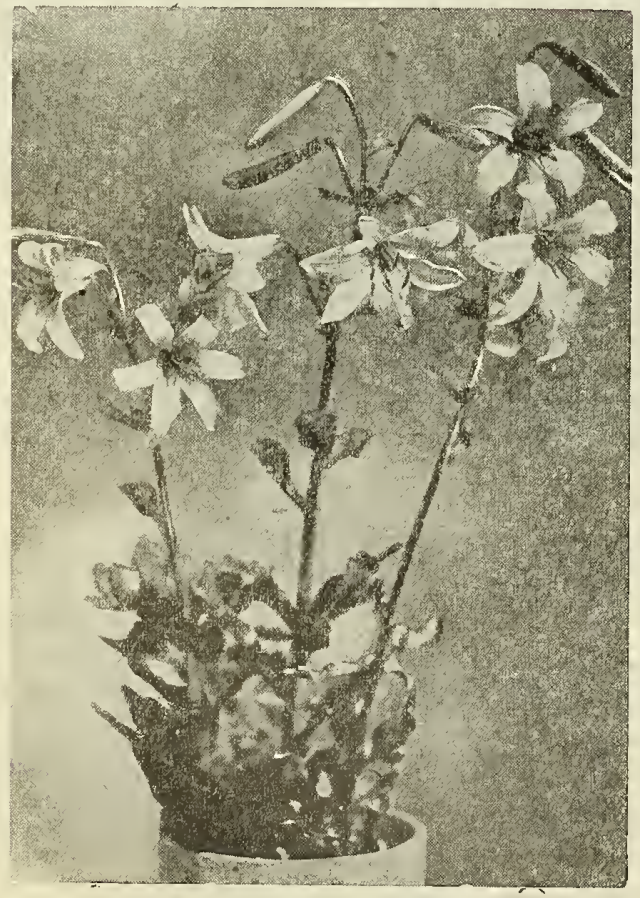

Lilium Washingtonianum

Evis. The Queen Lily of the Paciffe Coast
L. Washingtonianum. A gorgeous lily, 4 to 5 feet high. Above the stout stems appear the widely expanded trumpets. Opening pure white they change to blush rosy red and, before fading, into a deep wine color. The perfume is simply entrancing. When blooming in its native woods in the high Sierras one of these lilies blooming will lead you for a long distance by its fragrance. It is certainly one of the noblest, and finest lilies is certainly one of the noblest, and finest lilies partly shaded situation, although also doing well partly shaded situation, although also doing well in sunshine it blooms best where shrubbery or trees
afford a partial shade. Large bulbs............. Mammoth bulbs...................... $\quad .50 \quad 5.00$

\section{THE LILY BED}

Lilies should be planted where they are protected from cold winds and where the soil is not dried out by the direct heat of the sun. On large grounds the ideal location is a glade in the woods. The partial shade of deciduous trees, the shelter of rhododendrons or bamboos, or similar shrubs, or of tall-growing perennial plants, may give conditions quite suited to their culture. A protected nook on the shady side of the house is best on small grounds and ferns are congenial neighbors.

Drainage. This must be perfect. If the ground is heavy and clammy, underdrainage should be given, and the soil made lighter and looser by the addition of humus.

Planting. They should be planted so that the top of the bulb is not less than 4 inches from the surface; about each bulb put a layer of an inch or so of sand which will carry away excessive moisture and prevent fungous attacks.

\section{MONTBRETIAS}

These are amongst our finest and showiest summer flowering treasures. Bearing from I 8 to 30 showy star-shaped flowers varying in every conceivable flame-color through yellow, orange, crimson, and vivid scarlet, their beautiful blossoms create spots of glowing flame and light in the garden. Height 2 to 3 feet. Plant in spring and protect during winter garden. Height 2 to 3 feet. Plant in spring and protect d

with litter of leaves. Blooming time August and September.
The Montbretias are one of the finest of our summer flowering bulbs. They produce many branching spikes covered with a profusion of flowers lasting many weeks in full beauty. They are grand for cutting and decorating.

Crocosmifloræ. Deep clear orange.

Etoile de Feu (Star of Fire). Bright vermilion golden centre. Rayon d'Or (Golden Gleam). Yellow and brown.

Potsii. Bright vermilion.

Any on this list, per doz., 40 ets.; per $100, \$ 2.50$; per $1,000, \$ 10.00$ delivered.

\section{SOME EXTRA FINE NEW MONTBRETIAS}

Giant Flowering Germania, 3 to 4 feet high, with
many branches, free flowering spikes, bearing
masses of very large brilliant scarlet flowers...... $\$ 0.06$

Prometheus. The largest flowering Montbretias known. The stems grow 3 to 4 feet high, with
numerous branches; the flowers are 3 to 4 inches numerous branches; the flowers are 3 to 4 inches across and are borne in greatest profusion, giving color is a rich orange with a brilliant crimson

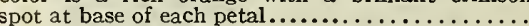
One each of the four Novelty Montbretias, 5 oc.

\section{OXALIS SUMMER FLOWERING}

Very beautiful in groups for edging in hanging baskets, and window boxes. They produce a mass of bright green foliage almost hidden by the brilliant hued blossoms, which are saucer shaped. Height 5 to 8 inches. Plant in ordinary good garden soil in sunny spot. Bloom all through summer.

Dieppi. Pure white, very fine.

Lasandria. Rose pink, very finely cut foliage.

Shamrock. Cloverlike foliage (the true Irish

sort), blossoms rosy pink $\quad \begin{array}{lllll}12 & 100 & 1000\end{array}$

Any of the above listed $\ldots \ldots \ldots \ldots \ldots \ldots \ldots \ldots \ldots \ldots \$ \ldots .15 \quad \$ \ldots 0.75 \quad \$ 5.00$

Mixed sorts.......................... .10 $.60 \quad 4.00$ 


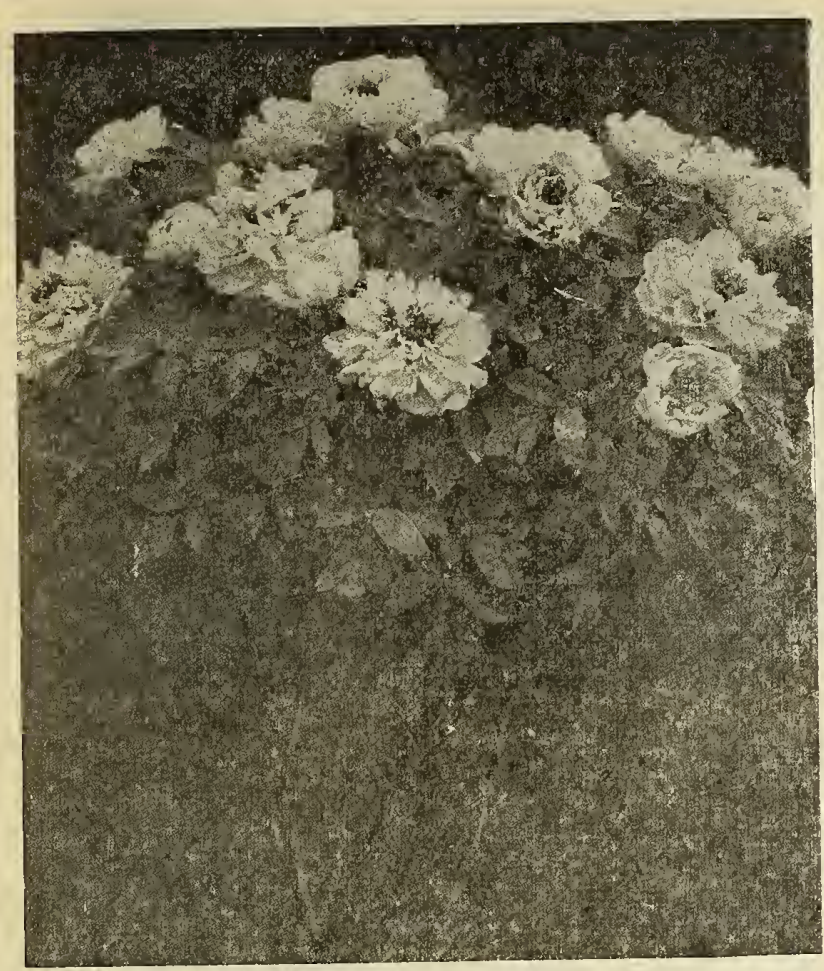

Japan Tree Pæonias

\section{JAPAN TREE PAEONIAS}

This variety of Pronia is so perfectly beautiful and so ornamental that were it better known, everybody would want it in their gardens. It grows, contrary to the Herbaceous sort, which dies down to the ground every season, into a shrub from 6 to 8 feet in height, crowned every season with

In Japan the exhibition of Tree Pronias is a yearly event and festival to which thousands of persons" come from far and near. The specimens are exhibited in pots, and the wealth of bloom is truly marvelous.

These Pæonias are grafted on the stock of Pæonia mutabilis. The varieties we offer are chosen from a bewildering mass of sorts, but we have carefully picked out the greatest variety of color and the finest forms of flowers. The Tree Pzonia must be planted into rich soil, being a greedy feeder, much like the .Chrysanthemums.

\section{LIST OF CHOICEST TREE PAEONIES}

1. Yoyo No-Homare. Fiery rich scarlet petals, with tasseled primrose anthers. Diameter, 10 inches.

2. Yaso-Okina. White, tinted creamy yellow. Diameter, 12 inches.

3. Iro-No-Seki. Delicate blush. Immense flower. Diameter, 13 inches.

4. Muhensai. Rich rosy pink, petals shaded delicate pink, tasseled golden anthers. Diameter, 10 inches.

5. Shi-un-Ryu. Velvety rich violet. Magnificent, when planted as contrast to light sorts. The rarest tint imaginable. Diameter, 12 inches.

6. Mikasayama. Rich salmon rose, with tasseled yellow anthers Diameter, 11 inches.

7. Kokirin. A dazzling scarlet. Very showy. Diameter, 12 inches.

8. Adzumagakami. Splendid glowing carmine. Diameter, 12 inches.

9. Tokiwadzu. Rosy lilac petals of immense size, with tasseled golden anthers. Enormous size of 15 inches.

10. Akashigata. Rosy red petals, fringed and undulated, with yellow tasseled anthers. Diameter, 14 inches. A gem.

11. Seirin. Satiny white. One of the best. Diameter, 12 inches.

12. Shokikagura. Satiny rose blush, rose margin. Very double and compact. Very beautiful. Diameter, 12 inches.

Each of these 12 Tree Pronias, $\$ 1.00$. The dozen, $\$ 10.50$,

\section{THE TYCOON}

Novelty. The most gorgeous grand flower ever produced in Japan with enormous rosy lilac petals, ragged and undulated; 16 to 17 inches in diameter. Each, \$2.00. Rare.

Order early to secure this beauty.

\section{PAEONIAS}

Amongst the many popular herbaceous plants it would be hard to find Amo pronia. The that fits into any position in the garden or grous (May and June) is most effective, while the dark green foliage is at all times attractive. What better frontage for shrubs or, in fact, for any small or large plantation than Pzonias? They are eminently suited for massing in beds by themselves, or used as borders, or as single specimens in the lawn. They are lovely anywhere. Give the place where the Pronias are to be planted a thorough spading, yes, trench the ground, working in a liberal supply of thoroughly decomposed manure, and again top dress in fall as Pæo nias are gross feeders, and will only produce very large and brilliantly colored flowers under Good feeding. Do not expect too much the first season. They are a little slow in their growth, but after a season or two if they are well cared for, you will enjoy an ever increasing abundance of beautiful bloom.

\section{HERBACEOUS FRENCH PAEONIAS}

Couronne d'Or Immense. Very full bell-shaped flowers: color snowy white with yellowish reflex, light carmine edges on a few of the center petals. Grand for cutting. Late blooming; comes in after all other whites are done... Eugene Verdier. Pale Hydrangea pink center, flecked

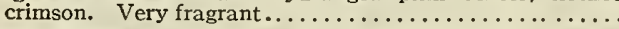

Felix Crousse. The ideal self colored Pæonia. Large, giobular and compact. An even beautiful shade of bright giobular and compact. An even beautiful shade of bright
red. Strong vigorous grower. .................. Festiva Maxima. Enormous, full and double. In color one of the most beautiful white Pæonias...............

Triomphe du Nord. A most unique shade. Even lilac rose. Plant with dark maroon for contrast. Mid-season. Margaret Gerard. Enormous flat shaped flowers, blooming in clusters. Pink changing to creamy white. Sweetly

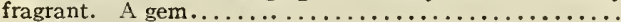

Marie Lemoine. Ivory white. Gigantic flowers........ Monsieur Krelaaage. Deep currant red with amaranth center. Large flat flowers as big as a plate. A grand acquisition............ Queen Victoria. A splendid every day white. Exquisite in the bud state when it is a delicate blush....

Gloire de Douai. Purplish scarlet crimson with black reflex. Late.........................................

Edulis Superba. This is the famous Memorial Day Pæonia. A beautiful bright, clear rose with silvery reflex. Mons. Chas. Leveque. Blending into salmon. An exquis-

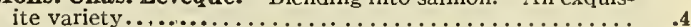

One each of these beautiful Paeonies listed, 12 plants, $\$ 4.60$ Mixed Herbaceous Paeonias, three, 75 cts.; doz., $\$ 2.50$.

\section{SIX CHOICEST SINGLE OR LOTUS FLOWERING SORTS}

\section{JAPANESE HERBACEOUS PAEONIES}

1. Fujiso megino. A magnificent rose tint like a pink lotus flower. Centre filled with golden stamens.

2. Takaradama. Immense semi-double flower, centre and outer petals a satiny white. Very free bloomer

3. Tatsu-Gashira. Large pink flower, striped with pink, and red centre filled with golden stamens.

4. Sumi-no-ichi. A truly magnificent flower. Velvety shade of royal purplish red with a corolla of yellow stamens. A gem.

5. Reikaizan. The softest flesh pink filled with yellow stamens in centre. A great beauty.

6. Kocho-no-mai. One of the showiest and best. An intense carmine red, the centre full of golden yellow stamens. Each 60 ets. One each of the 6 single Japan beauties, \$3.25.

\section{BEST SIX DOUBLE JAPAN HERBACEOUS PAEONIAS}

1. Kasane-jishi. Large globular bloom, centre petals tipped pale salmon, outer petals paler rose. Very striking.

2. Fuji-no-Mine. Large flower well opened, outer petals pure white; centre petals curled creamy white. Fine.

3. F Yamatosangai. Very full, tall flower, softest flesh color, interspersed - by creamy white; narrow petals beutifully arranged in three layers.

4. Yayoura. Very large double flower, white fringed petals, carminestreaks at the tips. Beautiful.

5. Someganoko. Brilliant carmine crimson flower, centre petals salmon, edged with gold. A glorious variety.

6. Benisangai. A most rare and magnificent sort. Full, tall double benisangai. A most rare outer and centre petals interspersed with white narrow petals forming three layers. Must be seen to get an idea white narrow petals forming three
of the showy beauty of this flower.

Each strong clump on this list, 60 ets.; the six (one of each) $\$ 3.25$. 


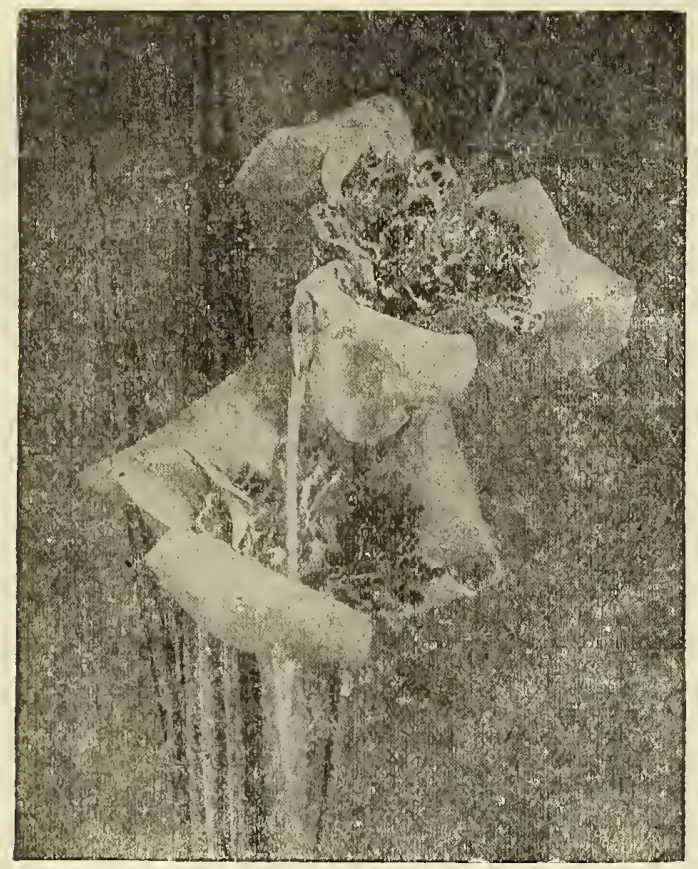

TIGRIDA. SHELLFLOWER

Brilliant colors, mixed

Each Three Doz. $\$ 0.06 \$ \$ 0.15 \$ \$ 0.50$

\section{ACIDANTHERA BICOLOR}

A lovely bulbous plant. Each flower stalk produces from four to eight widely expanded frant widely expanded fragrant flowers, of creamy white color with broad vis are blotches. The flowers are very lasting and being borne on long stems are like Gladioli. $15 \mathrm{cts}$. each; $\$ 1.50$ per doz.

\section{COOPERIA Drummondi (Evening Star)}

This bulb belongs to the Amaryllis family, and can either be grown in pots or open grounds. The beautiful lily-like flowers are borne on stems Io to 15 inches high, and flower profusely. Its flowers spring up as ty magic repeatedly through the season. Color, pure white. Bulbs, large and strong. 5 cts. each; 6 for 25 cts.

\section{MILLA BIFLORA}

F Pure waxy white flowers, star-shaped, borne in clusters of two to three - Pure waxy white fowers, star-shaped, borne in clusters of two to three

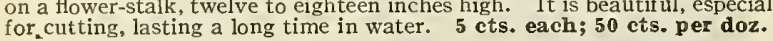

\section{HEMEROCALLIS (Yellow Day Lily)}

The Day Lilies are undoubtedly among the finest plants for ordinary garden culture, as they will grow anywhere in either partial shade or full sun. The flowers are produced in spikes of from six to a dozen blooms, opening in succession, and are very useful when cut for indoor decoration. Flava. The old-fashioned yellow day lily fragrant flowers of deep lemon yellow in June and July. $15 \mathrm{cts}$. each; $\$ 1.50$ per doz.

Gold Dust. Of a bright Indian yellow color, buds and reverse of petal bronzy gold; $2 \frac{1}{2} \mathrm{ft}$. high; flowers in May and June. 20 cts.' each; $\$ 2.00$ doz.

\section{FUNKIA (Plaintain or Day Lily)}

Japanese perennials which delight in moist, shady situations. Most attractive. Used as edging plants for borders or as groups in the shrubbery. or as masses by waterside.

Variegata. This sort has crinkled bright green foliage with white variegations. Flowers purplish lilac. Very fine.

Subcordata grandiflora (Corfu Lily; White Day Lily)." Handsome spikes of large, waxy-white blossoms, deliciously fragrant.» Each_20 cts.; $\$ 2.00$ per doz.

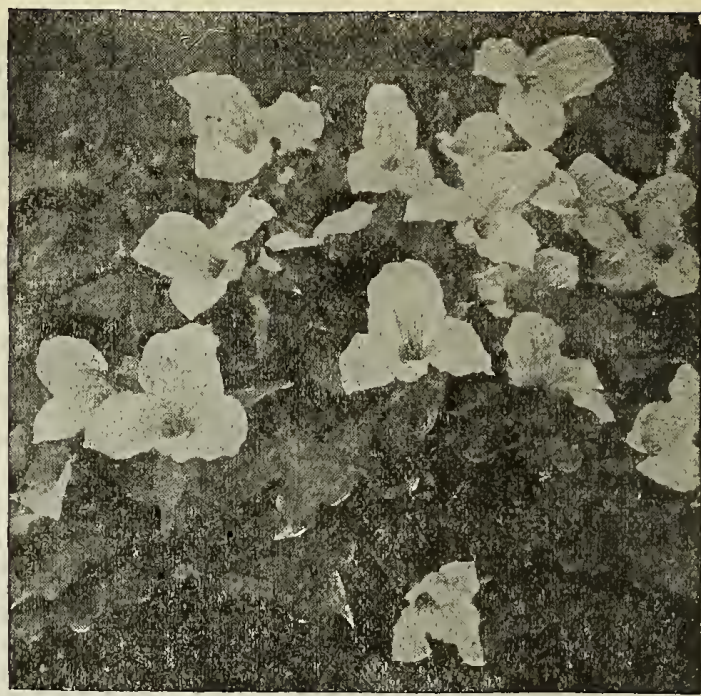

Trillium (Wood Lily-Wake Robin)

\section{TRILLIUM (WAKE ROBIN) WOODLILY}

Spring's harbinger in wood and glen. Earliest flowering plants. Large handsome green foliage, which continues for a long time. Plant early in spring. Height 1 foot to 15 inches. Each Doz. 100 T. Erectum. Large purple flowers .......... \$0.12 $\$ 1.25 \quad \$ 8.00$ T. Snow Queen. Beautiful white flowers...... $15 \quad \mathbf{1 . 5 0} 10.00$ All Trilliums flower early in May. Are especially adapted to woodlands, wild gardens, or amongst shrubbery.

\section{TRITOMAS (RED HOT POKER) FLAME- FLOWER - TORCH LILY}

Pfitzeri. Everblooming Tritoma. The best and freest ffowering of all. Orange-scarlet, shading to salmon rose at the edge. Other varieties all. Orange-scarlet, shading to salmon rose at the edge. Other varieties is by far the showiest of all Tritomas. Plants should be well protected in winter. Height 2 to 3 feet. Blooms August through September, in winter. Height 2 to 3 feet. Bloom

T. Uvaria. Grandiflora. Flowers rich ocher red, and yellow fading salmon. Each listed, 20 cts.; doz., \$2.25.

\section{TUBEROSE - THE PEARL}

The one flower the rich man must have and the noor cannot do without. We all love its massive spikes, thick, waxen blooms of rich, creamy whiteness, and its deep, delicious fragrance. Plant about the middle of May. Give them rich soil, in full sun, and keep free from weeds, and they will bloom freely.

Excelsior Pearl. First introduced years ago. It is the finest bloomer of all Tuberoses; habit dwarf, flower stalks short, spikes and blossoms enormous in size and very double and fragrant. The finest for pots as well as for the garden. Large select bulbs, each 6 cts.; 3 for 15 cts.; doz., 50 cts.

Tall Double. The old popular variety. Splendid for the open ground. Each 5 cts.; 5 for 20 cts.; doz., 40 cts.

\section{WATSONIA - BUGLE LILY}

This is one of the finest bulbs from the Cape. The flowers appear on gladiolus-like spikes, and vary in all colorings. Can be planted outdoors where they bloom June to July. Treat same as Gladiolus. Finest colors mired, each 10 cts.; doz., $\$ 1.00 ; 100, \$ 7.50$

New White Watsonia. (Watsonia Ardensei Alba). The bulbs, something like those of Gladiolus, send up branching stems, 3 to 4 feet high. each stem bearing a dozen or more flowers $2 \frac{1}{2}$ to 3 inches long by 2 inches across. Its pure snow-white color and great substance render it exceptionally beautiful as a cut flower. Plant in spring in the garden, like Gladioli. A strong plant will bear as many as 250 to 300 flowers in a summer. Strong bulbs, each 25 cts.; doz., \$2.50.

\section{ZEPHYRANTES}

The Zephyr Flowers, or Fairy Lilies, are gems of rare beauty, and when planted either in pots or the open ground they produce very beautiful lily-like flowers nearly all summer. When once grown ihey are always grown, for they are one of the prettiest and easiest grown flowers it is possible to have. For pot culture plant three or four in 5- or 6-inch pot and they will bloom beautifully. For the garden, plant in spring and lift in the fall, like Gladiolus.

Rosea. Beautiful clear rose; large and handsome. Each 10 cts.; 3 for 20 cts.

Atamasco. Large pure white. Each 5 cts.; 5 for 20 cts. The three sorts, one of each 25 cts.; doz., $\$ 2.50$. 


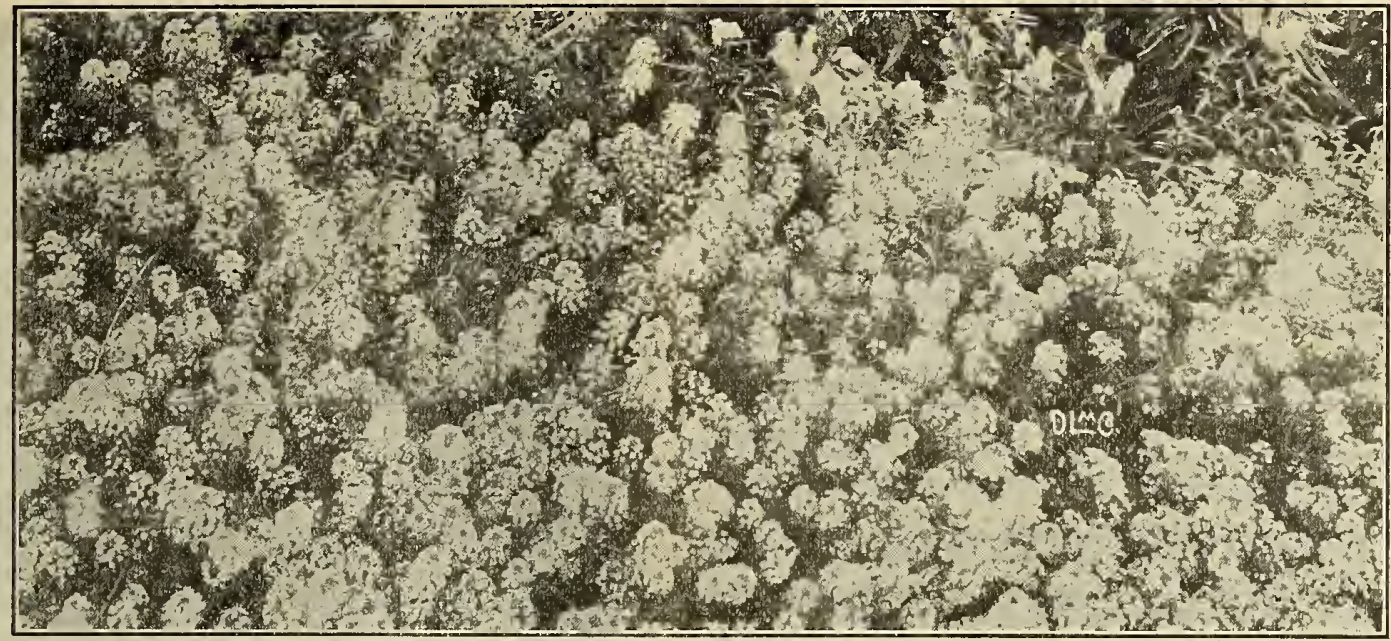

Sweet Alyssum

\section{PERENNIAL PLANTS}

The Hardy Garden is a joy forever. Unlike Annuals, which have to be sown anew every year and die with the first touch of Winter, the Perennial Garden awakens to life with earliest Spring sunshine, and gladdens the heart season after season, needing comparatively little care once the plants are well established. We give belotv a list of the best known and most satisfactory hardy perennials.

The plants we furnish are all sturdy, well rooted stock, which will grow on at once, flowering the same season.

ACANTHUS Mollis (Bear's Breech). A majestic plant of highly ornamental effect. Large heart shaped leaves. The rose colored flowers resemble the bloom of Snapdragon.

ACHILLEA (Perry's White). Ht. $3 \mathrm{ft}$. A great improvement on the well-known "Pearl," the individual flowers being twice as large and completely double, entirely concealing the center of flower. The clear white sprays are excellent for cutting.

ANCHUSA Italica Dropmore (Novelty). $4 \mathrm{ft}$. Large, fleshy leaves from the center of which grows the tall flower spike bearing on its many branches loose clusters of large Forget-me-not-like flowers of the rare gentian blue tint. Each, 35 ets.; doz., $\$ 3.25$.

A. Myosotidifiora (Novelty). I ft. Splendid for rockery or border. The compact growing plant, is literally covered with vivid blue blossoms most striking and attractive. Each, 35 cts.; doz., $\$ 3.25$.

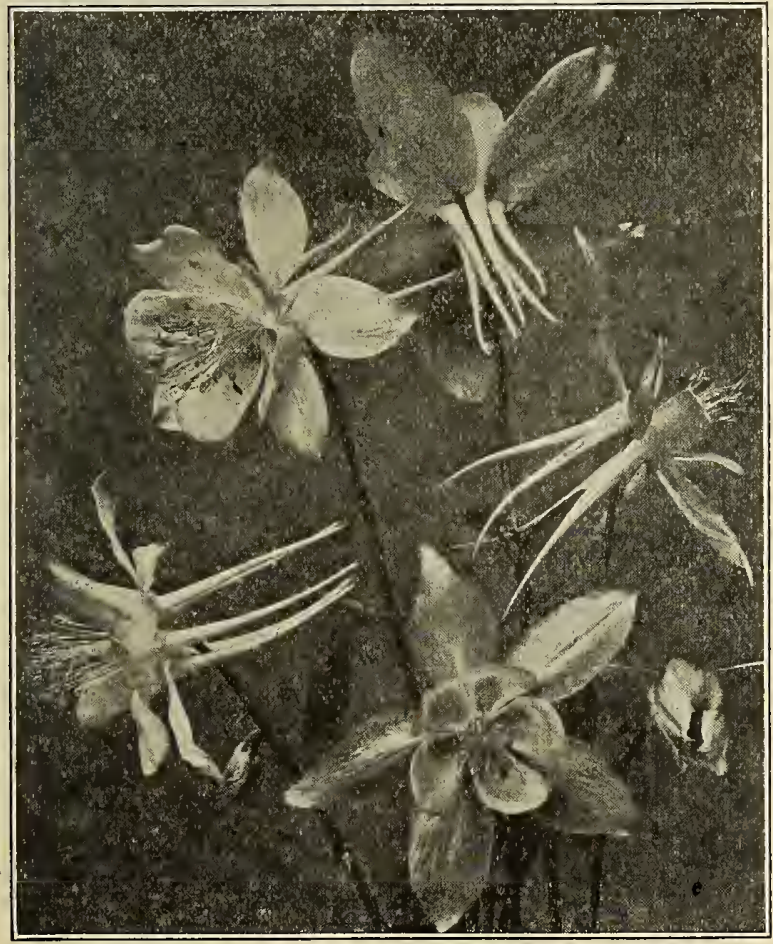

Aquilegia

ACONITUM (Monk'shood). $21 / 2$ to $3 \mathrm{ft}$. tall with shiny green foliage and hood-like flowers, borne in quantity on long, stiff stems.

A. Napellus. Well known and most reliable. Blooms in June. Dee

A. Wilsoni (New). Introduced from Northern China. A strong stately plant, 4 to $5 \mathrm{ft}$. high with large violet blue flowers. Prefers partly shady situations. Each, 50 cts.; doz., $\$ 5.00$

AGROSTEMMA Coronaria (Mullein Pink). Ht. $2 \mathrm{ft}$. Foliage bright silvery green; the many branches terminate in bright red flowers.

AL YSSUM Saxatile Compactum (Gold Dust), I ft. One of the best and showiest Spring flowering plants for borders, rockeries, or in masses, creating a spot of richest gold.

ANEMONE (Windflower). A splendid hardy plant. Dark green leaves, large snow white saucer shaped flowers with golden centers.

A. Japonica Rosea. Delicate rosy pink; very floriferous.

A. Loreley (New). Large semi-double rose pink flowers. Each, 40 cts.; doz., \$4.00.

ANTHEMIS Kelway. I5 ins. This hardy yellow Marguerite is one of the best Summer flowering perennials, succeeding in poorest soils, blooming till heaviest frosts.

AQUILEGIA (Columbine). 2 ft. Always desirable. Graceful fern-like foliage; slender stalks crowded with the many colored blossoms like gay butterflies. Flourishes in sunny spots as well as in moist, shady situations.

A. Chrysantha. Golden yellow.

A. Cærulea. Beautiful combination of blue and white

A. Canadensis. Our native Aquilegia. Red and yellow.

ARABIS Alpina (Rock Cress), 6 ins. The very earliest of all perennials to bloom covering as winter's snow leaves, the soil with its carpet of snowy,

ARGEMONE Pltyceras (Prickly Poppy). See description page oo.

ARMERIA Alpina (Alpine Thrift). Ideal rock plant, or for edging borders, for covering steep inclines or terraces, the deep growing roots holding the soil, the grass like foliage remaining all Winter. Flowers in umbels on stiff slender stems. Color rose pink to ruby red.

ARTEMISIA Lactifolia. Stately plant, 4 to $5 \mathrm{ft}$, high, producing in late Fall masses of milk white fragrant flowers; most valuable at a time when flowers are growing scarce.

HARDY ASTERS (Michaelmas Daisies). Among all Fall blooming plants this is surely one of the most grateful, hardy and desirable, growing without any care, in sunshine or shade, in any kind of soil. They comprise a large range of beautiful color tints and are unexcelled as cut flowers, having excellent keeping qualities.

A. Glory of Cornwall. The most beautiful and effective of all. Flowers semi-double and double. Color the most tender rose.

A Novo Anglix. Stout hairy stems, 3 to $5 \mathrm{ft}$ high. The large violet purple flowers are borne in large clusters.

A. Climax (Novelty). A gem. 4 to $5 \mathrm{ft}$. high, literaly smothered in large light lavender blooms, in pyramid form. Each, $60 \mathrm{cts} . ;$ doz., \$6.00.

- A. Glen Eyre. A wonderful novelty, native of Colorado. Glistening bright pink shading to lilac rose; growth very strong and upright yet heavily branched. Each, 75 cts.

A. Esther. Graceful sprays of blush rose starry flowers. Most beautiful. A. White Queen. $3 \mathrm{ft}$. A mass of snowy white blossoms,

Do not fail to plant these lovely hardy Asters. Plant them in the border. Plant them in masses or as single specimens.

ASPERULA Odorato. Grown for its fragrant white flowers and foliage. When dried these have the delicate fragrance of new mown hay. 


\section{PERENNIAL PLANTS-Continued}

BOCCONIA (Plume Poppy). Stately plant $6 \mathrm{ft}$. high, fine for shrubbery or as specimens on lawn. Large heart shaped leaves, reverse silvery gray. Pretty flower like plumes of a clear creamy color.

BOLTONIA Asteroides. Late flowering shrubs, 6 to $8 \mathrm{ft}$. high, bearing masses of daisy like white flowers. Most useful for cutting.

B. Latisquama. Same as above, except that the color is rosy pink to lavender. Most charming and useful in late Fall.

BUDDLEIA (Butterfly Plant). One of the most desirable Summer flowering shrubs; begins blooming in July till frost.

B. Globosa (Orange Tree). Novelty. 8-ro ft. Very showy with bright orange ball-like flowers.

CAMPANULA (Bell Flower). A splendid group of old garden favorites. C. Medium. (True Canterbury Bell). Pure white, pink, lavender and purple.

C. Persicifolia (Peach Bells). Deep blue or white.
C. Pyramidalis (Chimney Bell Flower). 3 to $5 \mathrm{ft}$. Blue flowers disposedlin long panicled racemes. Very showy.

CENTAUREA Montana (Perennial Cornflower), $2 \mathrm{ft}$. Thrives anywhere. Large deep blue or white flowers.

CERASTIUM Tomentosum (Snow in Summer). Silvery fur coated foliage. White flowers.

HARDY GARDEN CHRYSANTHEMUMS. One of the finest Autumn flowers. Such a wealth of colors, such ease of culture, such lasting qualities after being cut

C. Alaska. Glistening white flowers, golden disk. Blooms continually.

C. Shasta Daisy. Same as Alaska, but of stronger growth

C. Leucanthemum fl. pl. (Novelty). I8-24 ins.

DOUBLE HARDY MARGUERITE. Double resembling a snow white double Pyrethrum. Long wiry stems. When it shows signs of seeding,
cut back the stems; it will bloom again later. Each, 50 cts.; 3 for $\$ 1.35$.

BABY POMPON or Button Chrysanthemums. Flowers small, like button are produced in great abundance in clusters. Colors of the widest range, from pure white to deep maroon, rose, yellow, orange, bronze, dark red. Order by "color wanted."

COREOPSIS Lanceolata. Golden yellow flower of large size like Golden Marguerites. Blooms all Summer.

DELPHINIUMS (Hardy Larkspur). One of the most glorious Garden plants. Indispensable wherever hardy plants are seen.

D. Belladonna. 3 to $4 \mathrm{ft}$. The finest of all. Softy sky blue flowers.

D. Formosum. $3 \mathrm{ft}$. Dark blue with white eye. Each, 30 cts.; doz. $\$ 3.00$.

D. English Hybrids. A selection of the choicest sorts grown, shading from almost white through all tints of blue to deep purple. Each, 30 cts.; doz., \$3.00.

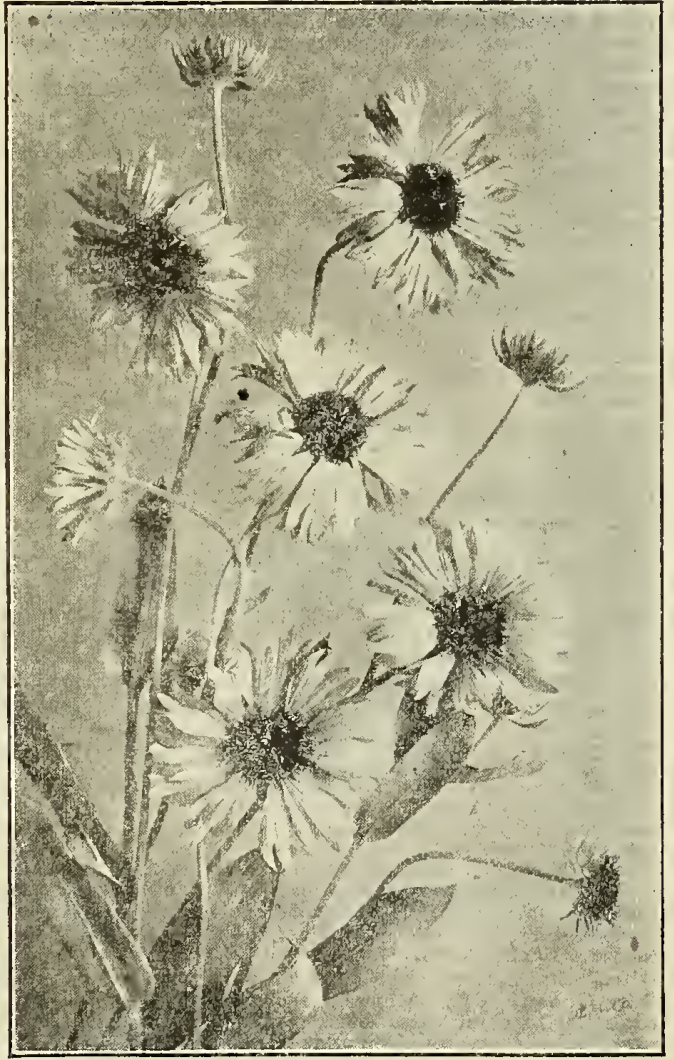

Gaillardia

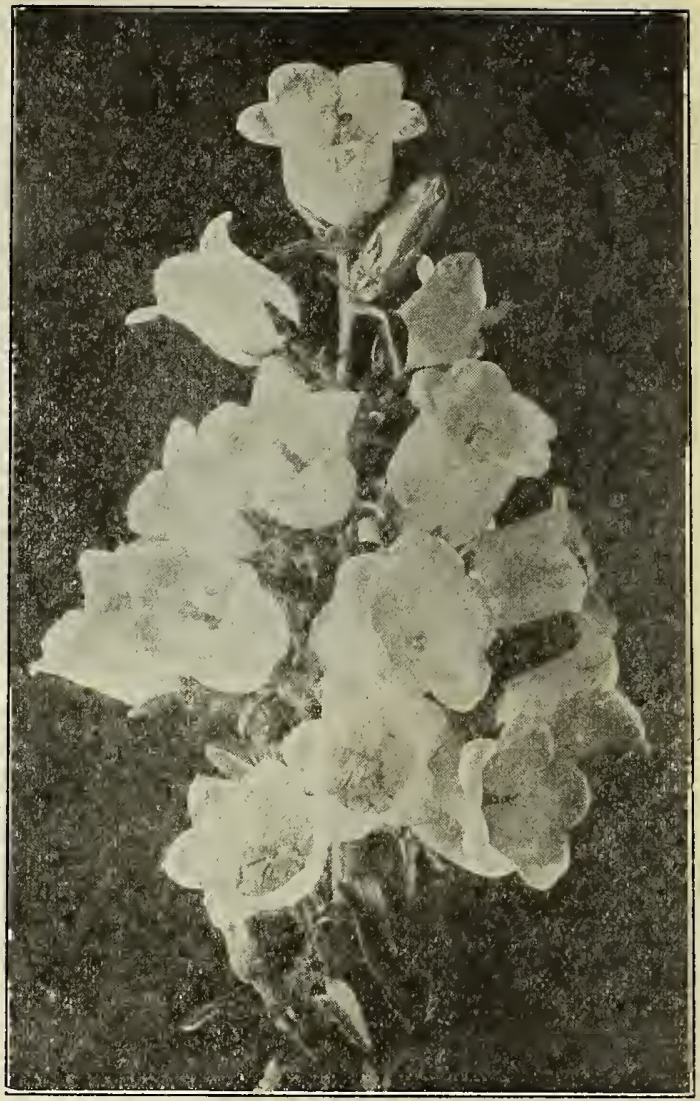

Campanula

D. Chinense. $2 \mathrm{ft}$. Fine cut feathery foliage, stems thin and wiry; blue and white flowers. Each, 30 cts.; doz., \$3.00.

DIANTHUS Barbatus (Sweet William). Improved strains. Immense flower heads in brightest colors, white, rose, crímson, scarlet.

D. Plumaris (Pheasant's Eye Pink). Fragrant and beautíful; in mixed

D. Plumaris. (Mrs, Simpkins) (New). Beautiful white. Double flowers. Each, 50 cts.; doz., \$5.00.

DICTAMNUS Fraxinella. (Purning Bush or Gas Plant). Rosy crimson flowers. $3 \mathrm{ft}$. Loves dry soil and sunshine.

DIGITALIS (Foxglove). 3 to $4 \mathrm{ft}$. Fine for semi-shady places. Thrives anywhere.

D. Gloxiniaflora. Beautiful species with white or pink tubular flowers spotted and marked like a Gloxinia.

D. Grandifiora Ambigua. Pale yellow with dark veining.

DORONICUM (Leopard's Bane). Large bright yellow flowers in early Spring. Very effective and fine for cutting.

EDELWEISS. (See description page 36 ).

EUPATORIUM. The pure white flowers, which appear in masses, resemble Ageratum.

E. Coelestinum. A beautiful form with light blue flowers.

FUNKIA (Day Lily). One of the first to peep through the soil at the approach of Spring, developing its broad leaves rapidly, followed by bell-like lovely flowers.

F. Subcordata Grandiflora (Corfu Lily). Glaucous pale green leaves: pure white lily-like flowers; deliciously fragrant.

F. Variegata. Bright green crinkled foliage with white variegations Charming pale lílac flowers.

GAILLARDIA (Blanket Flower). The large daisy-like flowers are crimson and gold, orange and vermilion; bloom in great number all Summer.

GAURA Lindheimeri (Waving Bullerfly). From out the bright green leaves, which spread on the ground, arise several smooth wiry stems to a height of 4 to $5 \mathrm{ft}$., on which hang loosely large, white single blossoms resembling white butterflies swinging on the stalk.

GEUM Coccineum (Mrs.Bradshaw) (Novelty). The main stem branches near the top, each shoot ending in a large double Ranunculus-like flow er Color rích blood red, showing when fully open a golden disk. Most beautif ul.. Each, 30 cts.; 3 for 80 cts.

G YPSOPHILA Paniculata (Baby's Breath). $3 \mathrm{ft}$. Cloud-like feathery fosiage, innumerable tiny pure white double flowers. Beautiful in connection with other flowers, for bouquets, vases, etc.

HELENIUM (Sneezewort). 4-5 ft. Autumn's Golden Glory. Stout tems bear umbels of daisy-like flat flowers, all open at one time. 


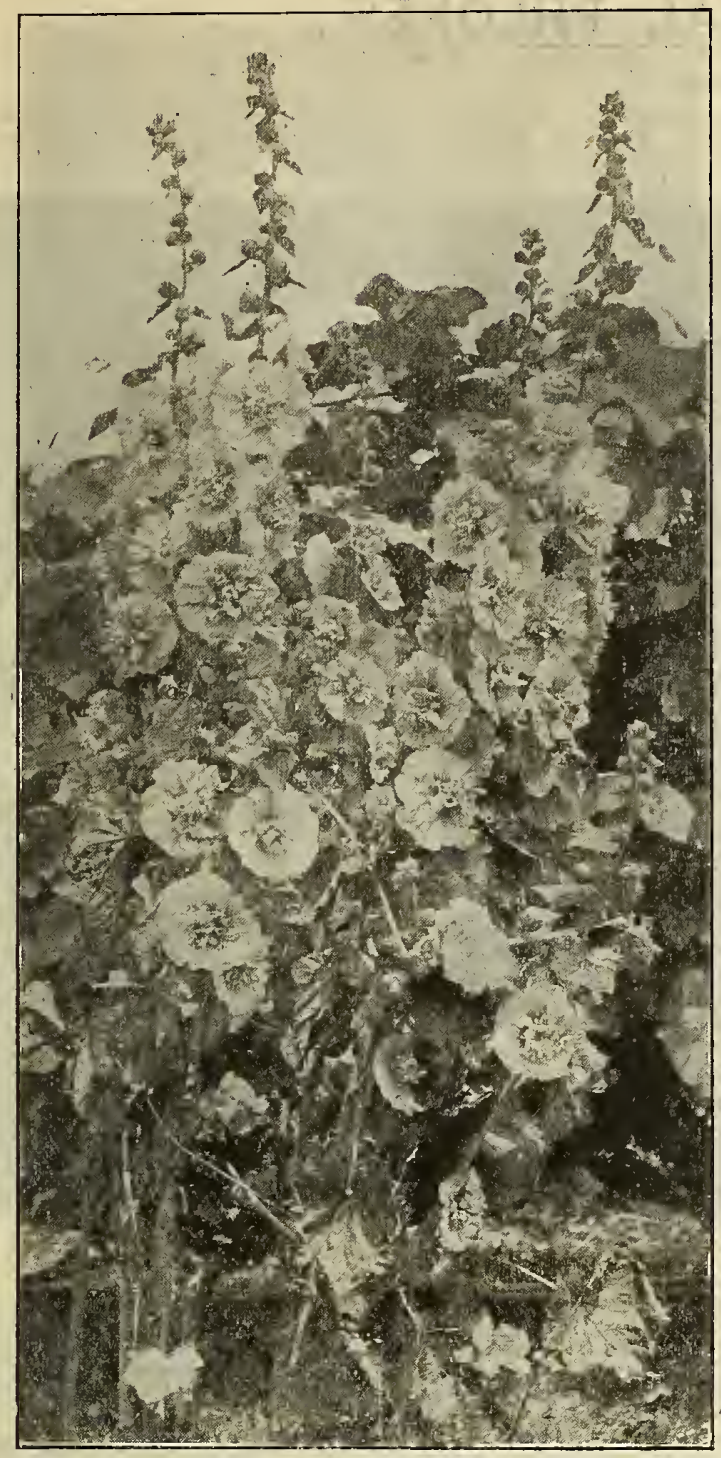

Hollyhocks

PERENNIAL PLANTS-Continued

HELIANTHUS (Sunflower):

H. Orgyalis. 6-8 ft. Stately plants; soon form large clumps. The narrow drooping foliage is most attractive. The branches grow in different directions giving the plant the appearance of a floral fountain covered with its bright yellow flowers.

HEMEROCALLIS (Yellow Day Lily). These are without doubt among the finest for ordinary garden culture. They thrive anywhere, eithe in sun or partial shade. The flowers are produced on tall spikes and in sun or partial shade. The flowers are produced on tall

H. Flava (The Old Fashioned Yellow Day Lily).

H. Gold Dust. Bright Indian Yellow, buds and reverse of petals bronzy gold.

H. Aurantiaca Major. Large trumpet shaped flowers. Very showy. F. Queen of the Miay (Novelty). 3-5 ft. Immense golden to apricot yellow flowers in great profusion, Each, 40 cts.; 3 for $\$ 1.00$.

HEUCKERA (Alum Root). Pretty for rockeries and edging. Graceful wiry stems, 18 ins. high, bearing airy panicles of coral red scarlet flowers throughout Summer.

HIBISCUS (Mallow). Giant plants, 4-6 ft. With wide open flowers.

H. Meehani (Meehan's Marvels). 6-8 ft. Flowers 6-7 ins. across. Colors rose to bright crimson. Each, 40 cts.; 3 for $\$ 1.00$.

FOLL YHOCKS. Standing in rows, like well-drilled soldiers, they are most valuable planted along roadways, to hide fences or garden walls Their colors are varied like the rainbow. Order any color desired, either single or double.

IBERIS Sempervirens (Evergreen Candytuft). I2 ins. Flat heads of densely clustered snow white blossoms, in early Spring. Foliage remains green till late Fall.
INCARVILLEA Delavayi (Hardy Gloxinia). New plant from China. $3 \mathrm{ft}$. Pale green foliage $2 \mathrm{ft}$. long. Flowers like Gloxinias, of a bright rose. Very fine. Each, 20 ets.; 3 for 75 ets.

LATHYRUS Latifolius (Hardy Everlasting Pea). Beautiful climber for trellis or fences. Flowers like sweet peas, white, rose or red. Order by color. Each, 35 ets.; doz., $\$ 3.00$.

LAVENDULA (True English Lavender). Highly fragrant blue flowers. When dried these perfume any place they are put. Each, 30 ets.; doz., $\$ 3.00$.

LIATRIS (Blazing Star, Kansas Gay Feather). $4 \mathrm{ft}$. Large showy spikes with rosy purple flowers.

LOBELIA Cardinalis. A gorgeous plant. Loves moisture. The dazzling scarlet flowers attract attention anywhere.

LUPINUS Polyphyllus. 3-4 ft. Stout stems around which the Pea like flowers sit closely. Very robust. Blooms early Summer. Colors white, blue, rose, yellow. Order by color.

LYCHNIS Chalcedonica (Maltese Cross). $2 \frac{1}{2} \mathrm{ft}$. White or scarlet flowers in large heads.

cts.; doz., \$3.25. Flos Cuculi (Cuckoo Flower, Ragged Robin). I8 ins. One of the few perennials which flower continuously throughout Summer. Wiry stems with numerous branches, each terminating in several bright rose fringed or tassel-like flowers.

MERTENSIA Virginica (Blue Bell). Drooping panicles of bright blue flowers which are rose pink in the bud state.

MONARDA Didyma (Bee Balm, Bergamot). Highly fragrant flowers, of dazzling scarlet. Foliage aromatic. $21 / 2 \mathrm{ft}$.

MYOSOTIS (Forget-me-not), Differ from annual sorts in being perfectly hardy and increasing rapidly.

M. Alpestris Victoria. Bright blue flowers.

M. Palustris Grandiflora. Especially fine for wet places. Large blue flowers with golden disk.

GNOTHERA Missouriensis (Evening Primrose). Trailing variety with large golden yellow bloom.

o. Speciosa Rosea. Showy, bright rose flowers.

PACHYSANDRA Terminalis (Japanese Spurge). (Great Novelty). This plant has only recently come to our shores and its great value is just beginning to be appreciated. The creeping roots send up freely numerous leaf stalks 8-1o ins. high. The deep green leathery foliage surrounds the stems in whorls, perfectly covering the ground. It is the only plant known to exist which will thrive under Pine or other conifers. The foliage being Evergreen remains so through the Winter and hence is as valuable as Euonymus. It withstands the severest Winters, is free of insects, will grow anywhere and wherever unsightly bare places are to be covered this new plant is invaluable. It is as yet rare. Order early. Each, 30 ets.; doz., \$2.50.

PENTSTEMON (Beard's Tongue). $3 \mathrm{ft}$. On leafless wiry stems. The tubular flowers in bright rose, white or scarlet, give. a most charming effect. Loves sandy soil and plenty of moisture in summer.

P. Digitalis. White flowers with purple throat.

PHYSOSTEGIA Virginica (False Dragon Head). $4 \mathrm{ft}$. Blooms in August at a time when few perennials flower. Flowers facing upward resemble Snapdragon. Colors light rosy lilac to purple.

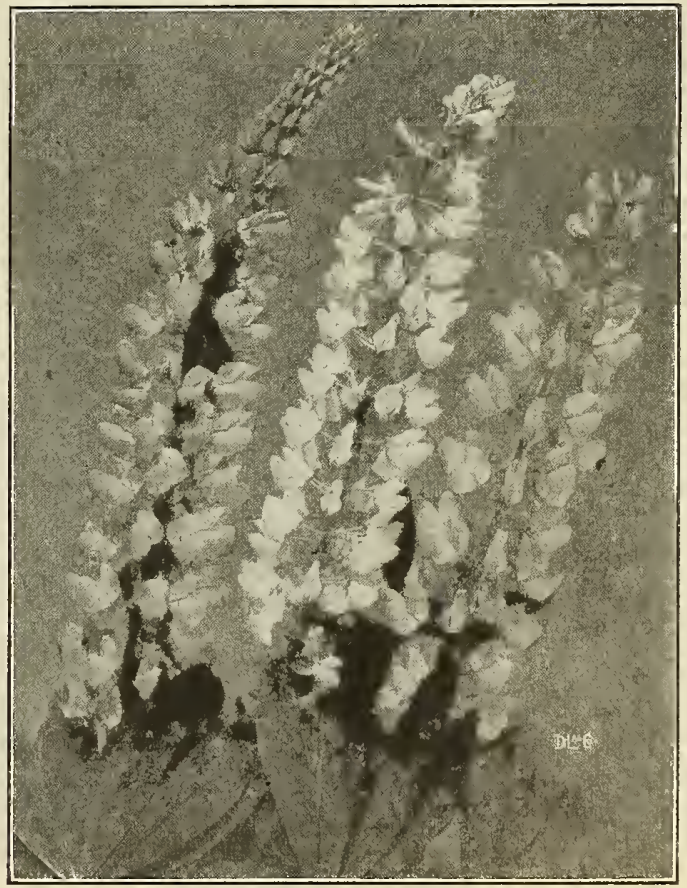

Lupinus 


\section{HARDY PERENNIAL PHLOXES}

(Phlox Decussata)

Undoubtedly one of the MOST popular and satisfactory of all hardy garden plants. All colors and tints are represented, many having a delicious fragrance. For cutting, the large trusses of flowers give splendid effects. They are, moreover, of the EASIEST culture, succeeding in almost any soil enriched with well decomposed manure and given a fair amount of moisture. Remove the first spikes of bloom as soon as over and give the plants a good soaking; they will produce a second supply of flowers, continuing the display until late Fall. These later blooms are of ten finer than the earlier. We present a carefully selected list of the VERY CHOICEST sorts.

*ELIZABETH CAMPBELL. Bright salmon pink, with dark crimson eye. Entirely new and a much wanted shade.

*EUROPE. Large truss, white with crimson eye.

*VICKING. Many branched pyramidal heads; soft salmon rose.

*WDAR. Light reddish violet, very large white center.

*RIVERTON JEWEL. Lively mauve rose, carmine red eye.

*ALBION. Immense truss, pure white, faint red eye.

*Each of these six Newest Hardy Phloxes, 25 cts.; doz , \$2.50. Hardy Phlox in other sorts or mixed. Each, 20 cts.; doz., \$2.00.

BACCHANTE. Very tall; bright rose carmine eye.

EUGENE DANZANVILLIERS. Very large; rosy lilac white eye.

*MADAME BUChNER. The finest white sort in existence. Large individual flowers in gigantic trusses. Each, 30 ets.; doz., \$3.00.

H. MURGER. White crimson center.

JEANNE D'ARC. Late flowering white.

LA VOGUE. Clear silvery rose.

*L'EVENEMENT. Magnificent orange scarlet overlaid rose. Each, 30 ets.; doz., $\$ 3.00$.

MME. PAUL DUTRIE. Most delicate rosy lilac-like Cattleya orchid; the panicles are enormous.

PANTHEON. Brilliant salmon rose.

R. P. STRUTherS. Rosy "carmine claret eye. Extra fine.

COQUELICOT. Brilliant scarlet.

*GEFION. A new color in Phloxes; tender Peach blossom pink with bright rose edge. Each, 30 cts.; doz., $\$ 3.00$.

PHLOX Suffruticosa (Miss Lingard). Remarkable bloomer, producing two to three crops during season. Grand for cutting. Tall growing. Flowers are pearly white with pink eye.

PHLOX Subulata (Creeping Phlox). This forms thick mats entirely covered with rose flowers. Splendid for the rock garden or for carpeting bulb beds.

PLATYCODON Grandiflora (Chinese Bellflower). I8 ins. Large bellshaped flowers like Campanulas.

P.!Mariesi. Clusters of deep green foliage, large bell-like flowers, white or blue, at the end of slender wiry stems.

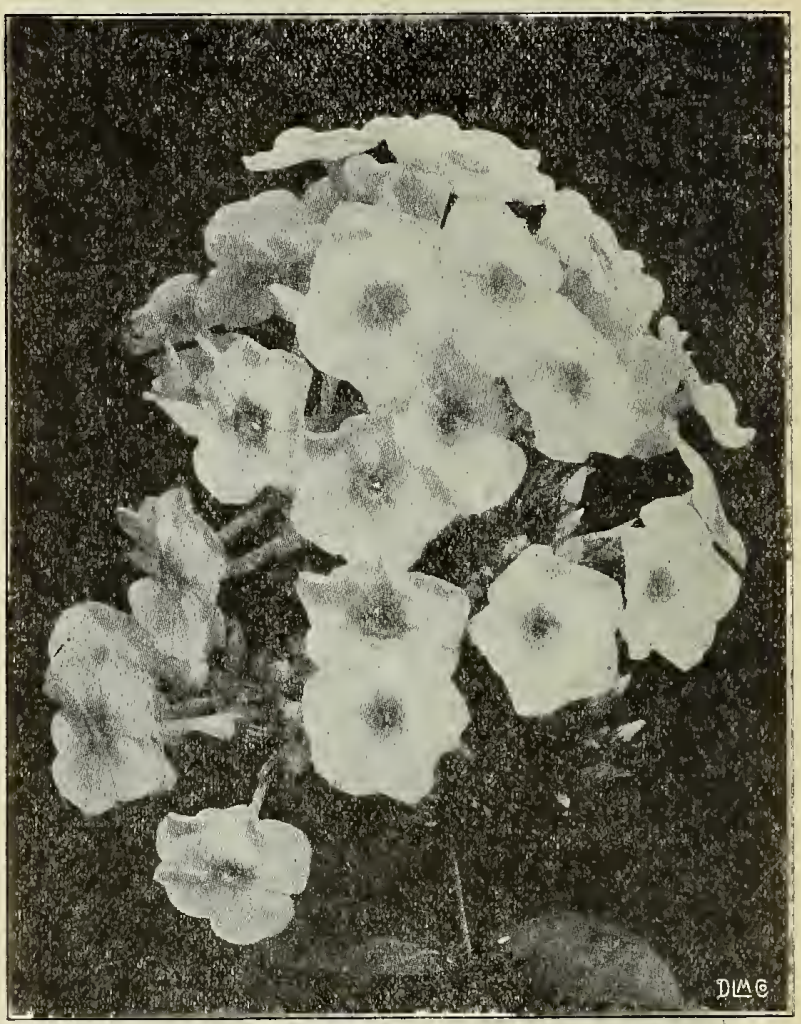

Phlox H. Murger

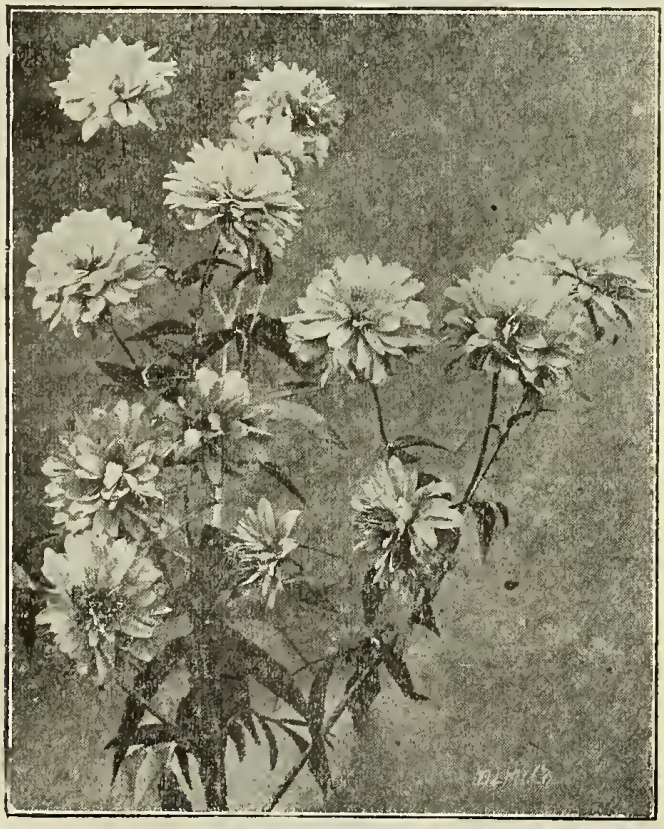

Rudbeckia Golden Glow
ORIENTAL POPPIES. These are truly the aristocrats of the garden. The beautiful glaucous green foliage and the immense bloom are so inagnificent that a sight of a clump of them is a thing of splendor. They lntagnificent that a sight of a clump of them is a thing of splendor. They
flower in June, dying back after flowering but reappear again in late September. Pot grown plants are better to grow on than field roots, as they will flower first season. We favor only pot grown plants which we offer from 4-in. pots, extra strong, color to your choice; white, scarlet, rose, orange, apricot, cerise or crimson. Each, 25 cts.; doz., \$2.50. Mixed colors, each, 20 ets.; doz., $\$ 2.00$.

ICELAND POPPIES. Ideal for rock gardens or edging. Fern-like foliage, the daintiest of flowers, on slender wiry stems, in the most gorgeous coloring.

HARDY PRIMULAS. The most charming Spring flowering plants. Unexcelled for effect in protected nooks or for edging of shady borders. Early Fall planting is the most suitable for these lovely Spring blossoms. Give a rich soil and light mulching through Winter.

P. Veris (True English Primrose or Cowslip). Golden yellow clusters.

P. Beesiana. Rare sort; velvety purple. Each, 45 cts.; doz., \$4.25.

P. Bulleyana. Golden veliow suffused deep orange, in closely set whorls on strong stems, I5 to I8 ins. high. Each, 35 ets.; doz., \$3.25.

PYRETHRUM (Persian Daisy). $3 \mathrm{ft}$.

P. Roseum Hybrids. Thrive anywhere and flower con tinuously throughout season. Single or double, in colors white, rose, naroon, crimson, mixed.

ROMNEYA Coulteri (Matilija Poppy, The Dream of the Desert). A flower looking as if made of tine finest white silk crepe, wrinkled and fluted petals surrounding a bright golden disk rising on tall stems from a cloud of soft greyish green foliage, all fern-like and beautiful. Grows 6-7 ft. high. Protect in Winter with brushwood. Strong plants. Each 75 cts.

RUDBECKIA (Cone Flower). One of the most showy Autumn flowering plants.

R. Golden Glow. Masses of golden yellow blossoms. Thrives under any conditions.

R. Purpurea Echinacea. Giant purple Cone flower. Showy reddish purple flowers with a prominent cone-shaped brown center. 


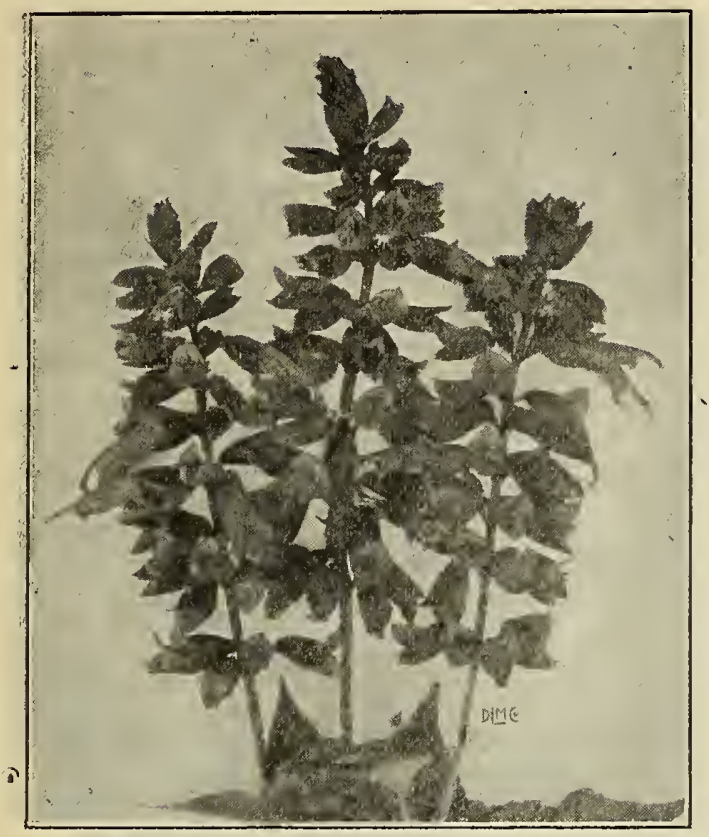

Salvia

\section{HARDY PERENNIAL PHLOXES--Continued}

SAXIFRAGA (Rock Foil). Handsome broad leaved plants. I2-I 5 ins. high; long graceful sprays of flowers white and rose.

SALVIA (Sage). Very pretty orchid-like flowers. The foliage is used for flavoring in kitchens.

S. Azurea Grandiflora (Rocky Mounlain Sage). Has bright azure blue

s. Greggii. A magnificent, new, ever-blooming, extremely hardy shrub from the cold arid mountains of Western Texas. It flourishes and blooms profusely in the hottest, driest weather. The flowers are a soft cerise crimson, like American Beauty Roses. Each, 50 cts.

SEDUM (Slonecrop). Succulent plants of varied character. Dwarf sorts are invaluable for covering stone work or filling out crevices. They also make an excellent ground cover for very dry places. The taller sort are fine for border planting and edging.

S. Acre (Wall Pepper). Light green foliage, yellow flowers.

S. Album. White flowers, creeping foliage.

S. Spectabile. Brilliant large flat heads of rose crimson.

STATICE (Sea Lavender). Excellent for seaside planting.

S. Latifolia. The finest of them all. Many branches, like candelabra, covered with miniature lavender flowers set close to the branches, having the appearance of a misty blue cloud. The foliage takes on Autumn tints, remaining fresh all Winter. The flowers keep in a dried state for many months.

STOKESIA Cyanea (Cornflower A sler). $21 / 2 \mathrm{ft}$. A charming well-known Perennial. Cornflower-shaped blooms in tender blue or white.

S. Rosea (New). Rose variety. Each, 50 cts.; doz., \$5.00.

THALICTRUM Adiantifolium (Meadow Rue). Purplish stems; foliage like Maidenhair ferns; flowers white or rosy purple.

TROLLIUS (Globe Flowor). Bright yellow globe shaped flowers like Giant Buttercups. Stems are leafless, stout and wiry. Foliage lies close to the ground.

VERONICA (Speedwell). $3 \mathrm{ft}$. Most popular and favorite.

V. Amethystina. Amethyst blue flowers.

V. Spicata. Loves sunshine. Clear blue flowers with purple stamens. V. Alba. White flowers.

V. Rosea. Rose pink.

VINCA (Periwinkle, Trailing Myrlle). Dwarf evergreen; excellent to cover shady ground. Bright blue flowers.

VIOLA Cornuta (Tufted Pansies). In white, yellow, purple. "Order per colors."

YUCCA Filamentosa ( $A$ dam's Needle). One of the most striking ornamental plants. A good soil is necessary to produce its heavy stems, $6-8 \mathrm{ft}$. tall, bearing from 50 to 200 oval creamy white blossoms 2 ins. long. Foliage is evergreen. Strong plants. Each, 25 cts.; doz., \$2.50. Extra strong clumps, each, 50 cts.; doz., \$5.00.

LILY OF VALLEY CLUMPS. Plant as soon as ground can be worked. The flowers appear in May, continuing until hot weather sets in. These clumps increase rapidly, producing every Spring a mass of the dainty, exquisitely fragrant flowers. Strong clumps, each, 25 cts.; doz., $\$ 2.50$; per $100, \$ 20.00$.

The price for all "Hardy Perennial Plants" on this list is uniformly 2o cts. each; $\$ 2.00$ per dozen-unless otherwise noted. The dozen price applies only where at least six of a kind are taken.
HARDY VINES and CLIMBERS

ACTINIDIA Arguta. Very vigorous growth. Glossy green foliage, whit flowers with purple center, followed by clusters of edible fruit. Can
be eaten raw, pickled, or made into jelly. Each, 50 cts.; doz., \$5.00.

AKEBIA Quinata. Rapid climber of dense growth, with rich cloverlike foliage, pendulous clusters of dark purple fragrant flowers. Doe well in sunny places. Gives dense shade. Strong plants 40 cts.

AMPELOPSIS Quinquefolia (Virginia Creeper or Woodbine). Broad, deeply cut foliage, which assumes gorgeous tints in Autumn. Each, 35 cts.; doz., \$3.50.

AMPELOPSIS Veitchii (Japanese or Boston Ivy). One of the most useful and charming vines, known by every one. The very best for covering andls, to which it clings by means of little rootlets. The foliage assumes the most glorious Autumn tints in Fall. It will completely cover buildings and stone walls in short time.

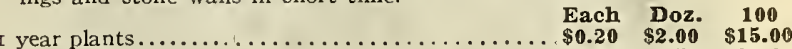

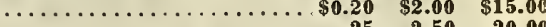

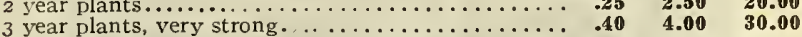

APIOS Tuberosa (Tuberous Rooled Wistaria). Closely resembles the common Wistaria in foliage and flowers. The flowers are a deep rich purple and deliciously fragrant. Perfectly hardy. Plant two or three bulbs rather closely together to produce a more striking effect. Each tuber, 10 cts.; 3 for 25 cts.

ARISTOLOCHIA Sipho (Dulchman's Pipe). A very strong growing vine with showy, broad heart shaped leaves, overlapping each other, making a perfect screen. The green and violet flower, resemble a Dutchman's pipe. Each, \$1.00; doz., \$10.00. Smaller plants, each, 75 cts.; doz., $\$ 8.00$.

BIGNONIA Radicans (Trumpel Flower). Attains $50 \mathrm{ft}$. and /over in one season. Large trumpet shaped flowers, dark red with orange throat. Free blooming and very showy. Strong plants 50 ets.; doz., \$5.00.

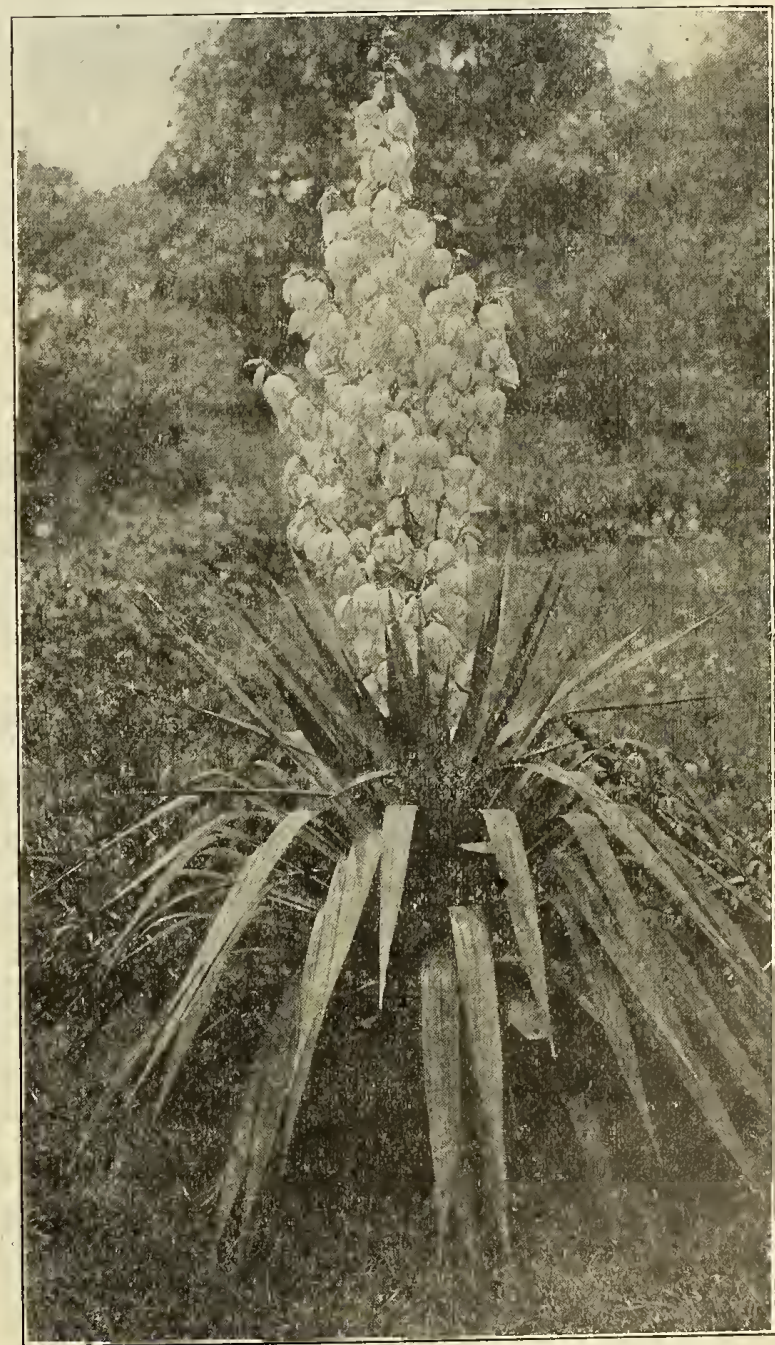

Yucca Filamentosa 


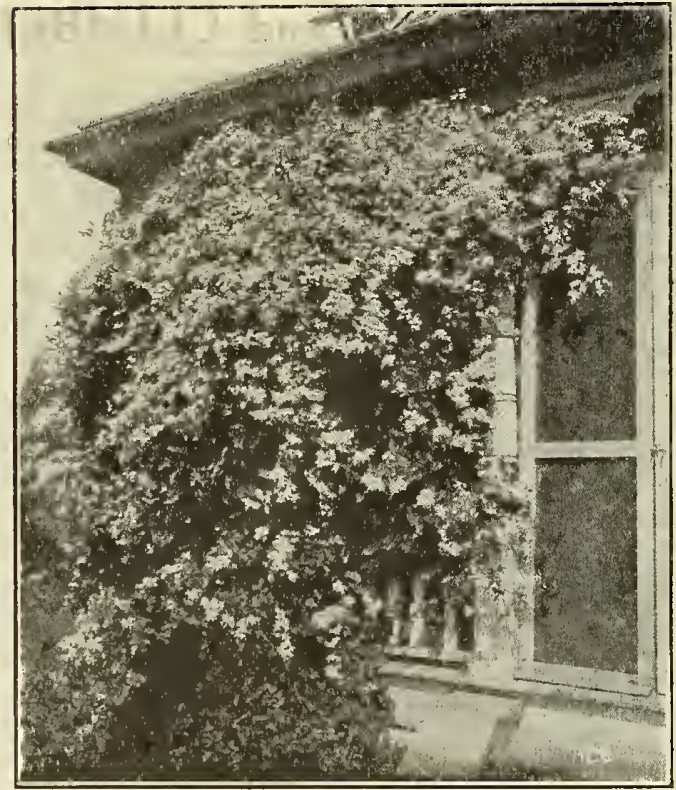

Clematis Paniculata

\section{HARDY VINES and CLIMBERS-Continued}

CELASTRUS (Bittersweet). A rampant climbing shrub, with luxuriant green foliage, covered in Fall witb bright yellow fruits, which open and disclose the scarlet seeds. This and the native $C$. Scandens are most valuable for covering banks ot tocks. Each, 40 cts.; doz., $\$ 4.00$.

CINNAMON VINE (Chinese Yam). Splendid hardy climber of amazingly rapid growth; bright green heart-shaped flowers and white cinnamon scented flowers.

CLEMATIS. Given a moist loamy soil and sunshine, these thrive anywhere, coming up every Spring, once established.

C. Henryi. Immense broad

C. Jackmanni. One of the very best. Deep velvety purple.

*C. Madame Edouard Andre. The richest dark red sort.

${ }^{*}$ C. Siegboldi. A beautiful, tender lavender shade.

C. Duchess of Edinburgh. Double white, fragrant.

* Madame Baronne Vieillard. Finest satiny rose pink.

All Clematis listed and marked with $*$ are uniformly in price, 50 ets. each, $\$ 5.00$ the dozen. All are strong plants, flowering the first season. C. Paniculata (Virgin's Bower). Thrives luxuriantly everywhere. Quickly covers trellises, etc., with a dense mass of glossy dark green foliage, bearing later Summer masses of starry white fragrant flowers, completely hiding the foliage. Each, 25 cts.; doz., \$2.50. Extra strong plants, each, 50 cts.; doz., $\$ 5.00$.

CLEMATIS Coccinea. Flowers in wonderful profusion from June till late frosts. The flowers are bell or pitcher shaped, a brilliant coral red. Broad glaucous leaves. This vine is unique and attracts the eve with its beauty. Each, 30 cts., doz., $\$ 3.00$.

CLEMATIS Montana Rubens. This is a great novelty. Begins to flower in June, when a profusion of soft rosy red flowers are borne on the young shoots resembling the rosy Japan Anemones. Each, 75 cts.; doz. $\$ 8.00$.

EMERALD VINE. Of slender growth, very graceful, produced in dense masses. The foliage is broad forked or divided, of a deep emerald green with a beautiful sheen. White flowers in drooping racemes appear in great masses. Tubers are round and solid like Gladioli bulbs. Each, 15 cts.; doz., $\$ 1.50$.

IPOMQA Pandurata. Luxuriant vine, bearing great quantities of large, thick textured waxy flowers, of a rich creamy white with violet throat. Grows in any soil no matter how poor. The flowers remain open all day. Unlike other Impomøas it is perfectly hardy. The vines cover an enormous space in short time. Each, 25 cts.; doz., $\$ 2.50$.

FUDZU VINE (Pueraria Thunbergiana). Jack. and the Bean Stalk. This is acknowledged the most temarkably quick growing vine in existence. The leaves resemble those of Lima Beans and are produced in great profusion. The beautiful pea-shaped flowers appear in racemes: color is rosy purple. This vine gives the densest shade. If you desire quick shade do not fail to plant a Kudzu Vine. Strong plants, each, 25 cts.; doz., \$2.50. Extra heavy strong plants, each, 50 cts. doz., $\$ 5.00$.

LONICERA BRACHYPODA (Golden Honeysuckle). Foliage hand omely marbled with gold, of ten tinged rose when growth is young. Each, 25 cts.; doz., \$2.50.

L. B. Halliena. A charming climber of rapid dense growth with oval soft green foliage and a profusion of white and yellow flowers. One of the very finest vines for walls and trellises, arbors, etc. Each, 35 cts.; doz., \$3.50.

L. Sempervirens (Scarlet Honeysuckle). Dark green oval foliage, bright vermilion tubular flowers, appearing continually on the vines. Very vigorous grower. Each, 50 cts.; doz., $\$ 5.00$.

¿. Jasminum (Hardy Yellow Jasmine). Very fragrant, golden yellow flowers. Each, 25 cts.; doz., \$2.50.

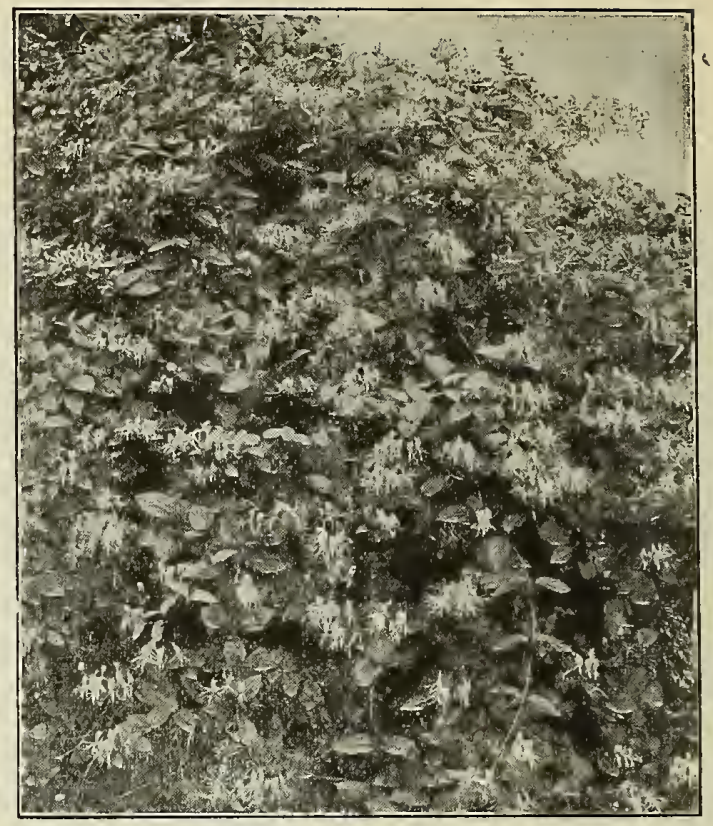

Lonicera

MADEIRA VINE. Very rapid growth. Tuberous rooted. Abundance of bright rosy flowers. Very charming and graceful. Each, 6ects. doz., 60 ets.

SCHIZOPHRAGMA Hydrangeoides (Climbing Japanese Hydrangea). The most delightful and beautiful hardy climber. It climbs rapidly, holding on by little rootlets like English Ivy. The foliage is bright green, massive, and numerous umbels of flowers appear all over the vine $\rightarrow$ The flat umbels measure 8-Io ins. in diameter, giving the whole a snowy.look, which is extremely fascinating. Each, 75 cts.; doz., $\$ 8.00$.

WISTARIA Sinensis (Chinese Wistaria). Light, pretty foliage, resembling Acacia leaves. Dense long racemes of light blue flowers witb a honey sweet fragrance. A beautiful, vine. Strong plants, each, 75 cts.; doz., $\$ 7.50$.

WISTARIA Sinensis Alba. White flowered Wistaria. Each, \$1.00; doz., $\$ 10.00$.

WISTARIA Multijuga. Superb Japanese sort. The racemes" often attain a length of $2-3 \mathrm{ft}$. Deep violet and white flowers. Each, $\$ 1.25$; doz., $\$ 12.00$.

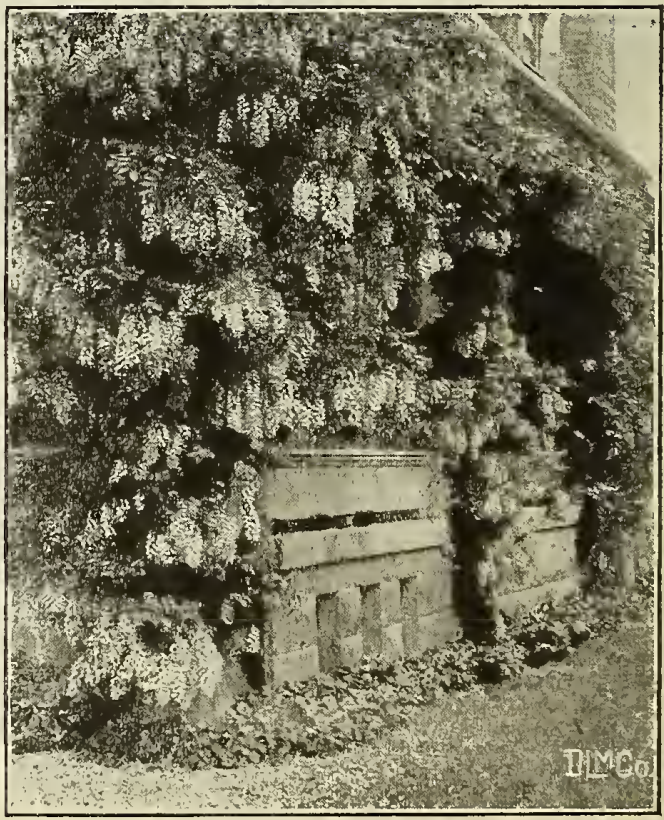

Wistaria Sinensis 


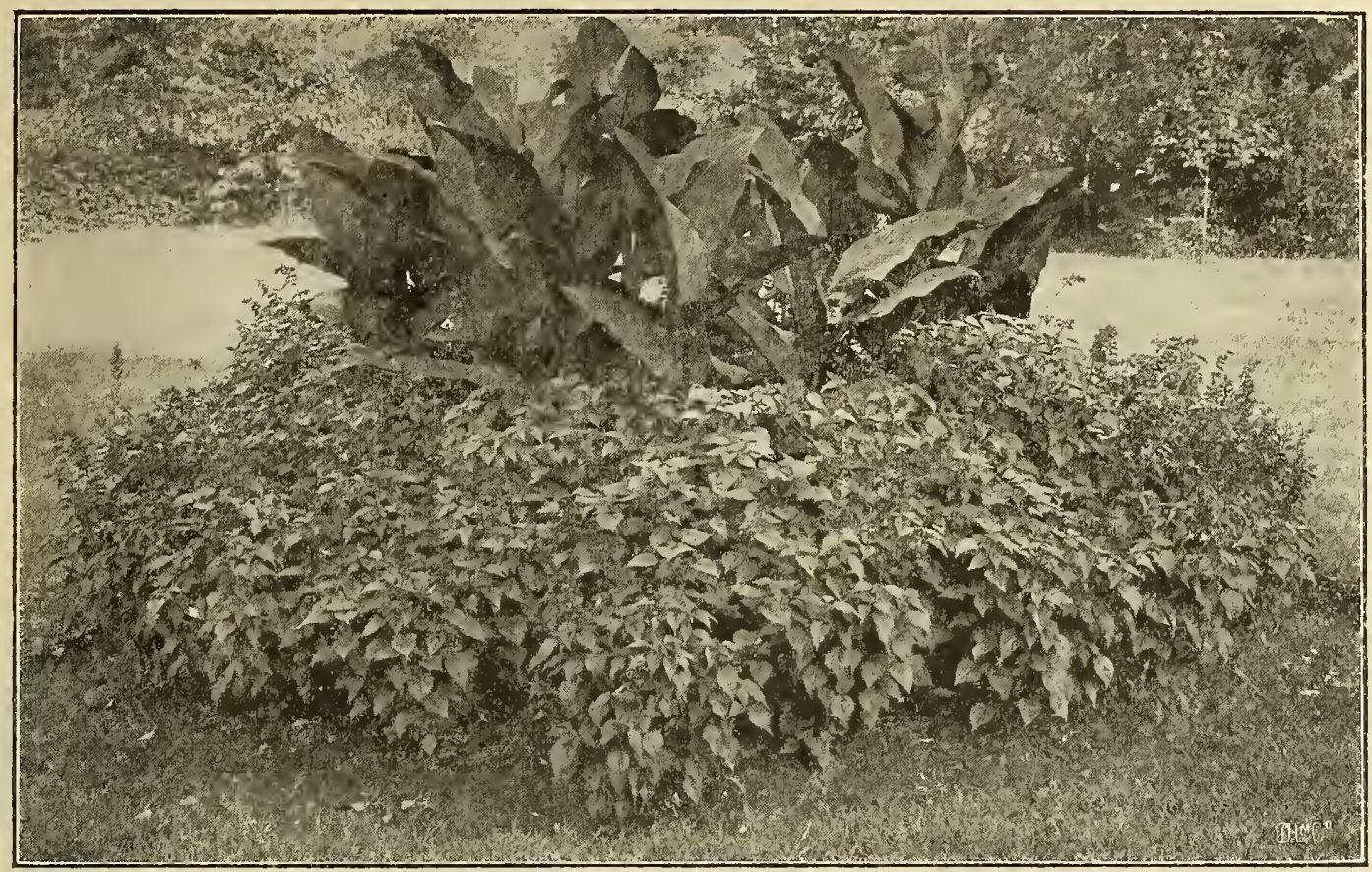

Bed of Cannas

\section{NEW and CHOICE CANNAS}

Dormant Canna roots may be started indoors during March or April, but should not be set out until the weather is settled and the ground warm, usually May or June in this latitude. When planting dormant roots do not set too deep. The eye should show a little through the ground. Plant in good, rich garden soil mixed with one-half of old, rotted stable manure. Set them about I 8 ins. apart each way. Water sparingly the first two weeks after planting; when growing freely, water liberally.

\section{PINK FLOWERING}

Mule. Eerat. Strong grower, with dark pink flowers; one of the best Height 4 to 5 feet.

West Grove. Rich coral-pink flowers that withstand rain and heat. Height $41 / 2$ feet.

Venus. One of the softest and most delicately colored sorts yet introduced. Flowers are a soft rosy pink with a pretty mottled border of creamy yellow. A very striking and beautiful variety. 4 feet.

\section{GRIMSON AND SCARLET-FLOWERING}

Charles Henderson. The standard of excellence in crimson Cannas. Height 4 feet.

Flamingo. Intense and clear crimson; flowers are of large size and borne on immense trusses in great profusion. Height 4 feet.

\section{YELLOW-FLOWERING GANNAS}

Austria. Pure canary-yellow; large, open flowers with reddish dots in center of the two inside petals. Height 5 feet.

Richard Wallace. A magnificent, large, yellow variety; green, wellshaped foliage, forming a very impressive plant. Grows about 5 feet high.

\section{ORGHID-FLOWERING}

Duke of York. Most magnificent of the variegated Cannas, Bears great bunches of immense flowers; color a beautiful, rich, deep crimson, with a throat of curiously mottled creamy white, and each petal exquisitely edged with an irregular border of fine gold. Height 5 feet

Madam Crozy. Vermilion with golden border. One of the most popular Cannas, $3 \frac{1}{2}$ feet.

Wyoming. Giant-Flowering Purple Foliage Canna. This is a most majestic Canna. Blossoms orange colored, true orchid-shaped with large rounded petals that flap and flutter in the breeze like glistening flags. 7 feet.

Gladioflora. Remarkable on account of the unusual shape of its flowers, which look like a Gladiolus; color crimson, changing to carmine-rose, with an irregular edge of gold. $61 / 2$ feet.

\section{BRONZE-FOLIAGED}

Musaefolia. This is the finest foliage Canna yet seen, with enormous musa-like leaves $3 \times 5$ feet high, of a dark bronze-tinged green, the edges of the leaves being beautifully banded with bronze-purple. Attains a height of 8 feet.

King Humbert. Flowers are a brilliant orange scarlet with bright red shadings, the individual bloom measuring 6 inches across. Foliage a rich reddish bronze, with lighter shadings. 5 feet.

Robusta. Probably the largest-growing Canna in cultivation. If planted in rich, deep soil it will attain 7 to 9 feet in height. Foliage very large and broad, color rich metallic bronze-green. Height $6 \mathrm{feet}$

Each 15 cts. By mail add 10 ets. postpaid. $\$ 1.25$ per dozen; $\$ 5.00$ per 100 .

\section{ORNAMENTAL GRASSES}

\section{ANNUAL}

AGROSTIS. Hardy annual, light and graceful, especially for $\mathbf{P k t}$.

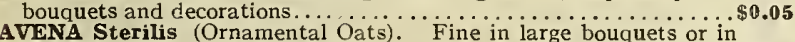
AVENA Sterilis (Ornamental Oats). Fine in large bouquets or in .05

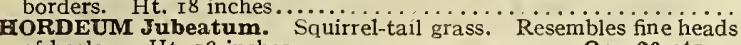
of barley. Ht. I8 inches................... 20 cts.. BRIZA Gracilis (Quaking grass), Ht. I foot....... Oz., $30 \mathrm{cts} . .$. BROMUS Brizaformus. Large drooping panicles. Very fine. COIX Lacrima (Job's Tears). Ht. I8 inches........ Oz., 25 cts.. ERAGROSTIS Elegans (Love grass). Very graceful. Ht. 15 inches. Oz., 25 cts. PENNISETUM Longystylum. Graceful drooping heads of viole tint. Very beautiful. Ht. 2 feet................. 40 cts... ALL SORTS MIXED, ANNUAL ................, 30 cts... .05

\section{PERENNIAL}

ANDROPOGON Argenteum. Silvery foliage, fine for groups. Flst. Ht. 3 feet..................... 50 ets. $\$ 0.10$ EULALIA JAPONICA. Long graceful leaves of a dark green, striped cream white..................... oz., 25 ets.

ERYANTHUS Ravenna. Closely resembles the well known Pampas grass. Fine rushlike foliage and silvery plumes. Highly ornamental for lawn. Sown early will bloom first season............. green, gracefully recurved. Panicles appear late July. Silvery green, grante violet purple and waving in the sunlight are of picturesque beauty. Ht 3 to 4 feet........1/2 oz., 20 cts. .. STIPA Lagascea (Feathergrass). Long nartow, silvery white feathery plumes........................ 40 ets. 10

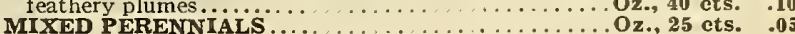




\section{JAPAN BAMBOO STAKES}

Do not decay like Southern Cane stakes or wooden stakes, but last a long time. Invaluable for staking Gladioli, Lilies, Herbaceous plant3. We do not prepay on Bamboo

NATURAL COLOR

$25 \quad 50 \quad 100 \quad 1000$

$6 \mathrm{ft}$. long, heary pencil thickness.........\$0.50 $\$ \mathbf{\$ 0 . 8 5} \$ \mathbf{\$ 1 . 5 0} \$ \mathbf{\$ 1 2 . 6 0}$ $3 \mathrm{ft}$. heary pencil thickness............. $.35 \quad .60 \quad 1.10$

\section{GREEN DYED INVISIBLE BAMBOO}

\begin{tabular}{|c|c|c|c|c|}
\hline & 25 & 50 & IOO & 100 \\
\hline ng, heavy pen & 0.30 & $\$ 0.50$ & $\$ 0.75$ & $\$ 1.7$ \\
\hline ong, heary pencil thickness... & .40 & .75 & 1.25 & 2.75 \\
\hline long, heary pencil thickness............ & .50 & .85 & 1.50 & \\
\hline t. long, heavy pencil thickness... & .60 & 1.00 & 1.75 & \\
\hline
\end{tabular}

\section{VERY HEAVY STAKES}

Natural color, suitable for Dahlias, Tomatoes; to support young trees, tall plants. Also for building Fancy Bridges, Kiosks, Screens in Japanese Gardens, or where Oriental effects are desired.

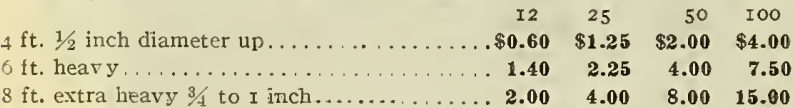

WOODEN LABELS FOR POTS

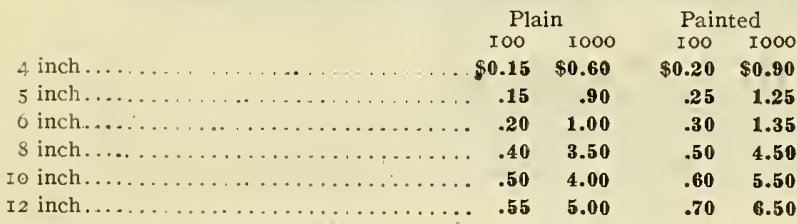

Penc:1s to use on labels, indelible, each is cents.

\section{FERTILIZERS}

BONE MEAL. A finely pulverized form of ground bone specially prepared for flower culture, top-dressing of lawns, and for potted house plants, etc. Lb., 10 ets.; 10 lbs., 50 ets.; 100 lbs., $\$ 4.00$.

BOWKERS' AMMONIATED FOOD FOR PLANTS. Specially prepered for house plants; clean, free from all offensive odor and great for the splendid flowering and luxuriant growth of plants. Directions on each package. Small size, 15 cts.; large pkt., 25 cts.

EXCELSIOR PLANT FOOD. Is a complete and odorless fertilizer for house plants, lawns, vegetables, etc. Sold in powdered form and used by dissolving in water. $3 / 2 \mathrm{lb}$. pkg., making $80 \mathrm{pts.,}$ ouly 35 cts. postpaid; 1 b., 160 pts., 60 ets., postpaid.

NITRATE OF SODA. A grand fertilizer for all and any crop. Very rapid in action, it hastens and matures crops fully two weeks earlier. Being quickly soluble it must not be applied until the plants are well above ground when 200 to $300 \mathrm{lbs}$. mixed with land plaster or wood ashes is sufficient for one acre. Nitrate of Soda does not exhaust the soil. $5 \mathbf{l b}$. pkgs., 75 cts.; 10 lbs., $\$ 1.25 ; 25$ lbs., $\$ 4.50$.

PURE PULVERIZED SHEEP MANURE. The most natural nutritious manure. Immediate and lasting in its effects. Excellent for mi xing with the soil in potting plants or sowing seeds. For vegetables, rapid stead $y$ growth and earlier maturity is gained. For field and garden crops, I to 2 tons per acre. Half the quantity before plowing, the balance before harrowing. Packages 5 lbs., 30 ets.; 100 lbs., \$2.75.

\section{INSECTICIDES}

APHINE. Most effective against green, black or white fly, red spider mealy bug, brown or white scale. Aphine is unexcelled as a wash for decorative foliage plants, and cabbage worms. $1 / 2$ pt., 40 cts.; pt., 65 ets.; qt., \$1.00.
FUNGINE, Infallible remedy for mildew, rust, wilt, and other blights affecting plant life, vegetables, etc. Equally efficient under glass as out-of-doors: I gallon makes 50 gallons of spray. $1 / 2$ pt., 30 cts.; pt., 50 cts.; qt., $\$ 1.00 ;$ gal., $\$ 3.00$

HELLEBORE POWDER. One ounce to 5 gallons of water. For the destruction of slugs, worms, caterpillars. Per lb. box, 75 cts.; 2 lbs., $\$ 1.25$.

KEROSENE EMULSION. Can be used by simply adding water. One part emulsion to 25 or 50 parts of water. For scale on trees, cabbage worms, melon louse, rose bugs, green fly, and lice of all sorts, and sucking insects whether on plants or animals. Per pt., 35 cts.; qt., 50 cts.: gal., $\$ 1.50$.

LEMON OIL. Non-poisonous. Destructive to all insects and soft scale. Apply as spray or wash. It has a very agreeable odor. $1 / 2 \mathbf{p t}$., $25 \mathrm{cts}$.; pt., 50 ets.; qt., 75 ets.; gal., $\$ 2.50$.

NICOTEEN. Extract of Tobacco. A safe and economical remedy and perfectly safe in fumigating greenhouses and conservatories. A scant tablespoonful to one pint of water placed in a pan. Place a hot iron in the solution which will cause sufficient vapor to fumigate a floor space of 500 square feet. Per pt. bottle, $\$ 1.50 ; 2$ oz. bottle, 40 ets.

NICO FUME. Tobacco paper insecticide. This is the strongest tobacco paper on the market; does not injure blooms, and furnishes the easies method for fumigation ever devised. Tin can of 24 sheets, $\$ 1.00$.

SULPHO TOBACCO SOAP. A safe and effective exterminator of al insect life on plants. 2 oz. cake, 10 cts.; 8 ozs., 20 ets.

SULPHUR, FLOWER OF. Lb., 15 cts.; 10 lbs., \$1.00.

VERMINE is a soil sterilizer and vermicide which will destroy insects such as cutworms, eelworms, maggots, wireworms, grubs. Lants, etc. $1 / 2$ pt., 40 ets.; pt., 65 cts.; qt., $\$ 1.00$.

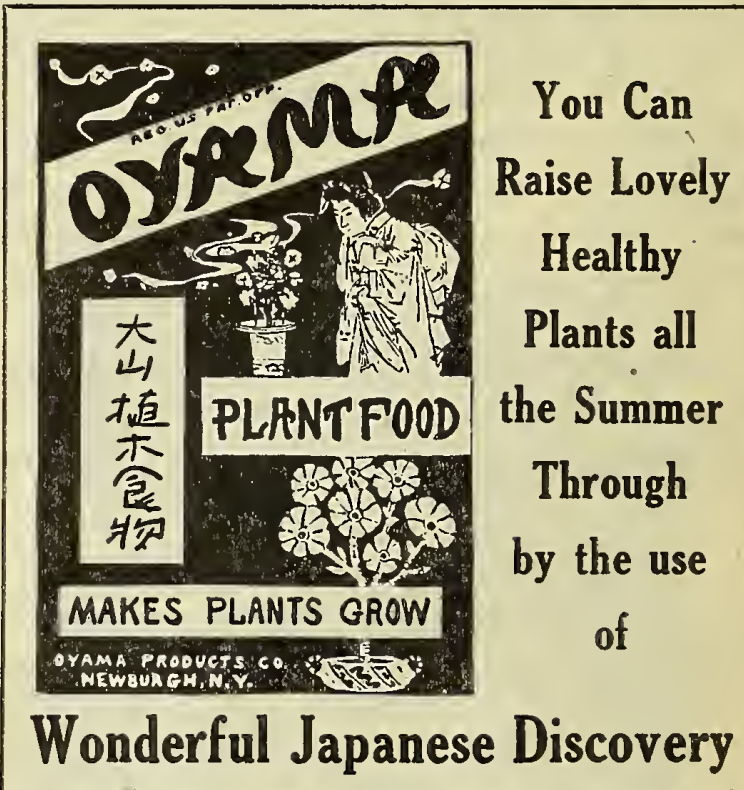

OYAMA is clean, odorless, and highly concentrated. It can be used in liquid form on all kinds of plants, shrubs, roses, bulbs, berries fruit, lawn, flower, and vegetable gardens and

\section{PRODUCES LARGE VEGETABLES AND BEAUTIFUL FLOWERS VERY EARLY}

YOUR FRIENDS WILL MARVEL AT YOUR SUCCESS., Fine for bulbs - will make them bloom freely and in advance of others. All who have plants should use this wonderful fertilizer. We cannot recommend it too highly. Full directions with each box.

$\begin{array}{clcc}\text { Price } & \text { Trial....... Size } & 15 \mathrm{c} & \begin{array}{c}\text { Order } \\ \text { a box } \\ \text { to-day }\end{array} \\ \text { postpaid } & \begin{array}{c}\text { House Plant } \\ \text { Garden........ }\end{array} & \$ 1.10 & \end{array}$




\section{EASTER THIS YEAR OF 1918 FALLS ON MARCH 31}

What GIFT in more welcome to your friends than FLOWERS?

What speaks to them with sweeter voices than these?

What could be more charming, expressing your affection better than flowers raised by YOURSELF?

You can do this by planting our

\section{MAGIC LILY OF THE VALLEY}

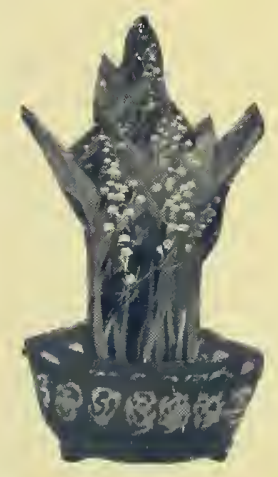

IN OUR SPECIALLY PREPARED MOSS FIBER

The accompanying picture is taken from a PHOTO showing the Valley in bloom eighteen days from time of planting. Purest white, deliciously fragrant, the lovely bells ring out joyous Easter Greetings to your friends.

To yourself or others, the watching of the wonderful budding and blossoming of these lovely flowers is a revelation. Thousands of homes have been cheered; thousands of INVALIDS and SHUT-INS have been made happy thereby.

Florist's Flowers have but a short life. Lily of the Valley planted in the Moss Fiber will blossom for many days. We have hundreds of letters praising these charming blossoms and their method of growth.

We send postpaid:
6 pips.
$\$ 0.50$
12 pips................. .95
20 pips.
$\$ 1.50$ pips, and FUI almost impossible

Order Early. Stock is always scarce

\section{A MILLION COMFORT BAGS THE BOYS GO MARGHING ON \\ What does the soldier want most after water for comfort? \\ THINK! Something to relieve his tired feet. We have it here in}

\section{The Japanese Yama-Yuri Foot Powder}

used by the little brown men when marching. A genuine FOOT-EASE. Affords instant comfort and relief for tired, aching and sweaty feet. HEALING, ANTISEPTIC. Send your boy a tin of REAL COMFORT. Should be in every comfort bag sent out.

Price, good-sized tin, shaker top, 25 cents. Sample 10 cents. Send for it now.

We are agents for all the YAMA-YURI Spesialties. Send for price list.

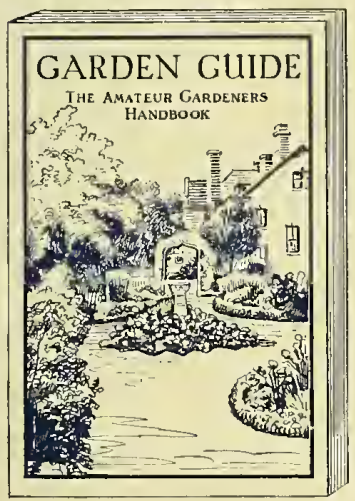

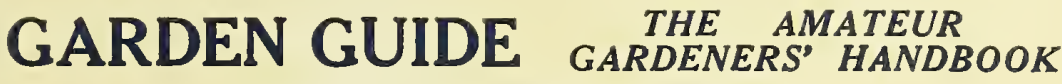

"Food will Win the War-Produce it!"

Written by gardening experts expressly for the amateur and non-professional. Covers in detail the growing of Tomatoes, Peas, Beans, Cabbage, Celery, Beets, Corn, Onions and all chief vegetables; growing fruits for the small garden or orchard, Apples, Peaches, Grapes, Berries, etc.; ornamental trees, hedges, gardens and plantings of all kinds; constructing hot beds, cold frames, seed boxes, etc.; how to prune and propagate, control insect pests and diseases; all about soils, fertilizers, spraying, tools, etc. 1001 other live, up-to-date gardening facts, simply explained - easily followed. It gives the How, the When and the Wherefrom purchase of seeds and tools to reaping the harvest. Every book purchased sells another. 150 teaching illustrations; 256 pages. Cover in four colors. Price: Paper cover, 50 cts. (by mail, 55 cts.): cloth cover, 75 cts. (by mail, 85 ets.). 


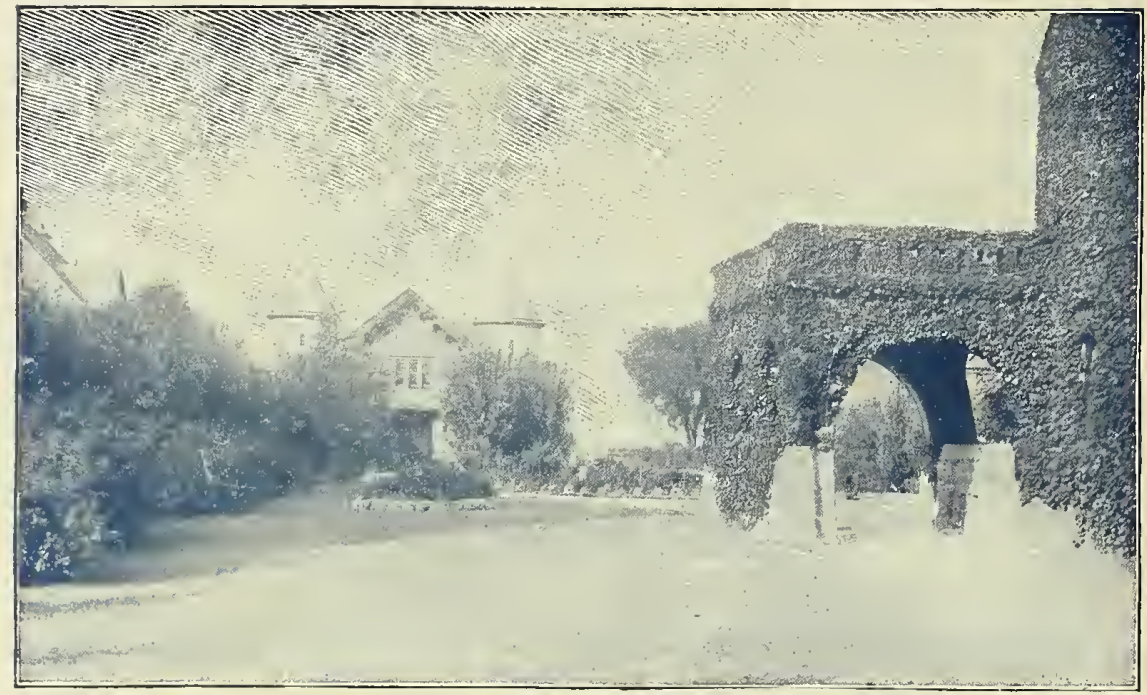

A Beautiful Lawn

\section{WATERING THE LAWN}

Water must be always applied in a manner that the moisture reaches the roots, mere surface sprinkling is of no use. In warm weather water
only in the early morning or after sundown. A good thing is, to let lawn sprinklers run for awhile on one spot, until thoroughly saturated, then remove to next one until the whole lawn has had a good soaking which will last better than a slight application of water several times.

\section{WEEDS}

One of the most frequent weeds in the lawn is the Dandelion. These have long taproots and must be taken out thoroughly to keep out. A good tool is an asparagus knife with a long blade, which reaches to bot tom of root. Plantains also infest lawns. They can be easily drawn out with the hand. Wherever weeds leave an empty spot sprinkle a little fresh grass seed and press down hard. It will soon obliterate with fresh growth. No matter what tools are offered for the extirpation of weeds nothing takes the place of conscientious hand weeding.

\section{BERGER'S TIP TOP LAWN GRASS}

(25 lbs. to the Bushel)

Of highest purity and greatest vitality. All varieties carefully proportioned so as to maintain a bright rich green color from first appearance to late frosts. One pound will sow a plot $20 \times 20 \mathrm{ft}$.; 80 pounds will sow an acre.

One lb.,40 cts.; 5 lbs., $\$ 1.75 ; 10$ lbs., $\$ 3.25 ; 25$ lbs., $\$ 8.00 ; 100$ lbs., $\$ 30.00$.

Price includes delivery.

\section{OUR VELVET SOD LAWN GRASS}

(22 lbs. to the Bushel)

This is a very fine grade of Grass seed. Composed of finest recleaned grasses free from weeds, chaff and foreign matter. In comparing prices always note the weight of the seed. Cheap Lawn grass seeds will weigh from 14 to $16 \mathrm{lbs}$. to the bushel, owing to the large mixture of coarse matrom 14

One lb., 35 cts.; 5 lbs., $\$ 3.25 ; 10$ lbs., $\$ 5.50 ; 25$ lbs., $\$ 7.50$; 100 lbs., $\$ 28.00$

\section{SHADY PLACE LAWN GRASS SEEDS}

No grass will grow under Pine trees.

If greenery is wanted under pine or conifer trees, small creeping plants must take the place of the grassy sod. Bare unsightly spots will, however, appear in places around evergreens, etc., where the sun does not penetrate. This can be remedied by using this seed, which is composed of varieties of grasses thriving in shady spots.

One lb., $40 \mathrm{cts}$; one bu. of 20 lbs., $\$ 7.00$, including delivery.

\section{TERRACE SOD GRASS}

Special mixture of grasses which cannot be washed out by rains and which produce a fine velvety green surface. The roots of all these sorts are especially strong and deep.

One lb., postpaid, 50 cts.; 5 lbs., postpaid, $\$ 2.25$; bu. of 20 lbs., not prepaid, $\$ 6.75$. fertilized in fall it will not need it in spring II not, the best dressing for a lawn in spring is one of Bonemeal or Canadian hardwood ashes. Put on thick enough to give the grass a grayish appearance after the application. Nitrate of Soda applied cautiously is the best remedy to make the lawn appear especially thrifty and, of water and sprinkle the grass. The effect will show in a very short time.

\section{GRASS FOR THE SEASHORE}

Mixture of fine grasses thriving in sea air and heavy sea fogs. Sow as early as possible in the spring. Use $100 \mathrm{lbs}$. to the acre. One lb. for plots 200 square feet.

One lb., post paid, 50 cts.; 5 lbs., post paid, $\$ 2.25$; 20 lbs., not prepaid, $\$ 7.00$.

\section{LAWNGRASS FOR THE SOUTH}

A fine mixture of grasses best adapted to withstand great heat and drought

One ib., postpaid, 40 cts.; 5 lbs., postpaid, $\$ 1.75$; 20 lbs., not prepaid, $\$ 5.00$.

\section{CLOVERS}

\section{WHITE CLOVER}

Mixed with other grasses is very desirable, on account of its creeping tems, for lawn purposes, a binder; and of considerable value for perma. nent pastures. Crop short.

Extra fancy seed, 1 lb., 50 cts.; (by mail 58 cts.); $10 \mathrm{lbs}$., $\$ 4.75$; bu. $(60$ lbs.), $\$ 27.50 ; 100$ lbs., $\$ 45.00$.

Choice seed, clean, but not as bright as above, 1 lb., 45 cts.; (by mail, 53 cts.); 10 lbs., $\$ 4.25$; bu. (60 lbs.); $\$ 24.50$; 100 lbs., $\$ 40.00$.

\section{CRIMSON CLOVER}

Annual crop much used in the East and South for soiling or pasture. It is being tried in the North.

One lb., 20 cts. (by mail 28 cts.); 10 lbs., $\$ 1.50$; bu. $(60$ lbs., $\$ 6.50$; 100 lbs., $\$ 10.00$.

\section{FANCY MEDIUM RED CLOVER}

Clover seed this year is very high, and good qualities are scarce, due to the long rainy summer. Much seed is colored, weedy, and of poor germination. Sow the cleanest, highest germination seed you can find. If unable to determine yourself what is germination seed you can find. If unable to determine yourself what is good, send samples of what you are offered Agriculture, Seed Laboratory at W ar the United States Department of Agriculture, Seed Laboratory, at $W$ ashington for analysis. Our seed is the purest and highest high testing seed we can buy and we are at all times
willing to submit samples from identical lots of seed. Sow 8 to 10 pounds

One lb., 25 cts. (by mail, 33 cts.); 10 lbs., $\$ 2.35$; bu., $\$ 11.25$; 100 lbs., $\$ 18.50$. Choice grades for less money. Write for samples.

\section{MAMMOTH RED CLOVER, FANCY SEED}

Grows larger than the medium, does well on light thin lands. Price, January 20 th, always subject to market changes.

One lb., 35 cts. (by mail, 33 cts.); 10 lbs., $\$ 2.35$; bu., $\$ 11.25 ; 100$ lbs., $\$ 18.50$.

All grass and clover seed prices subject to change with market prices. 